\title{
Biochemical and functional differences of chromatin assembled replication-coupled or independent in Xenopus laevis egg extracts
}

\author{
Dissertation \\ for the award of the degree \\ “Doctor rerum naturalium" (Dr. rer. nat.) \\ Division of Mathematics and Natural Sciences \\ of the Georg-August-Universität Göttingen
}

submitted by

Alexandra Stützer

born in

Heiligenstadt, Germany

Göttingen, 2011 
Thesis Committee Members:

Dr. Wolfgang Fischle ( $1^{\text {st }}$ reviewer), Research Group Chromatin Biochemistry Max Planck Institute for Biophysical Chemistry, Göttingen

Prof. Dr. Reinhard Lührmann (2 ${ }^{\text {nd }}$ reviewer), Department of Cellular Biochemistry Max Planck Institute for Biophysical Chemistry, Göttingen

Prof. Dr. Tomas Pieler, Department of Developmental Biochemistry Georg-August-University Göttingen

Date of the oral examination: June 7, 2011 


\section{Affidavit}

I affirm that the presented thesis "Biochemical and functional differences of chromatin assembled replication-coupled or independent in Xenopus laevis egg extracts" has been written independently and with no other sources and aids than quoted.

Göttingen, April 30, 2011

Alexandra Stützer 



\section{Acknowledgements}

First and foremost, I want to thank my supervisor Dr. Wolfgang Fischle for giving me the opportunity to work on this interesting project. I am grateful for his constant support, constructive criticism and guidance over the last years. His 'lets do it' virtue has always been a source of motivation for me.

I want to thank my thesis committee members Prof. Dr. Reinhard Lührmann and Prof. Dr. Tomas Pieler for their interest in my project and the fruitful discussions and interesting suggestions during my committee meetings.

I am indebted to Dr. Annette Borchers and all group members from the Pieler department for putting up notes for me every time I needed some frog eggs. Without their support there wouldn't have been any chromatin assembly experiment.

I want to thank the GGNB for the constant support, informative lectures, highly supportive method courses as well as inspiring retreats.

I am grateful to Prof. Dr. Henning Urlaub and his group for their excellent mass spectrometry work, for helpful advices and explanations. In particular, I want to thank Miroslav Nikolov for his enthusiasm for the chromatin pulldown project as well as for the analyses of my chromatin samples.

I also want to thank Prof. Dr. Axel Imhof for his excellent analyses on histone modifications.

I am thankful to Thomas Conrad and Hossein Kohansal for giving me HeLa cell nuclear extract. Many thanks go to Prof. Dr. Geneviève Almouzni and Prof. Dr. Stefan Dimitrov for sharing Xenopus reagents with me. I am also thankful to Simon Elsässer for providing me with the H3.3 expression construct and Prof. Dr. Daniela Rhodes for the 601 templates.

I am thankful to Claudia Fahlbusch, Winfried Lendeckel, Ina Herfort, Franziska Paap, Haxia Ding, Jennifer Bals and Natalie Klytta for running daily lab business. Special 
thanks go to Winfried Lendeckel for purifying considerable amounts of histone proteins for me.

I want to thank all lab members of the Fischle group for the pleasant time throughout my thesis, for the constant help and advice. Many thanks go to Nils for his efforts to produce nice AFM images. I am especially grateful to Kathy and Franzi for their friendship and the valuable hours spend outside of the lab.

I thank all people from the RV Bovenden for giving me good reasons to leave the lab and the opportunity to clear my head.

Lastly, I owe my gratitude to my family. In particular I want to thank my parents Birgit and Heinrich Stützer and my sister Dr. Christin Stützer for constantly supporting and encouraging me to go all the way and for cheering me up during difficult times. 


\section{Table of contents}

$\begin{array}{ll}\text { List of figures } & \text { XI }\end{array}$

$\begin{array}{lll}\text { List of tables } & \text { XII }\end{array}$

$\begin{array}{lll}\text { Abbreviations } & \text { XIII }\end{array}$

1 INTRODUCTION

$\begin{array}{lr}\text { 1.1. Chromatin structure } & 1\end{array}$

1.1.1. The nucleosomal core particle $\quad 1$

1.1.2. Folding of chromatin into higher-order structures 3

$\begin{array}{ll}\text { 1.1.3. Heterogeneity of chromatin within the nucleus } & 3\end{array}$

$\begin{array}{ll}\text { 1.2. Modulation of chromatin structure } & 5\end{array}$

$\begin{array}{ll}\text { 1.2.1. Histone variants } & 5\end{array}$

1.2.2. Posttranslational modifications $\quad 6$

$\begin{array}{lr}\text { 1.2.2.1. PR-Set7 - a monomethyltransferase } & 8\end{array}$

$\begin{array}{ll}\text { 1.2.2.2. Stability of histone modifications } & 8\end{array}$

1.2.3. Functional consequences of histone marks 9

1.2.3.1. H4K20 methylation - a multi-faceted histone modification $\quad 10$

$\begin{array}{ll}\text { 1.2.3.2. Molecular read-out of histone modifications } & 10\end{array}$

1.2.4. The impact of remodeling machineries on chromatin structure 11

1.3. Chromatin assembly $r$

1.3.1. Histone chaperones $\quad 12$

1.3.2. Experimental approaches towards reconstitution of functional chromatin states 14

$\begin{array}{ll}\text { 1.3.2.1. Recombinant chromatin } & 14\end{array}$

$\begin{array}{ll}\text { 1.3.2.2. SV40 replication system } & 15\end{array}$

1.3.2.3. Cell-free assembly systems using extracts from Drosophila and Xenopus 15

$\begin{array}{ll}\text { 1.3.3. Assembly pathways } & 16\end{array}$

$\begin{array}{ll}\text { 1.3.3.1. Replication-coupled assembly } & 17\end{array}$

$\begin{array}{ll}\text { 1.3.3.2. Replication-independent assembly } & 18\end{array}$

1.3.3.3. Why does the cell need more than one chromatin assembly pathway? 19

$\begin{array}{ll}\text { 1.4. Objectives of the presented thesis } & 21\end{array}$

2 MATERIAL AND METHODS $\quad 22$

2.1. Material and reagents $\quad 22$

\begin{tabular}{ll} 
2.1.1. & Laboratory equipment \\
\hline
\end{tabular}

$\begin{array}{ll}\text { 2.1.2. Chemicals } & 23\end{array}$

2.1.3. Radiochemicals 24

$\begin{array}{ll}\text { 2.1.4. Commonly used buffers and solutions } & 25\end{array}$

2.1.5. Commercial kits 26

$\begin{array}{ll}\text { 2.1.6. Consumables and chromatographic material } & 27\end{array}$

$\begin{array}{ll}\text { 2.1.7. Antisera and monoclonal antibodies } & 28\end{array}$

\begin{tabular}{ll} 
2.1.8. & Enzymes, proteins and inhibitors \\
\hline
\end{tabular}

\begin{tabular}{ll} 
2.1.9. & Oligonucleotides \\
\hline
\end{tabular}

$\begin{array}{ll}\text { 2.1.10. Plasmids } & 30\end{array}$

$\begin{array}{ll}\text { 2.1.11. Bacterial strains and cell lines } & 31\end{array}$

2.2. Molecular biology methods $\quad 32$

2.2.1. Analysis of nucleic acids $\quad 32$

2.2.1.1. Concentration determination of nucleic acids $\quad 32$

2.2.1.2. Agarose gel electrophoresis $\quad 32$ 
2.2.1.3. Native polyacrylamide gel electrophoresis of DNA (Native PAGE) 32

2.2.1.4. Denaturing polyacrylamide gel electrophoresis of RNA (Urea-PAGE) 32

2.2.2. General cloning procedures

$\begin{array}{ll}\text { 2.2.2.1. cDNA sequences } & 33\end{array}$

2.2.2.2. Polymerase chain reaction (PCR) $\quad 35$

2.2.2.3. Restriction digest and ligation of DNA 35

2.2.2.4. Transformation of competent bacteria $\quad 36$

2.2.2.5. Sequence analysis of cloned constructs 36

2.2.3. Generation of the $\mathrm{pBS}-\mathrm{G}_{5} \mathrm{ML}_{\text {phagemid }} \quad 36$

\begin{tabular}{ll} 
2.2.4. & Generation of expression constructs \\
\hline
\end{tabular}

$\begin{array}{ll}\text { 2.2.4.1. pET3a expression constructs for histone proteins } & 38\end{array}$

$\begin{array}{lll}\text { 2.2.5. } & \text { Preparation of DNA templates for chromatin assembly } & 38\end{array}$

$\begin{array}{ll}\text { 2.2.5.1. Large scale preparation of double-stranded (ds) DNA } & 38\end{array}$

2.2.5.2. Preparation of M13K07 helper phage stock $\quad 39$

2.2.5.3. Preparation of single-stranded (ss) DNA using M13K07 helper phage 39

2.2.5.4. Preparation of mono-/oligonucleosomal DNA templates $\quad 40$

$\begin{array}{ll}\text { 2.2.5.5. Preparation of scavenger DNA } & 41\end{array}$

2.3. Protein biochemistry methods $\quad 42$

2.3.1. Detection and analysis of proteins $\quad 42$

2.3.1.1. Concentration determination of proteins 42

2.3.1.2. Denaturing polyacrylamide gel electrophoresis of proteins (SDS-PAGE) 42

2.3.1.3. Coomassie staining of protein gels 43

2.3.1.4. Western blot analysis $\quad 43$

2.3.2. Recombinant proteins $\quad 44$

2.3.2.1. Purification of His-PR-Set7 44

2.3.2.2. Purification of GST-fusion proteins 44

2.3.2.3. Purification of recombinant histone proteins 45

2.3.2.4. Purification of His-tagged H3.3 46

2.3.2.5. Generation of $\mathrm{H} 3 \mathrm{~K} 4 \mathrm{me} 3$ histones by native protein ligation 47

2.3.2.6. Expression of HIRA in rabbit reticulocyte lysate 47

$\begin{array}{ll}\text { 2.3.2.7. GST-pulldown assays } & 47\end{array}$

2.3.2.8. Immunoprecipiation of xHIRA from high-speed egg extracts 48

2.3.2.9. Histone methyltransferase (HMT) assay 48

$\begin{array}{ll}\text { 2.3.3. Recombinant chromatin } & 48\end{array}$

2.3.3.1. Assembly of octamers and tetramers $\quad 48$

2.3.3.2. Chromatin reconstitution by salt dialysis 49

2.4. Xenopus-based methods $\quad 49$

2.4.1. Preparation of frog egg extracts 49

$\begin{array}{ll}\text { 2.4.2. Standard chromatin assembly in HSE } & 51\end{array}$

2.4.2.1. Using circular DNA templates $\quad 51$

2.4.2.2. Using demembranated sperm chromatin $\quad 51$

2.4.3. Precipitation of HSE-derived chromatin with $\mathrm{MnCl}_{2} \quad 51$

2.4.4. Monitoring of second strand synthesis $\quad 52$

2.4.5. Topological assays of HSE-derived chromatin $\quad 52$

2.4.5.1. Supercoiling assay $\quad 52$

2.4.5.2. MNase digestion $\quad 53$

2.4.6. Purification of chromatin by sucrose density gradient centrifugation 53

2.4.6.1. Identification of chromatin-containing fractions $\quad 54$

2.4.7. Transcriptional analysis of chromatin $\quad 54$

2.4.7.1. Transcription assay $\quad 54$

2.4.7.2. Preparation of transcription-competent HeLa nuclear extract 55

2.4.7.3. Autoradiography and Phosphor Imager analysis 55

$\begin{array}{ll}\text { 2.5. Special methods } & 56\end{array}$

2.5.1. Mass spectrometry of chromatin-associated proteins and histone modifications 56

2.5.2. Atomic force microscopy (AFM) of chromatin 56 
3.1. Replication-coupled and replication-independent assembly in a cell-free system

3.1.1. Establishment of a chromatin assembly system in Xenopus laevis egg extracts

3.1.2. Construction of DNA templates suitable for replication-coupled and replicationindependent chromatin assembly

3.1.3. Chromatin can be retrieved from the egg extract by precipitation

3.2. Topological and structural characterization of chromatin species

3.2.1. RI and RC assembled chromatin have comparable topological properties

3.2.2. Different hydrodynamic behavior of chromatin species

3.2.3. RC and RI assembled chromatin species form discrete structures

3.3. Biochemical characterization of chromatin

3.3.1. Identification of chromatin-associated proteins

3.3.1.1. Histone proteins

3.3.1.2. Transcription factors/DNA binding proteins

3.3.1.3. Remodeling complexes and histone chaperones

3.3.1.4. Chromatin modifying enzymes

3.3.2. Histone variants are not equally distributed - Incorporation of H3.3 and H2A.Z 75

3.3.3. Methylation and acetylation patterns of RI or RC assembled chromatin 80

3.3.3.1. Methylation patterns

3.3.3.2. Methylation patterns of decondensed sperm chromatin

3.3.3.3. Acetylation patterns

3.3.3.4. Determination of acetylation and methylation patterns by mass spectrometry

3.3.4. Methylation of $\mathrm{H} 3$ and $\mathrm{H} 4$ as a result of RI chromatin assembly

3.4. Involvement of non-histone proteins in RI and RC assembly

3.4.1. PR-Set7 actively methylates chromatin independent of H3.3 and H3K4me $\quad 91$

3.4.2. PR-Set7 does not interact with HIRA 94

3.4.3. HIRA associates with an H3K4 methyltransferase 96

3.5. Functional consequences of RI and RC assembly pathways 98

3.5.1. The high-speed egg extract cannot mediate transcription 98

3.5.2. RI assembly leads to transcriptional active chromatin 100

3.5.3. Transcription is dependent on methylation of chromatin 102

\section{DISCUSSION 105}

4.1. Assembly pathways create distinct chromatin structures $\quad 105$

4.1.1. Influence of histone acetylation and methylation on chromatin structure 107

4.2. Active histone methylations as a result of RI chromatin assembly 108

4.2.1. Cell cycle dynamics of H4K20 monomethylation 108

4.2.2. Regulation of H4K20me1 and PR-Set7 activity 110

4.2.3. H3K4me and H4K20me1 as major determinants of transcriptional activity 111

\subsection{Histone H3.3 marks RI assembly whereas H2A variants are incorporated} in both pathways

4.3.1. Histone variants can be incorporated during both pathways 112

$\begin{array}{ll}\text { 4.3.2. Combinations of histone variants and unique proteins potentially change } & 114 \\ \text { chromatin stability }\end{array}$

4.4. Physiological roles of chromatin assembly pathways 115

4.4.1. Implications of replication-independent assembly in fertilization 115

4.4.2. Is all newly replicated chromatin silenced? 116

4.4.3. HIRA and RI assembly as the key players in resetting transcriptional competency 117 
5 SUMMARY AND CONCLUSIONS 119

6 REFERENCES 120

$\begin{array}{llr}7 & \text { APPENDIX } & 129\end{array}$ 


\section{List of figures}

Figure 1.1 | Structure of the nucleosomal core particle. ................................................................ 2

Figure 1.2 | Hierarchical levels of chromatin condensation. ................................................................... 4

Figure 1.3 | Major sites of histone modifications on human core histones. ........................................... 7

Figure 1.4 | Molecular read-out of histone modifications. ........................................................... 10

Figure 1.5 | Chromatin assembly pathways and histone replacement. ................................................ 19

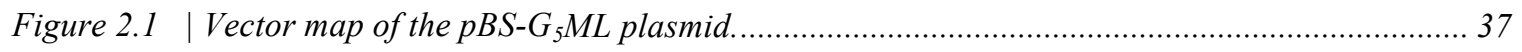

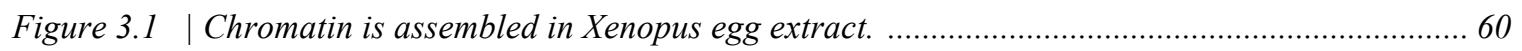

Figure 3.2 | Preparation of double-stranded and single-stranded DNA templates. ................................ 62

Figure 3.3 | Extract assembled chromatin is precipitated by divalent cations. .................................... 64

Figure 3.4 | Replication-coupled and replication-independent chromatin assembly results in

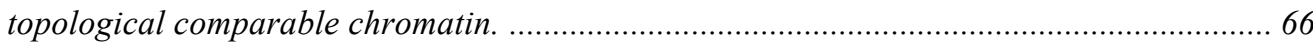

Figure 3.5 | Replication-coupled chromatin assembly visualized by incorporation of $\left[\alpha-{ }^{32} P\right] d A T P . \ldots . .67$

Figure 3.6 | DNA and Chromatin species differ in their hydrodynamic behavior and EtBr

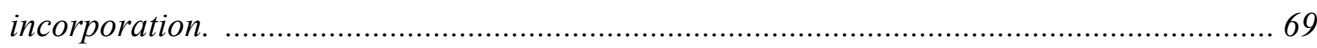

Figure 3.7 | AFM analysis of chromatin species. .............................................................................. 70

Figure 3.8 | Mass spectrometry analysis of chromatin associated proteins. . ....................................... 72

Figure 3.9 | Mass spectrometry reveals incorporation of H3.3 into RI assembled chromatin. ................ 76

Figure $3.10 \mid$ Histone variant H3.3 is specifically incorporated in a replication-independent fashion. ..... 78

Figure $3.11 \mid$ H2A.Z associates with both chromatin assembly pathways............................................ 79

Figure 3.12 | Chromatin assembled independent of replication is enriched in H3 and H4 methylation...... 81

Figure 3.13 | Histone H4 acetylation patterns change upon chromatin assembly on dsDNA....................83

Figure 3.14 | Identification of H4 methylation and acetylation sites by mass spectrometry..................... 85

Figure 3.15 | Identification of H3 methylation and acetylation sites by mass spectrometry......................8 87

Figure $3.16 \mid$ Histone methylation of sucrose gradient purified chromatin............................................ 88

Figure 3.17 | Time-resolved analysis of methylation patterns. ........................................................... 89

Figure 3.18 | PR-Set7 is not recruited by H3.3 to chromatin derived from dsDNA................................. 92

Figure 3.19 | PR-Set7 activity does not depend on H3K4me. ......................................................... 94

Figure $3.20 \mid$ PR-Set7 does not interact with HIRA. ......................................................................... 95

Figure 3.21 | HIRA associates with an H3K4 methyltransferase .......................................................... 97

Figure 3.22 | Egg extract is not capable of inducing transcription. ............................................... 100

Figure 3.23 | Chromatin assembled on ssDNA is refractory to transcription........................................ 101

Figure 3.24 | SAH inhibits methylation on dsDNA derived chromatin. .............................................. 103

Figure 3.25 | Methylation marks on dsDNA chromatin species enhance transcriptional activity............. 104

Figure 4.1 | Proposed model of transmission of repressive and active marks. ..................................... 118 


\section{List of tables}

Table 1.1 | Localization and function of canonical core histones and histone variants in mammalia. ........ 6

Table 1.2 | Common histone modifications and their biological function.............................................. 9

Table 1.3 | Histone chaperones and binding partners ........................................................................ 13

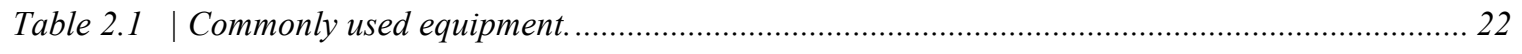

Table 2.2 | Chemicals used for preparation of buffers and media........................................................ 23

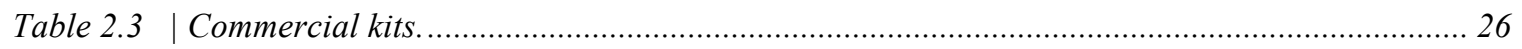

Table 2.4 | Consumables and chromatographic materials .................................................................. 27

Table 2.5 | Antisera and antibodies used for Western blotting and immunoprecipitation......................... 28

Table 2.6 | Commonly used enzymes, proteins and inhibitors.......................................................... 29

Table 2.7 | Plasmids used for cloning, heterologous protein expression and chromatin reconstitution. ... 30

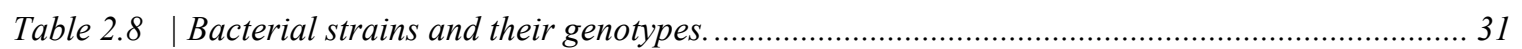

Table 2.9 | Overview of the cloned expression constructs ................................................................. 37

Table $2.10 \mid$ Molecular weights and extinction coefficients of proteins at given wavelength...................... 42

Table 4.1 | Summarized properties of chromatin species derived by replication-coupled (RC) or replication-independent (RI) chromatin assembly

Table 7.1 | Mascot result of dsDNA sample after substraction of proteins of mock and ssDNA samples......

Table 7.2 Mascot result of ssDNA sample after substraction of proteins present in mock and dsDNA. 131

Table 7.3 | Mascot result of proteins present in $d s D N A$ and ssDNA sample after substraction of mock. 131 
Abbreviations

\begin{tabular}{|c|c|c|c|}
\hline${ }^{3} \mathrm{H}-\mathrm{SAM}$ & $\begin{array}{l}\left.\text { S-[Methyl- }{ }^{3} \mathrm{H}\right] \text {-Adenosyl-L- } \\
\text { methionine } \\
\text { amino } \operatorname{acid}(\mathrm{s})\end{array}$ & $\begin{array}{l}\text { OD } \\
\text { PAGE }\end{array}$ & $\begin{array}{l}\text { optical density } \\
\text { polyacrylamide gel } \\
\text { electrophoresis }\end{array}$ \\
\hline bp & base pairs & PEG & polyethylene glycol \\
\hline $\mathrm{C}$ & Celsius & pfu & plaque forming units \\
\hline $\mathrm{Da}$ & Dalton $(\mathrm{g} / \mathrm{mol})$ & psi & pound per square inch \\
\hline $\mathrm{ddH}_{2} \mathrm{O}$ & $\begin{array}{l}\text { double distilled water } \\
\text { (sterilized) }\end{array}$ & $\begin{array}{l}\text { PTM } \\
\text { RC }\end{array}$ & $\begin{array}{l}\text { posttranslational modification } \\
\text { replication-coupled }\end{array}$ \\
\hline DNA & deoxyribonucleic acid & RI & replication-independent \\
\hline DNase & deoxyribonuclease & RNA & ribonucleic acid \\
\hline ds & double-stranded & RNase & ribonuclease \\
\hline E. coli & Escherichia coli & RT & room temperature \\
\hline ELB & egg lysis buffer & $\mathrm{s}$ & second(s) \\
\hline $\mathrm{g}$ & gram or gravity force & S. cerevisiae & Saccharomyces cerevisiae \\
\hline GST & glutathione S-transferase & S. pombe & Schizosaccharomyces pombe \\
\hline $\mathrm{h}$ & hour(s) & $\mathrm{SAH}$ & S-(5'-Adenosyl)-L- \\
\hline His-tag & histidine tag & & homocysteine \\
\hline HMT & histone methyltransferase & SAM & S-(5'-Adenosyl)-L-methionine \\
\hline HSE & high-speed extract & SDS & sodium dodecyl sulfate \\
\hline $\mathrm{k}$ & kilo & Ss & single-stranded \\
\hline 1 & liter & TEV & Tobacco etch virus \\
\hline LSE & low-speed extract & $\mathrm{U}$ & unit(s) \\
\hline $\mathrm{m}$ & milli or meter & UV & ultraviolet \\
\hline $\min$ & minute(s) & $\mathrm{v} / \mathrm{v}$ & volume per volume \\
\hline MMR & Marc's modified Ringer & $\mathrm{w} / \mathrm{v}$ & weight per volume \\
\hline MNase & Micrococcal nuclease & $X$. laevis & Xenopus laevis \\
\hline MW & molecular weight & $\alpha$ & anti-/antibody \\
\hline $\mathrm{n}$ & nano & $\mu$ & micro \\
\hline
\end{tabular}




\section{Introduction}

\section{Epigenetics}

The genetic information combined in the zygote after fertilization is transmitted to every single somatic cell within an organism. Still, the dramatic morphological and cytological differences that evolve during development cannot be attributed alone to information embedded in the DNA sequence. Conrad Waddington coined the term 'epigenetic landscape' in 1953 to describe this process of cellular differentiation during embryogenesis [1]. A more recent definition considers all mitotically and/or meiotically heritable changes in phenotype and gene expression that occur without an apparent change in DNA sequence as epigenetic [2]. Research over the last decades has shown that the molecular basis of these heritable changes lies within the specific properties of chromatin.

\subsection{Chromatin structure}

\subsubsection{The nucleosomal core particle}

In contrast to prokaryotes the large genomes of eukaryotes are stored inside a nuclear compartment. In order to fit the vast amounts of DNA into the cell nucleus, DNA is condensed by interaction with nuclear proteins into a highly compacted structure called chromatin. This entity of DNA and DNA-associated proteins comprises the physiological template for all DNA-related processes.

The fundamental packaging unit of chromatin is the nucleosomal core particle $[3,4]$. It consists of a $147 \mathrm{bp}$ stretch of DNA that is tightly wrapped around a disk-like protein complex made up of histone proteins. Histones are small basic proteins that fall into two main groups: core histones and linker histones. Core histone proteins are among the most conserved eukaryotic proteins and include $\mathrm{H} 3, \mathrm{H} 4, \mathrm{H} 2 \mathrm{~A}$ and $\mathrm{H} 2 \mathrm{~B}$. Each histone contains a common structural motif, named the histone fold, consisting of three alpha helices connected by two loops. This domain aids heterodimerization between core histones and DNA/histone interactions that are necessary for the formation of the nucleosomal core particle. A tetramer composed of two copies of $\mathrm{H} 3$ and $\mathrm{H} 4$ and two H2A-H2B dimers builds up a histone octamer. DNA is then wrapped around the octamer in a left-handed 1.65 times superhelical turn [5]. The N-terminal 
parts or tails of the core histones comprise long flexible protein chains, which protrude out from the nucleosomal core particle (Figure 1.1). Their accessibility and unstructured character predestines histone tails to function as signaling and docking platforms for binding proteins, whereas the histone fold domain mainly serves in mediating DNA condensation.

A

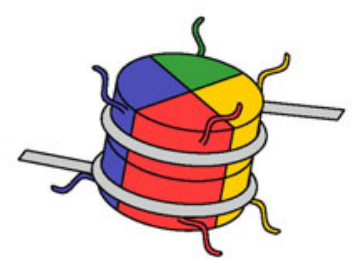

B

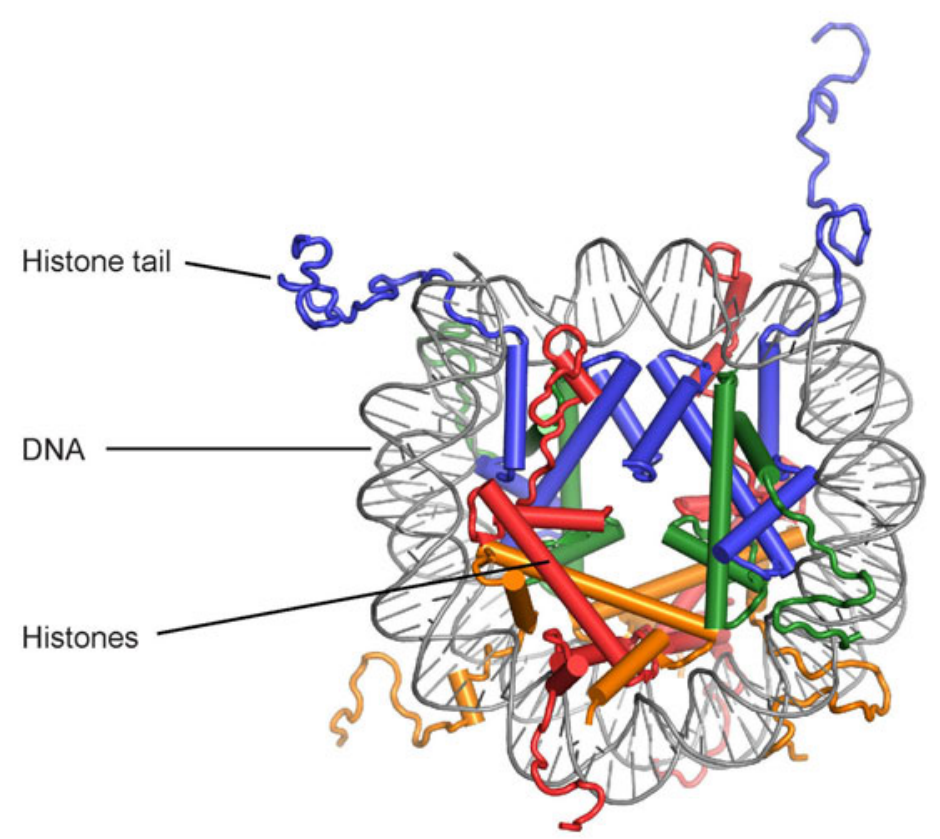

$\square \mathrm{H} 3 \quad \square \mathrm{H} 4 \quad \square \mathrm{H} 2 \mathrm{~A} \quad \square \mathrm{H} 2 \mathrm{~B}$

Figure 1.1 | Structure of the nucleosomal core particle. (A) Cartoon representation and (B) crystal structure of the nucleosome solved at $1.9 \AA$ (PDB code $1 \mathrm{kx} 5,[6]) .147 \mathrm{bp}$ of DNA (grey) are wrapped around an octamer consisting of two copies of each core histone, H3, H4, H2A and H2B. The unstructured N-terminal histone tails protrude from the nucleosomal core. Image generated with Pymol based on structural data of PDB entry $1 \mathrm{kx} 5$. View down the superhelical DNA axis is shown. 


\subsubsection{Folding of chromatin into higher-order structures}

Different levels of spatial organization accomplish the enormous compaction of eukaryotic genomes. In the first order nucleosomes are arranged on DNA with intervening linker space to form a 'beads on a string' like structure [4]. The linker DNA length thereby varies between 10-80 base pairs in a species- and tissue-specific manner [7, 8]. A fifth histone, the linker histones H1, connects two neighboring nucleosomes and thereby organizes about 20 base pairs of that linker DNA.

Physiological salt conditions and the presence of the linker histone H1 promote the formation of a helical fiber with a $30 \mathrm{~nm}$ diameter - the next level of higher-order chromatin structure. However, the structure of the $30 \mathrm{~nm}$ fiber and the role of $\mathrm{H} 1 \mathrm{in}$ filament organization remain controversial $[9,10]$. The structural organization beyond the $30 \mathrm{~nm}$ fiber up to metaphase chromosomes is poorly understood. It presumably involves long-distance interactions and looping of chromatin fibers (Figure 1.2).

Albeit the significant degree of compaction, chromatin represents a highly dynamic structure. In fact, mobilization of histones/nucleosomes proves essential for all DNArelated processes like replication, transcription, recombination and repair. Even though the described repetitive nature of chromatin structure implies a high degree of homogeneity, chromatin exists in different configurations.

\subsubsection{Heterogeneity of chromatin within the nucleus}

Historically, chromatin was described to exist in two cytological different configurations: euchromatin and heterochromatin [11]. This distinction was based on the heterogeneous staining intensities observed with nuclear dyes.

The intensely stained heterochromatin is reckoned to be a more densely compacted form of chromatin, limiting the access of the gene expression machinery and therefore often corresponds to transcriptionally silenced domains. Further features of heterochromatin include low gene density, a high content of repetitive sequences and late replication in S-phase [12]. Besides constitutive heterochromatic structures like centromeres and telomeres that ensure accurate chromosome transmission through mitosis and meiosis, the term facultative heterochromatin refers to regions that get silenced during development and cell differentiation events. One paradigm is the inactivation of one X-chromosome in female mammalian cells [13]. Unlike 
heterochromatin, euchromatin is only lightly stained by chromatin-specific dyes, appears to be more decondensed, replicates early in S-phase and is believed to contain the majority of transcriptionally active genes [12, 14].

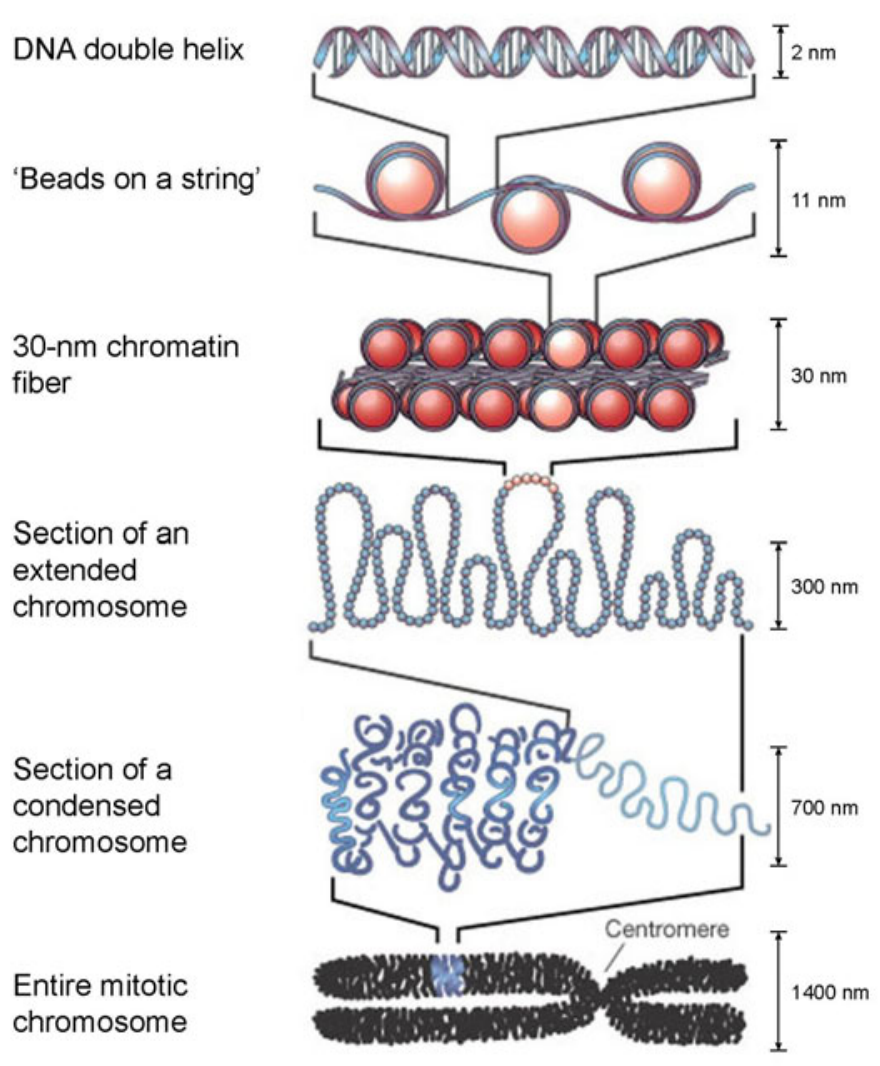

Figure 1.2 | Hierarchical levels of chromatin condensation. Several hierarchical levels of packaging accomplish the spatial organization of chromatin inside the cell nucleus. First nucleosomes are arranged like 'beads on a string' on DNA. These arrays fold into a $30 \mathrm{~nm}$ fiber by internucleosomal interactions. Relatively little is known about folding beyond the $30 \mathrm{~nm}$ level (adapted from [7]).

This oversimplified view of connecting euchromatin with gene-rich, transcriptional active regions of the genome whereas heterochromatin represents gene-poor and transcriptional silent domains has been challenged by numerous studies [15]. Presumably, chromatin exists in many more subcategories characterized by different structural, biochemical and functional properties. Still, this simple classification demonstrates that chromatin represents more than a simple scaffold for DNA. It rather regulates genomic processes, which in turn requires mechanisms that control and manipulate chromatin structure. 


\subsection{Modulation of chromatin structure}

\subsubsection{Histone variants}

Whereas the repetitive packaging of DNA into nucleosomes is fundamentally the same throughout the genome, variation is achieved by incorporation of histone variants and a number of posttranslational modifications on core and linker histones. Histone variants can be found in all histone classes with the exception of histone H4. Thereby, the H2A histones represent the most diverse class (Table 1.1). Histone variants are distinct with respect to their sequence, function and/or localization. For example, H3.3, a replication-independent variant of the canonical H3 histone, correlates with transcriptional active regions [16], whereas CENP-A replaces H3 at centromeric regions and functions in kinetochore assembly [17].

Some histone variants show only minor sequence variation compared to their canonical counterparts. The above mentioned H3.3 varies only by 4-5 amino acids from canonical H3. Most histone variants, however, are quite divergent in sequence and structure from the canonical form. This includes all H2A variants and also the H3 variant CENP-A.

Another difference between the major histones and histone variants is their expression and deposition profile. Canonical histone genes are intron-less and occur in gene clusters. Their expression is tightly coupled to S-phase whereas histone variants are expressed from intron-containing genes throughout the cell cycle [18, 19]. The majority of histone deposition takes place during S-phase and mainly involves the canonical histones. These are produced in large quantities just prior to DNA replication and thus presumably compete for incorporation with histone variants.

The altered structure, constitutive expression and deposition outside of S-phase suggests that the incorporation of variants can potentially change chromatin regions in respect to their structure, transcriptional activity and biochemical composition. Table 1.1 gives an overview of the localization and functions of canonical histones and their major histone variants in mammals. 
Table 1.1 | Localization and function of canonical core histones and histone variants in mammals (canonical histones in bold).

\begin{tabular}{|c|c|c|c|}
\hline Histone & Localization & Function & Reference \\
\hline "H3.1 & genome-wide & $\begin{array}{l}\text { canonical histone ( } \mathrm{RC} \\
\text { assembly) }\end{array}$ & [20] \\
\hline H3.2 & genome-wide & $\begin{array}{l}\text { canonical histone ( } \mathrm{RC} \\
\text { assembly) }\end{array}$ & \\
\hline \multirow[t]{2}{*}{ H3.3 } & $\begin{array}{l}\text { a) euchromatin, promoter, } \\
\text { gene bodies }\end{array}$ & $\begin{array}{l}\text { transcriptional activation (RI } \\
\text { assembly) }\end{array}$ & {$[16,21]$} \\
\hline & $\begin{array}{l}\text { b) telomeres, pericentric } \\
\text { repeats }\end{array}$ & N.D. & {$[22]$} \\
\hline $\mathrm{H} 3 \mathrm{~T}$ & testis & N.D. & {$[23]$} \\
\hline CENP-A & centromere & kinetochore assembly & {$[17]$} \\
\hline H4 & genome-wide & $\begin{array}{l}\text { canonical histone (RC/RI } \\
\text { assembly) }\end{array}$ & \\
\hline H2A & genome-wide & canonical histone & \\
\hline H2A.X & $\begin{array}{l}\text { XY Body, sites of } \\
\text { double-strand DNA } \\
\text { breaks }\end{array}$ & marker of DNA lesions & {$[24]$} \\
\hline H2A.Z & $\begin{array}{l}\text { regulatory elements, } \\
\text { promoter, pericentric } \\
\text { repeats }\end{array}$ & $\begin{array}{l}\text { transcriptional activation, } \\
\text { nucleosome instability }\end{array}$ & {$[21,25]$} \\
\hline MacroH2A & $\begin{array}{l}\mathrm{X}_{\mathrm{i}} \text { chromosome, } \\
\text { promoters }\end{array}$ & $\mathrm{X}$ inactivation & {$[26,27]$} \\
\hline H2A.L & $\begin{array}{l}\text { pericentric repeats of } \\
\text { spermatids }\end{array}$ & N.D. & {$[28]$} \\
\hline H2A.Bbd & excluded from $X_{i}$ & $\begin{array}{l}\text { destabilizing protein-DNA } \\
\text { interaction }\end{array}$ & {$[29]$} \\
\hline $\mathrm{TH} 2 \mathrm{~A}$ & testis & N.D. & {$[30]$} \\
\hline H2B & genome-wide & canonical histone & \\
\hline $\mathrm{TH} 2 \mathrm{~B}$ & testis & N.D. & {$[31]$} \\
\hline
\end{tabular}

\subsubsection{Posttranslational modifications}

Despite histone variants that are incorporated into the genome and determine functional distinct chromatin areas, posttranslational modifications on histones can further enhance the variability and potential differentiation of chromatin regions. Up to now, a large catalogue of covalent histones modifications (or histone marks) has been compiled and is extending ever more. The predominant targets of modifications are the histone tails albeit an increasing numbers of altered residues are identified within the histone fold [32]. 
Methylation and acetylation of lysines comprise the most abundant types of modification. Furthermore, methylation of arginine residues and phosphorylation of serine or threonine residues can be detected (Figure 1.3). Besides these rather small modifications more bulky structures can be introduced by ubiquitinylation and sumoylation of lysines and ADP-ribosylation of glutamates [32].

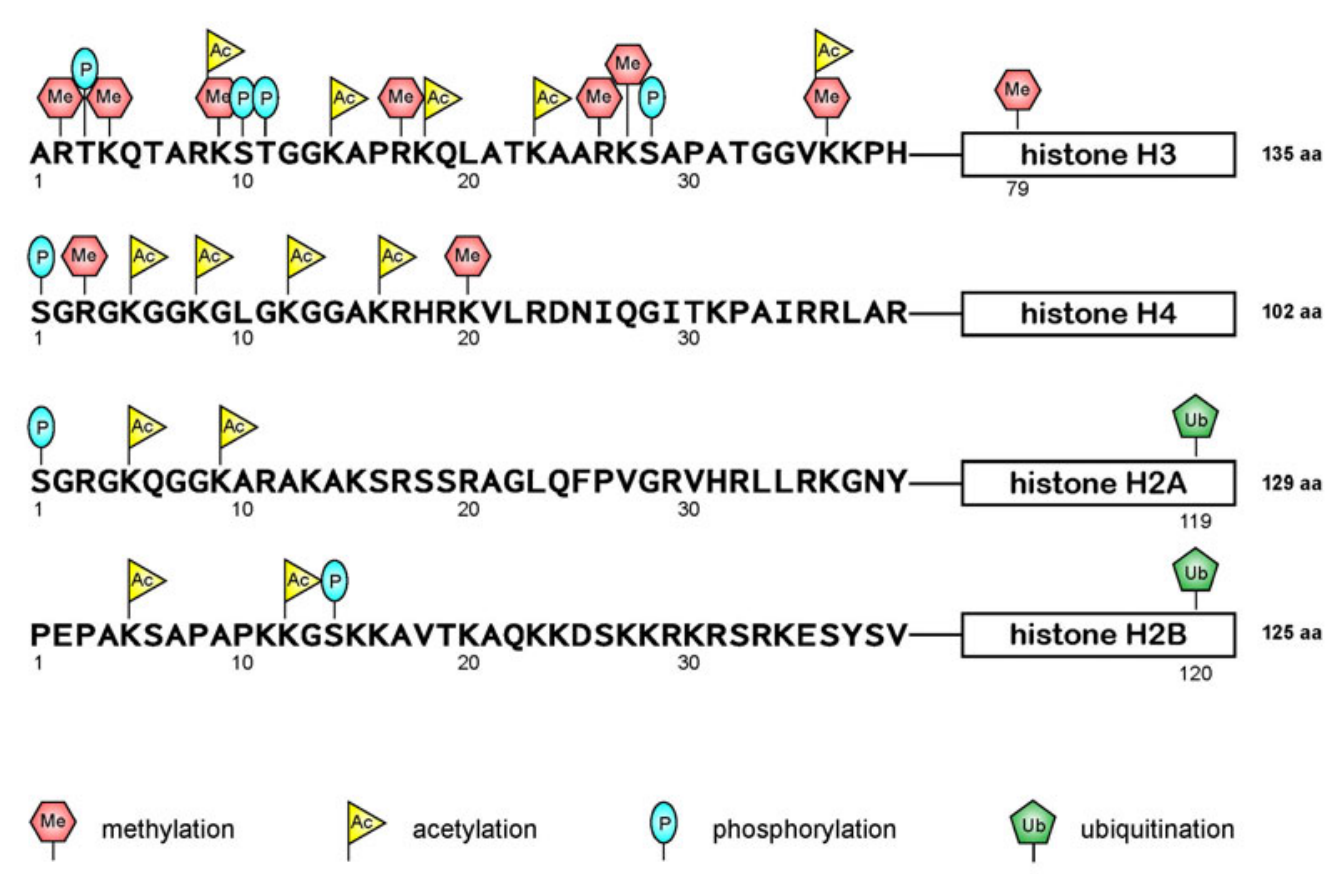

Figure 1.3 | Major sites of histone modifications on human core histones. Most histone modifications are present on the amino terminal tails. Here, amino acids (aa) 1-39 of each histone are depicted. Residues within the histone-fold domain (boxed) are also modified. Prevalent modifications include methylation (red Me hexagon) of lysine and arginine, acetylation (yellow Ac flag) of lysine, phosphorylation (blue P ellipse) of threonine or serine and ubiquitination (green Ub trapezoid) of lysine residues (image based on [2]).

The complexity is further extended by the different degrees of methylation that can occur on lysines (mono-, di-, trimethylation) and arginines (monomethylation and symmetrically and asymmetrically dimethylation).

Methylation is mediated by enzymes called histone methyltransferases (HMTs). Theses enzymes often exhibit a high degree of specificity for a certain histone and a particular residue. Proteins of the $\mathrm{Su}(\mathrm{var}) 3-9$ class for instance only methylate lysine 9 on histone H3 (written H3K9me1, 2 or 3) [33]. Notably, recent studies suggest that histone methyltransferases also target non-histone proteins [34]. Methylation itself is a stepwise process and not all HMTs are capable of introducing mono-, di- and 
trimethylation [35]. One example is PR-Set7, which only transfers H4K20me1 but not H4K20me2/3 [36, 37].

\subsubsection{PR-Set7 - a monomethyltransferase}

Whereas H4K20 monomethylation was discovered more than 40 years ago [38], the responsible methyltransferase PR-Set7 was only identified recently by biochemical fractionation of HeLa cell nuclear extract $[36,39]$. Like most methyltransferases the catalytic subunit of PR-Set7 is comprised of a SET-domain that utilizes S-AdenosylL-methionine (SAM) as a cofactor. Further biochemical and structural analyses revealed that PR-Set7 strictly mediates monomethylation of H4K20 [37, 40, 41]. The higher methylation states H4K20me2 and me3 are mediated by enzymes named Suv420 [42]. In contrast, a single enzyme (Set9) appears to be solely responsible for all three states of H4K20 methylation in S. pombe [43]. The question why these different methyltransferases for H4K20 have evolved is unsolved. Interestingly, depletion of the monomethyltransferase PR-Set7 leads to reduction of di- and trimethylation levels of H4K20 [44]. Consistent with these observations H4K20me1 is the preferred substrate for Suv4-20 proteins and not unmethylated H4K20 [45, 46]. Thus, the biology of these enzymes seems to be interconnected.

\subsubsection{Stability of histone modifications}

The highly dynamic acetylation levels of the genome are regulated by opposing activities of histone acetyltransferases (HAT) and histone deacetylases (HDAC) [47, 48]. Many transcriptional coactivators like p300 or Gen5 contain HAT domains to acetylate histone proteins whereas the numerous HDACs are often embedded in corepressor complexes [49].

For a long time it was believed that methylation represents a far more stable modification than acetylation. Especially, lysine trimethylation was thought to be irreversible and therefore considered a truly epigenetic mark. The discovery of the first demethylase LSD1 in 2004 and of the Jumonji domain proteins over the past years proved this assumption to be wrong $[50,51]$. 


\subsubsection{Functional consequences of histone marks}

Modifications have been found on every histone class, their global distribution, however, is not uniform. The local enrichment of certain types of modifications is known to correlate with functional distinct regions in the genome. In this sense, a formal distinction can be made between activating and repressing marks.

Early on it was noticed that posttranslational modifications, in particular histone acetylation, stand in close relation to RNA polymerase activity [52]. Whereas histone hyperacetylation usually corresponds to transcriptional activation, histone hypoacetylation is associated with reduced gene activity. Methyl marks can function in both directions depending on the histone type, the particular residue as well as the degree of methylation (Table 1.2).

Table 1.2 | Common histone modifications and their biological function (based on [2, 32]

\begin{tabular}{ll}
\hline Histone modification & Biological function \\
\hline H3K4me1 & transcription activation \\
H3K4me2 & transcription activation \\
H3K4me3 & transcription activation \\
\hline H3K9me1 & active transcription? / pre-deposition mark? \\
H3K9me2 & transcriptional repression \\
H3K9me3 & transcriptional repression \\
\hline H3K27me1 & activation \\
H3K27me2 & transcriptional repression \\
H3K27me3 & transcriptional repression \\
\hline H4K20me1 & cell cycle progression / activation / silent chromatin \\
H4K20me2 & silent chromatin / DNA damage response? \\
H4K20me3 & heterochromatin (facultative?) / silent chromatin \\
\hline H4K5ac & pre-deposition mark / activation \\
H4K12ac & pre-deposition mark / activation \\
H4K16ac & activation \\
\hline H3K9ac & activation \\
H3K14ac & activation \\
\hline H3/H4 - histone H3/H4 & lysine residue (followed by residue number) \\
me1/2/3 - mono-/di-/trimethylation \\
ac - acetylation,
\end{tabular}




\subsubsection{H4K20 methylation - a multi-faceted histone modification}

The different states of H4K20 methylation depict how varied the functional read-out of a single residue can be. As described, H4K20me1 is mediated by PR-Set7 whereas Suv4-20 enzymes introduce H4K20me2/3. Mechanistically little is known about the role of these modifications. The higher methylation states correlate with silenced chromatin and are implicated in DNA damage response [42, 43]. The observations made on H4K20me1 function are more contradictory. It was shown to be involved in mitotic processes, in transcriptional silencing as well as gene activation [53]. To assess the true function of these modifications it is thus important to understand the mechanisms underlying the read-out of histone modifications.

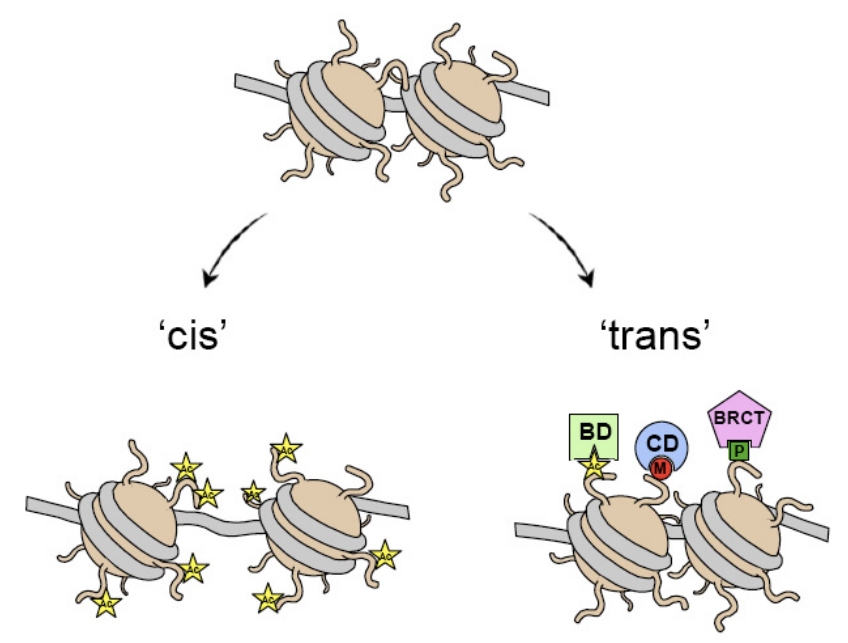

Figure 1.4 | Molecular read-out of histone modifications. In principle, covalent histone modifications act by two mechanisms. They either change intra-/internucleosomal contacts resulting in an altered structure or charge ('cis'-effects). Or they act in 'trans' by recruiting proteins that contain binding domain such as bromodomains (BD, acetyl-lysine binders), chromodomains (CD, methyllysine binders) or BRCT domains (phospho-serine/threonine binders). These effector proteins can further transmit functional consequences (adapted from [54]).

\subsubsection{Molecular read-out of histone modifications}

In general the correlation between histone marks and a functional consequence can be achieved in two ways. (i) Histone modification can alter chromatin structure and genome accessibility by direct ('in cis') interaction with adjacent nucleosomes. One example is transcriptional activation and decompaction of chromatin by acetylation of lysine 16 on histone $\mathrm{H} 4$ (H4K16ac) [55]. (ii) Histone marks affect gene regulation in trans' via recruitment of proteins specifically recognizing particular marks [56]. Such 'readers' might in turn recruit additional factors ('effectors') for further signal transduction (Figure 1.4). 
Most readers were shown to contain common motifs that bind a certain type of modification. Bromodomains bind to acetylated lysine residues whereas methylation is recognized by protein motifs like chromodomains, MBT repeats, Tudor domains, WD40 repeats and PHD fingers [57].

\subsubsection{The impact of remodeling machineries on chromatin structure}

One question arising is how cells manage to incorporate modifications and variants into the dense structure of chromatin? Furthermore, processes like transcription require access to DNA. By default, however, the access to DNA is virtually blocked by nucleosomes. In order to render DNA accessibility, multiprotein machineries exist that utilize ATP-hydrolysis to mobilize nucleosomes [58]. The common feature of these remodeling complexes is the dedicated ATPase subunit on which basis they are grouped into three families [59, 60]: The SWI/SNF, the ISWI and the Mi2-NuRD class.

Generally, three modes of remodeling have been reported: (i) nucleosome sliding along a DNA template, (ii) nucleosome eviction and (iii) replacement of histone proteins within existing nucleosomes [61]. All three mechanisms have the potential to change DNA-histone interfaces and alter (higher-order) chromatin structure. The exact mechanism of how ATP-hydrolysis is coupled to structural changes is not completely understood. Another question is the recruitment of remodeling complexes to chromatin. Interaction with RNA Polymerase II, transcription factors as well as binding to DNA has been reported. Some remodelers also bind to nucleosomes by recognizing histone modifications through binding modules like bromodomains and $\mathrm{PhD}$ fingers [62]. Especially acetylation and deacetylation play a major role in recruiting remodeling complexes for gene transcription or repression.

Chromatin remodeling complexes have been implicated to be involved in many processes besides transcription. Since these complexes take part in chromatin assembly and partially exhibit enzymatic activity like acetylation or deacetylation, they presumably directly contribute to chromatin modulation and thus epigenetic phenomena. 


\subsection{Chromatin assembly}

The deposition of histones on DNA is the fundamental basis for epigenetic inheritance. It ensures that certain chromatin states are maintained inside a single cell and/or transmitted throughout cell divisions to daughter cells. This requires not only proteins that deposit histones on DNA but also proteins or complexes that maintain the chromatin modification status or the presence of certain histone variants. Many of the discussed remodeling complexes contain subunits that show an affinity for histone proteins. These histone-binding modules are referred to as chaperones.

\subsubsection{Histone chaperones}

These recurrent and manifold binding partners participate in every assembly, disassembly, exchange or transfer process involving histone proteins.

Histone chaperones do not exhibit a common structural motif for histone binding. Their structural diversity is mirrored by the existence of monomeric, dimeric or oligomeric chaperone structures and their ability to function autonomously and as parts of larger complexes. From that perspective chaperones can be divided into three classes [63]: (i) single chaperones that bind and transport histones autonomously like Asf1; (ii) multichaperone complexes containing more than one histone chaperone subunit (e.g. p60, p150 and RbAp48 - the subunits of CAF-1); and (iii) chaperones embedded in large enzymatic complexes that target histones like the chaperone RbAp48 within the Mi2/NuRD deacetylase complex. The latter one, RbAp48 (also known as Rbbp4) has to be classified as a multifunctional chaperone as it fits into all three classes.

Another way to classify histone chaperones is based on their affinity towards a specific histone type. Most histone chaperones either bind H2A-H2B or H3-H4 complexes. This fact is in agreement with the notion that de novo assembly of nucleosomes is a stepwise process with $\mathrm{H} 3-\mathrm{H} 4$ being deposited first onto DNA, followed by incorporation of two H2A-H2B dimers [64-66]. A short summary of histone chaperones and their known histone and non-histone binding partners is listed in Table 1.3. 
Table 1.3 | Histone chaperones and binding partners (adapted from [67], see references therein).

\begin{tabular}{lll}
\hline Chaperone classification & Histone chaperone & Binding partners \\
\hline \hline H3-H4 family & Asf1 & H3-H4 dimer, HIRA, CAF-1, RCF, MCMs, Bdf1 \\
& CAF-1 & H3-H4, Asf1, HP1, PCNA, MBD1, Rtt106 \\
& HIRA & H3-H4 (H3.3), Asf1, Pax3, SWI/SNF \\
& DAXX & H3-H4 (H3.3), part of ATRX \\
& RbAp48 & H3-H4, part of HAT1, CAF-1, HDAC1-3, PRC2, \\
& Nucleolin & HURF and NuRD complexes \\
\hline H2A-H2B \\
& PP2C $\gamma$ & H2A-H2B \\
\hline H2A-H2B/H3-H4 family & FACT & H2A-H2B, H3-H4, H2A.X, MCMs, HP1, RPA \\
& N1/N2 & H3-H4 \\
& nucleoplasmin & H2A-H2B \\
& DEK oncogene & H2A-H2B, H3-H4, PCK \\
& Chz1 & H2A.Z-H2B \\
\hline Variant histones & Yaf9 & H2A.Z-H2B, NuA4 subunit, SWR1 subunit \\
& HJURP & CENP-A \\
\hline Core/linker histones & NAP1 & H3-H4, H2A-H2B, H1 \\
& NASP & H3-H4, H2A-H2B, H1 \\
\hline
\end{tabular}

As depicted in Table 1.3 very few histone chaperones have been identified that exclusively bind one of the numerous histone variants. Namely, this is only true for H2A.Z, CENP-A and presumably H3.3 [20, 68-70]. An explanation for this discrepancy could be the different expression profile of variants and canonical histone mentioned before. During S-phase canonical histones by far outnumber histone variants whereas outside of S-phase hardly any expression of canonical histones occurs and is apart from that highly toxic for the cell [71-73]. A study in Drosophila cells by Henikoff and colleagues [16] examined the distribution of GFP fusions of H3.3 and the canonical, replication-dependent H3. Their results showed that H3-GFP deposition is essentially coupled to DNA synthesis since no incorporation was found in presence of aphidicolin, an inhibitor of DNA polymerase activity. Incorporation of H3.3-GFP as well as H4-GFP, however, was not affected in cells where DNA synthesis was blocked. This clearly demonstrated a second deposition pathway independent of DNA synthesis.

The major H3-H4 chaperone so far connected with assembly during S-phase is CAF-1 (chromatin assembly factor 1). In contrast, chromatin assembly outside of S-phase is mediated by HIRA (histone regulator A). A prominent difference between both 
chaperones is their binding specificity towards H3. Whereas CAF-1 associates with conventional H3-H4 complexes, HIRA is thought to bind the replication-independent H3.3 histone [20]. Interestingly, their binding specificities and shifted activity during cell cycle mirror the expression profiles of canonical histones and histone variants. It remains unknown whether this also reflects different functionality of the chromatin assembled by each chaperone. The investigation of these different chromatin assembly pathways and the involved proteins has been a subject of intense research over the last two decades.

\subsubsection{Experimental approaches towards reconstitution of functional chromatin states}

Monitoring chromatin assembly in vivo is not only hindered by accessibility to nuclear structures but also by time-resolution of the process. Therefore, a variety of experimental in vitro set-ups have been established over the last decades to dissect the molecular mechanisms of chromatin assembly.

\subsubsection{Recombinant chromatin}

Chromatin reconstitution systems using specific DNA sequences and recombinant histone proteins provided insights into the nucleosomal core structure on the atomic level [5]. The reconstitution is based on the finding that nucleosomal structures dissociate under high salt conditions $(>1.2 \mathrm{M} \mathrm{NaCl})$ and that this process is reversible [74]. Basis for the success of this system was also the identification of natural and artificial DNA sequences that exhibit a high affinity towards histones and therefore not only prevent loss of octamers from linear DNA molecules but also mediate correct spacing/positioning of nucleosomes on DNA [75, 76]. Later on, recombinant remodeling complexes like Drosophila NAP-1 and ACF that correctly space nucleosomes on DNA were also employed to assemble recombinant histones on DNA sequences $[77,78]$.

Despite crystallography analysis of the nucleosomal core particle these recombinant systems have proven useful for studying the impact of salt, histone modifications, histone variants or non-histone proteins on chromatin structure. Incorporation of H4K16ac into recombinant chromatin templates was shown to prevent formation of 
the $30 \mathrm{~nm}$ fiber and thus higher chromatin compaction [55]. Further, the transition from a 'beads on a string' structure to the $30 \mathrm{~nm}$ fiber by salt and histone $\mathrm{H} 1$ has been mainly analyzed with recombinant oligomeric chromatin arrays. Two main models, the 'solenoid' and 'two-start helix' model, have evolved from these analyses [9, 10]. However, compaction of chromatin in vivo depends on more than salt conditions and H1. In fact, a not foreseeable amount of non-histone proteins, histone variants and modifications is likely to be involved. Such a complexity cannot be met by an artificial reconstitution system.

\subsubsection{SV40 replication system}

Valuable insights into chromatin assembly coupled to DNA replication were gained using the Simian Virus 40 (SV40) replication system [79]. SV40 is a small DNA tumor virus found in monkeys and humans. Initiation of replication is absolutely dependent on the viral large $\mathrm{T}$ antigen, a multifunctional molecular chaperone with ATPase activity, and a DNA plasmid containing the SV40 origin of DNA replication [80]. DNA replication proceeds bidirectional on plasmids in presence of a crude cytosolic cell extract and is thought to closely resemble eukaryotic DNA replication. The chromatin assembly factor 1 (CAF-1) was first isolated and characterized in this system as an essential factor promoting chromatin assembly coupled to replication [81]. CAF-1 was later shown to be a H3-H4 histone chaperone preferentially binding to acetylated histones $[82,83]$. Further experiments demonstrated that the p150 subunit of CAF-1 directly binds to proliferating cell nuclear antigen (PCNA) in vitro. Presumably, the interaction of PCNA and CAF-1 is responsible for tethering of CAF1 to sites of replication in vivo $[84,85]$. The SV40 system only mediates chromatin assembly by CAF-1 during DNA replication and is dependent on various components originating from different sources (e.g. cellular extracts, viral components).

\subsubsection{Cell-free assembly systems using extracts from Drosophila and Xenopus}

Octamers or histones will not spontaneously form nucleosomes with free DNA at physiological salt conditions but instead require a variety of assembly factors. Extracts derived from Drosophila embryos or Xenopus laevis eggs and oocytes were found to be an excellent source of assembly factors. Indeed, early studies demonstrated that fractionated extracts from $X$. laevis eggs support assembly of the 
SV40 viral genome into a minichromosome-like structure [86] The ability of crude extracts to replicate DNA and assemble nuclear structures was shown in subsequent studies [87-89] and led to the development of cycling extracts, which recapitulate multiple rounds of cell cycle in vitro [90]. Chromatin assembled in Xenopus egg extracts is evenly spaced and assembly requires ATP-hydrolysis and topoisomerase activity [91, 92].

Chromatin assembly assays in Drosophila embryonic extracts showed that chromatin itself is a major repressor of transcription [93] and that this repression can be overcome by remodeling of chromatin and binding of transcriptional activators [94]. Notably, both systems are capable of second-strand synthesis on single-stranded DNA, a process thought to resemble lagging strand synthesis. Lagging strand synthesis is tightly coupled to chromatin assembly. Whereas Drosophila extracts require short double-stranded regions to perform this task, Xenopus egg extracts do so autonomously on single-stranded DNA [87, 95].

Of the described experimental assembly strategies these cellular extracts are thought to resemble the in vivo situation the closest and totally rely on factors present in the extract. In particular in X. laevis eggs the maternal stockpile of proteins, RNAs, and nucleotides is enormous [96]. Moreover, the extract systems are open to manipulation like depletion and supplementation. The impact of single proteins on chromatin assembly can thus be studied in this system [87, 97, 98].

Altogether, studies on chromatin assembly indicated that different modes of assembly exist that potentially employ a variety of nuclear factors.

\subsubsection{Assembly pathways}

Work over the last years has shown that chromatin assembly can be divided into two main pathways. A pathway coupled to DNA synthesis, which includes DNA replication and DNA repair and a pathway independent of DNA synthesis. In this thesis I will refer to the first pathway as replication-coupled $(R C)$ assembly and to the second one as replication-independent (RI) assembly. Even though this distinction has been made in the literature, there is considerable doubt whether both pathways operate exclusively or are interconnected by e.g. utilizing the same chaperones, remodeling complexes or other proteins. 
Without question, both pathways share a common influx originating from the synthesis of histones in the cytoplasm and their transport into the nucleus. The newly synthesized histones are acetylated in the cytoplasm by HAT1 [47, 99, 100]. Then histones are presumably bound by the chaperone Asf1 and importin 4 [101] and shuttled into the nucleus where Asfl feeds histones into either one of the pathways by interaction with chaperones like HIRA and CAF-1 [98, 102, 103]. Prominent marks of newly synthesized histones in humans include H4K5ac and H4K12ac [104]. These marks are still present on nucleosomes after deposition onto DNA but quickly get erased afterwards [105]. Further, H3K9me1 has been reported as a mark associated with newly synthesized histones [106].

\subsubsection{Replication-coupled assembly}

During DNA replication DNA unwinding is accompanied by transient disruption of parental nuclesomes ahead of the replication fork. As soon as a new daughter strand is synthesized nuclesomes are deposited onto nascent DNA. The key player in this kind of assembly has already been introduced as the histone chaperone CAF-1. It comprises the three subunits p150, p60 and p48 (RbAp48/Rbbp4) and is recruited to sites of replication via interaction with PCNA [81, 85]. Much debate is going on about the fate of old and new histones that are used during the de novo deposition of nucleosomes and how existing histone modifications could potentially be transmitted to the next cell generation [107].

In agreement with its function during DNA replication knock-down of CAF-1 showed that it is essential in proliferating but not in quiescent cells [108]. Mutagenesis of the p150 subunit of CAF-1 revealed that it is an important factor for maturation of heterochromatin in preimplantation mouse embryos causing lethality at the 16-cell stage and abnormal heterochromatin structures [109]. Follow-up studies demonstrated that this might be due to its interaction with heterochromatin protein 1 (HP1), a major component of constitutive heterochromatin [110].

It further appears like CAF-1 is only able to bind to canonical H3.1 and/or H3.2 but not the replication-independent $\mathrm{H} 3.3$ variant [20]. The role of $\mathrm{H} 2 \mathrm{~A}-\mathrm{H} 2 \mathrm{~B}$ chaperones in RC assembly has not been explored in detail. Several studies imply that H2A-H2B eviction and deposition is facilitated by FACT during replication as well as independent of DNA synthesis during transcription [111]. FACT was recently shown 
to interact with MCM proteins, the major constituents of the DNA helicase involved in DNA replication $[112,113]$.

Despite the changing acetylation pattern during chromatin assembly and incorporation of canonical H3 virtually nothing is known about the properties of newly established chromatin by the RC pathway. Moreover, the functional consequences of this pathway remain obscure. It is unknown how perceptible chromatin is after RC assembly for e.g. transcription or remodeling and whether histone variants are incorporated at all during RC assembly.

\subsubsection{Replication-independent assembly}

As mentioned before a minor fraction of histone deposition, especially of histone variants, is not dependent on DNA synthesis [16]. This second pathway of chromatin assembly was linked to HIRA and has only become a subject of investigation over the last years $[20,97]$. Human HIRA is a $110 \mathrm{kDa}$ protein distantly related to CAF-1 and also exhibits a preference for H3-H4 complexes. Chromatin assembly on naked DNA in Xenopus egg extracts is mainly mediated by HIRA [97]. How HIRA recognizes free DNA or whether other proteins actively recruit HIRA to DNA is currently unknown.

An elegant study showed that immunoprecipitation of ectopically tagged H3.3 from mammalian cells coprecipitates HIRA. Precipitation of $\mathrm{H} 3.1$ instead led to copurification of CAF-1 [20]. Although H3.3 was first conceived to be a true marker of euchromatic, trancriptionally active regions $[16,114,115]$ the very recent discovery of two more H3.3-H4 binding chaperones challenged that view. In 2010 several studies reported deposition of H3.3-H4 by DAXX (Death associated protein 6) that was identified as part of the ATRX remodeling complex [22, 116-118]. In contrast to HIRA, DAXX incorporates $\mathrm{H} 3.3$ at telomeres and pericentric heterochromatin, both transcriptionally silent regions. Moreover, the DEK oncogene, a ubiquitous nuclear protein involved in tumorgenesis, was established as a third H3.3 specific histone chaperone. It deposits H3.3 replication-independent through interaction with nuclear receptors to regions of high transcriptional activity [119]. Accordingly, the true function of H3.3 incorporation remains unclear. However, posttranslational modifications associated with $\mathrm{H} 3.3$ are mainly active histone marks like H3K4me1/2/3, H3K14ac and H3K9ac [106, 115]. 


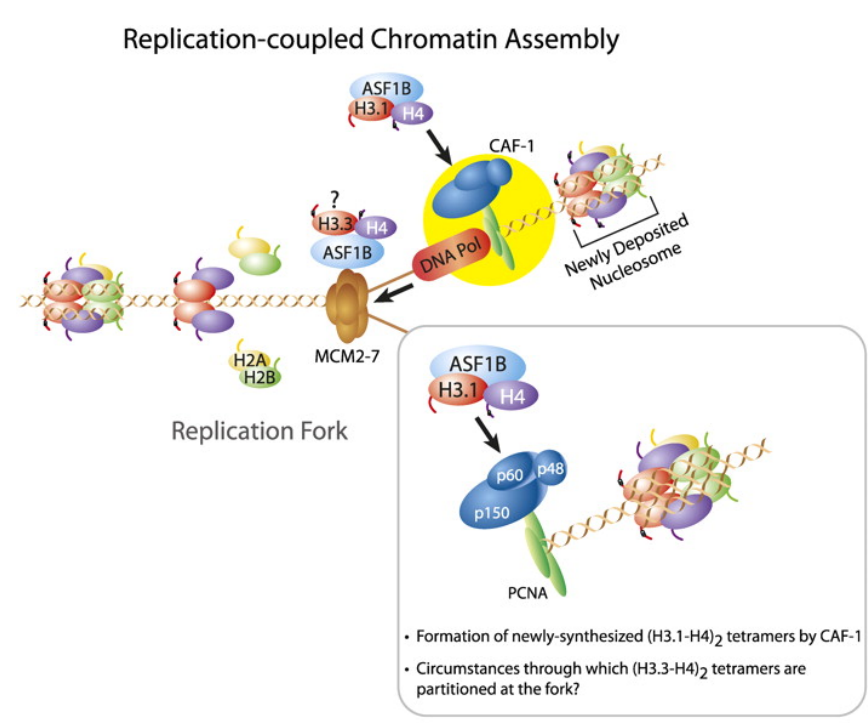

DAXX-ATRX Chromatin Assembly

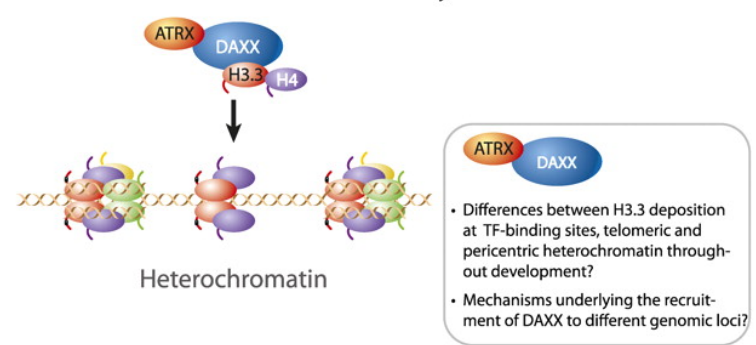

Replication-independent Chromatin Assembly

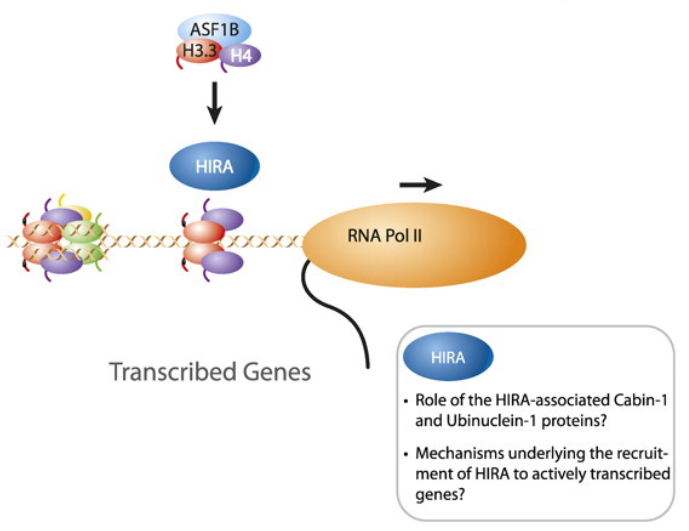

DEK-mediated H3.3 Histone Replacement

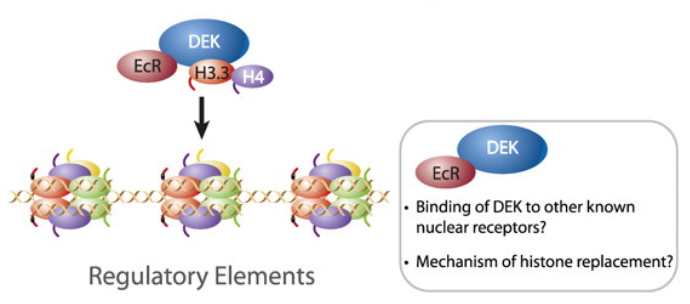

Figure 1.5 | Chromatin assembly pathways and histone replacement. Two general pathways for chromatin assembly have been described. During DNA replication chromatin is assembled by the action of CAF-1 that deposits H3-H4 onto nascent DNA. Outside of S-phase HIRA can mediate H3-H4 deposition and thus chromatin assembly of e.g. transcribed genes. Both pathways are supplied with H3$\mathrm{H} 4$ histones through the Asfl chaperone. Alternative pathways for H3.3 incorporation include assembly by DAXX-ATRX complex at telomeres and pericentric heterochromatin as well as histone exchange via the DEK oncogene upon recruitment by nuclear receptors like the ecdysone receptor (EcR) (image taken from [120]).

Replication-independent assembly does not only plays a role for transcriptionally active chromatin domains. It is also necessary for sperm chromatin decondensation during fertilization. In Xenopus laevis sperm decondensation involves the chaperones $\mathrm{N} 1 / \mathrm{N} 2$ and nucleoplasmin that actively replace sperm specific proteins with maternal histones [121, 122]. Interestingly, H3.3 incorporation by HIRA seems to play a major role in paternal pronucleus formation during fertilization in Drosophila melanogaster and mice [123-125]

\subsubsection{Why does the cell need more than one chromatin assembly pathway?}

Knock-out of CAF-1 as well as HIRA cause embryonic lethality [109, 126]. This suggests that both pathways are non-redundant processes. Notably, in S. cerevisiae 
CAF-1 is not essential for histone deposition. Here, the chaperones HIRA and Asf1 can substitute for chromatin assembly mediated by CAF-1 [127] implicating that RI and $\mathrm{RC}$ assembly are redundant processes in budding yeast. However, unlike higher organism S. cerevisiae contains only one type of H3 histones that more closely resembles H3.3 than H3.1 [128]. This fact might circumvent the need for two independent chromatin assembly pathways.

The majority of the small yeast genome is in a transcriptionally poised state and very few, specialized sites require a repressed state [2]. In organisms higher than budding yeast evolution of genomes is coupled to an increase in size and a decreasing ratio of coding to non-coding DNA sequences. Moreover, evolution is linked to cellular differentiation, which is inevitably coupled to the need for activation and repression of tissue-specific genes. The main function of replication-coupled assembly is the efficient chromatin assembly of the duplicated chromatids, which in turn is important for chromosome segregation during cell division. Here, a chromatin assembly pathway independent from DNA replication could implement the necessary modulation of chromatin structure and thus cause expression and repression of certain genes without affecting DNA replication. If this were true then RC assembled chromatin could resemble a default state that is modulated by RI assembly. Nevertheless, certain modifications and variants persist through cell divisions and presumably replication.

It is unknown whether one of these distinct assembly pathways directly induces for example repressive or active histone modifications. To thoroughly understand the influence of either pathway on chromatin functions like gene expression more research is necessary dissecting not only the mechanisms of assembly but also their consequences for chromatin structure and composition. 


\subsection{Objectives of the presented thesis}

It is evident that modulation of chromatin structure by mechanisms like histone variants, histone modifications, specific assembly factors and remodeling machineries results in differential gene expression. Chromatin structure can be assembled by at least two pathways. One pathway coupled to DNA synthesis (RC assembly) and another independent of DNA synthesis (RI assembly). Whether both assembly pathways directly contribute to certain chromatin signatures and functions is largely unknown. Most studies have focused on either one of the assembly pathways but not compared both side-by-side on a biochemical and functional level.

My hypothesis was that the two assembly pathways lead to different chromatin species presumably reflected by variations in higher order structure, histone modifications, histone variants, associated non-histone proteins and by a different functional competence.

To address these questions, I decided to set-up a cell-free chromatin assembly system in Xenopus laevis egg extracts. With this system and appropriate DNA templates, I wanted to analyze chromatin species derived by each pathway in respect to histone modifications, histone variants as well as associated non-histone proteins. Therefore, immunodetection methods as well as mass spectrometry analyses were employed. The impact of proteins found by these assays could then be tested in the biochemically open assembly system. Besides the biochemical analyses I envisioned that structural analyses by e.g. atomic force microscopy could be used on purified chromatin structures to reveal potential differences in higher order structure. Lastly, my aim was to compare the functional properties of these chromatin species. I conceived a transcriptional read-out assay that would enable me to detect whether an immediate activating or repressing function is introduced by the chromatin assembly pathways.

The work presented here is the first attempt to compare both chromatin assembly pathways side-by-side in Xenopus laevis egg extracts on a biochemical, structural and functional level. The potential insights gained from such a study could substantially improve our understanding of chromatin assembly and thus epigenetic phenomena. 


\section{Material and Methods}

\subsection{Material and reagents}

\subsubsection{Laboratory equipment}

Commonly used laboratory equipment is listed in Table 2.1 .

Table 2.1 | Commonly used equipment.

\begin{tabular}{|c|c|c|c|}
\hline Equipment & Supplier & Equipment & Supplier \\
\hline $\begin{array}{l}\text { ÄKTA Explorer/ } \\
\text { Purifier/ FPLC System }\end{array}$ & $\begin{array}{l}\text { GE Healthcare, } \\
\text { Buckinghamshire (UK) }\end{array}$ & MiniTrans-Blot & Bio-Rad, München \\
\hline Balances & Mettler-Toledo, Giessen & Multitron shaker & $\begin{array}{l}\text { HT Infors, } \\
\text { Braunschweig }\end{array}$ \\
\hline $\begin{array}{l}\text { Centrifuge Sorvall } \\
\text { Discovery M } 150\end{array}$ & $\begin{array}{l}\text { Thermo Scientific, } \\
\text { Braunschweig }\end{array}$ & NanoDrop ND-1000 & Peqlab, Erlangen \\
\hline $\begin{array}{l}\text { Centrifuge Sorvall } \\
\text { Evolution RC }\end{array}$ & $\begin{array}{l}\text { Thermo Scientific, } \\
\text { Braunschweig }\end{array}$ & $\begin{array}{l}\text { NuPAGE Pre-cast } \\
\text { system }\end{array}$ & Invitrogen, Karlsruhe \\
\hline $\begin{array}{l}\text { Centrifuges } 5415 \mathrm{R} / \\
5810 \mathrm{R}\end{array}$ & Eppendorf, Hamburg & $\begin{array}{l}\text { PCR thermocycler } \\
\text { epgradientS }\end{array}$ & Eppendorf, Hamburg \\
\hline $\begin{array}{l}\text { EmulsiFlex-C5 High } \\
\text { Pressure Homogenizer }\end{array}$ & $\begin{array}{l}\text { Avestin, Ottawa } \\
\text { (Canada) }\end{array}$ & Peristaltic pump & $\begin{array}{l}\text { Ismatec, Glattbrugg } \\
\text { (Switzerland) }\end{array}$ \\
\hline $\begin{array}{l}\text { Gel documentation } \\
\text { system }\end{array}$ & Bio-Rad, München & $\mathrm{pH}$ meter & Mettler-Toledo, Giessen \\
\hline Gel dryer model 583 & Bio-Rad, München & $\begin{array}{l}\text { PhosphorImager, } \\
\text { Typhoon } 8600\end{array}$ & Molecular Dynamics \\
\hline Gene Pulser II & Bio-Rad, München & PlateChameleon & Hidex, Turku (Finland) \\
\hline $\begin{array}{l}\text { Gradient master model } \\
\text { 107ip }\end{array}$ & $\begin{array}{l}\text { BioComp, Fredericton } \\
\text { (Canada) }\end{array}$ & Power supplies & Bio-Rad, München \\
\hline $\begin{array}{l}\text { Heraues Kelvitron } \\
\text { Incubator }\end{array}$ & $\begin{array}{l}\text { Thermo Scientific, } \\
\text { Braunschweig }\end{array}$ & $\begin{array}{l}\text { SpeedVac Savant } \\
\text { SPD131DDA }\end{array}$ & $\begin{array}{l}\text { Thermo Scientific, } \\
\text { Braunschweig }\end{array}$ \\
\hline Hybridization oven & $\begin{array}{l}\text { GE Healthcare, } \\
\text { Buckinghamshire (UK) }\end{array}$ & Stuart Gyrorocker SSL3 & Sigma, Steinheim \\
\hline $\begin{array}{l}\text { Kodak X-Omat } 2000 \\
\text { processor }\end{array}$ & $\begin{array}{l}\text { Carestream Health, New } \\
\text { York (USA) }\end{array}$ & $\begin{array}{l}\text { Sub-Cell-GT Agarose } \\
\text { gel electrophoresis }\end{array}$ & Bio-Rad, München \\
\hline $\begin{array}{l}\text { Liquid Scintillation } \\
\text { Analyzer Tri-Carb } \\
\text { 2100TR }\end{array}$ & Packard, Meriden (USA) & Thermomixer comfort & Eppendorf, Hamburg \\
\hline $\begin{array}{l}\text { Orbitrap X1 mass } \\
\text { spectrometer }\end{array}$ & $\begin{array}{l}\text { Thermo Scientific, } \\
\text { Braunschweig }\end{array}$ & UV Transilluminator & Bio-Rad, München \\
\hline Mini-PROTEAN 3 cells & Bio-Rad, München & Waterbath TW12 & Julabo, Seelbach \\
\hline
\end{tabular}




\subsubsection{Chemicals}

Chemicals used for preparation of buffers and media are summarized in Table 2.2. All other chemicals not listed were purchased from Merck, Roth or Sigma.

Table 2.2 | Chemicals used for preparation of buffers and media.

\begin{tabular}{|c|c|c|c|}
\hline Chemical & Supplier & Chemical & Supplier \\
\hline 2-Mercaptoethanol & Sigma, Steinheim & Leupeptin & Sigma, Steinheim \\
\hline 2X YT medium & Roth, Karlsruhe & Magnesium chloride & Merck, Mannheim \\
\hline Acetyl Coenzyme A & Roche, Mannheim & Magnesium sulfate & Roth, Karlsruhe \\
\hline $\begin{array}{l}\text { Acrylamide/ Bisacrylamide } \\
\text { solution }(37.5: 1)\end{array}$ & Merck, Mannheim & Manganese chloride & Roth, Karlsruhe \\
\hline $\begin{array}{l}\text { Adenosine 5'-triphosphate, } \\
\text { disodium salt (ATP) }\end{array}$ & Sigma, Steinheim & Milk powder & $\begin{array}{l}\text { Régilait, Saint- } \\
\text { Martin-Belle-Roche } \\
\text { (France) }\end{array}$ \\
\hline Agar & Roth, Karlsruhe & $\begin{array}{l}\text { N-2-Hydroxyethylpipera- } \\
\text { zine-N'-2-ethansulphonic } \\
\text { acid (HEPES) }\end{array}$ & VWR, Poole (UK) \\
\hline Agarose & Serva, Heidelberg & N-Lauroylsarcosinat (30\%) & $\begin{array}{l}\text { AppliChem, } \\
\text { Darmstadt }\end{array}$ \\
\hline $\begin{array}{l}\text { Ammonium persulfate } \\
\text { (APS) }\end{array}$ & $\begin{array}{l}\text { AppliChem, } \\
\text { Darmstadt }\end{array}$ & Nonidet P-40 (NP-40) & Roche, Mannheim \\
\hline Ampicillin & $\begin{array}{l}\text { AppliChem, } \\
\text { Darmstadt }\end{array}$ & $\begin{array}{l}\text { Nucleoside-5' } \text {-triphosphate } \\
\text { (ATP, CTP, GTP, UTP) }\end{array}$ & Roth, Karlsruhe \\
\hline Benzamidine hydrochloride & Sigma, Steinheim & Polyethylene glycol 6000 & Merck, Mannheim \\
\hline Boric acid & Merck, Mannheim & Polyethylene glycol 8000 & Sigma, Steinheim \\
\hline Bovine serum albumin & Sigma, Steinheim & Pepstatin A & Sigma, Steinheim \\
\hline Bromophenol Blue & Serva, Heidelberg & $\begin{array}{l}\text { Phenylmethanesulfonyl } \\
\text { fluorid (PMSF) }\end{array}$ & Sigma, Steinheim \\
\hline Calcium chloride & Roth, Karlsruhe & Phosphocreatine, di(tris) salt & Sigma, Steinheim \\
\hline Chloramphenicol & $\begin{array}{l}\text { Amresco, Solon } \\
\text { (USA) }\end{array}$ & Ponceau S & Sigma, Steinheim \\
\hline Chloroform & Merck, Mannheim & $\begin{array}{l}\text { Phenol/Chloroform/Isoamyla } \\
\text { lcohol }\end{array}$ & Roth, Karlsruhe \\
\hline Chymostatin & Sigma, Steinheim & Rotiphorese Gel 40 & Roth, Karlsruhe \\
\hline Coomassie Brilliant Blue & Bio-Rad, München & Rotiphorese Gel A & Roth, Karlsruhe \\
\hline Cycloheximide & $\begin{array}{l}\text { AppliChem, } \\
\text { Darmstadt }\end{array}$ & Rotiphorese Gel B & Roth, Karlsruhe \\
\hline Cytochalasin B & Sigma, Steinheim & $\begin{array}{l}\text { S-(5'-Adenosyl)-L- } \\
\text { homocysteine (SAH) }\end{array}$ & Sigma, Steinheim \\
\hline $\begin{array}{l}\text { Deoxynucleoside- } 5^{\prime} \text { - } \\
\text { triphosphate (dATP, dCTP, } \\
\text { dGTP, dTTP) }\end{array}$ & Roth, Karlsruhe & $\begin{array}{l}\text { S-(5'-Adenosyl)-L- } \\
\text { methionine (SAM) }\end{array}$ & $\begin{array}{l}\text { New England } \\
\text { Biolabs, Frankfurt }\end{array}$ \\
\hline
\end{tabular}




\begin{tabular}{|c|c|c|c|}
\hline Dimethylsulfoxid (DMSO) & Sigma Steinheim & $\begin{array}{l}\text { Sodium dodecyl sulfate } \\
\text { (SDS), ultra pure }\end{array}$ & Roth, Karlsruhe \\
\hline Dithiothreithol (DTT) & $\begin{array}{l}\text { AppliChem, } \\
\text { Darmstadt }\end{array}$ & Sucrose & $\begin{array}{l}\text { Calbiochem/Merck, } \\
\text { Mannheim }\end{array}$ \\
\hline Ethidium bromide solution & Roth, Karlsruhe & $\begin{array}{l}\text { Tetramethylethylendiamine } \\
\text { (TEMED) }\end{array}$ & Sigma, Steinheim \\
\hline $\begin{array}{l}\text { Ethylenediamine tetraacetate } \\
\text { (EDTA) }\end{array}$ & Roth, Karlsruhe & Tetracycline & Roth, Karlsruhe \\
\hline Glucose & Merck, Mannheim & Thiamine hydrochloride & Sigma, Steinheim \\
\hline Glycerol & Merck, Mannheim & Trichostatin A & $\begin{array}{l}\text { Cell Signaling, } \\
\text { Ibswich (USA) }\end{array}$ \\
\hline Glycogen & $\begin{array}{l}\text { Fermentas, St. Leon- } \\
\text { Rot }\end{array}$ & Triethanolamine & VWR, Poole (UK) \\
\hline Guanidine Hydrochlorid & Sigma, Steinheim & $\begin{array}{l}\text { Tris(hydroxymethyl)amino- } \\
\text { methane (Tris base) }\end{array}$ & Roth, Karlsruhe \\
\hline $\begin{array}{l}\text { Human chorionic } \\
\text { gonadotropin (HCG) }\end{array}$ & Sigma, Steinheim & Triton $\mathrm{X}-100$ & Merck, Mannheim \\
\hline $\begin{array}{l}\text { Isopropyl- } \beta \text {-D-thiogalacto- } \\
\text { pyranoside (IPTG) }\end{array}$ & $\begin{array}{l}\text { AppliChem, } \\
\text { Darmstadt }\end{array}$ & Tryptone/Peptone & Roth, Karlsruhe \\
\hline Imidazol & Roth, Karlsruhe & Tween 20 & Sigma, Steinheim \\
\hline Kanamycin & $\begin{array}{l}\text { Amresco, Solon } \\
\text { (USA) }\end{array}$ & Urea & Merck, Mannheim \\
\hline LB Broth & MOBIO, Hamburg & Yeast extract & MOBIO, Hamburg \\
\hline L-cysteine hydrochloride & $\begin{array}{l}\text { AppliChem, } \\
\text { Darmstadt }\end{array}$ & $\beta$-glycerophosphate & $\begin{array}{l}\text { AppliChem, } \\
\text { Darmstadt }\end{array}$ \\
\hline
\end{tabular}

\subsubsection{Radiochemicals}

Radiochemicals were obtained from Perkin Elmer, Waltham (USA).

$\left[\alpha-{ }^{32} \mathrm{P}\right] \mathrm{CTP}$

$\left[\alpha-{ }^{32} \mathrm{P}\right] \mathrm{dATP}$

Adenosyl-L-methionine, S-[methyl- ${ }^{3} \mathrm{H}$ ]
$3000 \mathrm{Ci} / \mathrm{mmol}, 10 \mathrm{mCi} / \mathrm{ml}$ $3000 \mathrm{Ci} / \mathrm{mmol}, 10 \mathrm{mCi} / \mathrm{ml}$ $10 \mathrm{Ci} / \mathrm{mmol}$ 
2.1.4. Commonly used buffers and solutions

\begin{tabular}{|c|c|c|}
\hline $\begin{array}{l}10 X D N A \text { loading } \\
\text { dye }\end{array}$ & $\begin{array}{c}30 \%[\mathrm{v} / \mathrm{v}] \\
10 \mathrm{mM} \\
0.25 \%[\mathrm{w} / \mathrm{v}]\end{array}$ & $\begin{array}{l}\text { glycerol } \\
\text { EDTA } \\
\text { Bromophenol blue }\end{array}$ \\
\hline $10 X$ ELB salts & $\begin{array}{r}25 \mathrm{mM} \\
500 \mathrm{mM} \\
100 \mathrm{mM}\end{array}$ & $\begin{array}{l}\mathrm{MgCl}_{2} \\
\mathrm{KCl} \\
\mathrm{HEPES}-\mathrm{KOH} \mathrm{pH} 7.7\end{array}$ \\
\hline $10 X M M R$ & $\begin{array}{r}1 \mathrm{M} \\
20 \mathrm{mM} \\
5 \mathrm{mM} \\
25 \mathrm{mM} \\
1 \mathrm{mM} \\
50 \mathrm{mM}\end{array}$ & $\begin{array}{l}\mathrm{NaCl} \\
\mathrm{KCl} \\
\mathrm{MgSO}_{4} \\
\mathrm{CaCl}_{2} \\
\text { EDTA } \\
\text { HEPES-NaOH pH } 7.8\end{array}$ \\
\hline $10 X P B S$ & $\begin{array}{r}1.37 \mathrm{M} \\
27 \mathrm{mM} \\
100 \mathrm{mM} \\
20 \mathrm{mM}\end{array}$ & $\begin{array}{l}\mathrm{NaCl} \\
\mathrm{KCl} \\
\mathrm{Na}_{2} \mathrm{HPO}_{4} \\
\mathrm{KH}_{2} \mathrm{PO}_{4}\end{array}$ \\
\hline $\begin{array}{l}10 X R N A \text { loading } \\
\text { dye }\end{array}$ & $\begin{array}{c}80 \%[\mathrm{v} / \mathrm{v}] \\
10 \mathrm{mM} \\
0.25 \%[\mathrm{w} / \mathrm{v}] \\
0.25 \%[\mathrm{w} / \mathrm{v}]\end{array}$ & $\begin{array}{l}\text { formamide } \\
\text { Tris-HCl pH } 7.6 \\
\text { Xylene cyanol } \\
\text { Bromophenol blue }\end{array}$ \\
\hline $\begin{array}{l}\text { 10X SDS running } \\
\text { buffer }\end{array}$ & $\begin{array}{l}250 \mathrm{mM} \\
1.92 \mathrm{M} \\
1 \%[\mathrm{w} / \mathrm{v}]\end{array}$ & $\begin{array}{l}\text { Tris base } \\
\text { glycine } \\
\text { SDS }\end{array}$ \\
\hline $10 X T E$ & $\begin{array}{r}100 \mathrm{mM} \\
10 \mathrm{mM}\end{array}$ & $\begin{array}{l}\text { Tris-HCl pH } 8.0 \\
\text { EDTA-NaOH pH } 8.0\end{array}$ \\
\hline $10 X T B E$ & $\begin{array}{r}890 \mathrm{mM} \\
890 \mathrm{mM} \\
20 \mathrm{mM}\end{array}$ & $\begin{array}{l}\text { Tris base } \\
\text { boric acid } \\
\text { EDTA-NaOH pH } 8.0\end{array}$ \\
\hline $\begin{array}{l}2 X \text { SDS sample } \\
\text { buffer }\end{array}$ & $\begin{array}{c}62.5 \mathrm{mM} \\
20 \%[\mathrm{v} / \mathrm{v}] \\
2 \%[\mathrm{w} / \mathrm{v}] \\
0.1 \%[\mathrm{v} / \mathrm{v}] \\
0.1 \%[\mathrm{w} / \mathrm{v}]\end{array}$ & $\begin{array}{l}\text { Tris-HCl pH } 6.8 \\
\text { glycerol } \\
\text { SDS } \\
\text { 2-mercaptoethanol } \\
\text { Bromophenol blue }\end{array}$ \\
\hline $5 X M 9$ salts ( 1 l l) & $\begin{array}{r}64 \mathrm{~g} \\
15 \mathrm{~g} \\
2.5 \mathrm{~g} \\
5 \mathrm{~g}\end{array}$ & $\begin{array}{l}\mathrm{Na}_{2} \mathrm{HPO}_{4} \cdot 7 \mathrm{H}_{2} \mathrm{O} \\
\mathrm{KH}_{2} \mathrm{PO}_{4} \\
\mathrm{NaCl} \\
\mathrm{NH}_{4} \mathrm{Cl}\end{array}$ \\
\hline
\end{tabular}




\begin{tabular}{|c|c|c|}
\hline $5 X$ Reaction mix & $\begin{array}{r}200 \mathrm{mM} \\
25 \mathrm{mM} \\
2.5 \mathrm{mM} \\
200 \mathrm{mM}\end{array}$ & $\begin{array}{l}\text { HEPES-KOH pH } 7.8 \\
\mathrm{MgCl}_{2} \\
\text { DTT } \\
\text { phosphocreatine }\end{array}$ \\
\hline $50 X T A E(1 l)$ & $\begin{array}{l}242 \mathrm{~g} \\
57.1 \mathrm{ml} \\
37.2 \mathrm{~g}\end{array}$ & $\begin{array}{l}\text { Tris base } \\
\text { glacial acetic acid } \\
\text { EDTA }\end{array}$ \\
\hline $\begin{array}{l}\text { Coomassie staining } \\
\text { solution }\end{array}$ & $\begin{array}{l}0.1 \%[\mathrm{w} / \mathrm{v}] \\
10 \%[\mathrm{v} / \mathrm{v}] \\
50 \%[\mathrm{v} / \mathrm{v}]\end{array}$ & $\begin{array}{l}\text { Coomassie Brilliant Blue R250 } \\
\text { acetic acid } \\
\text { methanol }\end{array}$ \\
\hline Destaining solution & $\begin{array}{l}10 \%[\mathrm{v} / \mathrm{v}] \\
7.5 \%[\mathrm{v} / \mathrm{v}]\end{array}$ & $\begin{array}{l}\text { acetic acid } \\
\text { methanol }\end{array}$ \\
\hline$L B$ agar plates & $\begin{array}{l}25 \mathrm{~g} / 1 \\
1.5 \%[\mathrm{w} / \mathrm{v}]\end{array}$ & $\begin{array}{l}\text { LB broth } \\
\text { agar }\end{array}$ \\
\hline
\end{tabular}

\subsubsection{Commercial kits}

Commercial kits used in this study are listed in Table 2.3.

Table 2.3 | Commercial kits.

\begin{tabular}{ll}
\hline Kit & Supplier \\
\hline \hline Coomassie Plus (Bradford) Protein Assay & Pierce/Thermo Scientific, Rockford (USA) \\
ECL Plus Western Blotting Detection System & GE Healthcare, Buckinghamshire (UK) \\
ECL Western Blotting Detection Reagent & GE Healthcare, Buckinghamshire (UK) \\
NucleoBond PC 10000 & Machery\&Nagel, Düren \\
NucleoBond Xtra Midi Plus & Machery\&Nagel, Düren \\
NucleoSpin Extract II & Machery\&Nagel, Düren \\
NucleoSpin Plasmid & Machery\&Nagel, Düren \\
QiaPrep Spin M13 Kit & Qiagen, Hilden \\
QIAquick PCR purification kit & Qiagen, Hilden \\
RNeasy Mini Kit & Qiagen, Hilden \\
TNT Quick Coupled Transcription/Translation & Promega, Mannheim \\
System & \\
\hline
\end{tabular}




\subsubsection{Consumables and chromatographic material}

Table 2.4 | Consumables and chromatographic materials.

\begin{tabular}{ll}
\hline Consumables & Supplier \\
\hline \hline 1 Kb Plus DNA ladder & Invitrogen, Karlsruhe \\
96 well polystyrene plate, black, flat bottom & Corning, Corning (USA) \\
Amberlite MB3 resin & Merck, Mannheim \\
Amersham Hyperfilm ECL & GE Healthcare, Buckinghamshire (UK) \\
Amicon Ultra centrifugal filter devices (MWCO & Millipore, Billerica (USA) \\
$3,10,30$ kDa) & \\
Dynabeads M-280 sheep anti-rabbit IgG & Dynal Biotech/Invitrogen, Karlsruhe \\
Electroporation cuvettes & Bio-Rad, München \\
EN ${ }^{3}$ HANCE & Perkin Elmer, Waltham (USA) \\
Glutathione Sepharose 4 Fast Flow & GE Healthcare, Buckinghamshire (UK) \\
HiLoad 16/60 Superdex200 & GE Healthcare, Buckinghamshire (UK) \\
Kodak BioMax MR film & Carestream Health, New York (USA) \\
M13K07 helper phage & Invitrogen, Karlsruhe \\
MagneGST glutathione particles & Pierce/Thermo Scientific, Rockford (USA) \\
Ni' ${ }^{2+}$-NTA agarose & Qiagen, Hilden \\
Nitrocllulose membrane & GE Healthcare, Buckinghamshire (UK) \\
PD-10 columns & GE Healthcare, Buckinghamshire (UK) \\
Phase lock gel heavy tubes (2 ml, 15 ml, 50 ml) & 5PRIME, Hamburg \\
Q-Sepharose XK26/20 & GE Healthcare, Buckinghamshire (UK) \\
SeeBlue Plus2 prestained protein standard & Invitrogen, Karlsruhe \\
Sephacryl S-200 XK50/100 & GE Healthcare, Buckinghamshire (UK) \\
Slide-A-Lyzer dialysis units (MWCO 3,500 and & Pierce/Thermo Scientific, Rockford (USA) \\
10,000; volume 0.5 ml) & \\
Spectra/Por Dialysis Membrane (MWCO 3,500 & Spectrum Laboratories, Rancho Dominguez \\
and 6-8,000) & (USA) \\
SP-Sepharose XK26/20 & GE Healthcare, Buckinghamshire (UK) \\
Storage Phosphor Screens & GE Healthcare, Buckinghamshire (UK) \\
TALON metal affinity beads & Clontech, Mountain View (USA) \\
\hline
\end{tabular}




\subsubsection{Antisera and monoclonal antibodies}

Antibodies used for Western blot and immunoprecipitation are listed in Table 2.5.

Table 2.5 Antisera and antibodies used for Western blotting (WB) and immunoprecipitation (IP).

\begin{tabular}{|c|c|c|c|}
\hline Name & Host & Supplier, Catalog number & Dilution \\
\hline \multicolumn{4}{|c|}{ primary antibodies } \\
\hline$\alpha-B 4$ & rabbit, polyclonal & $\begin{array}{l}\text { Stefan Dimitrov, Institut Albert } \\
\text { Bonniot, La Tronche (France) }\end{array}$ & $1: 800$ \\
\hline$\alpha$-FLAG M2 & mouse, monoclonal & Sigma Aldrich, F1804 & $1: 1,000$ \\
\hline$\alpha-\mathrm{GST}$ & mouse, monoclonal & SantaCruz, sc-138 & $1: 500$ \\
\hline$\alpha-\mathrm{H} 2 \mathrm{~A} . \mathrm{Z}$ & rabbit, polyclonal & abcam, ab4174 & $1: 1000$ \\
\hline$\alpha-\mathrm{H} 3$ & rabbit, polyclonal & abcam, ab1791 & $1: 20,000$ \\
\hline$\alpha-\mathrm{H} 3 \mathrm{ac}$ & rabbit, polyclonal & upstate/Millipore, 06-599 & $1: 10,000$ \\
\hline$\alpha-\mathrm{H} 3 \mathrm{~K} 4 \mathrm{me} 1$ & rabbit, polyclonal & abcam, ab8895 & $1: 1,000$ \\
\hline$\alpha-\mathrm{H} 3 \mathrm{~K} 4 \mathrm{me} 2$ & rabbit, polyclonal & abcam, ab32356 & $1: 1,000$ \\
\hline$\alpha-\mathrm{H} 3 \mathrm{~K} 4 \mathrm{me} 3$ & rabbit, polyclonal & active motif, 39159 & $1: 2,000$ \\
\hline$\alpha-\mathrm{H} 3 \mathrm{~K} 9 \mathrm{me} 3$ & rabbit, polyclonal & upstate/Millipore, 07-442 & $1: 1,000$ \\
\hline$\alpha-\mathrm{H} 3 \mathrm{~K} 27 \mathrm{me} 3$ & rabbit, polyclonal & active motif, 39155 & $1: 1,000$ \\
\hline$\alpha-\mathrm{H} 3 \mathrm{~K} 36 \mathrm{me} 2$ & rabbit, polyclonal & upstate/Millipore, 07-274 & $1: 1,000$ \\
\hline$\alpha-\mathrm{H} 3 \mathrm{~K} 79 \mathrm{me} 2$ & rabbit, polyclonal & upstate/Millipore, 07-312 & $1: 1,000$ \\
\hline$\alpha-\mathrm{H} 4$ & rabbit, polyclonal & upstate/Millipore, 07-108 & $1: 500$ \\
\hline$\alpha-\mathrm{H} 4 \mathrm{ac}$ & rabbit, polyclonal & upstate/Millipore, 06-946 & $1: 10,000$ \\
\hline$\alpha-\mathrm{H} 4 \mathrm{~K} 5 \mathrm{ac}$ & rabbit, polyclonal & upstate/Millipore, 07-327 & $1: 50,000$ \\
\hline$\alpha-\mathrm{H} 4 \mathrm{~K} 12 \mathrm{ac}$ & rabbit, polyclonal & upstate/Millipore, 07-595 & $1: 20,000$ \\
\hline$\alpha-\mathrm{H} 4 \mathrm{~K} 20 \mathrm{me} 1$ & rabbit, polyclonal & upstate/Millipore, 05-735 & $1: 1,000$ \\
\hline$\alpha-\mathrm{H} 4 \mathrm{~K} 20 \mathrm{me} 2$ & rabbit, polyclonal & upstate/Millipore, 07-367 & $1: 1,000$ \\
\hline$\alpha-\mathrm{H} 4 \mathrm{~K} 20 \mathrm{me} 3$ & rabbit, polyclonal & upstate/Millipore, 07-463 & $1: 1,000$ \\
\hline$\alpha-\mathrm{His}_{6}$-HRP & mouse, monoclonal & Roche, 11965085001 & $1: 1,000$ \\
\hline$\alpha$-xHIRA & rabbit, polyclonal & $\begin{array}{l}\text { Genevieve Almouzni, Institute } \\
\text { Curie, Paris (France) }\end{array}$ & $\begin{array}{l}1: 10,000(\mathrm{WB}) \\
3-5 \mu 1(\mathrm{IP})\end{array}$ \\
\hline \multicolumn{4}{|c|}{ secondary antibodies } \\
\hline$\alpha$-mouse HRP & goat, polyclonal & Dako, P0447 & $1: 5,000$ \\
\hline$\alpha$-rabbit HRP & swine, polyclonal & Dako, P0399 & $1: 5,000$ \\
\hline
\end{tabular}




\subsubsection{Enzymes, proteins and inhibitors}

Commonly used enzymes, proteins and inhibitors are listed in Table 2.6.

Table 2.6 | Commonly used enzymes, proteins and inhibitors.

\begin{tabular}{ll}
\hline Enzyme & Supplier \\
\hline \hline Antarctic phosphatase & New England Biolabs, Frankfurt \\
Aphidicolin & Sigma, Steinheim \\
Creatine kinase & Roche, Mannheim \\
DNaseI & New England Biolabs, Frankfurt \\
GAL4-VP16 & Jena Bioscience, Jena \\
Micrococcal nuclease & Calbiochem, Merck, Darmstadt \\
Nuclease S1 & Fermentas, St. Leon-Rot \\
p300 acetyltransferase & purified by Adrian Schomburg \\
PfuUltra II Fusion HS polymerase & Stratagene, La Jolla (USA) \\
Proteinase K & Roche, Mannheim \\
Restriction enzymes & New England Biolabs, Frankfurt \\
RNase A & Sigma, Steinheim \\
RNase T1 & Roche, Mannheim \\
RNasin, RNase inhibitor & Promega, Mannheim \\
TEV protease & purified by Winfried Lendeckel \\
T4 DNA ligase & New England Biolabs, Frankfurt \\
\hline
\end{tabular}

\subsubsection{Oligonucleotides}

Oligonucleotides were designed using the DNASTAR Lasergene 7 program and purchased from Eurofins MWG Operon (Ebersberg). The restriction sites are underlined.

Primers for cloning

\begin{tabular}{|c|c|c|}
\hline PRSet7-BamHI-for & 5 & ACTTGCGGATCCATGGGAAGAGGGAAGAAAATG 3' \\
\hline PRSet7-NotI-rev & 5 & СCTCTTGAGCGGCCGCGTTTTTAAGCCAAGGATGTGC 3' \\
\hline PRSet7-BamHI-rev & 5 , & TTGCCTGGATCCGTTTTTAAGCCAAGGATGTGC 3’ \\
\hline HIRA-NotI_for & 5 , & ACTTGCGCGGCCGCATGAAGCTCCTGAAACCAAG 3' \\
\hline HIRA-NotI_rev & 5 , & ССТCTTGAGCGGCCGCTTTGTCССTCAAAATGTCCAAC 3, \\
\hline
\end{tabular}


Scavenger DNA primers

scavenger-for

5' GTTATCCGCTCACAATTCCACACAACATAC 3'

scavenger-rev

5' TAATGCAGCTGGCACGACAGGTTTC 3'

Sequencing primers

Hira-internal-for

5' CAtCGCAAAGCTGTCACG 3'

Hira-internal-rev

5' GCTGCTGCTACGATTCG 3'

\subsubsection{Plasmids}

The plasmids used for cloning, chromatin assembly and protein expression are listed in Table 2.7 .

Table 2.7 | Plasmids used for cloning, heterologous protein expression and chromatin reconstitution.

\begin{tabular}{|c|c|c|c|c|c|}
\hline Name & Promoter & Selection & Tags & Application & Supplier \\
\hline $\begin{array}{l}\text { M13mp } 18 \\
\text { (ds/ss form) }\end{array}$ & lac & - & - & $\begin{array}{l}\text { phage, } \\
\text { reconstitution }\end{array}$ & $\begin{array}{l}\text { New England Biolabs, } \\
\text { Frankfurt }\end{array}$ \\
\hline $\begin{array}{l}\text { pBluescriptII } \\
\text { SK(-) }\end{array}$ & $\mathrm{T} 7 / \mathrm{T} 3$ & Ampicillin & - & $\begin{array}{l}\text { phagemid, } \\
\text { cloning }\end{array}$ & Fermentas, St. Leon-Rot \\
\hline pBS_G ${ }_{5} \mathrm{ML}$ & $\mathrm{T} 7 / \mathrm{T} 3$ & Ampicillin & - & $\begin{array}{l}\text { phagemid, } \\
\text { reconstitution, } \\
\text { transcription }\end{array}$ & $\begin{array}{l}\text { Alexandra Stützer/ } \\
\text { Wolfgang Fischle, MPI } \\
\text { bpc Göttingen }\end{array}$ \\
\hline $\begin{array}{l}\text { pcDNA } 3.1(+)- \\
\text { FlF1-HAHA }\end{array}$ & $\mathrm{T} 7 / \mathrm{CMV}$ & Ampicillin & $\begin{array}{l}\text { C-terminal } \\
\text { double FLAG, } \\
\text { double HA }\end{array}$ & $\begin{array}{l}\text { expression } \\
\text { vector }\end{array}$ & $\begin{array}{l}\text { Nora Köster-Eisefunke/ } \\
\text { Wolfgang Fischle, MPI } \\
\text { bpc Göttingen [129] }\end{array}$ \\
\hline pET16b & $\mathrm{T} 7$ & Ampicillin & N-terminal His & $\begin{array}{l}\text { expression } \\
\text { vector }\end{array}$ & $\begin{array}{l}\text { Novagen/Merck, } \\
\text { Mannheim }\end{array}$ \\
\hline $\begin{array}{l}\text { pET3a_H3/H4/ } \\
\mathrm{H} 2 \mathrm{~A} / \mathrm{H} 2 \mathrm{~B}\end{array}$ & $\mathrm{~T} 7$ & Ampicillin & - & $\begin{array}{l}\text { expression } \\
\text { vector }\end{array}$ & $\begin{array}{l}\text { Karolin Luger, Colorado } \\
\text { State Univ., Fort Collins } \\
\text { (USA) }\end{array}$ \\
\hline $\mathrm{pG}_{5} \mathrm{ML}$ & AdML & Ampicillin & - & transcription & $\begin{array}{l}\text { Woojin An, USC (USA) } \\
{[130]}\end{array}$ \\
\hline pGEX4T3 & $\mathrm{T} 7$ & Ampicillin & $\begin{array}{l}\text { N-terminal } \\
\text { GST }\end{array}$ & $\begin{array}{l}\text { expression } \\
\text { vector }\end{array}$ & $\begin{array}{l}\text { GE Healthcare, } \\
\text { Buckinghamshire (UK) }\end{array}$ \\
\hline pRUTH-H3.3 & $\mathrm{T} 7$ & Kanamycin & $\begin{array}{l}\text { N-terminal } \\
\text { His }_{6} \text { and TEV } \\
\text { site }\end{array}$ & $\begin{array}{l}\text { expression } \\
\text { vector }\end{array}$ & $\begin{array}{l}\text { David Allis (Rockefeller } \\
\text { University, New York, } \\
\text { USA) }\end{array}$ \\
\hline $\begin{array}{l}\text { pUC18_12x200 } \\
\times 601\end{array}$ & $\mathrm{~T} 7$ & Ampicillin & - & $\begin{array}{l}\text { chromatin } \\
\text { array template }\end{array}$ & $\begin{array}{l}\text { Daniela Rhodes (MRC } \\
\text { Cambridge, UK) [9] }\end{array}$ \\
\hline $\begin{array}{l}\text { pUC18_52x187 } \\
\times 601\end{array}$ & $\mathrm{~T} 7$ & Ampicillin & - & $\begin{array}{l}\text { nucleosome } \\
\text { template }\end{array}$ & $\begin{array}{l}\text { Daniela Rhodes (MRC } \\
\text { Cambridge, UK) [131] }\end{array}$ \\
\hline pUC19 & $\mathrm{T} 7$ & Ampicillin & - & reconstitution & Invitrogen, Karlsruhe \\
\hline
\end{tabular}




\subsubsection{Bacterial strains and cell lines}

The Escherichia coli strain DH5 $\alpha$ was used for propagation of plasmid DNA, DH12S cells for preparation of ssDNA, XL1-Blue MRF' for production of helper phages and BL21-CodonPlus (DE3)-RIL cells were used for the heterologous expression of proteins.

Table 2.8 | Bacterial strains and their genotypes.

\begin{tabular}{|c|c|c|}
\hline Strain & Genotype & Supplier \\
\hline $\begin{array}{l}\text { BL21-CodonPlus } \\
\text { (DE3)-RIL }\end{array}$ & $\begin{array}{l}\text { E. coli } \mathrm{B} \mathrm{F}-\text { ompT hsdS(rB- mB-) dcm }+ \text { Tetr gal l (DE3) } \\
\text { endA The [argU ileY leuW Camr] }\end{array}$ & $\begin{array}{l}\text { Stratagene, La Jolla } \\
\text { (USA) }\end{array}$ \\
\hline DH12S & 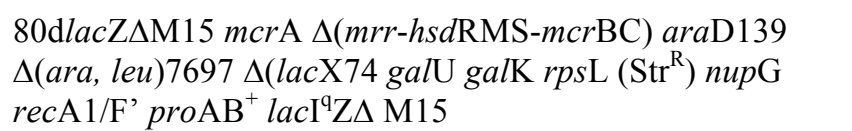 & Invitrogen, Karlsruhe \\
\hline DH5 $\alpha$ & $\begin{array}{l}\text { E. coli } \mathrm{F}-\mathrm{f} 80 \text { lacZDM15 D(lacZYA-argF) } \mathrm{U} 169 \text { deo } \mathrm{R} \\
\text { recA1 endA1 hsd } 17\left(\mathrm{rk}-, \mathrm{mk}^{+}\right) \text {phoAsup } 44 \text { 1-thi-1 gyrA96 } \\
\text { relA1 }\end{array}$ & Invitrogen, Karlsruhe \\
\hline XL1-Blue MRF' & $\begin{array}{l}\Delta(m c r A) 183 \Delta(\text { mcrCB-hsdSMR-mrr }) 173 \text { endA1 supE } 44 \\
\text { thi-1 recA1 gyrA96 relA1 lac }\left[F^{\prime} \text { proAB } \text { lac } \mathrm{I}^{\mathrm{q}} \mathrm{Z} \Delta \mathrm{M} 15 \operatorname{Tn} 10\right. \\
\left.\left(\mathrm{Tet}^{\mathrm{R}}\right)\right]\end{array}$ & $\begin{array}{l}\text { Stratagene, La Jolla } \\
\text { (USA) }\end{array}$ \\
\hline
\end{tabular}

HeLa S3 cells (Computer cell culture centre, Belgium) were kindly provided by Thomas Conrad and Hossein Kohansal (Lührmann department, Max Planck Institute for biophysical chemistry, Göttingen). 


\subsection{Molecular biology methods}

\subsubsection{Analysis of nucleic acids}

\subsubsection{Concentration determination of nucleic acids}

The concentration of nucleic acids was determined using a NanoDrop ND-1000 spectrophotometer at $260 \mathrm{~nm}$ against a reference. The following equations were used to calculate DNA concentrations [132]:

$1 \mathrm{OD}_{260 \mathrm{~nm}}=50 \mu \mathrm{g} / \mathrm{ml}$ double-stranded DNA

$1 \mathrm{OD}_{260 \mathrm{~nm}}=33 \mu \mathrm{g} / \mathrm{ml}$ single-stranded DNA

\subsubsection{Agarose gel electrophoresis}

DNA fragments were separated according to their size on $0.5 \%$ to $2 \%$ [w/v] agarose gels in a TBE or TAE buffer system [132]. Typically, $300 \mathrm{ng}$ DNA was mixed with DNA loading dye and gels were run for $45 \mathrm{~min}$ at 90-120 V at RT using a horizontal electrophoresis system (Bio-Rad). A 1 kb Plus DNA Ladder was included as a size reference. DNA was stained with $0.5 \mu \mathrm{g} / \mathrm{ml}$ ethidium bromide for $20 \mathrm{~min}$ at RT, destained for $30 \mathrm{~min}$ in $\mathrm{ddH}_{2} \mathrm{O}$ and visualized on a UV transilluminator.

\subsubsection{Native polyacrylamide gel electrophoresis of DNA (Native PAGE)}

Continuous native PAGE was used to analyze mononucleosome preparations [133135]. A $1.5 \mathrm{~mm}$ thick minigel contained $6 \%$ [w/v] acrylamide: bisacrylamide [29:1], 0.5X TBE, 0.1\% [w/v] APS and 0.04\% [v/v] TEMED. For loading 1 pmol [120 ng DNA] mononucleosomes were supplemented with 5\% glycerol. A DNA ladder and naked DNA were included in the gel as a size reference. The gel was run in the MiniPROTEAN 3 system (Bio-Rad) in $0.5 \mathrm{X}$ TBE for $90 \mathrm{~min}$ at $90 \mathrm{~V}$ at RT. The gel was stained for $15 \mathrm{~min}$ with $0.5 \mu \mathrm{g} / \mathrm{ml}$ ethidium bromide and destained for $20 \mathrm{~min}$ in $\mathrm{ddH}_{2} \mathrm{O}$.

\subsubsection{Denaturing polyacrylamide gel electrophoresis of RNA (Urea-PAGE)}

Radioactive RNA molecules were separated on denaturing polyacrylamide-urea gels. A $5 \%$ minigel ( $1.5 \mathrm{~mm}$ thickness) was poured and pre-run for $15 \mathrm{~min}$ at $10 \mathrm{~W}$ in $1 \mathrm{X}$ TBE in the Mini-PROTEAN 3 system. The RNA samples were dissolved in RNA loading dye, boiled for $3 \mathrm{~min}$ at $95^{\circ} \mathrm{C}$ and cooled on ice before loading into wellrinsed pockets. Electrophoresis was performed at $12 \mathrm{~W}$ for $30-35 \mathrm{~min}$ or until the 
Xylene cyanol dye was about $1 \mathrm{~cm}$ from the bottom of the gel. The radioactive RNA was visualized by autoradiography (2.4.7.3).

$5 \%$ polyacrylamide-urea gel:

$5 \%[\mathrm{w} / \mathrm{v}] \quad$ acrylamide:bisacrylamide (19:1) diluted from Gel 40

$8.3 \mathrm{M} \quad$ urea

$1 \mathrm{X} \quad \mathrm{TBE}$

$0.1 \%[\mathrm{w} / \mathrm{v}] \quad$ APS

$0.1 \%[\mathrm{v} / \mathrm{v}] \quad$ TEMED

\subsubsection{General cloning procedures}

\subsubsection{1. cDNA sequences}

The cDNA sequences for Xenopus laevis pr-set7 and hira were obtained as I.M.A.G.E Consortium clones through imaGenes (Berlin).

Xenopus laevis pr-set7 (setd8-a) cDNA that matched the annotated sequence BC124952 was obtained as I.M.A.G.E clone IRBHp990B0286D (ImageID 6317540): PR-Set7 (SETD8-a, 1005 bp)

ATGGGAAGAGGGAAGAAAATGTCCAAACCCGGCGACGGAAGGAGCGGGGACGTCTCGGA TACCGGCAGGAACGGCGGCACCAATGAAAATCATCCAAAAACGAACGGGGAGGTGGTTC ATTGTGGGCAGGCCAAAATCTACTCTTATATGAGCCCAACTAAATCTCCCAGTGCCCGCCC TCCCCTGCAAGAAGAAAACTCTGTTACGCACCATGAGAGCAAGTGTCTGGGGAAACCCTC AACAGAGACTCGCAAAAAAGCAGAGGTTGAGAAAAAGAAAATATTGTCAACAGAACTGT CGGTGAAACCCAGTGAGCAAAGGGAGACTGAATGCAATTCTATAGGAGAGTTTCTTGAGC CAAAACTAGAGCTGAATGATGTACAGAGAAACCTAGCATTGCCACCTGAAGACAAGCTGC AATCTCAAAAGATGGTTAAAAACAAACCTCTAAGAAAGAAGACTCAAAGGCAGAAATCT CCAAATAGAAAACTTACTGATTATTACCCTGTGAGAAGAAGCAGCAGGAAGAATAAAAC AGAAATTGAGTCAGAGGAGAAGAAGAGAATAGATGAACTAATTCAGACTGGCAAAGAAG AAGGGATAAAGATGCACATGATTACTGGGAAAGGGCGAGGTGTAATTGCAACTCGGGAC TTCCAGCGAGGAGAGTTTGTTGTAGAATACCATGGAGATCTGATAGAGATCACGGATGCC AAAAGGAGAGAAGCATCATATGCACAGGATTCAGCTACTGGCTGCTATATGTACTATTTT CAGTATTTGAACACAAGCTACTGCATCGATGCCACAAGAGAGACTGGCCGTTTAGGGAGG CTGATCAACCACAGCAAGTCTGGAAACTGTCACACCAAACTGCACAACATCAACAATGTA CCTCACCTTATACTTGTTGCATCGCGGGATATCAACGTTGGAGAGGAATTGCTGTATGACT ATGGTGATAGAAGAAAATCTTCCATTGATGCACATCCTTGGCTTAAAAAC 
The I.M.A.G.E clone IRBHp990F1129D (ImageID 4959832) contained hira cDNA and matched the GenBank sequence BC078007.1:

HIRA (3039 bp)

ATGAAGCTCCTGAAACCAAGTTGGGTTAATCATAATGGCAAGCCCATTTTTTCAGTGGACA TTCACCCTGATGGCACAAAGTTTGCTACTGGAGGTCAAGGACAAGATTCTGGAAAAGTCG TTATCTGGAATATGCCTCCTATGCTTAAAGAGGAAGATGAAAAAAATGAAAATATTCCCA AGATGCTCTGCCAGATGGACAACCACTTAGCGTGCGTGAACTGCGTCCGGTGGTCCAACA ATGGAGCTTATTTAGCATCTGGAGGGGACGACAAGCTTATCATGGTGTGGAAACGATCAG GATACATTGGACCCAGCACTGTTTTTGGCTCCAGCAGCAAATTGGCTAATGTTGAGCAGTG GCGTTGTCTTTCCATTCTCAGAAGTCATTCTGGAGATGTGATGGACGTAGCATGGTCTCCC CATGATGCTTGGTTAGCTTCATGCAGTGTGGATAACACAGTGGTTATATGGAATGCCTTGA AATTCCCAGAGATCATTTCCACATTACGGGGCCACTCTGGGCTGGTAAAAGGACTAACAT GGGATCCTGTTGGCAAGTACATTGCTTCTCAGGCTGATGACCATAGCATCAAGGTTTGGAG GACCATGGACTGGCAACTAGAAACAAGCATCACTAAACCATTTGATGAATGTGGAGGAAC AACCCATGTCTTGCGACTTAGCTGGTCTCCAGATGGACATTACCTGGTATCGGCTCATGCC ATGAACAACTCTGGCCCCACGGCCCAAATCATTGAACGTGATGGCTGGAAGACAAACATG GACTTTGTGGGACATCGCAAAGCTGTCACGGTGGTGAAATTCAATCCAAAAATATTTAAG AAGAAACAAAAAAATGGTAGCTCCACAAAGACCAGCTGCCCTTACTGCTGCTGTGCTGTT GGAAGTAAGGATCGGTCCTTGTCAGTATGGCTCACTTGTCTCAAGAGGCCTTTGGTTGTAA TCCATGAACTTTTTGACAAATCCATAATGGACATCTCTTGGACTTTAAATGGGTTGGGCAT TTTGGTATGTTCTATGGATGGATCAGTTGCTTATCTCGATTTCTCCCAGGATGAGCTTGGTG ACCCATTAAGTGAGGAAGAGAAGAATAATATCCACCAAAGTACATACGGGAAGAGTCTG GCCATCACAACAGAGCCCCAGCTACCTAATACTGTTATAGAGAACCCAGAGATGCTGAAG TTCCAGCAGAGGCAGCAGCTGCAACAGGATGGGGAACATATGGTGCAAGCACAGATGGA GGCTCCTATTCATAACATGGCCAGCATGATGAATGGGGAAAGCTTGGAGGACATAAGAAA GAACCTCTTGAAAAAGCAAGTGGAGACACGAACAGCTGATGGACGGCGAAGGATCACTC CACTCTGCATTGCTCAGCTAGACACTGGGGACTTTTCCACAGCGTTTTTCAATAGTATTCC AATATCTGGTTCGCTTCCCGGCTCAATGATGTCTTCACAAAGCAACCAGCAGCTTATATCA TTGGATTCCAACACAACCAGCTCCTCTGGGGCTCTCAAGTCTAATGTGGAACTTGTAGGAA ATAACACAAAACCAGCCGAGGAAACAGCCAACAAAGAGAGCGGGAATGTTTCATCTTCC AGTCCTGTGGCGCCCACTAGCATCACTGCCCAGCCAAAGATTGAACCCATGAAGGCACTT GACTCCAGATTTACTGAACGTTCAAAAGCCACCTCAGGAACAGCAGGAGTTGCTCATTTG AACCAGACCGCTGTAGATCGACTAAAAGAGCAAAATGTTACAAAGGATTCAAAGCCACG AGTGGTTGAGAGCAGCAGTGACAGTGAGGAAAAGATTCCTGCATCCAAACAACTCTCCAA ACGAAAGGGGGAGGCTGATGCTGACCTTGCAGAGAAGAGGAAGAAAGGGAGGCCACGCA AAGAGTCGCAAAGACTAATGTCAGTCTCACTCACTGTGCAGTCTCAGGTGGCATCAACTTC TGAAAAGGAATTAACATGTGTAACGACATCCTCGTTAACCCTTCGGCTTCCAACCCCCACT CCTCAAAAATCTTTTACTTTACAGTTAAGCTCAGACCCTTCCATGTACATTGAAGTTGAGA ATGAAGTGAAAACAGTAGGTGGAAACAAACTCAGCCAGCTCAAGTGTCACCGAGAAGGA AAAGAATGGGAAGCGGTGCTCACAAGTCGAATCGTAGCAGCAGCAGGCAGCAAAGAGGT 
GGTGTGCGTGGCCTGCGAGAAAAGAATGTTGTCCATTTTCTCAGGCAGTGGAAGGAGAAT CTTCCCACCCATCATTCTTCССТCTCCTATTTCCACACTGCAGTGTACAGGATCCTATGTTA TGGCTCTCACAGCTGCTGCTGCTCTCTCTGTCTGGGATGTCCAGAACCAGAACATTATAAT CAAAAATGAATCTTTACAACCACTTTTATCAGGTAACGATTTGACTGTTTCTCAGACATTA CTGACAAAGAGAGGTATACCCGTGCTGAGTCTGTCCAATGGGAAAGCATATTGCTTCAGT CCCAGTCTTTCCACGTGGAGTCTGGTCTCTGACAAGCAGGATTCCTTGGCACAGTGTGCAG ATTACCGGAGCTGCATGCCCTCGCAGGATGCTGTCATGTGCTCTGGACCATTAGCCATAAT TCAAGGACGAGTGTCTAATGCTGGCAGACAGGCTGCTCACCTTTTCACGATGCCTCACCTT GTGCAGAAAGAAACCACCATGGCTTACCTTGAGAACCAGGTAGCAGCTGCTCTTATGCTG CAATCTAGCCAGGAATACAGGCACTGGTTGCTCATCTATGCACAATACCTGGTCAATGAA GGTTTTGAACAGAGGCTACGAGAAGTATGCCAGGACCTTCTAGGCCCTGTCCATCGTTCTA GTGATAGTCAATGGGAATCAAGAATTTTGGGTTTGTGGAAGAGAGAGCTATTGAAGGAGC TTCTTCCTCTGATTGGACAGAACCTGCGTTTTCAGCGACTTTTCACAGAGTACCAAGAGCA GTTGGACATTTTGAGGGACAAA

\subsubsection{Polymerase chain reaction (PCR)}

Specific cDNA sequences were amplified according to standard protocols [132] using a forward and reverse primer (2.1.9) containing the appropriate restriction sites for subsequent cloning steps. A standard PCR mix [50 $\mu \mathrm{l}]$ contained $50 \mathrm{ng}$ DNA, 1X PfuUltra II reaction buffer (supplied by the manufacturer), $0.2 \mathrm{mM}$ dNTPs (Roth), $0.2 \mu \mathrm{M}$ forward primer, $0.2 \mu \mathrm{M}$ reverse primer and $1 \mathrm{U}$ PfuUltra II Fusion HS DNA Polymerase (Stratagene). The reaction mix was incubated in an epgradientS PCR thermocycler according to the following program:

$\begin{array}{ll}\text { temperature } & \text { time } \\ 95^{\circ} \mathrm{C} & 2 \mathrm{~min} \\ 95^{\circ} \mathrm{C} & 30 \mathrm{~s} \\ 55-65^{\circ} \mathrm{C} & 30 \mathrm{~s} \\ 72^{\circ} \mathrm{C} & 15 \mathrm{~s} / \mathrm{kb} \mathrm{DNA} \\ 72^{\circ} \mathrm{C} & 5 \mathrm{~min} \\ 10^{\circ} \mathrm{C} & \infty\end{array}$

\subsubsection{Restriction digest and ligation of $\mathrm{DNA}$}

cDNA fragments amplified by PCR were purified with a nucleotide removal kit (NucleoSpin Extract II). The purified cDNA as well as the target vector were digested with the corresponding restriction nucleases (New England Biolabs) according to the manufacturer's instructions. The digest was followed by DNA separation on an agarose gel (2.2.1.2) and gel purification of DNA fragments (NucleoSpin Extract II). The target vector was dephosphorylated with Antarctic phosphatase as described in 
the manufacturer's protocol. For ligation of DNA fragments 50-100 ng of dephosphorylated vector were incubated with a 3-5-fold molar excess of DNA insert. The DNA mix was incubated in a total volume of $10 \mu \mathrm{l}$ with $1 \mathrm{X}$ ligase buffer (supplied by manufacturer), 3\% [w/v] PEG 6000 and $1 \mu 1$ T4 DNA ligase for $30 \mathrm{~min}$ at RT followed by transformation of competent bacteria.

\subsubsection{Transformation of competent bacteria}

Electrocompetent DH12S cells (Invitrogen) were transformed by electroporation according to the manufacturer's instructions using the Gene Pulser II electroporation system. Chemically competent bacteria were prepared by the $\mathrm{CaCl}_{2}$ method [132, 136] and transformed by heat shock. Therefore, $50 \mu 1$ bacteria were thawed on ice and incubated for $20 \mathrm{~min}$ with 5-10 $\mu \mathrm{l}$ ligation mix or $10 \mathrm{ng}$ of supercoiled plasmid DNA. The cells were heat-shocked for $45 \mathrm{~s}$ at $42^{\circ} \mathrm{C}$ in a waterbath and then cooled on ice for $2 \mathrm{~min}$. For cell recovery $500 \mu \mathrm{l}$ of prewarmed SOC medium (2\% tryptone, $0.5 \%$ yeast extract, $10 \mathrm{mM} \mathrm{NaCl}, 2.5 \mathrm{mM} \mathrm{KCl}, 20 \mathrm{mM}$ glucose) was added and the cells were incubated for $1 \mathrm{~h}$ at $37^{\circ} \mathrm{C}$ at $650 \mathrm{rpm}$ in a thermomixer. Successfully transformed cells were selected on LB-agar plates supplemented with the appropriate antibiotic. Final antibiotic concentrations were $100 \mu \mathrm{g} / \mathrm{ml}$ ampicillin, $50 \mu \mathrm{g} / \mathrm{ml}$ kanamycin, $34 \mu \mathrm{g} / \mathrm{ml}$ chloramphenicol or $12.5 \mu \mathrm{g} / \mathrm{ml}$ tetracycline.

\subsubsection{Sequence analysis of cloned constructs}

Single colonies were picked after transformation in $5 \mathrm{ml} \mathrm{LB}$ medium (supplemented with the appropriate antibiotic) and grown overnight at $37^{\circ} \mathrm{C}$ in a shaker. The cells were harvested by centrifugation and plasmid DNA was prepared using the NucleoSpin Plasmid kit. To screen for constructs carrying the correct insert, $500 \mathrm{ng}$ of each clone were digested with the corresponding restriction endonucleases and fragments were analyzed by agarose gel electrophoresis. Positive clones were sequenced by Seqlab laboratories (Göttingen). Seqlab provided all sequencing primers with the exception of the internal HIRA sequencing primers (2.1.9).

\subsubsection{Generation of the $p B S-G_{5} M L$ phagemid}

The $\mathrm{pG}_{5} \mathrm{ML}$ plasmid $[130,137]$ was kindly provided by Woojin An (USC, USA). It contains a $370 \mathrm{bp}$ long G-less cassette downstream of an adenovirus major late (AdML) promoter and five GAL4 upstream activator sequences (UAS). This insert is 
flanked by five 5SrDNA sequences on each site. For generation of the phagemid used in this study, only the G-less cassette, the AdML promoter and the GAL4-UAS sites were cut out with BamHI and PstI. The fragment was ligated via the same restriction sites into the pBluescriptII SK(-) vector. The phagemid was renamed pBS-G $\mathrm{G}_{5} \mathrm{ML}$.

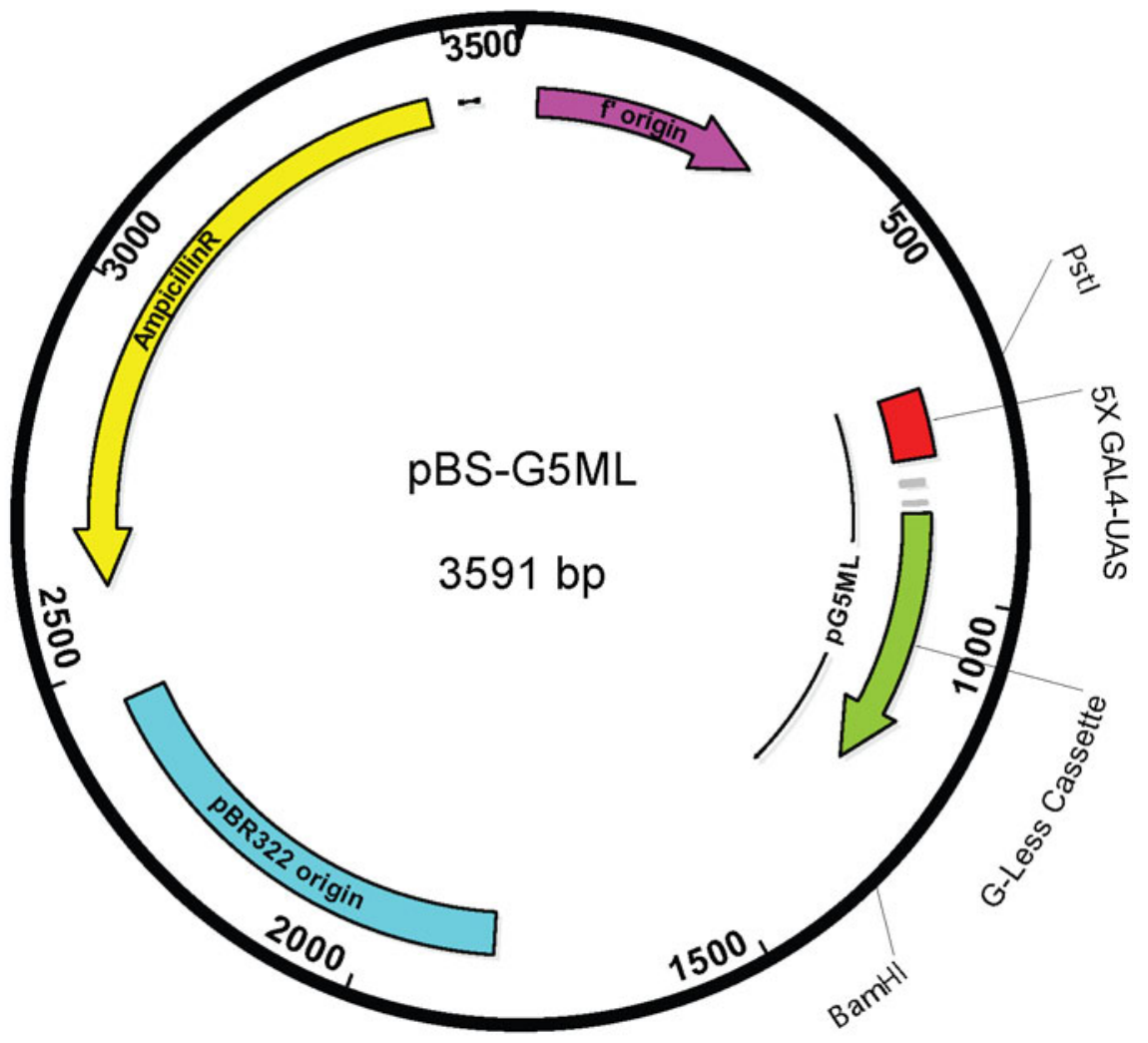

Figure 2.1 | Vector map of the pBS-G5 1 ML plasmid.

\subsubsection{Generation of expression constructs}

Sources and properties of the used plasmids are listed in Table 2.7. The oligonucleotide sequences employed for cloning can be found in 2.1.9. Table 2.9 gives an overview of the cloned expression constructs.

Table 2.9 | Overview of the cloned expression constructs.

\begin{tabular}{|c|c|c|c|c|}
\hline Name & $\begin{array}{l}\text { parental } \\
\text { vector }\end{array}$ & insert & $\begin{array}{l}\text { restriction sites } \\
\left(5^{\prime} / 3^{\prime}\right)\end{array}$ & primer pair \\
\hline pET16b-PR-Set7 & pET16b & PR-Set7 & BamHI/BamHI & $\begin{array}{l}\text { PRSet7-BamHI_for } \\
\text { PRSet7-NotI_rev }\end{array}$ \\
\hline pGEX4T3-PR-Set7 & pGEX4T3 & PR-Set7 & BamHI/NotI & $\begin{array}{l}\text { PRSet7-BamHI_for } \\
\text { PRSet7-NotI_rev }\end{array}$ \\
\hline $\begin{array}{l}\text { pcDNA-HIRA-FIFl- } \\
\text { HAHA }\end{array}$ & $\begin{array}{l}\text { pcDNA } 3.1(+) \\
\text { FlFl HAHA }\end{array}$ & HIRA & NotI/NotI & $\begin{array}{l}\text { HIRA-NotI_for } \\
\text { HIRA-NotI_rev }\end{array}$ \\
\hline
\end{tabular}




\subsubsection{1. pET3a expression constructs for histone proteins}

The pET3a expression vectors containing Xenopus laevis H3 (GenBank: CAD89679), H2A (GenBank: CAD89676), H2B (GenBank: CAD89678) and H4 (GenBank: CAD89677) were a kind gift of Karolin Luger (Colorado State University, Fort Collins, USA) [5].

\subsubsection{Preparation of DNA templates for chromatin assembly}

\subsubsection{Large scale preparation of double-stranded (ds) $\mathrm{DNA}$}

The pBS-G ${ }_{5} \mathrm{ML}$ plasmid was amplified in DH5 $\alpha$ cells by inoculating $2.51 \mathrm{LB}$ medium $(100 \mu \mathrm{g} / \mathrm{ml}$ ampicillin) with $5 \mathrm{ml}$ of an overnight culture. The culture was grown overnight at $37^{\circ} \mathrm{C}$ and cells were harvested by centrifugation for $15 \mathrm{~min}$ at $6,000 \mathrm{xg}$ at $4^{\circ} \mathrm{C}$. The pellet was dissolved in the lysis buffer supplied by the manufacturer and 10-15 mg DNA were purified using the NucleoBond 10000 kit.

To further purify the DNA preparation from nicked material the DNA was subjected to isopycnic cesium chloride $(\mathrm{CsCl})$ density centrifugation [132]. Therefore, the DNA solution was carefully weighed and $1.01 \mathrm{~g} \mathrm{CsCl}$ and $20 \mu \mathrm{l}$ ethidium bromide $(10 \mathrm{mg} / \mathrm{ml})$ were added per gram of DNA solution. The final DNA concentration was about $0.25 \mathrm{mg} / \mathrm{ml}$. The solution was mixed well and filled into $4.4 \mathrm{ml}$ ultracentrifuge tubes. The DNA/CsCl solution was centrifuged for $62 \mathrm{~h}$ in a TH-660 rotor at $49,000 \mathrm{rpm}$ at $20^{\circ} \mathrm{C}$. After the run two ethidium bromide-stained bands were visible. The side of the tube was punctured with a $21 \mathrm{G}$ needle and the lower band was collected.

Ethidium bromide was removed by three extractions with three volumes watersaturated n-butanol. The DNA was diluted with 4 volumes $\mathrm{ddH}_{2} \mathrm{O}$ and precipitated by adding 8 volumes $100 \%$ ethanol and sodium acetate $\mathrm{pH} 5.2$ to $0.1 \mathrm{M}$. The DNA/ethanol mix was incubated for $10 \mathrm{~min}$ on ice followed by centrifugation for $45 \mathrm{~min}$ at $16,000 \mathrm{xg}$ at $4^{\circ} \mathrm{C}$. The pellet was washed twice with $70 \%$ ethanol, air-dried for $5 \mathrm{~min}$ and finally resuspended in $10 \mathrm{mM}$ Tris- $\mathrm{HCl} \mathrm{pH}$ 8.0. The dsDNA concentration (2.2.1.1) was adjusted to $200 \mathrm{ng} / \mu \mathrm{l}$ and dsDNA was stored in small aliquots at $-20^{\circ} \mathrm{C}$. 


\subsubsection{Preparation of M13K07 helper phage stock}

A single E. coli XL1-Blue MRF' colony was picked from an LB/tetracycline agar plate into $2 \mathrm{ml} 2 \mathrm{X} \mathrm{YT/tetracycline} \mathrm{medium}(5 \mu \mathrm{g} / \mathrm{ml}$ tetracycline). The culture was grown for $6-8 \mathrm{~h}$ at $37^{\circ} \mathrm{C}$. M13K07 helper phage was added to a final concentration of $10^{10} \mathrm{pfu} / \mathrm{ml}$ and infected cells were grown for $30 \mathrm{~min}$ at $37^{\circ} \mathrm{C}$. The culture was then diluted 1/500 into fresh 2X YT/kanamycin medium (10 $\mu \mathrm{g} / \mathrm{ml}$ kanamycin) and grown overnight at $37^{\circ} \mathrm{C}$ with vigorous agitation. Phage heads were precipitated by adding $1 / 5$ volume $20 \%[\mathrm{w} / \mathrm{v}] \mathrm{PEG} / 2.5 \mathrm{M} \mathrm{NaCl}$ followed by incubation on ice for $1 \mathrm{~h}$. Phages were resuspended in 1/20 volume $1 \mathrm{X}$ PBS. Phage concentration was estimated photometrically $\left(1 \mathrm{OD}_{268 \mathrm{~nm}}=5 \times 10^{12}\right.$ phage $\left./ \mathrm{ml}\right)$ and adjusted to $10^{13}$ phage $/ \mathrm{ml}$. Glycerol was added to $50 \%[\mathrm{w} / \mathrm{v}]$ for long-term storage at $-80^{\circ} \mathrm{C}$.

\subsubsection{Preparation of single-stranded (ss) DNA using M13K07 helper phage}

The use of phagemid vectors for preparation of ssDNA has been described before $[132,138]$. Here, ssDNA was prepared from frozen DH12S cells according to [139] with modifications.

DH12S cells were transformed by electroshock with $\mathrm{pBS}-\mathrm{G}_{5} \mathrm{ML}$ and plated onto M9 minimal agar plates (1.5\% agar, $1 \mathrm{X}$ M9 salts, $7 \mathrm{mM} \mathrm{MgSO}_{4}, 0.1 \mathrm{mM} \mathrm{CaCl}, 0.8 \%$ glucose, $1 \mathrm{mM}$ thiamine, $75 \mu \mathrm{g} / \mathrm{ml}$ ampicillin) and incubated at $37^{\circ} \mathrm{C}$. Single, small colonies were picked into $2 \mathrm{ml} 2 \mathrm{X}$ YT (supplemented with $100 \mu \mathrm{g} / \mathrm{ml}$ ampicillin, $20 \mathrm{mM}$ glucose, $2 \mathrm{mM} \mathrm{MgSO}$ ) and grown overnight at $37^{\circ} \mathrm{C}$ until stationary phase was reached $\left(\mathrm{OD}_{600 \mathrm{~nm}}=4-6\right)$. Glycerol stocks were prepared by adding $40 \%$ glycerol to the overnight culture. Aliquots were frozen in liquid nitrogen and stored at $-80^{\circ} \mathrm{C}$.

For helper phage-mediated production of ssDNA $500 \mu \mathrm{l}$ of frozen cells were diluted into $50 \mathrm{ml}$ TBG/ampicillin medium $(1.2 \%[\mathrm{w} / \mathrm{v}]$ tryptone, $2.4 \%[\mathrm{w} / \mathrm{v}]$ yeast extract,

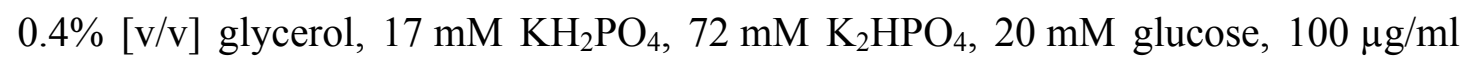
ampicillin). Immediately, $2.5 \mu 1$ of M13K07 helper phage $\left(10^{13}\right.$ phage/ml $)$ was added. After incubation for $2 \mathrm{~h}$ at $37^{\circ} \mathrm{C}$ with vigorous agitation, kanamycin was added to a final concentration of $75 \mu \mathrm{g} / \mathrm{ml}$, and incubation was continued at $37^{\circ} \mathrm{C}$ for $18-24 \mathrm{~h}$ or until cells reached stationary phase.

The cells were pelleted twice for $15 \mathrm{~min}$ at $4,000 \mathrm{rpm}$ at $4{ }^{\circ} \mathrm{C}$ and once for $10 \mathrm{~min}$ at $15,000 \mathrm{xg}, 4^{\circ} \mathrm{C}$. The supernatant was transferred to a new tube after each centrifugation step. For precipitation of phage heads, 1/4 volume 20\% [w/v] PEG 8000/ $2.5 \mathrm{M} \mathrm{NaCl}$ solution was added to the supernatant. The mixture was incubated for 1- 
$2 \mathrm{~h}$ on ice and centrifuged at $30,000 \mathrm{xg}$ for $30 \mathrm{~min}$ at $4^{\circ} \mathrm{C}$.

The pellet was resuspended in $5 \mathrm{ml} 1 \mathrm{X} \mathrm{TE}$ buffer, extracted 3-4 times with phenol:chloroform:isomaylalcohol [25:24:1], once with chloroform:isoamylalcohol [24:1] and finally precipitated by adding 2.5 volumes ethanol and $0.3 \mathrm{M}$ sodium acetate $\mathrm{pH}$ 5.2. The DNA pellet was resuspended in $10 \mathrm{mM}$ Tris- $\mathrm{HCl} \mathrm{pH} 8.0$ and the concentration of ssDNA was determined by UV spectroscopy $\left(1 \mathrm{OD}_{260 \mathrm{~nm}}=33 \mu \mathrm{g} / \mathrm{ml}\right)$. The quality of ssDNA was assessed by digestion with specific nucleases and agarose gel electrophoresis. Therefore, $500 \mathrm{ng}$ of ssDNA was treated either with $2 \mathrm{U}$ DNaseI or $50 \mathrm{U} \mathrm{S} 1$ nuclease in the supplied buffers for $15 \mathrm{~min}$ at $30^{\circ} \mathrm{C}$. Both samples were loaded together with $500 \mathrm{ng}$ untreated ssDNA and $100 \mathrm{ng}$ dsDNA on a $0.8 \%$ agarose gel and the gel was run for $45 \mathrm{~min}$ at $90 \mathrm{~V}$ in $1 \mathrm{X}$ TAE. If helper phage genome was present in the preparation, the band corresponding to the phagemid was cut out and electro-eluted for $60 \mathrm{~min}$ at $90 \mathrm{~V}$ in $1 \mathrm{X}$ TAE. The eluted ssDNA was phenol-extracted twice to remove residual agarose and precipitated again with ethanol/0.3 $\mathrm{M}$ sodium acetate $\mathrm{pH} 5.2$ as described above. The ssDNA concentration was adjusted to $100 \mathrm{ng} / \mu 1$ and the ssDNA was stored in small aliquots at $-20^{\circ} \mathrm{C}$.

\subsubsection{Preparation of mono-/oligonucleosomal DNA templates}

DNA templates suitable for incorporation of one nucleosome were derived from the pUC18_52x187x601 [131] construct, which was a kind gift of Daniela Rhodes (MRC, Cambridge, UK). The template, consisting of 52 repeats of the 601 sequence (187 bp: $147 \mathrm{bp}$ core sequence flanked by $20 \mathrm{bp}$ of linker DNA on each side), was digested with the AvaI isoschizomer BsoBI. The DNA was incubated overnight at $37^{\circ} \mathrm{C}$ with $300 \mathrm{U}$ BsoBI per mg DNA in the appropriate buffer system (supplied by the manufacturer). To separate vector backbone from the $187 \mathrm{bp}$ fragment, $0.5 \mathrm{M} \mathrm{NaCl}$ and $2 \%[\mathrm{w} / \mathrm{v}]$ PEG 6000 were added to the digest. The mixture was centrifuged for $10 \mathrm{~min}$ at $12,000 \mathrm{xg}$ in an HB-6 rotor at $16^{\circ} \mathrm{C}$. The pellet was washed once with $70 \%$ ethanol, air-dried and resuspended in $10 \mathrm{mM}$ Tris- $\mathrm{HCl} \mathrm{pH} \mathrm{8.0.} \mathrm{The} \mathrm{supernatant} \mathrm{was}$ transferred to a new tube. The PEG 6000 concentration was increased by $1 \%$ and centrifugation was repeated as before. After a step-wise increase from 2-9\% PEG 6000 a last precipitation step at 20\% PEG 6000 was performed. All fractions were analyzed by agarose gel electrophoresis (2.2.1.2) and fractions containing only the 187 bp DNA fragment were pooled and used for mononucleosome assembly (2.3.3.2). The pUC18_12x200x601 [9] construct was provided by Daniela Rhodes (MRC, 
Cambridge, UK) as well and used for reconstitution of $12 \mathrm{mer}$ oligonucleosomal chromatin arrays. The vector backbone was digested with DpnI, DdeI, HaeII and EcoRI to liberate the $12 \times 200 x 601$ DNA fragment. $300 \mathrm{U}$ of each enzyme per mg DNA were incubated overnight at $37^{\circ} \mathrm{C}$. The digest mix was precipitated as described above with PEG 6000 concentrations ranging from 5-8\%. Fractions containing only the $12 \times 200 \times 601$ fragment were pooled and used for reconstitution of chromatin arrays.

\subsubsection{Preparation of scavenger DNA}

Scavenger DNA was included as a competitor in reconstitutions of chromatin arrays as described in [9]. The scavenger DNA represents a $147 \mathrm{bp}$ long DNA fragment without positioning sequences and was generated by PCR from the backbone of the pUC18_12x200x601 construct. A PCR mix (100 $\mu$ l) was set up in 1X Taq buffer (100 mM Tris-HCl pH 8.8, $500 \mathrm{mM} \mathrm{KCl,} \mathrm{0.8 \%} \mathrm{[v/v]} \mathrm{NP-40)} \mathrm{with} 0.2 \mathrm{mM}$ dNTPs, $0.2 \mu \mathrm{M}$ scavenger forward primer, $0.2 \mu \mathrm{M}$ scavenger reverse primer, $1.5 \mathrm{mM} \mathrm{MgCl}_{2}$, 50 ng DNA template and $20 \mathrm{U} / \mathrm{ml}$ Taq polymerase (purified by Winfried Lendeckel) For large scale preparations two 96-well PCR plates were incubated in a thermocycler according to the following program:

$\begin{array}{ll}\text { temperature } & \text { time } \\ 95^{\circ} \mathrm{C} & 2 \mathrm{~min} \\ 95^{\circ} \mathrm{C} & 30 \mathrm{~s} \\ 68^{\circ} \mathrm{C} & 30 \mathrm{~s} \\ 72^{\circ} \mathrm{C} & 30 \mathrm{~s} \\ 72^{\circ} \mathrm{C} & 1 \mathrm{~min} \\ 10^{\circ} \mathrm{C} & \infty\end{array}$

The PCR product was extracted with phenol:chloroform:isoamylalcohol [25:24:1] and precipitated with ethanol/0.3 M sodium acetate $\mathrm{pH}$ 5.2. 


\subsection{Protein biochemistry methods}

\subsubsection{Detection and analysis of proteins}

\subsubsection{Concentration determination of proteins}

The concentration of proteins was determined by UV spectroscopy at $280 \mathrm{~nm}$ using the theoretical molar extinction coefficient and molecular weight as calculated from the amino acid sequence by ProtParam ([140]; http://expasy.org/tools/). Histone proteins were measured at $276 \mathrm{~nm}$ according to published molar extinction coefficients [135]. Table 2.10 lists the theoretical molar extinction coefficient and the molecular weight of the proteins used in this study. In some cases protein concentration was determined by a Bradford assay according to the manufacturer's protocol against a BSA standard.

Table 2.10 | Molecular weights and extinction coefficients of proteins at given wavelength.

\begin{tabular}{lccc}
\hline Protein & $\begin{array}{c}\text { Molecular } \\
\text { weight [Da] }\end{array}$ & wavelength & $\begin{array}{c}\text { molar extinction } \\
\text { coefficient }\left[\mathbf{M}^{-1} \mathbf{c m}^{-1}\right]\end{array}$ \\
\hline \hline H3 & 15,273 & $276 \mathrm{~nm}$ & 4,040 \\
H2A & 13,960 & $276 \mathrm{~nm}$ & 4,050 \\
H2B & 13,774 & $276 \mathrm{~nm}$ & 6,070 \\
H4 & 11,236 & $276 \mathrm{~nm}$ & 5,400 \\
H3.3 & 15,197 & $276 \mathrm{~nm}$ & 4,470 \\
H3 A21C $41-20$ & 13,137 & $276 \mathrm{~nm}$ & 4,040 \\
His-H3.3 & 17,662 & $276 \mathrm{~nm}$ & 5,960 \\
His-PR-Set7 & 41,263 & $280 \mathrm{~nm}$ & 26,735 \\
GST-PR-Set7 & 64,685 & $280 \mathrm{~nm}$ & 68,355 \\
GST & 27,795 & $280 \mathrm{~nm}$ & 43,110 \\
\hline
\end{tabular}

\subsubsection{Denaturing polyacrylamide gel electrophoresis of proteins (SDS-PAGE)}

Proteins were separated based on the discontinuous polyacrylamide gel electrophoresis in presence of SDS [141] according to standard protocols [142]. Generally, Tris-glycine gels with a $12-15 \%$ resolving gel $(12-15 \%$ [w/v] acrylamide:bisacrylamide (37.5:1), 0.4 M Tris- $\mathrm{HCl} \mathrm{pH} 8.8,0.1 \%$ [w/v] SDS, 0.1\% $[\mathrm{w} / \mathrm{v}]$ APS, $0.04 \% \quad[\mathrm{v} / \mathrm{v}] \quad$ TEMED $)$ and a $4 \%$ stacking gel $(4 \%$ acrylamide:bisacrylamide (37.5:1), $0.68 \mathrm{M}$ Tris- $\mathrm{HCl} \mathrm{pH} 6.8,0.1 \%$ [w/v] SDS, $0.1 \%$ [w/v] APS, 0.1\% [v/v] TEMED) were used. The Mini-PROTEAN 3 system was used 
to pour and run the gels. Protein samples were boiled in SDS sample buffer for $5 \mathrm{~min}$ at $95^{\circ} \mathrm{C}$ before loading. As size reference, $5 \mu 1$ SeeBlue Plus2 Pre-stained protein standard was loaded on the gel. Samples were run on the gels at constant current at 25-30 mA (250 V maximum) in 1X SDS running buffer until the bromophenol blue had reached the bottom of the gel.

For mass spectrometric analysis of protein samples the NuPAGE Pre-cast system was used according to manufacturer's instructions.

\subsubsection{Coomassie staining of protein gels}

SDS-PAGE gels were stained with Coomassie staining solution for 15-30 min at RT and destained with Destaining solution for $60 \mathrm{~min}$ at RT.

\subsubsection{Western blot analysis}

The MiniTrans Blot system was used for immunoblotting of protein samples separated by SDS-PAGE. The gel was sandwiched between a stack of fiber padWhatman paper-nitrocellulose membrane, equilibrated in transfer buffer (1X SDS running buffer, $20 \%[\mathrm{v} / \mathrm{v}]$ methanol), as described in the manufacturer's protocol. Proteins were blotted onto the nitrocellulose membrane in transfer buffer for $1 \mathrm{~h}$ at $100 \mathrm{~V}$ at $4^{\circ} \mathrm{C}$. The membrane was washed once with $\mathrm{ddH}_{2} \mathrm{O}$ and stained with Ponceau $\mathrm{S}$ solution $(5 \%[\mathrm{v} / \mathrm{v}]$ acetic acid, $0.1 \%[\mathrm{w} / \mathrm{v}]$ Ponceau S) for $5 \mathrm{~min}$ at RT. The membrane was rinsed with PBS-T (1X PBS, 0.1\% [v/v] Tween20) and further blocked in PBS-T/5\% milk (PBS-T, 5\% [w/v] milk powder) for $1 \mathrm{~h}$ at RT. For immunodetection the primary antibody solution (Table 2.5) in PBS-T/2.5\% milk was added and incubated for $1 \mathrm{~h}$ at RT or overnight at $4^{\circ} \mathrm{C}$. After three washes with PBS-T for $10 \mathrm{~min}$ at RT, the membrane was incubated with the secondary antibody solution (in PBS-T/2.5\% milk) for $1 \mathrm{~h}$ at RT. The membrane was washed three times for 10 min in PBS-T and the blot was developed using an enhanced chemiluminescence system (ECL or ECL Plus).

For reprobing of blots with a different primary antibody [143], the nitrocellulose membrane was incubated with $60^{\circ} \mathrm{C}$-warm Stripping buffer $(62.5 \mathrm{mM}$ Tris-HCl $\mathrm{pH} 6.8,2 \%[\mathrm{w} / \mathrm{v}] \mathrm{SDS}, 100 \mathrm{mM}$ 2-mercaptoethanol) for $30 \mathrm{~min}$ at $55^{\circ} \mathrm{C}$ in a hybridization oven. The membrane was washed several times in $\mathrm{ddH}_{2} \mathrm{O}$, PBS-T and blocked in PBS-T/5\% milk before reprobing. 


\subsubsection{Recombinant proteins}

E. coli BL21 (DE3) CodonPlus RIL were transformed with the expression construct of interest and single colonies were picked from LB agar plates containing the appropriate antibiotics for selection in $5 \mathrm{ml} \mathrm{LB} \mathrm{(+} \mathrm{antibiotics).} \mathrm{This} \mathrm{starter} \mathrm{culture} \mathrm{was}$ grown overnight at $37^{\circ} \mathrm{C}$ and used for inoculation of $2 \mathrm{X}$ YT medium (plus antibiotics). Cultivation was continued at $37^{\circ} \mathrm{C}$ until $\mathrm{OD}_{600 \mathrm{~nm}}$ reached $0.4-0.6$. At this point protein expression was induced with $0.6 \mathrm{mM}$ IPTG and cells were incubated for $3-4 \mathrm{~h}$ at $37^{\circ} \mathrm{C}$ (histone proteins) or overnight at $20^{\circ} \mathrm{C}$ (non-histone proteins) while shaking at $140 \mathrm{rpm}$. Induction of protein expression was monitored by SDS-PAGE (2.3.1.2) and cells were harvested by centrifugation for $15 \mathrm{~min}$ at $6,000 \mathrm{xg}$ at $4{ }^{\circ} \mathrm{C}$.

\subsubsection{Purification of His-PR-Set7}

Cells expressing His-PR-Set7 were pelleted and resuspended in $10 \mathrm{ml}$ lysis buffer (50 mM NaP $\mathrm{pH}_{\mathrm{i}}$.8, $300 \mathrm{mM} \mathrm{NaCl}, 10 \mathrm{mM}$ imidazole, $2 \mathrm{mM}$ PMSF, $2 \mathrm{mM}$ benzamidine, $10 \mathrm{mM}$ 2-mercaptoethanol) per liter of culture. The solution was flashfrozen in liquid nitrogen and stored at $-80^{\circ} \mathrm{C}$. For purification the solution was thawed at $37^{\circ} \mathrm{C}$ for $15-20 \mathrm{~min}$. Cell lysis was achieved by 3-4 passages through an EmulsiFlex-C5 homogenizer at $>10,000$ psi. The lysate was supplemented with $0.25 \%[\mathrm{v} / \mathrm{v}]$ Triton X-100 and complete protease inhibitor cocktail (EDTA-free) and rotated for $30-60 \mathrm{~min}$ at $4^{\circ} \mathrm{C}$. After centrifugation at $35,000 \mathrm{xg}$ for $30 \mathrm{~min}$ at $4^{\circ} \mathrm{C}$ the supernatant was added to TALON beads ( $2 \mathrm{ml}$ slurry/liter culture), equilibrated with lysis buffer, and incubated in a glass column for 1 hour at $4{ }^{\circ} \mathrm{C}$ while rotating. The column was drained and washed with WB 500 (lysis buffer with $500 \mathrm{mM} \mathrm{NaCl}$ ) to remove unbound protein and eluted with Elution buffer $\left(50 \mathrm{mM} \mathrm{NaP} \mathrm{P}_{\mathrm{i}} \mathrm{pH} 6.8\right.$, $300 \mathrm{mM} \mathrm{NaCl}, 500 \mathrm{mM}$ imidazole, $10 \mathrm{mM}$ 2-mercaptoethanol).

For activity assays eluted protein was diluted 1:4 with dialysis buffer $(25 \mathrm{mM} \mathrm{NaP}$ pH 7, $100 \mathrm{mM} \mathrm{NaCl}, 0.1 \mathrm{mM}$ EDTA, $10 \mathrm{mM}$ 2-mercaptoethanol), supplemented with $10 \%[\mathrm{v} / \mathrm{v}]$ glycerol, flash-frozen in liquid nitrogen and stored at $-80^{\circ} \mathrm{C}$.

\subsubsection{Purification of GST-fusion proteins}

E. coli BL21 (DE3) CodonPlus RIL expressing GST or GST-PR-Set7 were harvested by centrifugation, the pellet was drained and resuspended in $5 \mathrm{ml} 1 \mathrm{X}$ PBS (supplemented with $2 \mathrm{mM}$ DTT, $2 \mathrm{mM}$ benzamidine, $2 \mathrm{mM}$ PMSF) per liter of culture. 
The cells were lysed with an EmulsiFlex-C5 cell homogenizer and the lysate was supplemented with $0.25 \%$ [v/v] Triton X-100 and complete protease inhibitor cocktail and rotated for $30-60 \mathrm{~min}$ at $4{ }^{\circ} \mathrm{C}$. After centrifugation at $35,000 \mathrm{x}$ g for $30 \mathrm{~min}$ at $4{ }^{\circ} \mathrm{C}$ the supernatant was added to PBS-washed glutathione sepharose slurry $(1.5 \mathrm{ml} / \mathrm{liter}$ culture) and rotated in a glass column for 1 hour at $4^{\circ} \mathrm{C}$. The column was drained and the beads were washed first PBS/150 mM NaCl and then with PBS/500 $\mathrm{mM} \mathrm{NaCl}$. GST proteins were eluted from beads with GST Elution buffer $(50 \mathrm{mM}$ Tris- $\mathrm{HCl}$ $\mathrm{pH} 9.5,150 \mathrm{mM} \mathrm{NaCl}, 10 \mathrm{mM}$ reduced glutathione) and fractions of $5 \mathrm{ml}$ size were collected. $10 \mu \mathrm{l}$ of each fraction was analyzed by SDS-PAGE, peak fractions pooled and the concentration was determined by a Bradford assay. The protein was stored at $-20^{\circ} \mathrm{C}$ with $20 \%$ [v/v] glycerol.

\subsubsection{Purification of recombinant histone proteins}

Purification of recombinant Xenopus laevis histones from inclusion bodies was performed as described in [135] with some modifications. In brief, cell pellets were resuspended in Wash buffer $(50 \mathrm{mM}$ Tris- $\mathrm{HCl} \mathrm{pH}$ 7.5, $100 \mathrm{mM} \mathrm{NaCl}, 1 \mathrm{mM}$ EDTA, $1 \mathrm{mM}$ PMSF, $2 \mathrm{mM}$ DTT) and cells were lysed with an EmulsiFlex-C5 homogenizer at $>10,000$ psi. The cell lysate was cleared by centrifugation for $20 \mathrm{~min}$ at $23,000 \mathrm{x} \mathrm{g}$, $4^{\circ} \mathrm{C}$, in an SS-34 rotor. The pellet was resuspended in TW buffer (Wash buffer, $1 \%$ [v/v] Triton X-100) and centrifuged for $10 \mathrm{~min}$ at $23,000 \mathrm{xg}, 4^{\circ} \mathrm{C}$. This step was repeated twice with TW buffer and twice with Wash buffer. The inclusion body pellet was soaked in 1-2 pellet volumes DMSO, minced and incubated for $30 \mathrm{~min}$ at RT. Proteins were extracted by adding 30-40 volumes Unfolding buffer (7 M guanidinium- $\mathrm{HCl}, 20 \mathrm{mM}$ Tris- $\mathrm{HCl} \mathrm{pH}$ 7.5, $10 \mathrm{mM}$ DTT) and the mixture was gently stirred for $1 \mathrm{~h}$ at RT.

After centrifugation for $10 \mathrm{~min}$ at $23,000 \mathrm{xg}$ at $4^{\circ} \mathrm{C}$ the supernatant was immediately loaded onto a Sephacryl S200 XK50/100 column equilibrated with SAU-1000 (7 M freshly deionized urea, $20 \mathrm{mM}$ sodium acetate $\mathrm{pH} 5.2,1 \mathrm{mM}$ EDTA, $1 \mathrm{M} \mathrm{NaCl}$, $1 \mathrm{mM}$ DTT). The column was developed in SAU-1000 and peak fractions were collected and analyzed by SDS-PAGE (2.3.1.2).

The fractions containing histone protein were pooled and ion exchange chromatography was employed as a second purification step. The protein was diluted with 5 volumes SAU-0 (SAU-1000 but $0 \mathrm{M} \mathrm{NaCl}$ ) and loaded onto a XK26/20 QSepharose column connected in series to a XK26/20 SP-Sepharose column. Both 
columns had been equilibrated with SAU-200. When loading was complete, the QSepharose column was detached and the histone protein was eluted from the SPcolumn with a linear gradient from 200-600 $\mathrm{mM} \mathrm{NaCl}$.

The peak fractions were analyzed by SDS-PAGE and the histone protein was dialyzed excessively against $\mathrm{ddH}_{2} \mathrm{O} / 2 \mathrm{mM}$ DTT, lyophilized and stored at $-80^{\circ} \mathrm{C}$

\subsubsection{Purification of His-tagged H3.3}

The pRUTH-H3.3 plasmid was a kind gift of Simon Elsässer (C. D. Allis laboratory, Rockefeller University). Human histone H3.3 was expressed with a N-terminal His6tag followed by a TEV protease cleavage site for tag removal. Cells grown in $212 \mathrm{X}$ YT medium (kanamycin/chloramphenicol) were harvested by centrifugation, resuspended in $10 \mathrm{ml}$ of WL buffer $(50 \mathrm{mM}$ Tris- $\mathrm{HCl} \mathrm{pH} 8.0,100 \mathrm{mM} \mathrm{NaCl}, 5 \mathrm{mM}$ imidazolee, $10 \mathrm{mM}$ 2-mercaptoethanol, $1 \mathrm{mM}$ PMSF) and flash-frozen in liquid nitrogen.

Cell pellets were thawed and exhaustively lysed in $20 \mathrm{ml}$ WL buffer by four passages through a cell homogenizer at $>10,000$ psi. The lysate was clarified by centrifugation at $20,000 \mathrm{xg}$ for $15 \mathrm{~min}$ at $4{ }^{\circ} \mathrm{C}$. The supernatant was decanted and histone $\mathrm{H} 3.3$ was purified from inclusion bodies under denaturing conditions. Therefore, inclusion bodies were washed with $5 \mathrm{ml}$ WL buffer, resuspended via vortexing with 1-2 ml glass beads ( $5 \mathrm{~mm}$ diameter) and brief bath sonication. $15 \mathrm{ml} \mathrm{WL}$ buffer and $20 \mathrm{ml}$ WLT (WL plus $1 \%$ [v/v] Triton X-100) buffer was added, vigorously vortexed and centrifuged with the beads kept in the tubes at 13,000 x g for $10 \mathrm{~min}$. The pellet was first rinsed with $10 \mathrm{ml}$ WL buffer, then resuspended in $5 \mathrm{ml}$ WL buffer before addition of $35 \mathrm{ml}$ more WL buffer to cleanse inclusion bodies of detergent. The centrifugation step was repeated and glass beads were removed.

At RT the inclusion bodies were soaked in $1 \mathrm{ml}$ DMSO for $30 \mathrm{~min}$, bath sonicated and carefully resuspended. $35 \mathrm{ml} \mathrm{D500} \mathrm{(6.3} \mathrm{M} \mathrm{guanidine-} \mathrm{HCl}, 50 \mathrm{mM}$ Tris $\mathrm{pH} 8.0$, $500 \mathrm{mM} \mathrm{NaCl}, 10 \mathrm{mM}$ 2-mercaptoethanol) was added slowly and the suspension was rotated for 1 hour at RT to extract $\mathrm{His}_{6}-\mathrm{H} 3.3$. After centrifugation at 30,000 x $\mathrm{g}$ for $20 \mathrm{~min}$ at $4^{\circ} \mathrm{C}$, the supernatant was incubated in a glass column with $2 \mathrm{ml} \mathrm{Ni-NTA-}$ agarose slurry (equilibrated in D500) for $1-2$ hours at $4^{\circ} \mathrm{C}$ while rotating. The column was drained and beads were washed stepwise with $30 \mathrm{ml} \mathrm{D500}$ and $40 \mathrm{ml} \mathrm{D1000.}$ Bound protein was eluted with $\mathrm{D} 1000+300 \mathrm{mM}$ imidazole in three $5 \mathrm{ml}$ fractions. Histones were desalted by quick passage over a PD10 column equilibrated with Dead 
fish buffer (100 mM trimethylamine acetate $\mathrm{pH} 5,5 \mathrm{mM}$ 2-mercaptoethanol). The protein was eluted with $3.5 \mathrm{ml}$ Dead fish buffer, immediately flash-frozen and lyophilized. The lyophilized material was resuspended in $\mathrm{ddH}_{2} \mathrm{O}$ and concentration was determined by measuring $\mathrm{OD}_{280}\left(\mathrm{MW} 17.662 \mathrm{Da}, \varepsilon=5960 \mathrm{M}^{-1} \mathrm{~cm}^{-1}\right.$ ).

The His 6 tag was removed by adding 1/100 mass equivalents TEV protease to the protein in TEV buffer (50 mM Tris- $\mathrm{HCl}$ pH 7.5, $50 \mathrm{mM} \mathrm{NaCl}, 1 \mathrm{mM}$ DTT). After incubation for $12-16 \mathrm{~h}$ at $16^{\circ} \mathrm{C}$ about $95 \%$ of protein was digested. Uncut $\mathrm{His}_{6}-\mathrm{H} 3.3$ and TEV protease were removed by two passages of the digestion mix over $\mathrm{Ni}^{2+}$-NTA agarose packed in a glass column. The $\mathrm{H} 3.3$ was dialyzed against $\mathrm{ddH}_{2} \mathrm{O} / 2 \mathrm{mM}$ DTT, lyophilized and stored at $-80^{\circ} \mathrm{C}$.

\subsubsection{Generation of $\mathrm{H} 3 \mathrm{~K} 4 \mathrm{me} 3$ histones by native protein ligation}

Histone H3 trimethylated on lysine 4 ( $\mathrm{H} 3 \mathrm{~K} 4 \mathrm{me} 3)$ were generated by native protein ligation essentially as described elsewhere [144]. The ligation was performed by Szabolcs Sörös (Chromatin Biochemistry, Max Planck Institute for Biophysical Chemistry) using an N-terminally truncated histone H3 (H3 A21C $\Delta 1-20)$ and a 20 amino acid-long peptide containing the modification and a C-terminal thioester (peptide synthesized by Peter Henklein, Charité, Berlin).

H3K4me3 (aa 1-20) peptide sequence:

$\mathrm{NH}_{2}-\mathrm{ARTK}_{\text {me3 }} \mathrm{QTARKSTGGKAPRKQL} \mathrm{-} \mathrm{(thioester)}$

\subsubsection{Expression of HIRA in rabbit reticulocyte lysate}

FLAG-tagged HIRA was expressed using the TNT Quick Coupled Transcription/ Translation System according to the manufacturer's instruction. A reaction mix contained $20 \mu \mathrm{l}$ TNT Quick master mix, $0.5 \mu 11 \mathrm{mM}$ methionine, $0.5 \mu \mathrm{g}$ plasmid DNA (pcDNA 3.1-HIRA-HAHA-FlFl) and $\mathrm{ddH}_{2} \mathrm{O}$ in a final volume of $50 \mu 1$. The reaction was incubated for $90 \mathrm{~min}$ at $30^{\circ} \mathrm{C}$.

\subsubsection{GST-pulldown assays}

Protein-protein interaction was investigated by GST-pulldown assay. $5 \mu$ g protein was bound to $5 \mu \mathrm{l}$ magnetic glutathione beads overnight at $4^{\circ} \mathrm{C}$ in PD150 $(20 \mathrm{mM}$

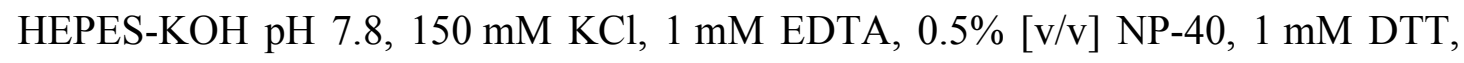
complete protease inhibitor cocktail). Beads were kept in suspension by rotating. The beads were washed three times with PD150 and $25 \mu 1$ of in vitro translated HIRA (2.3.2.6) was added. The volume was adjusted to $1 \mathrm{ml}$ using PD150 and the beads 
were rotated for $2 \mathrm{~h}$ at $4^{\circ} \mathrm{C}$. The beads were washed 6 times for 5 min with PD150. Bound protein was eluted off the beads by adding 2X SDS sample buffer. Beads were boiled for $5 \mathrm{~min}$ at $95^{\circ} \mathrm{C}$ and separated by SDS-PAGE.

\subsubsection{Immunoprecipiation of $x$ HIRA from high-speed egg extracts}

To immunoprecipitate xHIRA $5 \mu$ polyclonal anti-xHIRA (gift of Genevieve Almouzni, Institute Curie, Paris [97]) or $5 \mu 1$ preimmune serum were added to $100 \mu 1$ HSE and incubated overnight at $4^{\circ} \mathrm{C}$ rotating at $300 \mathrm{rpm}$ in a thermomixer. The HSEantibody mixture was transferred to $40 \mu \mathrm{l}$ magnetic sheep anti-rabbit beads (Dynabeads), which had been washed three times with PD150. The bead suspension was rotated for $4 \mathrm{~h}$ at $4^{\circ} \mathrm{C}$ to allow antibody binding to the beads, followed by 6 washes with PD-150. The beads were used for HMT assays (2.3.2.9) or proteins were eluted from beads by boiling them for $5 \mathrm{~min}$ at $95^{\circ} \mathrm{C}$ in $2 \mathrm{X}$ SDS sample buffer. Eluted proteins were further analyzed by SDS-PAGE followed either by Western blot (2.3.1.4) or mass spectrometry analyses of Coomassie-stained gels.

\subsubsection{Histone methyltransferase (HMT) assay}

Recombinant PR-Set7 was tested for histone methyltransferase activity by incubating 0.01-1 $\mu \mathrm{g}$ His-PR-Set7 with $2 \mu \mathrm{g}$ of either histone proteins or mononucleosomes and $2 \mu 1{ }^{3} \mathrm{H}-\mathrm{SAM}(10 \mathrm{Ci} / \mathrm{mmol})$ in $1 \mathrm{X}$ HMT buffer $(50 \mathrm{mM}$ Tris-HCl $\mathrm{pH} 8.8,5 \mathrm{mM}$ $\mathrm{MgCl}_{2}, 4 \mathrm{mM}$ DTT) in a total volume of $20 \mu \mathrm{l}$. The reaction was run for $60 \mathrm{~min}$ at $30^{\circ} \mathrm{C}$ and stopped by addition of SDS sample buffer.

Washed affinity beads with immunoprecipitated HIRA (2.3.2.8) were incubated under the same conditions for $90 \mathrm{~min}$ at $30^{\circ} \mathrm{C}$ at $1200 \mathrm{rpm}$ to keep beads in suspension.

The reaction mix was loaded on a SDS-gel and analyzed by autoradiography (2.4.7.3).

\subsubsection{Recombinant chromatin}

\subsubsection{Assembly of octamers and tetramers}

Lyophilized histone core proteins (H3, H4, H2A, H2B) were dissolved in Unfolding buffer (7 M guanidinium-HCl, 20 mM Tris-HCl pH 7.5, 10 mM DTT) and incubated on ice for $30 \mathrm{~min}$ as described in [135]. The histone proteins were mixed in equimolar rations and total protein concentration was adjusted to $1 \mathrm{mg} / \mathrm{ml}$ with Unfolding buffer. For refolding and assembly of octamer complexes the histone mix was dialyzed at $4^{\circ} \mathrm{C}$ against three changes of $\mathrm{RB}$ high $(10 \mathrm{mM}$ Tris- $\mathrm{HCl} \mathrm{pH} 7.5,2 \mathrm{M} \mathrm{NaCl}, 1 \mathrm{mM}$ 
EDTA, 1 mM DTT).

The formed octamers were concentrated to $10-15 \mathrm{mg} / \mathrm{ml}$ and loaded onto a HiLoad 16/60 Superdex 200 prep grade gelfiltration column equilibrated with RB high. Octamers were purified from dimers and free histones on an ÄKTA FPLC system. The octamer peak fractions were pooled and concentrated to $2-10 \mathrm{mg} / \mathrm{ml}$. For longterm storage at $-20^{\circ} \mathrm{C} 50 \%[\mathrm{v} / \mathrm{v}]$ glycerol was added.

For tetramer assembly only histones $\mathrm{His}_{6}-\mathrm{H} 3.3$ and $\mathrm{H} 4$ were used and treated as described above.

\subsubsection{Chromatin reconstitution by salt dialysis}

Reconstitution of mononucleosomes and chromatin arrays was achieved by dialysis from high to low salt concentrations as described in $[9,135]$.

Octamers (in RB high $/ 50 \%$ glycerol) were dialyzed for $5 \mathrm{~h}$ against $\mathrm{RB}$ high and concentration was determined photometrically $\left(0.45 \mathrm{OD}_{276 \mathrm{~nm}}=1 \mathrm{mg} / \mathrm{ml}\right.$ octamer $=$ $92.2 \mu \mathrm{M})$. Octamers and DNA template (2.2.5.4) were mixed at a molar ratio [octamer/DNA] of 0.9 (mononucleosomes) or 1.1 (chromatin arrays) at $2 \mathrm{M} \mathrm{NaCl}$. An equimolar amount of scavenger DNA (2.2.5.5) was added to assemblies containing the array template. The salt concentration was lowered to $\sim 25 \mathrm{mM} \mathrm{NaCl}$ by dialysis against RB low (10 mM Tris-HCl pH 7.5, 10 mM NaCl, 1 mM EDTA, 1 mM DTT) at $4^{\circ} \mathrm{C}$. Dialysis was performed by continuously replacing RB high over $36 \mathrm{~h}$ with RB low using a peristaltic pump as described [135]. Mononucleosomes were analyzed by native PAGE (2.2.1.3) and chromatin arrays by agarose gel electrophoresis on a $0.5 \%[\mathrm{w} / \mathrm{v}]$ gel in $0.2 \mathrm{X}$ TB $(18 \mathrm{mM}$ Tris-base, $18 \mathrm{mM}$ boric acid $)$ at $4^{\circ} \mathrm{C}$. Mononucleosomes and chromatin arrays were stored at $4^{\circ} \mathrm{C}$ for up to 6 months.

\subsection{Xenopus-based methods}

\subsubsection{Preparation of frog egg extracts}

Various types of egg and oocyte extracts have been described in the literature [86-88, 145]. Here, a high-speed egg extract was prepared according to [146] with modifications.

Female Xenopus laevis were primed with 800-1000 U of human chorionic gonadotropin (HCG) and frogs were kept at $16^{\circ} \mathrm{C}$. Freshly laid eggs were collected 
$\sim 12 \mathrm{~h}$ after injection with HCG and washed with $0.5 \mathrm{X}$ MMR in a beaker at RT. After decanting as much as possible of the MMR, 3-5 volumes $2 \%[\mathrm{w} / \mathrm{v}]$ cysteine $\mathrm{pH} 7.8$ were added and eggs were dejellied by gently swirling them every $30 \mathrm{~s}$. Typically, dejellying was completed after 5-8 min with eggs forming a highly compact layer when settled. The cysteine solution was decanted and the eggs were washed three times with 0.5X MMR. At each wash step debris and malformed or lysed eggs were removed with a wide-bore Pasteur pipet. Eggs were inspected under a dissecting microscope. Inspected batches were pooled and washed three times with ELB (1X ELB salts, $250 \mathrm{mM}$ sucrose, $1 \mathrm{mM}$ DTT, $50 \mu \mathrm{g} / \mathrm{ml}$ cycloheximide).

The washed eggs were transferred to a $12 \mathrm{ml}$ tube filled with $5 \mathrm{ml} \mathrm{ELB}, 2.5 \mu 1$ 1000X LPC (10 mg/ml leupeptin/pepstatin/chymostatin in DMSO) and $2.5 \mu 1$ cytochalasin B $(5 \mathrm{mg} / \mathrm{ml}$ in DMSO). After the eggs had settled, they were subjected to centrifugation for $30 \mathrm{~s}$ at $200 \mathrm{xg}$ and $20 \mathrm{~s}$ at $500 \mathrm{xg}$ to further pack them. The supernatant was aspirated and eggs were overlaid with $0.5 \mu 1$ 1000X LPC and $0.5 \mu 1$ cytochalasin B per milliliter of packed eggs. The tubes were transferred to a Sorvall HB-6 rotor, warmed to RT, and eggs were crushed by centrifugation for $20 \mathrm{~min}$ at $20,000 \mathrm{x} \mathrm{g}$ at $4^{\circ} \mathrm{C}$ in a precooled centrifuge. From this point on, egg extracts were always kept on ice. Each tube was punctured with a $21 \mathrm{G}$ needle right above the dark mitochondrial layer. The needle was removed and a fresh needle attached to a $10 \mathrm{ml}$ syringe was inserted. The straw-colored cytoplasmatic low-speed extract (LSE) was withdrawn and supplemented with $5 \mu \mathrm{l}$ cycloheximide $(10 \mathrm{mg} / \mathrm{ml}), 1 \mu \mathrm{l} 1000 \mathrm{X}$ LPC, $1 \mu \mathrm{l}$ cytochalasin B and $1 \mu$ DTT $(1 \mathrm{M})$ per milliliter of LSE.

The LSE was immediately transferred to $2.2 \mathrm{ml}$ thin-wall ultracentrifuge tubes and centrifuged for $90 \mathrm{~min}$ at 55,000 rpm $[\sim 260,000 \mathrm{x} \mathrm{g}]$ in a Sorvall S55-S rotor at $4^{\circ} \mathrm{C}$. The top lipid layer was aspirated with a gel-loading tip and the clarified high-speed egg extract (HSE) was collected with a cut-off P1000 pipet tip. The HSE was recentrifuged for another $30 \mathrm{~min}$ to remove residual membranes and debris. The extract was frozen in liquid nitrogen as one-use aliquots $(50 \mu \mathrm{l})$ and stored at $-80^{\circ} \mathrm{C}$. The protein concentration of a typical HSE preparation ranged between $30-40 \mathrm{mg} / \mathrm{ml}$ as determined by a Bradford assay (2.3.1.1). 


\subsubsection{Standard chromatin assembly in HSE}

\subsubsection{Using circular DNA templates}

A $25-\mu 1$ standard chromatin assembly mix contained either $200 \mathrm{ng}$ dsDNA or $100 \mathrm{ng}$ ssDNA in $40 \mathrm{mM}$ HEPES-KOH pH 7.8, $40 \mathrm{mM}$ phosphocreatine, $5 \mathrm{mM} \mathrm{MgCl}_{2}$, $0.5 \mathrm{mM}$ DTT, $4 \mathrm{mM}$ ATP, $2.5 \mu \mathrm{g}$ creatine kinase and $10 \mu \mathrm{l}$ HSE. Therefore, the following reagents were mixed on ice in the given order: $5 \mu 15 \mathrm{X}$ reaction mix, $1 \mu 1$ $100 \mathrm{mM}$ ATP (Sigma), $1 \mu 12.5 \mathrm{mg} / \mathrm{ml}$ creatine kinase and $10 \mu \mathrm{HSE}$. The final volume was adjusted to $25 \mu \mathrm{l}$ with $\mathrm{ddH}_{2} \mathrm{O}$ and DNA was added to start the chromatin assembly. The reaction mix was incubated for $4 \mathrm{~h}$ at $23^{\circ} \mathrm{C}$ in a thermomixer. The chromatin was analyzed either by precipitation with $\mathrm{MnCl}_{2}, \mathrm{MNase}$ digestion, a supercoiling assay or sucrose density gradient centrifugation.

\subsubsection{Using demembranated sperm chromatin}

Demembranated Xenopus laevis sperm chromatin was a kind gift of Bastian Hülsmann (Görlich laboratory, Max Planck Institute for biophysical chemistry, Göttingen). The sperm chromatin was prepared by a protocol based on [147] and diluted to 30,000 nuclei/ $\mu 1$. To a standard assembly reaction 1500 nuclei/ $\mu 1 \mathrm{HSE}$ were added and incubated for $2 \mathrm{~h}$ at $23^{\circ} \mathrm{C}$.

The sperm chromatin was recovered by centrifugation for $15 \mathrm{~min}$ at $16,000 \mathrm{xg}$ at $4^{\circ} \mathrm{C}$. The pellet was washed twice with CP 0 (20 mM HEPES-KOH pH 7.8, $150 \mathrm{mM}$ $\mathrm{KCl}, 0.1 \mathrm{mM}$ EDTA, $0.1 \%$ [v/v] Triton $\mathrm{X}-100$ ) for $15 \mathrm{~min}$ at $16,000 \mathrm{xg}$ at $4^{\circ} \mathrm{C}$. The pellet was dissolved in $2 \mathrm{X}$ SDS sample buffer.

\subsubsection{Precipitation of $\mathrm{HSE}$-derived chromatin with $\mathrm{MnCl}_{2}$}

For precipitation of chromatin a standard assembly was scaled up 5-fold ( $1 \mu \mathrm{g}$ dsDNA or $0.5 \mu \mathrm{g}$ ssDNA). Following incubation for $4 \mathrm{~h}$ at $23^{\circ} \mathrm{C}$ the reaction was centrifuged for $10 \mathrm{~min}$ at $16,000 \mathrm{xg}$ at $4^{\circ} \mathrm{C}$. The pellet of this centrifugation step was washed twice with $200 \mu \mathrm{CPO}(20 \mathrm{mM}$ HEPES-KOH pH 7.8, $150 \mathrm{mM} \mathrm{KCl}, 0.1 \mathrm{mM}$ EDTA, $0.1 \%[\mathrm{v} / \mathrm{v}]$ Triton $\mathrm{X}-100$ ) for $15 \mathrm{~min}$ at $16,000 \mathrm{xg}$ at $4^{\circ} \mathrm{C}$. The supernatant was transferred to a new tube and $\mathrm{MnCl}_{2}$ was added to a final concentration of $8 \mathrm{mM}$. After incubation for $30 \mathrm{~min}$ on ice the chromatin was pelleted by centrifugation for $30 \mathrm{~min}$ at $16,000 \mathrm{xg}$ at $4^{\circ} \mathrm{C}$. The pellet was washed twice with $200 \mu \mathrm{CP} 8$ (CP 0 with $8 \mathrm{mM} \mathrm{MnCl}_{2}$ ) for $15 \mathrm{~min}$ at $16,000 \mathrm{xg}$ at $4^{\circ} \mathrm{C}$ and finally resuspended in $15 \mu \mathrm{l} \mathrm{X}$ 
SDS sample buffer. The precipitated chromatin and the prespin pellet were separated by SDS-PAGE (2.3.1.2) and analyzed by immunoblotting (2.3.1.4).

\subsubsection{Monitoring of second strand synthesis}

The conversion from ssDNA to dsDNA during chromatin assembly was monitored by incorporation of $\left[\alpha-{ }^{32} \mathrm{P}\right] \mathrm{dATP}(3000 \mathrm{Ci} / \mathrm{mmol})$. As a negative control, second strand synthesis was blocked with $100 \mu \mathrm{g} / \mathrm{ml}$ aphidicolin. A standard assembly mix was set up including $0.15 \mu 1\left[\alpha-{ }^{32} \mathrm{P}\right] \mathrm{dATP}$. The reaction was stopped by adding $500 \mu \mathrm{l}$ cold PB buffer and the DNA was purified using the Qiagen PCR purification kit according to the manufacturer's protocol. The eluted DNA was counted in a Liquid Scintillation Analyzer and analyzed by agarose gel electrophoresis (2.2.1.2).

\subsubsection{Topological assays of HSE-derived chromatin}

Topological assays in the Xenopus laevis egg extract have been performed on the basis of [148].

\subsubsection{Supercoiling assay}

Supercoiling assay was used to monitor chromatin assembly over a time-course of $4 \mathrm{~h}$ at $23^{\circ} \mathrm{C}$. After $15 \mathrm{~min}, 30 \mathrm{~min}, 1 \mathrm{~h}, 2 \mathrm{~h}, 3 \mathrm{~h}$ and $4 \mathrm{~h}$ an aliquot corresponding to 300 ng DNA was removed from the assembly mix (2.4.2.1) and transferred to an Eppendorf tube containing an equal amount of Stop mix 1 (30 mM EDTA, 0.7\% [w/v] SDS). The volume was adjusted to $100 \mu \mathrm{l}$ using $\mathrm{ddH}_{2} \mathrm{O}$. First $5 \mu 1 \mathrm{RNase} A$ $\left(2 \mathrm{mg} / \mathrm{ml}\right.$ ) was added for $30 \mathrm{~min}$ at $37^{\circ} \mathrm{C}$, followed by addition of $5 \mu$ l Proteinase $\mathrm{K}$ $(4 \mathrm{mg} / \mathrm{ml})$ for $30 \mathrm{~min}$ at $37^{\circ} \mathrm{C}$. The DNA was extracted with $110 \mu \mathrm{l}$ phenol:chloroform:isoamyl alcohol [25:24:1] in a $2 \mathrm{ml}$ phase lock gel tube. The upper phase $[\sim 100 \mu \mathrm{l}]$ was collected and precipitated with 1 volume of $5 \mathrm{M}$ ammonium acetate, 4 volumes of ice-cold $100 \%$ ethanol and $1 \mu \mathrm{l}$ glycogen $(20 \mathrm{mg} / \mathrm{ml})$. The DNA-ethanol mix was incubated overnight at $-20^{\circ} \mathrm{C}$, centrifuged for $45 \mathrm{~min}$ $16,000 \mathrm{xg}$ at $4^{\circ} \mathrm{C}$ and washed twice with $800 \mu 1$ cold $70 \%$ ethanol. The resulting pellet was quickly dried in a SpeedVac for 15 min and resuspended in $15 \mu 1 d^{d d} \mathrm{H}_{2} \mathrm{O}$. $5 \mu 1$ DNA loading dye was added and the DNA was loaded on a $1.2 \%$ agarose gel in $1 \mathrm{X}$ TAE. The gel was run in the absence of ethidium bromide for $20 \mathrm{~h}$ at $1.5 \mathrm{~V} / \mathrm{cm}$ at 
$4^{\circ} \mathrm{C}$. The DNA pattern was visualized by soaking the gel in $0.5 \mu \mathrm{g} / \mathrm{ml}$ ethidium bromide for $45 \mathrm{~min}$ at RT followed by a destaining step for 30-45 min in $\mathrm{ddH}_{2} \mathrm{O}$.

\subsubsection{MNase digestion}

A chromatin assembly reaction was set up as described (2.4.2.1) and scaled up 9-fold [225 $\mu 1]$. The reaction was allowed to proceed for $4 \mathrm{~h}$ at $23^{\circ} \mathrm{C} .30 \mu \mathrm{l}$ of the assembly

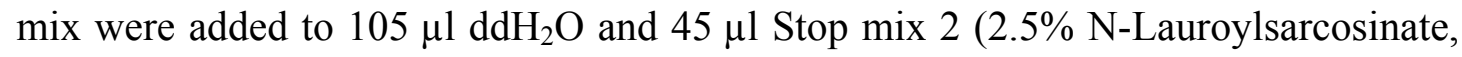
$100 \mathrm{mM}$ EDTA) and set aside as input control.

A digestion mix was prepared by mixing the assembly reaction $[\sim 195 \mu 1]$ with $600 \mu 1$ MNase buffer (10 mM HEPES-KOH pH 7.6, $50 \mathrm{mM} \mathrm{KCl,} 1.5 \mathrm{mM} \mathrm{MgCl} 2,0.5 \mathrm{mM}$ EDTA, 10\% [v/v] glycerol, $10 \mathrm{mM} \beta$-glycerophosphate, $1 \mathrm{mM}$ DTT), $30 \mu 1100 \mathrm{mM}$ $\mathrm{CaCl}_{2}$ and $13.5 \mu \mathrm{l}$ MNase at $10 \mathrm{U} / \mu \mathrm{l}$. This mix was incubated at RT and $150-\mu 1$ aliquots were removed after $30 \mathrm{~s}, 45 \mathrm{~s}, 90 \mathrm{~s}, 5 \mathrm{~min}$ and $30 \mathrm{~min}$. The samples were immediately transferred to corresponding tubes containing $50 \mu 1$ Stop mix 2 . The MNase samples as well as the input were digested with $15 \mu 1 \mathrm{RNase} A(2 \mathrm{mg} / \mathrm{ml})$ for $30 \mathrm{~min}$ at $37^{\circ} \mathrm{C}$. The samples were further treated with $7.5 \mu 1$ Proteinase $\mathrm{K}(10 \mathrm{mg} / \mathrm{ml})$ and $11.5 \mu 110 \%$ SDS. This mixture was incubated for $15 \mathrm{~h}$ at $37^{\circ} \mathrm{C}$. The DNA was extracted with $235 \mu \mathrm{l}$ phenol:chloroform:isoamyl alcohol [25:24:1] in a $2 \mathrm{ml}$ phase lock gel tube. The aqueous phase $[\sim 210 \mu l]$ was withdrawn and supplemented with $1 / 10$ volume $3 \mathrm{M}$ sodium acetate $\mathrm{pH} 5.2,3$ volumes ice-cold $100 \%$ ethanol and $1 \mu 1$ glycogen $(20 \mathrm{mg} / \mathrm{ml})$. The DNA-ethanol solution was incubated overnight at $-20^{\circ} \mathrm{C}$, centrifuged for $45 \mathrm{~min} 16,000 \mathrm{xg}$ at $4^{\circ} \mathrm{C}$ and washed three times with $800 \mu \mathrm{l}$ cold $70 \%$ ethanol. The DNA pellet was quickly dried in a SpeedVac and resuspended in $10 \mu 1 \mathrm{ddH}_{2} \mathrm{O} .3 \mu 1$ 10X DNA loading dye were added and the DNA was loaded on a $1.3 \%$ agarose gel with small pockets. The gel was run in $1 \mathrm{X}$ TBE at 50-60 V at RT until the bromphenol blue was approximately $2 \mathrm{~cm}$ from the bottom of the gel. The gel was stained for $30 \mathrm{~min}$ in $0.5 \mu \mathrm{g} / \mathrm{ml}$ ethidium bromide and destained for $45 \mathrm{~min}$ in $\mathrm{ddH}_{2} \mathrm{O}$.

\subsubsection{Purification of chromatin by sucrose density gradient centrifugation}

Linear sucrose gradients were prepared in $2.2 \mathrm{ml}$ thin-wall ultracentrifuge tubes using a gradient master (Bio-Comp, model 107ip). Therefore, two sucrose buffers containing either $10 \%$ or $40 \%$ [w/v] sucrose were prepared in GB50 (20 mM HEPES- 
$\mathrm{KOH} \mathrm{pH} \mathrm{7.8,} 50 \mathrm{mM} \mathrm{KCl,} 0.4 \mathrm{mM}$ EDTA, $1 \mathrm{mM}$ DTT, complete protease inhibitor cocktail). The $10 \%$ solution was first layered into each tube and the $40 \%$ solution was poured beneath it as described in the manufacturer's protocol. Tubes were capped and the gradient was formed at a speed of $15 \mathrm{rpm}$ for 2:04 min at an angle of $81.5^{\circ}$. The gradients were allowed to cool down to $4^{\circ} \mathrm{C} .150 \mu$ were removed from top before $200 \mu 1$ of an assembly mix were loaded on top of the gradient. The gradient was centrifuged for $75 \mathrm{~min}$ at $55,000 \mathrm{rpm}$ in a S55-S rotor at $4^{\circ} \mathrm{C}$. The gradient was fractionated manually by removing $150 \mu 1$ fractions from top to bottom.

\subsubsection{Identification of chromatin-containing fractions}

For analysis by Western blot (2.3.1.4) gradient fractions were precipitated with $6 \mathrm{mM}$ $\mathrm{MnCl}_{2}$ as described (2.4.3) and separated by SDS-PAGE.

For quick analysis, $10 \%$ of each fraction was supplemented with $0.1 \mathrm{mg} / \mathrm{ml} \mathrm{RNase} \mathrm{A}$ and the volume was adjusted with $\mathrm{ddH}_{2} \mathrm{O}$ to $60 \mu \mathrm{l}$. The samples were incubated for $30 \mathrm{~min}$ at $37^{\circ} \mathrm{C}$. To each fraction $5 \mu \mathrm{l}$ ethidium bromide $(6.5 \mu \mathrm{g} / \mathrm{ml})$ were added, the sample was transferred to a 96 well plate and fluorescence emission was measured using a $355 \mathrm{~nm}$ excitation filter and a $615 \mathrm{~nm}$ emission filter [149]. After subtraction of blank values the relative fluorescence units were blotted against the fraction numbers to determine chromatin peaks.

In some cases, samples were further treated with $0.1 \mathrm{mg} / \mathrm{ml}$ Proteinase $\mathrm{K}$ and $3 \% \mathrm{SDS}$ for $30 \mathrm{~min}$ at $37^{\circ} \mathrm{C}$. The volume was increased to $100 \mu \mathrm{l}$ with $\mathrm{ddH}_{2} \mathrm{O}$ and DNA was deproteinized by phenol-chloroform extraction and precipitated by adding 2.5 volumes ethanol, $0.3 \mathrm{M}$ sodium acetate $\mathrm{pH} 5.2$ and $1 \mu$ glycogen. Samples were analyzed by agarose gel electrophoresis.

\subsubsection{Transcriptional analysis of chromatin}

\subsubsection{Transcription assay}

Chromatin-containing fractions from a sucrose gradient centrifugation (2.4.6) were dialyzed in Slyde-A-Lyzer tubes (MWCO 10,000) for $24 \mathrm{~h}$ at $4^{\circ} \mathrm{C}$ against TX50 buffer (20 mM HEPES-KOH pH 7.8, $50 \mathrm{mM} \mathrm{KCl,} 0.1 \mathrm{mM}$ EDTA, $1 \mathrm{mM}$ DTT). Chromatin-containing fractions were pooled and concentrated to about $2 \mathrm{ng} / \mu \mathrm{l}$ DNA in Amicon filter devices (MWCO 10,000).

A transcription reaction [50 $\mu 1]$ was set up according to [130] with modifications. 
$25 \mu \mathrm{l}$ chromatin [50 ng] or $50 \mathrm{ng}$ naked DNA were incubated with $1 \mu \mathrm{l}$ GAL4-VP16 [25 ng, Jena Bioscience], $1 \mu \mathrm{l}$ Trichostatin A (4 mM) and $1 \mu \mathrm{l}$ Rasin (40 U/ $\mu \mathrm{l})$ for $20 \mathrm{~min}$ at $27^{\circ} \mathrm{C}$. Then, $1 \mu \mathrm{DTT}(0.25 \mathrm{M}), 2.5 \mu \mathrm{HM}$ buffer (400 mM HEPES-KOH pH 7.8, 100 mM MgCl ), $2.5 \mu 1$ BC200 (20 mM HEPES-KOH pH 7.8, 200 mM KCl, 20\% glycerol, $0.2 \mathrm{mM}$ EDTA, 1mM DTT, $0.5 \mathrm{mM}$ PMSF), $1 \mu 1$ acetyl-CoA $(0.5 \mathrm{mM})$ and $1 \mu \mathrm{l} 300$ [25-50 ng] were added and the reaction was incubated for $30 \mathrm{~min}$ at $30^{\circ} \mathrm{C} .5 \mu \mathrm{HeLa}$ nuclear extract (2.4.7.2) was added and incubation was continued at $30^{\circ} \mathrm{C}$ for $15 \mathrm{~min}$. Transcription was started by addition of $2.5 \mu 1$ NTPs (12 mM ATP/GTP/UTP, $0.5 \mathrm{mM} \mathrm{CTP),} 1 \mu \mathrm{l}$ Rasin (40 U/ $\mu \mathrm{l})$ and $1 \mu \mathrm{l}\left[\alpha^{32} \mathrm{P}\right] \mathrm{CTP}$ $(3000 \mathrm{Ci} / \mathrm{mmol})$. The reaction was allowed to proceed for $45 \mathrm{~min}$ at $30^{\circ} \mathrm{C}$ before addition of $2 \mu \mathrm{RNaseT} 1(10 \mathrm{U} / \mu \mathrm{l})$ for $15 \mathrm{~min}$ at $30^{\circ} \mathrm{C}$. The volume was filled up to $100 \mu \mathrm{l}$ with $\mathrm{ddH}_{2} \mathrm{O}$ and the RNeasy purification kit was used to purify RNA according to the manufacturer's instructions. Radioactive RNA molecules were dried in a SpeedVac, analyzed by urea-PAGE (2.2.1.4) and visualized by autoradiography (2.4.7.3).

\subsubsection{Preparation of transcription-competent HeLa nuclear extract}

HeLa S3 cells were grown in suspension in a bioreactor at logarithmic growth rate in S-MEM medium (Gibco BRL), supplemented with 5\% [v/v] newborn calf serum (Gibco BRL), $50 \mu \mathrm{g} / \mathrm{ml}$ penicillin and $100 \mu \mathrm{g} / \mathrm{ml}$ streptomycin. Cultivation of cells and preparation of HeLa nuclear extract was performed by Thomas Conrad and Hossein Kohansal (Lührmann department, Max Planck Institute for Biophysical Chemistry, Göttingen) essentially as described elsewhere [150, 151].

\subsubsection{Autoradiography and Phosphor Imager analysis}

Polyacrylamide gels as well as agarose gels containing ${ }^{32} \mathrm{P}$-labeled material were vacuum-dried in a gel dryer prior to exposure to autoradiography. Therefore, ureaPAGE gels were fixed for $2 \mathrm{~min}$ in $10 \%$ acetic acid/ $40 \%$ methanol, placed on Whatman paper and dried for $2 \mathrm{~h}$ at $80^{\circ} \mathrm{C}$. Agarose gels were fixed for $10 \mathrm{~min}$ in $10 \%$ acetic acid/ $10 \%$ methanol and dried on Whatman paper for $1 \mathrm{~h}$ at $80^{\circ} \mathrm{C}$. Gels were covered with plastic wrap and exposed against a Storage Phosphor screen until the desired visualization level was achieved. Analysis was performed with a Typhoon Phosphor Imager and the program ImageJ (http://rsb.info.nih.gov/ij/).

SDS-PAGE gels containing ${ }^{3}$ H-labeled proteins (2.3.2.9) were stained with Coomassie Brilliant Blue and destained as described (2.3.1.3). After destaining the gel 
was soaked in five gel volumes EN3HANCE (Perkin Elmer) for $1 \mathrm{~h}$ at RT. The autoradiography enhancer solution was decanted and the scintillator fluor was precipitated in the gel with cold $1 \%$ glycerol $/ 10 \%$ PEG 8000 for $30-60 \mathrm{~min}$ at RT. The gel was dried for $2 \mathrm{~h}$ at $80^{\circ} \mathrm{C}$ on Whatman paper and exposed against a Kodak BioMax MR film at $-80^{\circ} \mathrm{C}$ until the desired visualization level was achieved. The film was developed using a Kodak X-Omat 2000 processor.

\subsection{Special methods}

\subsubsection{Mass spectrometry of chromatin-associated proteins and histone modifications}

Identification of chromatin-associated proteins by mass spectrometry was performed in the group of Henning Urlaub (Max Planck Institute for Biophysical Chemistry, Göttingen). Proteins were separate by SDS-PAGE in the NuPAGE precast system, stained with colloidal Coomassie $(0.02 \%$ [w/v] Coomassie G250, 5\% [w/v] aluminum sulfate, $10 \%[\mathrm{v} / \mathrm{v}]$ ethanol, $2 \%[\mathrm{v} / \mathrm{v}]$ orthophosphoric acid) and entire lanes were cut into 23 equally sized pieces. An in-gel digest with trypsin was performed according to [152] and extracted peptides were analyzed by LC-coupled tandem mass spectrometry on an Orbitrap Xl mass spectrometer. The MASCOT search engine (taxonomy filter Xenopus laevis) was used to search CID fragment spectra against the NCBInr database. Output files were analyzed and subtracted from each other based on their ginumbers using the program R (www.r-project.org/).

Histone modifications were analyzed by Axel Imhof (Adolf-Butenandt Institute, LMU, München). Therefore, chromatin was purified by sucrose gradient centrifugation, precipitated with $\mathrm{MnCl}_{2}$ and separated on a $15 \%$ acrylamide gel by SDS-PAGE. Individual histone bands were cut out and analyzed according to methods described in [153].

\subsubsection{Atomic force microscopy (AFM) of chromatin}

Structural properties of different chromatin species were investigated by AFM after purification of chromatin assemblies by sucrose density gradient centrifugation (2.4.6). Fractions containing chromatin were dialyzed against AFM buffer (10 mM Triethanolamine $\mathrm{pH} 7.5,50 \mathrm{mM} \mathrm{NaCl}, 1 \mathrm{mM} \mathrm{DTT})$ for $24 \mathrm{~h}$ at $4^{\circ} \mathrm{C}$. The chromatin- 
containing fractions were crosslinked with $0.6 \%[\mathrm{v} / \mathrm{v}]$ glutaraldehyde (EM-grade) for $40 \mathrm{~min}$ on ice and then dialyzed overnight against AFM buffer (-DTT) to remove excess glutaraldehyde. $20 \mu \mathrm{l}$ of the crosslinked material was spotted on a freshly cleaved mica (Plano), rinsed 3 times with $1 \mathrm{ml}$ with $\mathrm{ddH}_{2} \mathrm{O}$ and air-dried for $10 \mathrm{~min}$. Imaging was performed by Nils Kost (Chromatin Biochemistry, Max Planck Institute for Biophysical Chemistry) on a Nanoscope V Multi Mode AFM as described previously $[154,155]$. 


\section{Results}

Every eukaryotic cell encounters assembly and disassembly of chromatin structures at all cell cycle stages. Over the last years it has become evident that different pathways are involved in accomplishing this enormous logistic task: An replication-coupled assembly pathway like in S-phase and an assembly pathway that functions independent of any DNA synthesis. However, little is known about how these distinct assembly pathways contribute to certain chromatin structures and functions or if these structures are the consequence of pathways downstream of assembly. To gain more insights into the features introduced on chromatin by each pathway I first set up a chromatin assembly system in Xenopus laevis egg extracts that is capable of performing chromatin assembly by both pathways.

\subsection{Replication-coupled and replication-independent assembly in a cell-free system}

In the literature several chromatin reconstitution systems have been described. From purely recombinant systems using salts dialysis to form chromatin [135], over combinations of viral components with cellular extracts $([79,156])$ to cellular extract systems that autonomously assemble chromatin on introduced DNA sequences. Since the recombinant in vitro system is not suitable for DNA-synthesis assembly pathways and the viral (SV40) system only mediates replication-coupled assembly, I decided to work with a cellular extract system. Basically, two systems exist: Drosophila embryonic extracts [93] and extracts derived from Xenopus laevis eggs or oocytes [86]. Both systems autonomously assemble chromatin on introduced DNA sequences in a replication-coupled or replication-independent manner. Furthermore, they are open to biochemical manipulations like supplementation, depletion and substitution.

\subsubsection{Establishment of a chromatin assembly system in Xenopus laevis egg extracts}

A variety of Xenopus egg and oocyte extracts has been described in the literature (see [96] for review). I prepared a cytoplasmatic high-speed egg extract (HSE) that is 
capable of performing chromatin assembly and complementary second strand synthesis but in comparison to crude extracts has lost the ability to form nuclear structures and replicate double-stranded DNA [91, 92, 157-159].

Xenopus egg extracts were derived from mature eggs (arrested at metaphase II of meiosis) that were spawn by female frogs upon stimulation with human chrorionic gonadotropin. Frog eggs were collected and crushed by centrifugation at high $g$-forces (Figure 3.1A). After the first centrifugation step a low-speed extract (LSE) was withdrawn, which is already competent for chromatin assembly but cannot be stored for a prolonged period of time. After a subsequent centrifugation step the cytoplasmatic high-speed extract (HSE) was obtained and used for all chromatin assemblies described in this work. It is important to notice that both extracts (LSE and HSE) are DNA-free since the highly condensed metaphase chromosomes are pelleted during centrifugation [86, 87].

For chromatin assembly the extract was supplemented with an ATP-regenerating system and circular DNA constructs (either with pUC19 as in Figure 3.1 or with constructs described under 3.1.2). The assembly process was monitored by the degree of supercoiling introduced on a circular DNA template upon assembly. Within the first 10 minutes after addition to the HSE, the naked, negatively supercoiled plasmid DNA is almost completely relaxed due topoisomerase activity of the extract (Figure 3.1B top panel [91]). During the further course of assembly each nucleosome formed on the plasmid introduces a negative supercoil, which is reflected by the presence of distinct topoisomers. The successive increase in supercoiling and thus assembly leads to fully supercoiled DNA that shows a similar degree of supercoiling as observed for the naked DNA preparations from bacteria (compare time points 0 min and $4 \mathrm{~h}$, Figure 3.1B, top panel).

To further confirm chromatin integrity I digested the assembled chromatin with Micrococcal nuclease (MNase). This nonspecific endo-/exonuclease preferentially cuts the linker DNA, the most accessible regions within the chromatin fiber [160]. The digestion of chromatin thus released fragments of different size as depicted by the ladder-like appearance of the extracted DNA fragments in an ethidium bromide stained agarose gel (Figure 3.1B, lower panel). The smallest DNA fragments that were generated after the first time point corresponded to about $200 \mathrm{bp}$. This DNA size represents the average nucleosomal repeat length including linker DNA, i.e., the amount of DNA that is protected by one octamer plus linker histone. This entity, the 
nucleosome, has been described in previous reports to contain about $200 \mathrm{bp}$ of DNA in Xenopus laevis [92]. Ongoing cleavage finally resulted in accumulation of DNA fragments smaller than $200 \mathrm{bp}$ as demonstrated by a downward shift of fragments size in the agarose gel (Figure 3.1B, lower panel, last lane). This shift corresponds to the loss of linker histone, which goes along with further digestion of linker DNA down to the nucleosomal core particle (147 bp DNA).

A

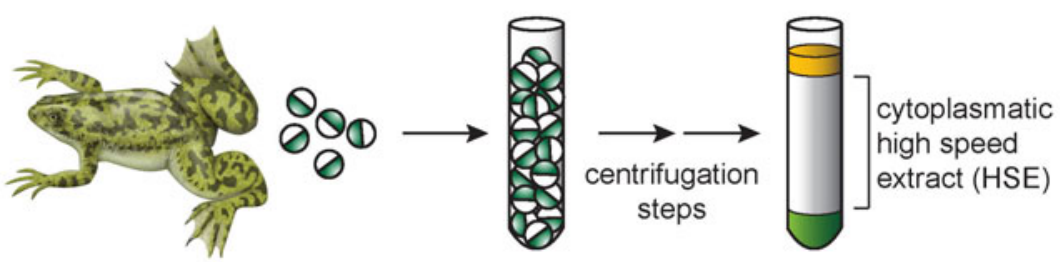

B

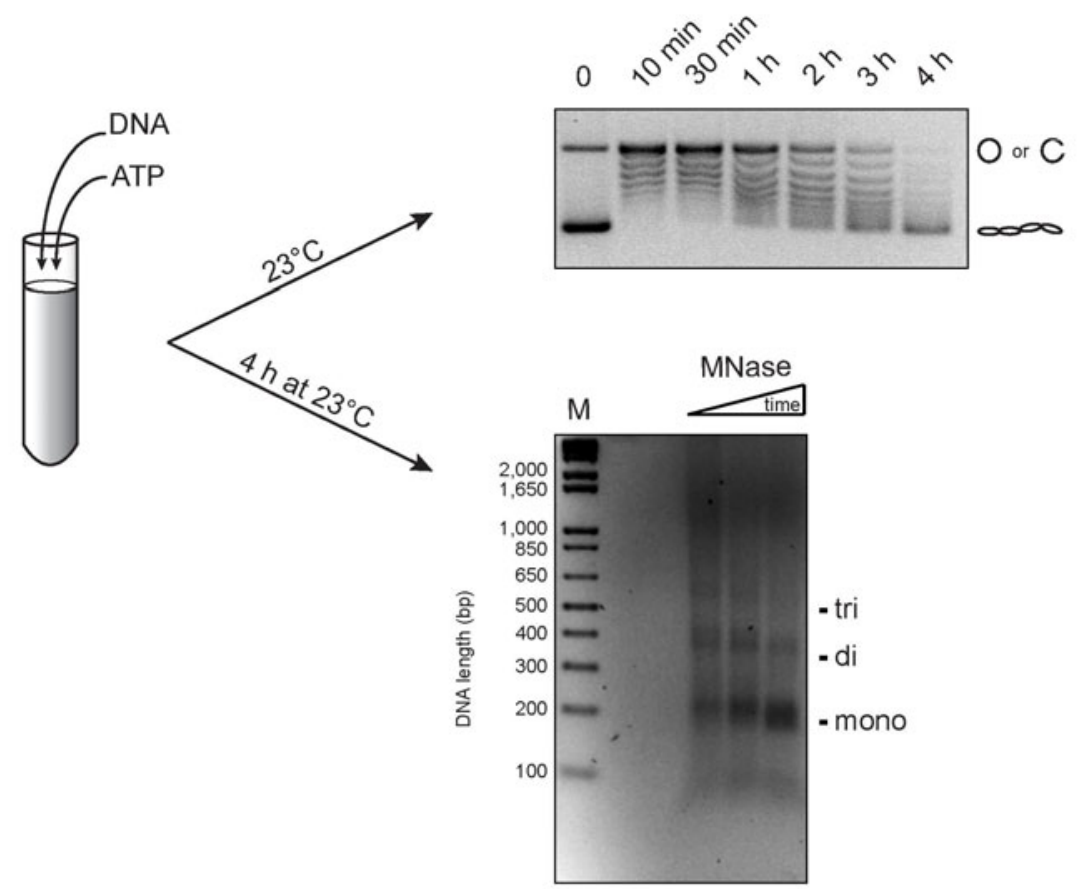

Figure 3.1 | Chromatin is assembled in Xenopus egg extract. (A) Schematic overview of Xenopus laevis egg extract preparation. Freshly laid eggs are collected and fractionated by step-wise centrifugation to obtain a high-speed extract (HSE; for details see material and methods). (B) Chromatin is assembled in the extract upon addition of DNA and an ATP-regenerating system. The degree of nucleosome assembly is monitored by a supercoiling assay or MNase digest. Top: pUC19 DNA was extracted and purified at increasing time points after DNA addition and run on an agarose gel (ethidium bromide stained). Positions of the supercoiled (multiple circles) and the nicked or closed relaxed forms (closed/open circle) are indicated. Bottom: Micrococcal nuclease (MNase) digest was performed after $4 \mathrm{~h}$ of assembly at $23^{\circ} \mathrm{C}$. Assembled pUC19 (300 ng) was treated with $30 \mathrm{U}$ MNase for either $30 \mathrm{~s}, 45 \mathrm{~s}$ or $90 \mathrm{~s}$. DNA fragments were extracted and analyzed on an agarose gel (ethidium bromide stained). The positions of DNA fragments corresponding to mono-, di-, tri-nucleosomal structures are indicated (lane M - DNA size standard). 
In general, chromatin assembly was completed after $4 \mathrm{~h}$ at $23^{\circ} \mathrm{C}$. By applying supercoiling assays and MNase digestion I verified that the prepared egg extract (HSE) assembles nucleosomal structures on the introduced DNA template. Moreover, chromatin assembly mediated by the extract goes to completion as judged from the maximal degree of DNA supercoiling observed in the experiment. The MNase digest pattern revealed that the average nucleosomal repeat length including linker DNA is about $200 \mathrm{bp}$, which is in good agreement with previous reports. I thus concluded that the generated frog egg extracts represents a bona fide assembly system.

\subsubsection{Construction of DNA templates suitable for replication-coupled and replication-independent chromatin assembly}

$X$. laevis high-speed egg extracts (HSE) are capable of assembling chromatin on double-stranded (ds)DNA and on single-stranded (ss)DNA after second strand synthesis. While the dsDNA represents a replication-independent assembly (RI assembly), ssDNA resembles a replication-coupled (RC) assembly. This process is regulated by enzymes similar to those for lagging-strand synthesis at the replication fork [87].

Since the egg extract shows exonuclease activity on linear DNA fragments (Hironori Funabiki, Rockefeller University, USA, personal communication) I decided to work with circular templates. Moreover, a circular construct carrying a phage origin of replication (phagemid vector) can be produced in a single-stranded manner with the help of phages (see below).

Based on the pBluescriptII SK(-) phagemid vector I created a construct (pBS-G ${ }_{5} \mathrm{ML}$ ) carrying a cassette of the $\mathrm{pG}_{5} \mathrm{ML}$ plasmid (Woojin An, USC, USA). This cassette contains a transcriptional unit consisting of five GAL4 upstream activator sequences (UAS) for recruitment of GAL4-fusion proteins, a strong adenovirus-2 major late (AdML) promoter and a $380 \mathrm{bp}$ G-less cassette (Figure 3.2A). The latter one is a synthetic DNA fragment without cytidine residues on the transcribed strand, i.e. its transcripts are free of guanidine $(\mathrm{G})$ residues. It is therefore not digested by a Gspecific RNase (RNaseT1) [137]. Using the pBS-G ${ }_{5} \mathrm{ML}$ phagemid I was able to amplify dsDNA in E. coli and produce ssDNA by infection of E. coli DH12S cells with the helper phage M13K07 (Figure 3.2B/C). 
A

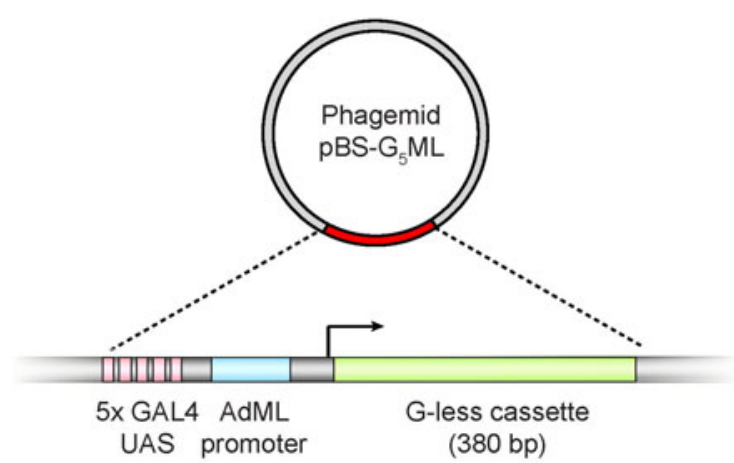

B

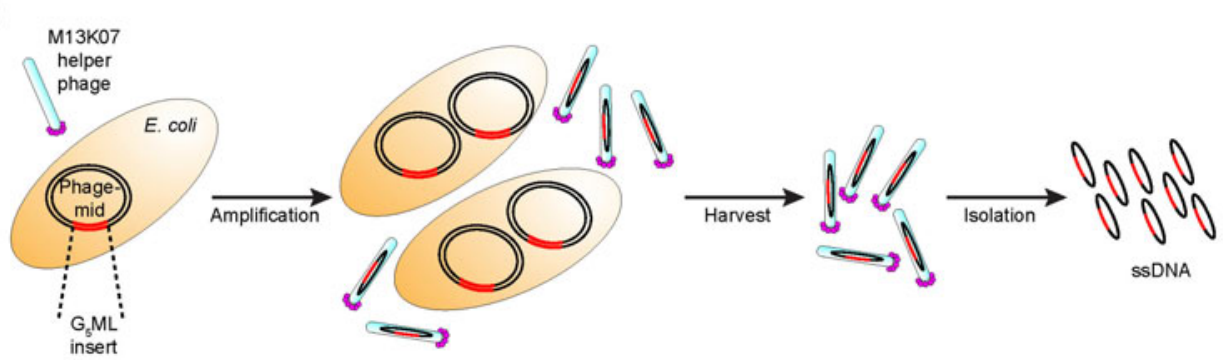

C

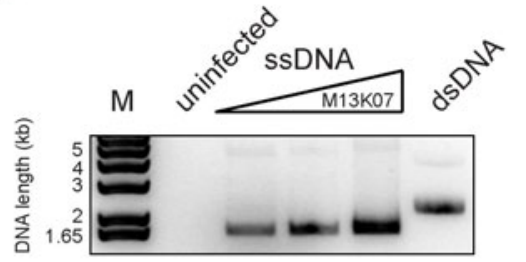

D

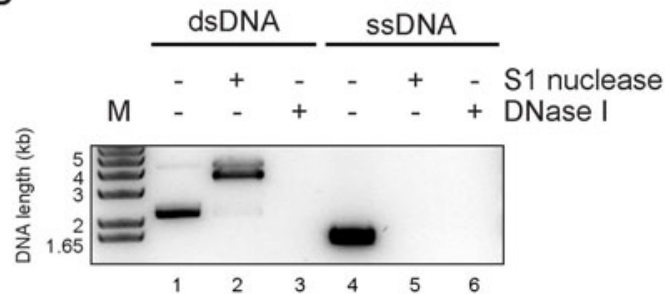

Figure 3.2 | Preparation of double-stranded and single-stranded DNA templates. (A) Schematic representation of the $\mathrm{G}_{5} \mathrm{ML}$ cassette inserted into the $\mathrm{pBS}-\mathrm{G}_{5} \mathrm{ML}$ phagemid (UAS - upstream activator sequence, AdML - adenovirus-2 major late). (B) M13K07 helper phage is used to infect DH12S cells carrying $\mathrm{pBS}-\mathrm{G}_{5} \mathrm{ML}$. The replicative, double-stranded (ds)DNA form is amplified and maintained in the $E$. coli cells whereas the single-stranded (ss)DNA is packaged into phage structures and secreted. The secreted phages are harvested by PEG-precipitation and ssDNA is extracted (see material and methods for detail). (C) DH12S cells were infected with increasing amounts of M13K07 (3 x 10 $0^{8}$, $5 \times 10^{8}, 10 \times 10^{8}$ phage/ml), ssDNA was extracted and subjected to agarose gel electrophoresis and analyzed by staining with ethidium bromide. As a control uninfected cells and dsDNA ( $50 \mathrm{ng}$ ) were loaded. (D) dsDNA and ssDNA were digested with DNaseI and S1 nuclease. Reactions were analyzed together with untreated dsDNA and ssDNA on an agarose gel and stained with ethidium bromide (lane M - DNA size standard).

The prepared DNA populations were analyzed by agarose gel electrophoresis and by digest with specific nucleases. Agarose gel electrophoresis showed that ssDNA migrates faster in an agarose gel than dsDNA of the same size (Figure 3.2D lane 1 and 4), which is in agreement with observations from the literature [161]. Digest with DNase I revealed that both DNA preparations were free of potentially contaminating RNA molecules since no nucleic acids were visible after digest on an ethidium bromide stained agarose gel (Figure 3.2D lane 3 and 6). DNase I is a rather unspecific 
DNA endonuclease that cuts dsDNA as well as ssDNA. I thus used S1 nuclease that only digests ssDNA but cannot digest dsDNA. This digest demonstrated that the prepared ssDNA was completely digested by S1 nuclease whereas dsDNA preparations were nicked but not digested (Figure 3.2D lane 2 and 5).

Importantly, these experiments showed that with the described strategy, using helper phage infection, I was able to purify homogenous ssDNA and dsDNA populations. These homogenous DNA preparations are essential for the below described chromatin assembly reactions to prevent an intermingling of the two assembly pathways.

\subsubsection{Chromatin can be retrieved from the egg extract by precipitation}

To extend the analysis from the described topological assays to biochemical and functional analyses I sought of a way to retrieve chromatin from the extract. An immobilization and pullout strategy cannot be applied straightforward to a circular template and I decided to precipitate the assembled chromatin for biochemical analyses. From the literature it is known that divalent cations like $\mathrm{Mg}^{2+}, \mathrm{Mn}^{2+}$ or $\mathrm{Zn}^{2+}$ can promote self-association of chromatin fragments (Figure 3.3A, [162, 163]). The potential of compaction is dependent on the cation type and is highest when $\mathrm{Mn}^{2+}$ ions are present [164].

I discovered that $\mathrm{MnCl}_{2}$ concentrations of $5 \mathrm{mM}$ were sufficient to specifically precipitate chromatin fibers from the extract. The precipitated chromatin was analyzed by Western blot with anti-histone $\mathrm{H} 3$ antibodies (Figure 3.3B/C). An increase in cation concentration was thereby reflected by increasing amounts of precipitated histone proteins. In parallel, I treated mock assembly reaction, i.e., assembly reactions without DNA, the same way. This revealed that $\mathrm{MnCl}_{2}$ concentrations $\geq 10 \mathrm{mM}$ caused precipitation of histones in mock assembly reactions containing no DNA (Figure 3.3B lower panel). I believe this is due to unspecific interactions of free histones with the high amount of RNA present in the extract. Therefore, all precipitations presented in this study were performed with $6-8 \mathrm{mM} \mathrm{MnCl}_{2}$ to prevent saturation with $\mathrm{MnCl}_{2}$ and thus precipitation of non-chromatinized histone proteins.

After I had established the precipitation procedure I carried on to compare chromatin derived from dsDNA and ssDNA on basis of their histone content. Immunoblots on precipitated chromatin against histone proteins $\mathrm{H} 3$ and $\mathrm{H} 4$ as well as Ponceau staining demonstrated that the DNA templates used in the two assembly pathways contain 
similar amounts of histone proteins (Figure 3.3C). This indirectly argued for similar saturation levels of DNA with nucleosomal particles. In both assembly pathways the extract incorporates a special maternal form of the linker histone H1 named B4. This maternal $\mathrm{H} 1$ histone is the only $\mathrm{H} 1$ variant present in the egg at early developmental stages. It is later replaced by the somatic variants [165-167].

The precipitation strategy showed that chromatin fibers were specifically precipitated by addition of $5-8 \mathrm{mM} \mathrm{MnCl}_{2}$. Chromatin assembled by the two pathways and retrieved in this way showed a similar amount of incorporated core histones and linker histones. Considering the comparable amounts of histones detected in the two different chromatin assembly pathways I further investigated if structural differences can be distinguished by topological assays like supercoiling and MNase digest.

A

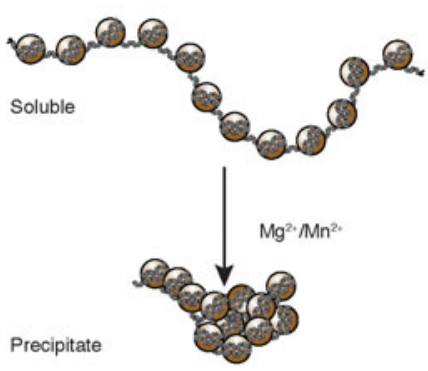

C

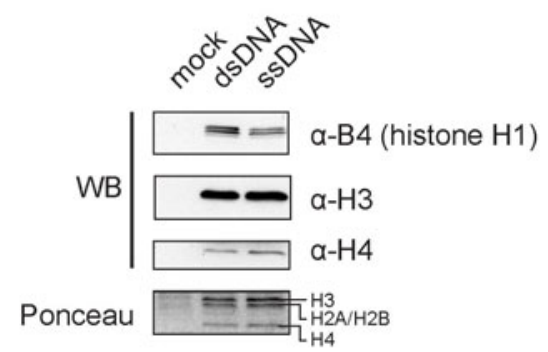

B

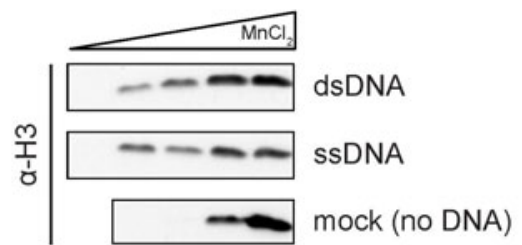

Figure 3.3 | Extract assembled chromatin is precipitated by divalent cations. (A) Chromatin is compacted by $\mathrm{Mg}^{2+}$ or $\mathrm{Mn}^{2+}$ ions and can be recovered by centrifugation. (B) dsDNA and ssDNA were assembled in HSE extract and precipitated with $0,5,7.5,10$ or $15 \mathrm{mM} \mathrm{MnCl}_{2}$. In parallel, a mock assembly without DNA was treated with $5,7.5,10$ or $15 \mathrm{mM} \mathrm{MnCl}_{2}$. The precipitate was analyzed with anti-H3 antibodies in Western blots. (C) Chromatin was assembled in HSE on dsDNA or ssDNA. The chromatin and the mock assembly reactions were precipitated with $8 \mathrm{mM} \mathrm{MnCl} 2$ and analyzed by Western blot (WB) with anti-B4 (maternal linker histone), anti-H3 and anti-H4 antibodies. 


\subsection{Topological and structural characterization of chromatin species}

\subsubsection{RI and RC assembled chromatin have comparable topological properties}

In general, the degree of supercoiling of a plasmid extracted from chromatin samples reflects the degree of assembly as well as the saturation level of DNA with octamers. I examined both chromatin species in a supercoiling assay and additionally by MNase digestion to analyze the properties of each assembly. The RI assembly on dsDNA proved to be relatively slow and only reached completion after $4 \mathrm{~h}$ (Figure 3.4A, Figure 3.1B). During assembly a distinct number of topoisomers were detected corresponding to the linking number of the plasmid and reflecting increasing amounts of deposited histones. At the endpoint of assembly $>95 \%$ of the DNA template was fully supercoiled (Figure 3.4A upper panel, time point $4 \mathrm{~h}$ ).

I did not observe the same amount of topoisomers for the RC assembly on ssDNA. Furthermore, the conversion of ssDNA to dsDNA rapidly occured between $30 \mathrm{~min}$ and $2 \mathrm{~h}$ post addition of DNA to the extract (Figure 3.4A lower panel, Figure 3.5B). Since histone deposition is tightly coupled to DNA synthesis during replication, only a single shift from naked ssDNA to supercoiled dsDNA was noticed after $1 \mathrm{~h}$ incubation but no distinct intermediate topoisomers. While there was still little ssDNA present at the $1 \mathrm{~h}$ time point, after $2 \mathrm{~h}$ all ssDNA had been converted to dsDNA and no further changes were detected. A distinct dsDNA intermediate topoisomer was reproducibly found in the RC assembly that showed less supercoiling than the fully supercoiled form but did not represent a fully relaxed topoisomer (Figure 3.4A lower panel).

MNase digests of chromatin assembled by both pathways in the extract showed a similar overall digestion pattern using equal amounts of MNase and chromatin (Figure 3.4B). The nucleosomal repeat length was about 180-200 bp for both species. However, the ssDNA-derived chromatin showed a slightly smaller fragment size compared to the dsDNA/chromatin already at early time points. It could not be revealed at this point whether the slight differences revealed by MNase digest were due to shorter nucleosomal repeat lengths of ssDNA-derived chromatin or whether this type of chromatin is less well protected by associated proteins. Since the detected 
amounts of histone proteins and thus saturation level of DNA with nucleosomes were comparable the latter explanation seems to be more reasonable.

A
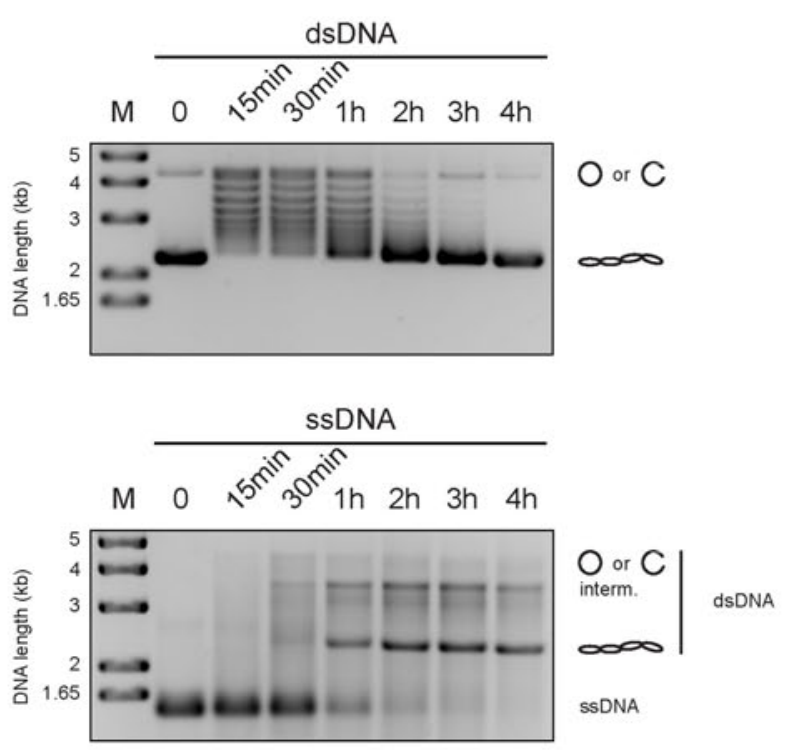

B
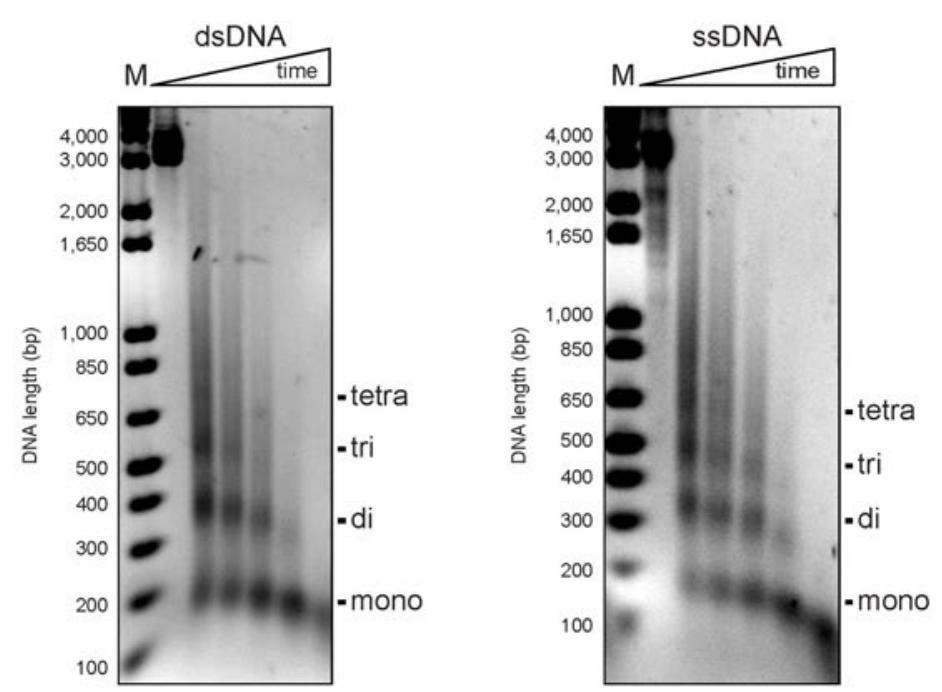

Figure 3.4 | Replication-coupled and replication-independent chromatin assembly results in topological comparable chromatin. (A) Supercoiling assay of $p B S-G_{5} M L$ dsDNA or ssDNA assembled into chromatin in HSE. Extract-induced second strand synthesis (ssDNA) and supercoiling of plasmid DNA were monitored over $4 \mathrm{~h}$. Topoisomers were extracted and visualized after agarose gel electrophoresis by ethidium bromide incorporation. Positions of the supercoiled (multiple circles) and the nicked or closed relaxed forms (closed/open circle) are indicated . (B) MNase digest of assemblies described under A. pBS-G 5 ML chromatin $(300 \mathrm{ng})$ was treated with $25 \mathrm{U}$ MNase for either $0 \mathrm{~s}, 30 \mathrm{~s}$, $45 \mathrm{~s}, 90 \mathrm{~s}, 5 \mathrm{~min}$ or $30 \mathrm{~min}$. DNA fragments were extracted and analyzed on an agarose gel (ethidium bromide stained). The positions of DNA fragments corresponding to mono-, di-, tri- and tetranucleosomal structures are indicated (lane M - DNA size standard).

I wondered whether the relatively fast kinetics detected for the single-stranded pBS$\mathrm{G}_{5} \mathrm{ML}$ template in the supercoiling assay were comparable to those of other ssDNA 
templates. I therefore compared the incorporation of $\left[\alpha-{ }^{32} \mathrm{P}\right]$ dATP into ss $p B S-\mathrm{G}_{5} \mathrm{ML}$ and ss M13 DNA (purchased from New England Biolabs). As shown in Figure 3.5A $\left[\alpha-{ }^{32} \mathrm{P}\right]$ dATP was only incorporated into the single-stranded but not the doublestranded version of each template. The second strand synthesis was blocked by aphidicolin $(100 \mu \mathrm{g} / \mathrm{ml})$ an inhibitor of DNA polymerase $\zeta$. This enzyme is thought to catalyze lagging strand synthesis during DNA replication. A time course revealed that incorporation of $\left[\alpha-{ }^{32} \mathrm{P}\right]$ dATP increases linearly from $0-120 \mathrm{~min}$ (Figure 3.5B). Thereafter, no further radioactivity was incorporated, which confirmed the end of DNA-synthesis after $2 \mathrm{~h}$. The incorporation of radioactive deoxyribonucleotides hence supported the observations made in the topology assays.

A

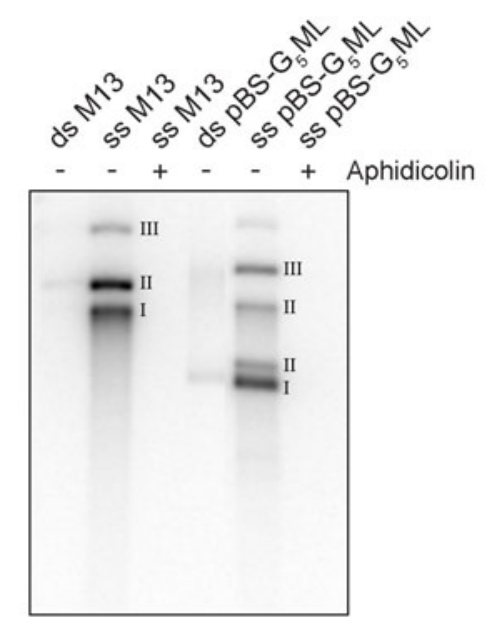

B

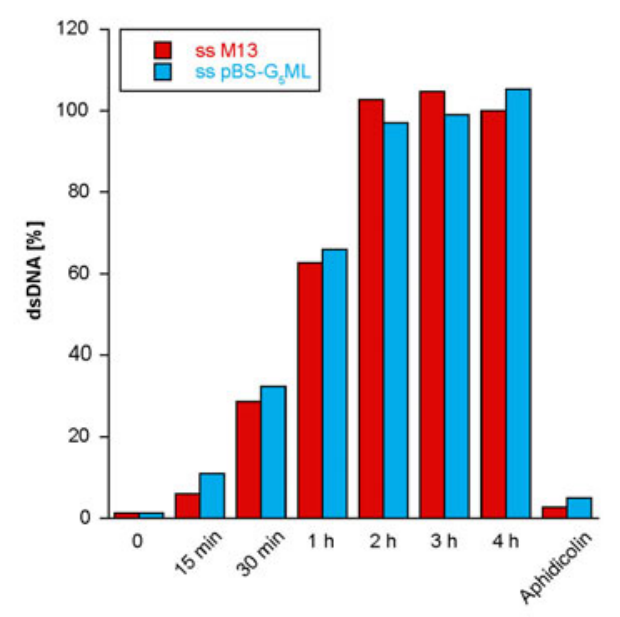

Figure 3.5 | Replication-coupled chromatin assembly visualized by incorporation of $\left[\alpha-{ }^{32} \mathrm{P}\right] \mathrm{dATP}$. (A) Incorporation of $\left[\alpha_{-}{ }^{32} \mathrm{P}\right]$ dATP into double-stranded (ds) and single-stranded (ss) M13 or pBS$\mathrm{G}_{5} \mathrm{ML}$ after $4 \mathrm{~h}$ of assembly is shown. DNA was extracted after assembly and reactions were separated by agarose gel electrophoresis. Individual DNA species were visualized by autoradiography. Indicated on the autoradiogram are positions of supercoiled DNA (I), intermediate topoisomers (II) and relaxed or nicked (III) DNA molecules. (B) Liquid scintillation counting of DNA extracted from chromatin assembled on ssDNA (M13/pBS-G $\left.{ }_{5} \mathrm{ML}\right)$ in HSE in presence of $\left[\alpha-{ }^{32} \mathrm{P}\right]$ dATP $( \pm 100 \mu \mathrm{g} / \mathrm{ml}$ aphidicolin). Incorporation at increasing time points is plotted after normalization against $\left[\alpha-{ }^{32} \mathrm{P}\right] \mathrm{dATP}$ incorporation into ssM13 at $4 \mathrm{~h}(=100 \% \mathrm{dsDNA})$.

Overall, chromatin derived from dsDNA and ssDNA seemed to be saturated to a comparable degree with nucleosomes since the degree of supercoiling was the same at the endpoint of assembly and equal amounts of histone proteins were retrieved upon precipitation with divalent cations. MNase digest of both species suggested that differences in protection of linker DNA exist, with ssDNA-derived chromatin being less well protected. The RC assembly on ssDNA proved to be faster than the RI 
assembly on dsDNA. This observation was not dependent on the DNA sequence as the experiments with single-stranded M13 DNA and double-stranded pUC19 DNA (Figure 3.1B) showed equivalent kinetics.

\subsubsection{Different hydrodynamic behavior of chromatin species}

To further compare the overall structure of the derived chromatin species I analyzed the hydrodynamic behavior of both chromatin samples and naked dsDNA. The samples were loaded onto a linear $10-40 \%[\mathrm{w} / \mathrm{v}]$ sucrose gradient and centrifuged. After centrifugation the gradient was fractionated manually from top to bottom and the chromatin was deproteinized and analyzed by agarose gel electrophoresis. Deproteinization was preceded by an RNase A digest step because the high amounts of RNA present in the extract impaired the DNA signal (data not shown). The assignment of chromatin containing fractions was based on presence of DNA after running deproteinized fractions on an agarose gel. Gel electrophoresis revealed that both chromatin samples sedimented at higher sucrose concentrations in the gradient than naked dsDNA (Figure 3.6A). This was expected as the accessory proteins (e.g. histones) found on chromatin lead to a higher mass and density compared to naked dsDNA. Svedberg values were not determined due to lack of appropriate standard molecules. Even though the topological assays had indicated a comparable topology and thus structure, the chromatin derived from dsDNA surprisingly showed a higher density than chromatin from ssDNA. The peaks of both chromatin species were reproducibly shifted by 1-2 fractions.

These results were confirmed by incorporation of ethidium bromide into nondeproteinized chromatin samples (Figure 3.6B/C). The amount of ethidium bromide incorporation was about 8-10 times higher in naked DNA compared to chromatin where most binding sites are not accessible due to DNA packaging into nucleosomal structures (Figure 3.6B; [168]). However, incorporation into both chromatin samples was also not equal. Incorporation of ethidium bromide into ssDNA-derived chromatin resulted in ca. $25-30 \%$ less fluorescence intensity than observed for chromatin derived from dsDNA even though the same amounts of DNA were used in each assembly reaction and loaded onto the gradient. Agarose gel electrophoresis also confirmed that comparable amounts of DNA were present in the gradient. (Figure 3.6C). 
The observations made in the topological assays and the sucrose gradient sedimentation profiles suggested that there are structural differences existing between chromatin derived from RC and RI assembly pathways. To actually image the chromatin molecules I used atomic force microscopy.

A

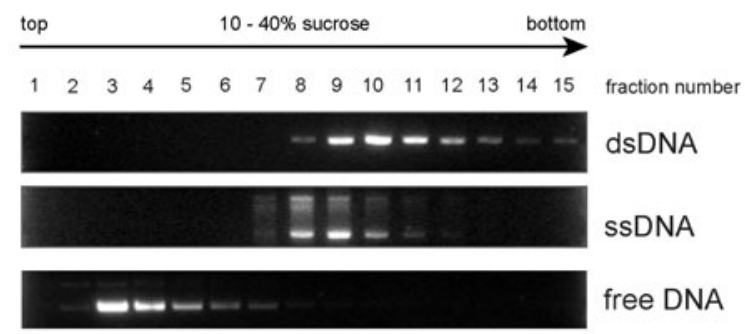

B

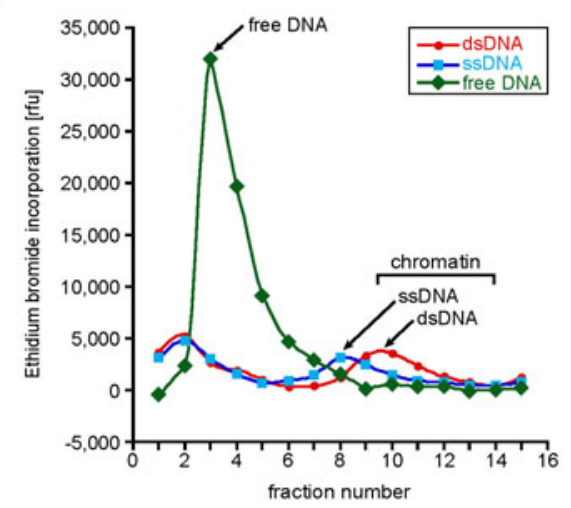

C

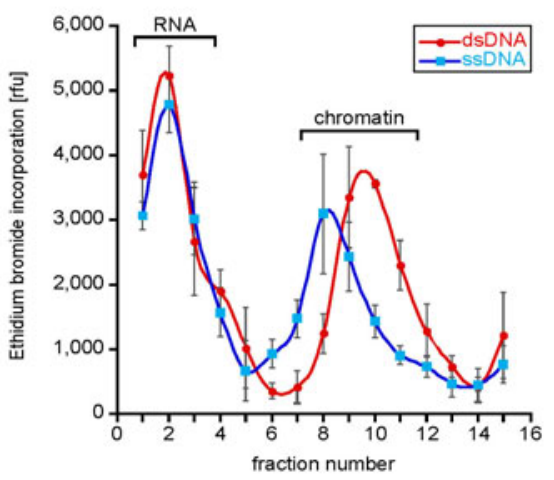

Figure 3.6 | DNA and Chromatin species differ in their hydrodynamic behavior and EtBr incorporation. (A) Chromatin assembly reactions or free dsDNA (2.5 $\mu \mathrm{g}$ total DNA per sample) were separated on a 10-40\% sucrose density gradient and fractionated (fraction volume: $150 \mu 1$ ). $10 \%$ of each fraction was analyzed on an agarose gel (ethidium bromide stained). The free DNA sample was directly loaded onto the gel whereas chromatin samples were first treated with RNase A and deproteinized before electrophoresis. (B) Gradient fractions with free DNA or chromatin (only RNase A treated) were mixed with $0.5 \mu \mathrm{g} / \mathrm{ml}$ ethidium bromide (EtBr) and fluorescence emission of intercalated EtBr was measured at $615 \mathrm{~nm}$ (excitation: $355 \mathrm{~nm}$ ). Relative fluorescence units (rfu) were plotted against gradient fractions. Peaks corresponding to either free DNA or chromatin derived from dsDNA or ssDNA are marked. (C) Graph showing EtBr incorporation of chromatin as in B. Mean values of three independent experiments are shown and RNA/nucleotides and chromatin peaks are labeled.

\subsubsection{RC and RI assembled chromatin species form discrete structures}

Using atomic force microscopy (AFM) I visualized both chromatin species at the endpoint of assembly. Therefore, chromatin was first purified on sucrose density gradients to remove unbound proteins and then fixed with glutaraldehyde. The AFM images revealed that dsDNA-derived chromatin formed rod-like structures whereas the ssDNA-derived chromatin structures were rather spherical and showed a tendency 
to aggregate (Figure 3.7A). Another observation from the images was that single nucleosomes were not distinguishable due to the dense packaging of both species and presumably attachment of other proteins.

A
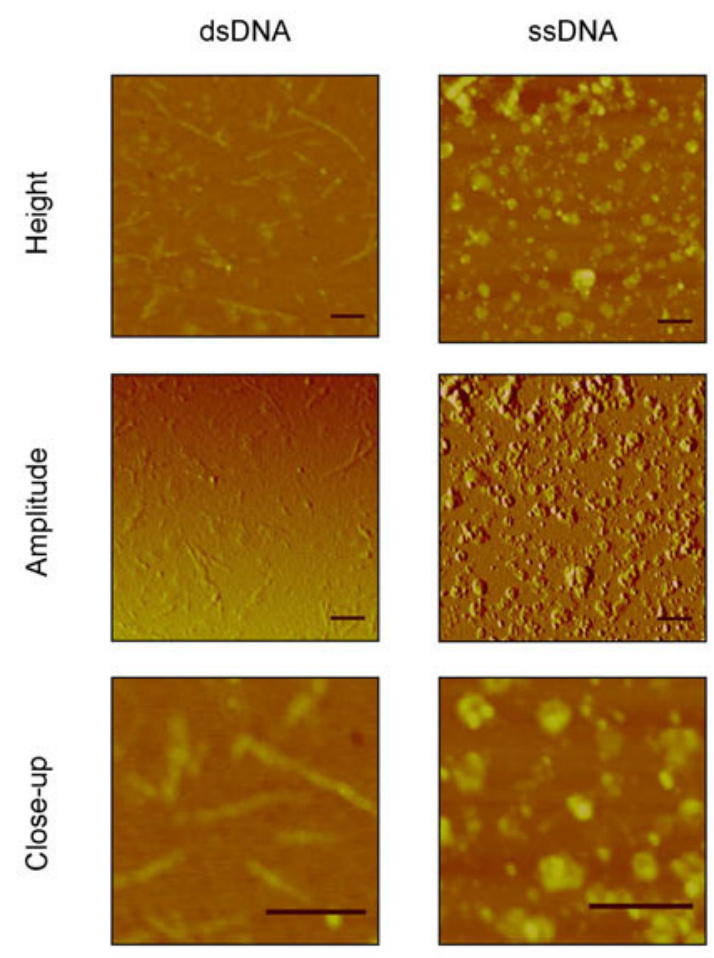

B

dsDNA

ssDNA
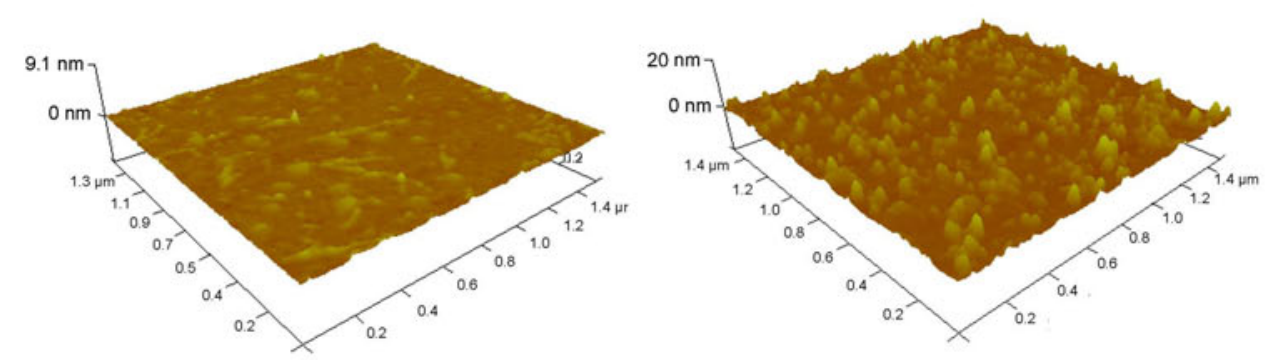

Figure 3.7 | AFM analysis of chromatin species. (A) Chromatin assemblies were purified via sucrose gradient sedimentation, dialyzed and cross-linked with glutaraldehyde (see material\&methods for details). AFM images were taken of cross-linked material spotted on mica. Two representations (height and amplitude) as well as a close-up of the top panel are shown. Higher intensities (bright yellow) reflect an increase in height or amplitude. Scale bar corresponds to $200 \mathrm{~nm}$ in all images. (B) 3D landscape representation of dsDNA/chromatin and ssDNA/chromatin of top panel shown in A. Maximal heights are indicated on the z-axis.

Generally, the diameter of a single nucleosomes is about $11 \mathrm{~nm}$ [5]. The average width of dsDNA/chromatin fibers was $21 \mathrm{~nm}( \pm 2.4 \mathrm{~nm}, \mathrm{n}=23)$ whereas their lengths 
corresponded to about $115 \mathrm{~nm}( \pm 21.4 \mathrm{~nm}, \mathrm{n}=23)$. The average diameter of the spherical ssDNA/chromatin structures was about $60 \mathrm{~nm}( \pm 7.3 \mathrm{~nm}, \mathrm{n}=25)$. The heights of both species varied as well, with the dsDNA/chromatin fibers reaching a maximum of $10 \mathrm{~nm}$ and ssDNA/chromatin forming complexes of up to $20 \mathrm{~nm}$ in height (Figure 3.7B).

While both structures clearly differed from each other, the structures observed in AFM did not fully explain the shift of dsDNA to higher sucrose concentration in the hydrodynamic assays. Generally, one assumes that rod-like particles migrate slower than spherical particles of the same molecular weight due to a higher friction coefficient. This led to two explanations. Either more (non-histone) proteins are associated with the dsDNA/chromatin than with ssDNA/chromatin or the observed structures in AFM were due to unpredictable changes introduced by the fixation procedure. To actually determine the true conformation of both chromatin species, more experiments with varying fixation procedures are necessary.

\subsection{Biochemical characterization of chromatin}

\subsubsection{Identification of chromatin-associated proteins}

Next, I sought to determine whether the observed structural differences are reflected by the presence of specific proteins in the two chromatin samples. To this end, I analyzed the proteins associated with $\mathrm{MnCl}_{2}$-precipitated chromatin samples by mass spectrometry in close collaboration with the group of Henning Urlaub (Max Planck Insitute for biophysical chemistry, Göttingen). Proteins were extracted from gels after an in-gel trypsin digest and subjected to LC-coupled mass spectrometry. In total more than 1,200 proteins were identified. The Mascot results were analyzed by subtracting mock control from each sample and then extracting proteins present in both samples and proteins only present in either dsDNA or ssDNA-derived chromatin (Figure 3.8). This subtraction analysis was based on the gi-numbers assigned to the spectra. However, due to the tetraploid genome of $X$. laevis and an incomplete genome database there was still redundancy in the calculated tables. Where possible these redundancies were removed manually (see appendix for complete list of proteins). The manual removal was based on similarity searches (BLAST www.ncbi.nlm.nih.gov/blast/) of hits carrying different gi-numbers but identical 
protein names. In general, there were fewer unique proteins identified for the ssDNA sample (25 proteins) compared to proteins present in both (65 proteins) or only the dsDNA-derived chromatin (91 proteins).

I filtered the retrieved data for proteins that had already been described to be associated with chromatin metabolism and gene regulation and grouped them into four categories. This excerpt of proteins is presented in Figure 3.8B and I will briefly outline their general functions in chromatin metabolism and if known in the individual chromatin assembly pathways.

A

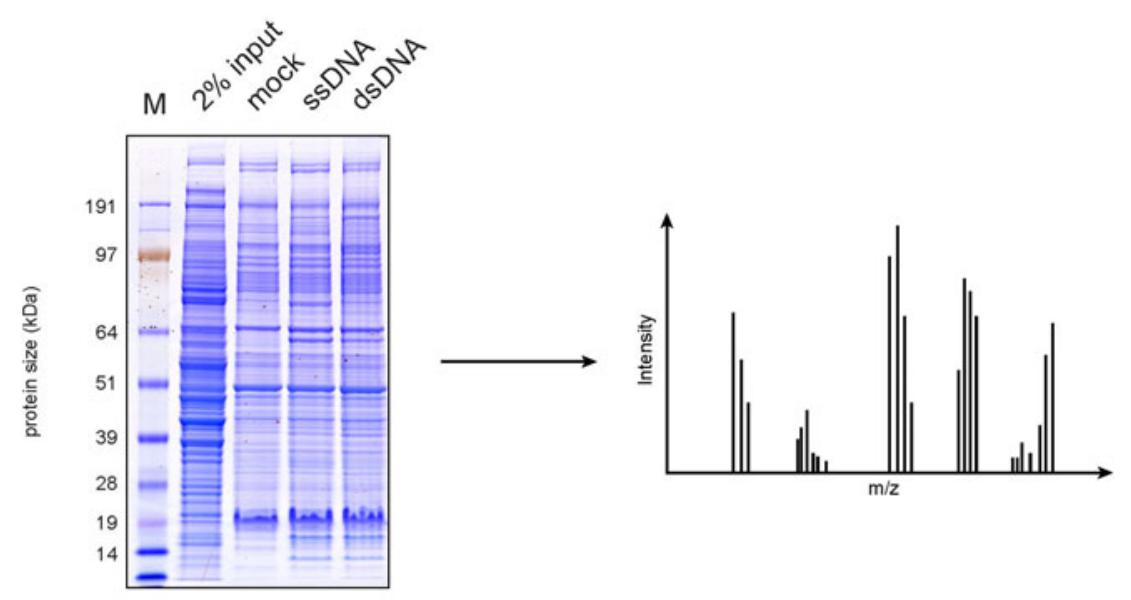

B
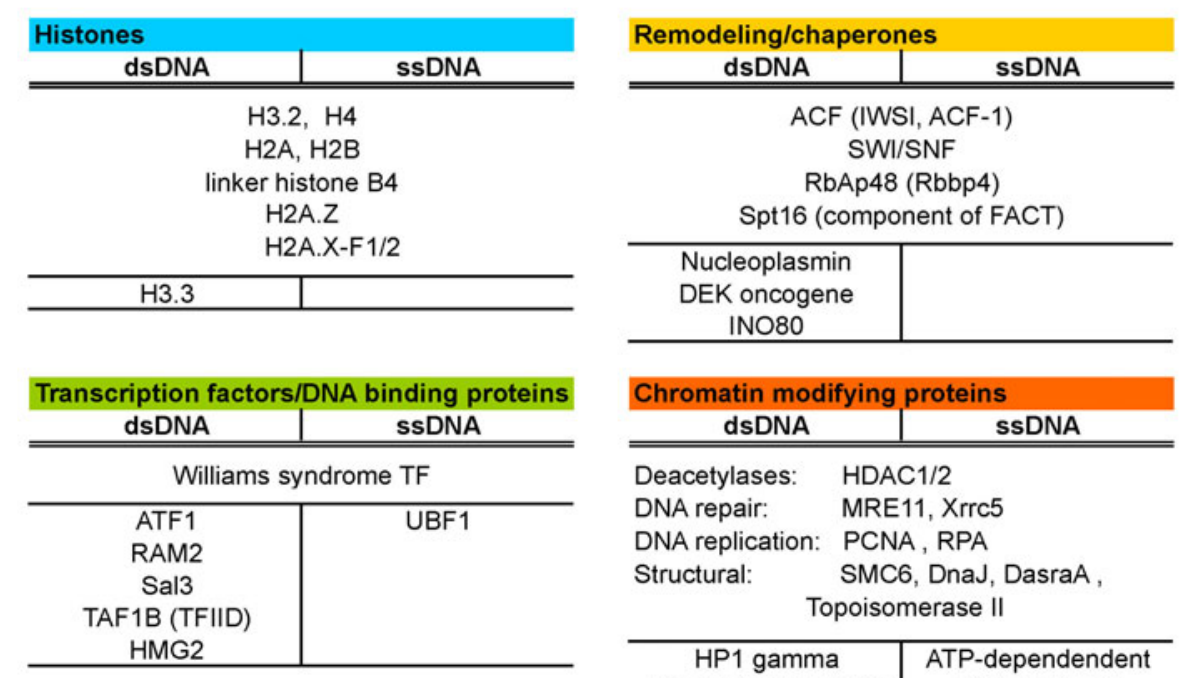

\begin{tabular}{|c|c|}
\hline \multicolumn{2}{|c|}{ Chromatin modifying proteins } \\
\hline dsDNA & ssDNA \\
\hline $\begin{array}{lr}\text { Deacetylases: } & \text { HDA } \\
\text { DNA repair: } & \text { MRE } \\
\text { DNA replication: } & \text { PCN } \\
\text { Structural: } & \text { SMC } \\
& \text { Topoisor }\end{array}$ & $\begin{array}{l}1 / 2 \\
1, \text { Xrrc5 } \\
\text {, RPA } \\
\text { DnaJ, DasraA, } \\
\text { lerase II }\end{array}$ \\
\hline $\begin{array}{c}\text { HP1 gamma } \\
\text { PR-SET7 like protein } \\
\text { NuRD complex } \\
\text { (Mi-2/MTA1) }\end{array}$ & $\begin{array}{c}\text { ATP-dependendent } \\
\text { DNA helicase } \\
\text { DNA ligase }\end{array}$ \\
\hline
\end{tabular}

Figure 3.8 | Mass spectrometry analysis of chromatin associated proteins. (A) Coomassie-stained gel with precipitated chromatin samples (M-molecular size standard). The gel was cut into pieces and analyzed by LC-coupled tandem mass spectrometry after an in-gel digest with trypsin. (B) Tables show an excerpt of chromatin-associated proteins found in either dsDNA or ssDNA-derived chromatin or in both samples (after subtraction of proteins present in mock control based on identical gi numbers). 


\subsubsection{Histone proteins}

I was able to identify all core histone proteins $\mathrm{H} 3$ (H3.2), H2A, H2B and H4 in both samples as well as the maternal linker histone variant B4 (Figure 3.8B upper left panel). Interestingly, a high mobility group protein (HMG2) was found only in the dsDNA sample. This protein nonspecifically binds DNA and can replace linker histones in chromatin [169]. Besides the canonical histone proteins, the H2A histone variants H2A.Z and H2A.X-F1/2 were detected in both samples whereas the H3 variant H3.3 was only found in the RI dependent assembly pathway (dsDNA sample). The latter observation is in agreement with other studies $[16,20]$.

\subsubsection{Transcription factors/DNA binding proteins}

A variety of transcription factors was identified in both assembly pathways (Figure 3.8B lower left panel). Present in both samples was Williams transcription factor, however, TAF1B (part of TFIID), ATF1, RAM2 and Sal3 were only found in the dsDNA sample and UBF1 solely in the ssDNA sample. All of these proteins represent rather general transcription factors.

\subsubsection{Remodeling complexes and histone chaperones}

Assembly of chromatin structures requires remodeling complexes and histone binding and transfer proteins named chaperones. Very few of them are known to exclusively associate with only one assembly pathway. As expected remodeling factors and chaperones thus appeared in both pathways like the ACF subunits ISWI and Acf1, the SWI/SNF complex and the Rbbp4 (RbAp48) chaperone (Figure 3.8B upper right panel). Rbbp4 is a H3-H4 histone chaperones and often found as subunits of larger complexes. It can target chromatin assembly factors, chromatin remodeling factors and histone deacetylase complexes to chromatin through its affinity to histones [170]. Rbbp4 is a multifunctional chaperone and amongst others constitutes a subunit of CAF-1 (Chromatin assembly factor 1). CAF-1 is the key player involved in RC assembly and DNA repair $[20,81,171]$.

Interestingly, Spt16 the chaperone subunit of FACT (facilitates chromatin transcription) was identified as component of both chromatin species. FACT itself is known to promote transcription by eviction of $\mathrm{H} 2 \mathrm{~A}-\mathrm{H} 2 \mathrm{~B}$ through chromatin 
templates, a process independent of DNA synthesis [172-174]. However, recent studies suggested that it might also function during replication [111]. In particular, a homologues FACT complex was identified in Xenopus oocytes before as DUF (DNA unwinding factor) that proved essential for DNA replication in egg extracts [175].

Three proteins were restricted to the RI assembly pathways on dsDNA: Nucleoplasmin, INO80 and the DEK oncogene. Nucleoplasmin, an H2A-H2B chaperone, is a highly acidic phosphoprotein that is essential for sperm decondensation in $X$. laevis eggs $[122,176]$. The function of Arp8, a subunit of INO80 remodeling complex, is largely unknown. INO80 is implied in various pathways like transcriptional regulation, DNA repair and DNA replication and might interact with H2A.X and H2A.Z [177]. The DEK oncogene was identified very recently to be a $\mathrm{H} 3.3$ specific histone chaperone specifically depositing H3.3/H4 tetramers at transcriptionally active regions [119]. It might hence be responsible for the detected H3.3 in the dsDNA/chromatin sample.

\subsubsection{Chromatin modifying enzymes}

In addition, I searched the data for chromatin/histone modifying enzymes or proteins with a general implication in chromatin metabolism (Figure 3.8B lower right panel). These proteins are potential candidates to modulate nucleosomal interactions, which in turn lead to functional different chromatin structures. In both samples histone deacetylases 1 and 2 (HDAC1/2) were detected that belong to Class I HDACs that are inhibited by sodium butyrate. The identification of certain chaperones (Rbbp4) and HDACs suggests that the nucleosome remodeling histone deacetylase complex (NuRD) associates with the analyzed chromatin species. Such a Mi-2 HDAC complex has been characterized before in the egg extracts [178]. The only putative histone methyltransferase identified was a PR-Set7-like protein in the dsDNA sample. PRSet7 (or SETD8) is so far the only known SET domain containing protein that monomethylates lysine 20 on histone H4 (H4K20me1) [36]. Furthermore, I identified HP1 gamma (Heterochromatin protein 1), an HP1 isoform that localizes to both euchromatic and heterochromatic regions of the genome [179]. This protein was also exclusively found in the RI assembly pathways.

Other proteins involved in structural maintenance of chromosomes (SMC6, DnaJ, DasraA) or in DNA repair (MRE11, XRRC5) were found along with DNA replication 
proteins like PCNA and the ssDNA-binding protein RPA in both samples (Figure 3.8B lower right panel).

The proteome analyses of both chromatin species revealed that distinct sets of proteins were associated with each pathway besides a set of common factors. The common factors mainly included canonical histone proteins, histone chaperones, remodeling complexes, structural maintenance proteins and histone deacetylases (HDACs). However, each chromatin species also 'attracted' specific factors that could potentially influence chromatin structure by e.g. methylating histone proteins (PRSet7), deposition of histone variants (H3.3, DEK oncogene) or initiation of transcription (see set of transcription factors). This observation implied that assembly

pathways are directly involved in recruiting factors and thereby potentially mediate downstream effects.

Interestingly, the histone variant H3.3 was exclusively incorporated into the dsDNAderived chromatin, which also contained a H3.3 specific chaperone (DEK). On the contrary, the H2A variant H2A.Z was found in both chromatin assembly pathways. Besides the DEK oncogene, H3.3 was shown to associate with HIRA, a chaperone that involved in RI assembly [20, 124]. However, it is not clear from the literature whether the RI assembly pathway only mediates incorporation of the H3.3 variant or whether canonical $\mathrm{H} 3$ is also incorporated. The mass spectrometry data analysis suggested that both species were present in RI assembly. I decided to further confirm the observations made on the H3.2, H3.3 and the H2A.Z histones.

\subsubsection{Histone variants are not equally distributed - Incorporation of $\mathbf{H} 3.3$ and H2A.Z}

H3.3 was identified in the described mass spectrometry analysis with a high score and sequence coverage (Figure 3.9A). It is highly conserved among different species and differs in $X$. laevis from the canonical H3.2 variant by only 5 amino acids (Figure 3.9B). I repeated the mass spectrometry analysis on sucrose gradient-purified chromatin to exclude that co-precipitation of non-chromatinized histone proteins had influenced the previous analysis. 
A

H3 histone, family $3 \mathrm{~A}$ (H3.3)

1 MARTKQTARK STGGKAPRKQ LATKAARKSA PSTGGVKKPH RYRPGTVALR

51 EIRRYQKSTE LLIRKLPFQR LVREIAQDFK TDLRFQSAAI GALQEASEAY

101 LVGLFEDTNL CAIHAKRVTI MPKDIQLARR IRGERA

$69 \%$ sequence coverage, 12 peptides identified (Score 647)

B

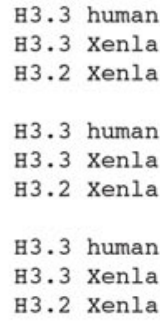

C

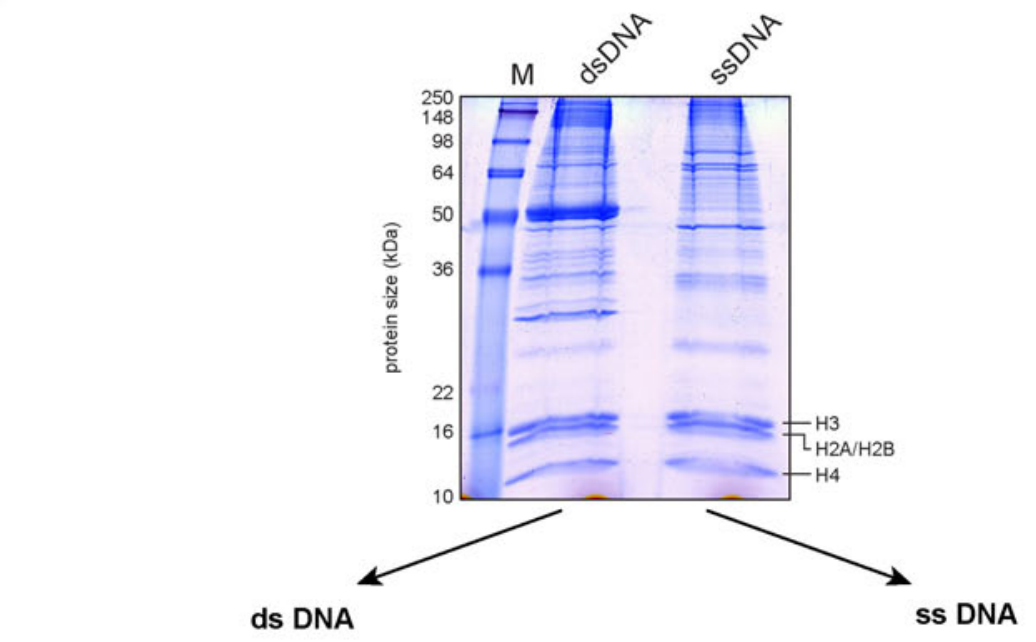

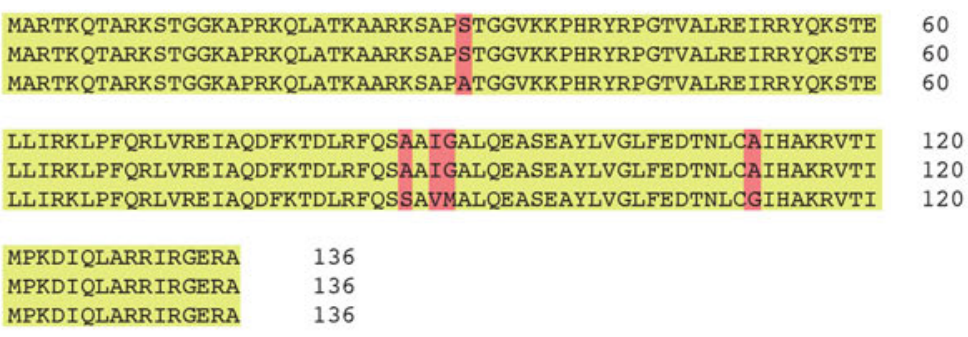

MPKDIQLARRIRGERA 136

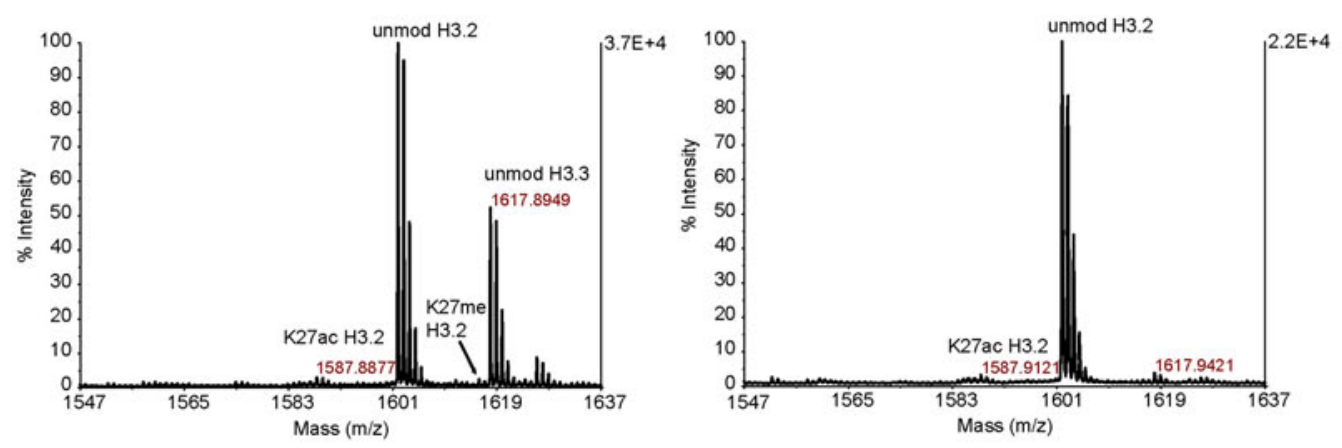

Figure 3.9 | Mass spectrometry reveals incorporation of H3.3 into RI assembled chromatin. (A) Protein sequence of X. laevis H3.3 (UniProt ID: Q6PI79) identified in chromatin assembled on dsDNA. Peptides identified by mass spectrometry are labeled in red and H3.3 specific peptides are underlined. (B) Alignment of H3.3 protein sequences from human (UniProt ID: P84243) and X. laevis [Xenla] in comparison to the canonical H3 variant, H3.2, of X. laevis (UniProt ID: P84233). Differences in amino acid composition are highlighted in red. (C) Chromatin derived from dsDNA and ssDNA was assembled in HSE, purified by sucrose gradient sedimentation and chromatin-containing fractions were precipitated. Top: The precipitates were separated by SDS-PAGE (Coomassie-stained gel, M-molecular size standard). Individual histone lanes were cut out and analyzed by mass spectrometry. Bottom: Spectra of histone H3 are shown and analyzed for presence of canonical H3.2 and replication-dependent variant $\mathrm{H} 3.3$. 
The results of the repeated mass spectrometry analysis nicely confirmed that $\mathrm{H} 3.3$ as well as the conventional $\mathrm{H} 3.2$ are incorporated into dsDNA/chromatin. In the ssDNA/chromatin sample only the canonical H3.2 was assigned to the spectrum (Figure 3.9C). As judged from the intensities observed for H3.3 and H3.2 specific peptides it appears that $\mathrm{H} 3.3$ is not the major $\mathrm{H} 3$ histone incorporated during RI assembly.

Next, I wanted to verify the presence of the H3.3 and H2A.Z variants found by mass spectrometry in the assembled chromatin species by an orthogonal strategy. The described links between RI assembly (HIRA) and H3.3 incorporation have been derived indirectly from immunoprecipitation experiments of ectopically tagged histone proteins (H3.3 and H3.1) that led to co-precipitation of HIRA [20]). I wanted to test whether H3.3 is actively incorporated during an RI assembly process but not during RC assembly as the mass spectrometry data suggested.

To investigate whether H3.3 is exclusively incorporated during RI assembly I set-up chromatin assemblies in presence of exogenous H3.3. I expressed recombinant H3.3 with an N-terminal His ${ }_{6}$-tag (Figure 3.10C). The tag and the resulting size shift facilitated the analyses since antibodies specifically recognizing $\mathrm{H} 3.3$ but not $\mathrm{H} 3.2$ are not available [124]. First, exogenous $\mathrm{His}_{6}-\mathrm{H} 3.3$ histone was added to the assembly and the chromatin analyzed for H3.3 incorporation. Here, I did not observe a preferential incorporation of histone His $_{6}-\mathrm{H} 3.3$ into dsDNA-derived chromatin but detected His $_{6}-\mathrm{H} 3.3$ in both species (Figure 3.10C). Titration experiments revealed that this 'incorporation' rather represents an unspecific binding of the histone to chromatin/nucleic acids (data not shown).

Considering that $\mathrm{H} 3$ and $\mathrm{H} 4$ are usually bound in solution by chaperones as heterodimeric $[20,101]$ or tetrameric structures $[64,180]$, I prepared tetramers consisting of $\mathrm{His}_{6}-\mathrm{H} 3.3$ and $\mathrm{H} 4,\left[\mathrm{His}_{6}-\mathrm{H} 3.3 / \mathrm{H}_{4}\right]_{2}$, by salt dialysis (Figure $3.10 \mathrm{E}$ ). Upon addition of tetramers to the extract assembly I indeed detected specific incorporation of H3.3 in dsDNA/chromatin (Figure 3.10F).

The amount of incorporated H3.3 was overall less than expected. The extract system proved very sensitive to high amounts of $[\mathrm{H} 3.3 / \mathrm{H} 4]_{2}$ tetramers leading to incomplete assembly and precipitation (data not shown). Presumably the excess of histones/tetramers over chaperones leads to impairment of the assembly process. 
A

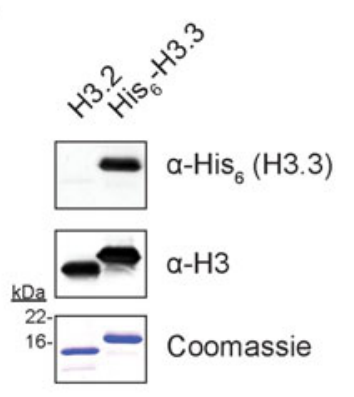

C

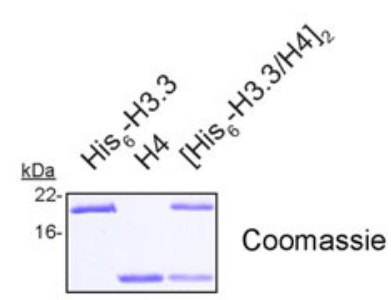

B

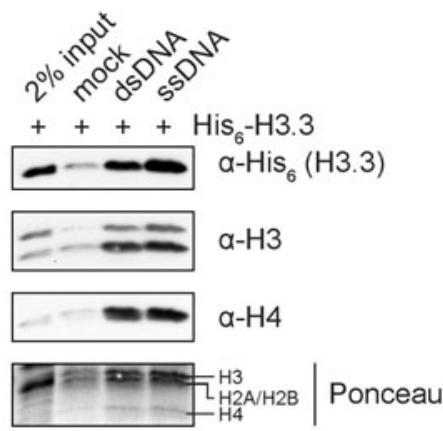

D

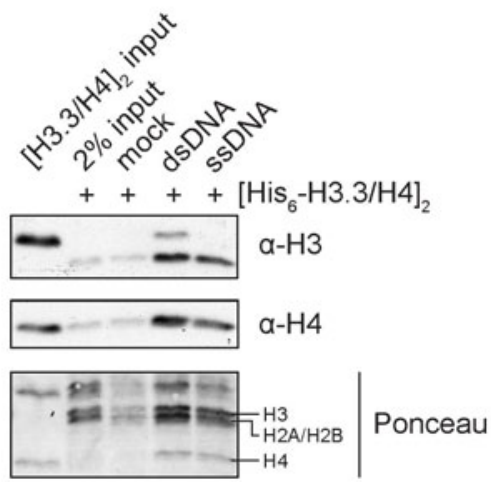

Figure 3.10 | Histone variant $\mathrm{H3.3}$ is specifically incorporated in a replication-independent fashion.

(A) Recombinant H3.2 and His-tagged H3.3 were analyzed on Coomassie-stained SDS-PAGE gel and by Western blot (anti-His, anti-H3 antibodies). (B) Incorporation of $\mathrm{His}_{6}-\mathrm{H} 3.3$ during chromatin assembly was tested by addition of $0.5 \mu \mathrm{g}$ single $\mathrm{His}_{6}-\mathrm{H} 3.3$ histone to each assembly reaction. Chromatin was precipitated and analyzed in Western blots with anti-His, anti-H3 and anti-H4 antibodies. (C) $1 \mu \mathrm{g}$ of $\mathrm{His}_{6}-\mathrm{H} 3.3, \mathrm{H} 4$ and $\left[\mathrm{His}_{6}-\mathrm{H} 3.3 / \mathrm{H} 4\right]_{2}$ tetramers were separated on a SDS-PAGE gel and stained with Coomassie Brilliant Blue. (D) $\left[\mathrm{His}_{6}-\mathrm{H} 3.3 / \mathrm{H} 4\right]_{2}$ tetrameric complexes $(1 \mu \mathrm{g})$ were added to indicated assembly reactions. Chromatin was precipitated and incorporation of tetramers was analyzed by immunoblotting against $\mathrm{H} 3$. Immunodetection with anti-H4 antibodies as well as Ponceau staining of the membrane served as loading control. Input of $\left[\mathrm{His}_{6}-\mathrm{H} 3.3 / \mathrm{H} 4\right]_{2}$ was $1 \mu \mathrm{g}$.

A study in Drosophila also demonstrated that, when expressed during S-phase, H3.3 is incorporated during RC assembly [16]. The opposite phenomenon, an incorporation of the major $\mathrm{H} 3$ histone outside of S-phase, was not detected. The add-on experiments and mass spectrometry analysis, however, suggested that H3.3 is preferentially incorporated into dsDNA in the Xenopus egg extract system, but it is not the only H3 variant present in chromatin derived from RC assembly. 
In contrast to H3.3 I detected H2A.Z in both assembly pathways by mass spectrometry (Figure 3.8B, Figure 3.11A). H2A.Z is an essential H2A variant and like all histone variants also synthesized outside of S-phase [181]. It is widely distributed throughout the genome and implicated in transcriptional control. Recently, nucleosomes bearing H3.3 and H2A.Z have been shown to decrease nucleosome stability and to occupy promoter regions $[21,182,183]$.

I analyzed precipitated chromatin by Western blot for endogenous H2A.Z with specific H2A.Z antibodies. Thereby, I could confirm the observations from the mass spectrometry analyses (Figure 3.11). Both chromatin species contained H2A.Z, which consequentially must be incorporated during RI and RC assembly.

A

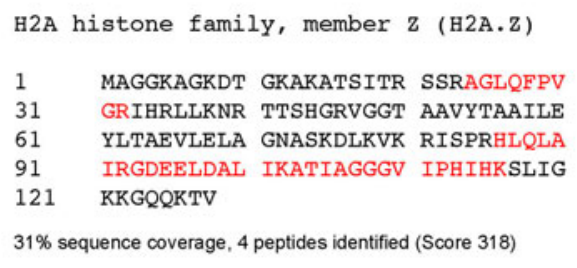

B

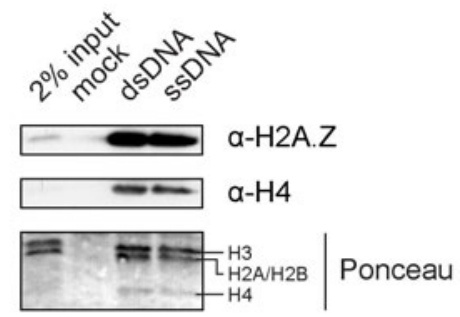

Figure 3.11 | H2A.Z associates with both chromatin assembly pathways. (A) Protein sequence of $X$. laevis H2A.Z (UniProt ID: P70094) identified in chromatin assembled on dsDNA and ssDNA (mockno DNA). Peptides identified by mass spectrometry are labeled in red. (B) Western blot of precipitated chromatin assemblies against histone variant H2A.Z (anti-H2A.Z antibodies). Anti-H4 antibodies and Ponceau staining of the membrane served as loading control.

H2A.Z has not been described so far as a replication-dependent histone. Mass spectrometry and Western blot analyses, however, strongly argue for incorporation of this $\mathrm{H} 2 \mathrm{~A}$ variant during $\mathrm{RC}$ and $\mathrm{RI}$ assembly. A specific H2A.Z remodeling complex that replaces H2A.Z at promoter sites has been described [70, 184-186]. On the contrary, unincorporated H2A.Z was shown to be bound by NAP-1 [185, 186], a histone chaperone usually complexing conventional $\mathrm{H} 2 \mathrm{~A}-\mathrm{H} 2 \mathrm{~B}$ dimers. In the mass spectrometry analysis I detected FACT, which facilitates transcription by eviction of H2A-H2B dimers and aids their re-deposition when transcription is finished. However, FACT has only been described to mediate exchange of the H2A variant H2A.X so far [187], which had been identified as well in mass spectrometry analysis. 


\subsubsection{Methylation and acetylation patterns of RI or RC assembled chromatin}

Canonical histones as well as histone variants are subject to posttranslational modifications [32]. Especially, H3.3 has been shown to correlate with actively transcribed genes and carry modifications associated with these loci [115]. The variations in histone variants on both species thus made me wonder whether histone modifications exist on chromatin already as a result of chromatin assembly.

\subsubsection{Methylation patterns}

First, I tested whether global differences in methylation of core histone proteins exist. Chromatin assembly in presence of the radioactive methyl donor ${ }^{3} \mathrm{H}-\mathrm{SAM}$ (SAdenosyl L-methionine) demonstrated a striking difference between both species. While during RI chromatin assembly on dsDNA both H3 and H4 were methylated, hardly any methylation was detected on the ssDNA-derived chromatin (Figure 3.12A). Thereby more methylation occurred on histone $\mathrm{H} 4$ than on $\mathrm{H} 3$ in the dsDNA sample. A recent study showed that H4K20mel is important for chromatin maturation after assembly [153]. Therefore, I performed Western blot analyses of precipitated chromatin using specific antibodies directed against the different methylation states of H4K20 (Figure 3.12B). Immunoblots revealed that indeed H4K20me1 is present on dsDNA/chromatin but not H4K20me2 or H4K20me3. While the latter ones are implicated in transcriptional silencing [42], the role of H4K20me1 remains highly controversial [188-190]. The other possible methylation sites on H4, H4R3 and H4K59 (mainly present in $S$. cerevisiae), were not tested due lack of specific antibodies.

In contrast to $\mathrm{H} 4$, histone $\mathrm{H} 3$ can be extensively methylated on several residues. I focused my attention on generally activating or repressing methyl marks on lysine residues. H3K4me1/2/3 belong to the group of 'active marks' and are mainly found at transcriptional start sites. Furthermore, these modifications were shown to be present on H3.1 and H3.3 histones isolated from Drosophila KC cells [115]. I probed for all three methylation states and could verify their presence on the dsDNA/chromatin (Figure 3.12C). I thus wondered whether other active histone methylation marks were present as a result of RI assembly. Strong correlation between H3K4me and H3K79me2 has been observed in Drosphila [191] another mark associated with 
transcriptionally active regions of the genome. However, I did not observe H3K79me2 in RI or RC assembly with the antibody used in this study. Additionally, I probed against $\mathrm{H} 3 \mathrm{~K} 36 \mathrm{me} 2$. In contrast to $\mathrm{H} 3 \mathrm{~K} 4 \mathrm{me}$, which shows punctuate localization to transcriptional start sites, $\mathrm{H} 3 \mathrm{~K} 36 \mathrm{me} 2$ is found in the body of transcribed genes and is important for transcription elongation [192]. Western blot against H3K36me2 did not show a signal in either assembly pathway (Figure 3.12C).

A

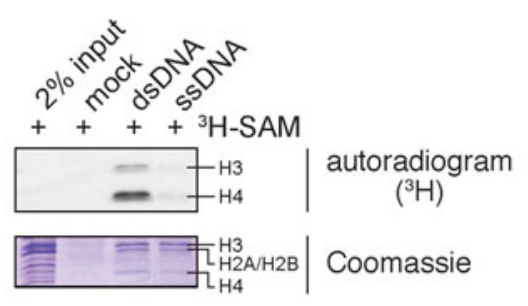

C

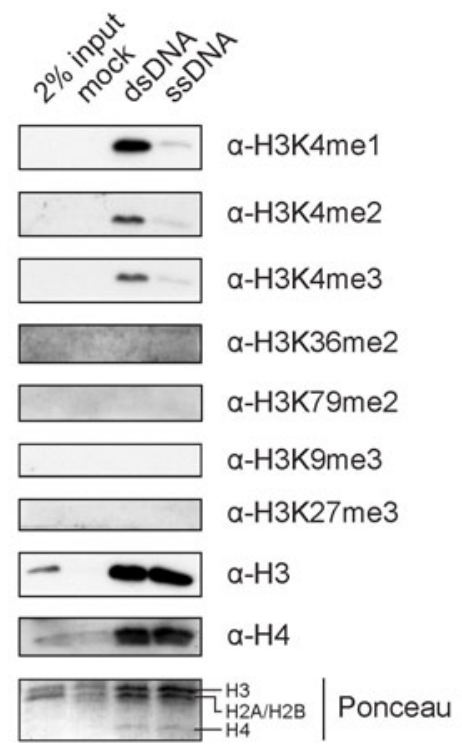

B

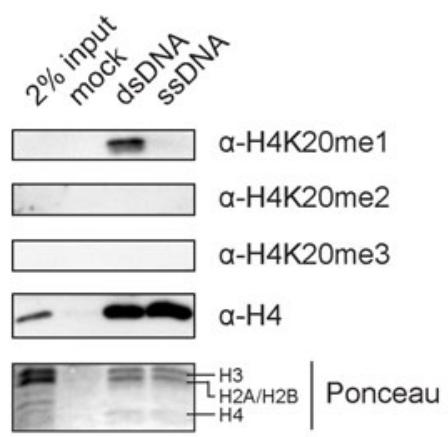

D

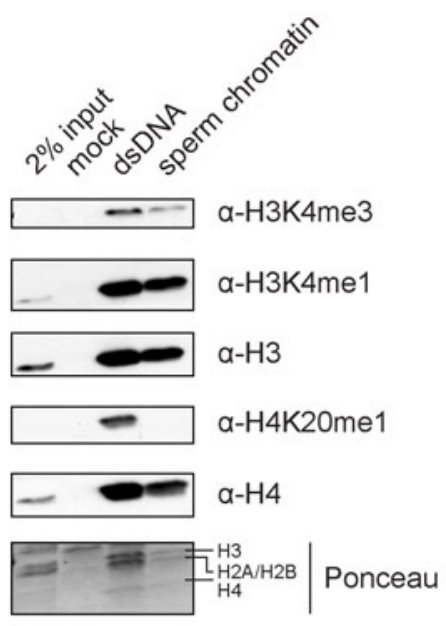

Figure 3.12 | Chromatin assembled independent of replication is enriched in $\mathrm{H3}$ and $\mathrm{H4}$ methylation. (A) Chromatin was assembled on dsDNA or ssDNA (mock-no DNA) in presence of radioactive methyl donor ${ }^{3} \mathrm{H}-\mathrm{SAM}$ (S-[Methyl- $\left.{ }^{3} \mathrm{H}\right]$-Adenosyl-L-methionine), precipitated and analyzed by Coomassie staining and autoradiography. (B) Western blot of precipitated, non-radioactive chromatin assemblies. Membrane was incubated with anti-H4K20me1/me2/me3. Anti-H4 antibodies and Ponceau staining was used to verify equal loading. (C) Analyses of $\mathrm{H} 3$ methylation of extractassembled chromatin. Precipitated chromatin was analyzed with indicated antibodies. Western blots of representative input (anti-H3/anti-H4 antibodies, Ponceau staining) are shown. (D) Demembranated sperm chromatin from $X$. laevis was incubated in HSE for $2 \mathrm{~h}$ at $23^{\circ} \mathrm{C}$, precipitated and analyzed by Western blot with anti-H3K4me1/me3, anti-H3, anti-H4K20me1 and anti-H4 antibodies. 
Despite the presence of activating methyl marks I tested for the repressive histone modifications $\mathrm{H} 3 \mathrm{~K} 9 \mathrm{me} 3$ and $\mathrm{H} 3 \mathrm{~K} 27 \mathrm{me} 3$. Both modifications are considered hallmarks of heterochromatin and silenced chromatin domains. The simultaneous presence of activating and repressive marks in certain genomic regions (called bivalent domains) has so far only been described for pluripotent embryonic stem cells [193]. The egg extract mediated assembly did not introduce any of these modifications as shown in the Western blot analyses against H3K9me3 and H3K27me3 (Figure 3.12C).

\subsubsection{Methylation patterns of decondensed sperm chromatin}

The Xenopus egg is capable of decondensing sperm chromatin. This physiologically relevant process occurs after fertilization and is associated with the exchange of sperm specific DNA binding proteins by histone proteins and occurs independent of DNA synthesis [122, 169, 176]. I wondered whether during decondensation the same methyl marks are incorporated as during RI chromatin assembly on dsDNA. Therefore, demembranated sperm chromatin was incubated in Xenopus HSE under the same conditions used for chromatin assembly reactions. Figure 3.12D shows a Western blot of decondensed sperm chromatin and dsDNA chromatin assembly. I probed the precipiatetd chromatin against $\mathrm{H} 3 \mathrm{~K} 4 \mathrm{me} 1$ and $\mathrm{H} 3 \mathrm{~K} 4 \mathrm{me} 3$ and indeed both marks were present on the sperm chromatin. However, when I probed for H4K20me1 no signal was detected on sperm chromatin in comparison to the dsDNA/chromatin. The lack of H4K20me1 cannot be fully explained at this point. Xenopus sperm still contains H3-H4 but reduced levels of H2A-H2B before decondensation [176]. I thus cannot exclude that presumably little exchange of $\mathrm{H} 4$ histones accounts for the lack of H4K20me1.

\subsubsection{Acetylation patterns}

Acetylation represents another prominent posttranslational modification of histone proteins. I analyzed global $\mathrm{H} 3$ acetylation levels of chromatin with anti-acetyl $\mathrm{H} 3$ antibodies. Immunoblots showed a minor reduction of $\mathrm{H} 3$ acetylation for the RC assembly on ssDNA (Figure 3.13A). Besides the subtle differences in H3 acetylation I observed a strong reduction of global $\mathrm{H} 4$ acetylation levels during $\mathrm{RI}$ assembly on the dsDNA template (Figure 3.13B). 
A

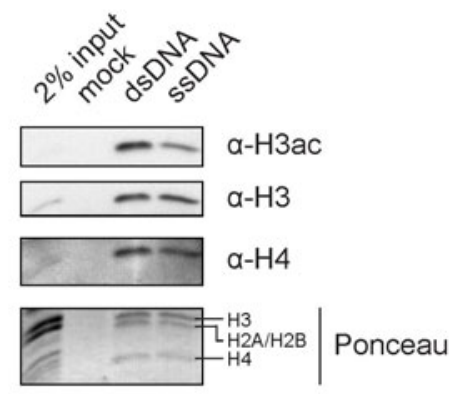

C

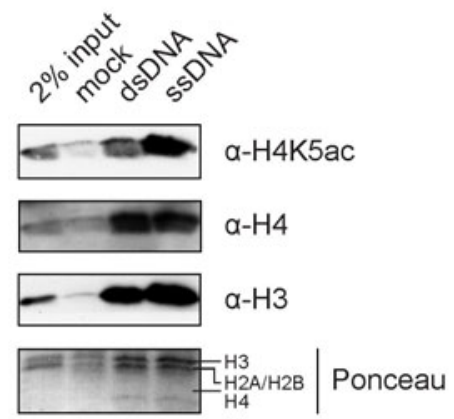

B

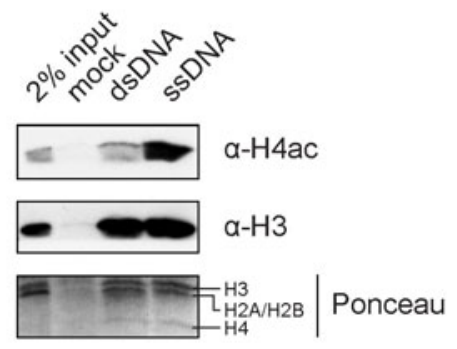

D

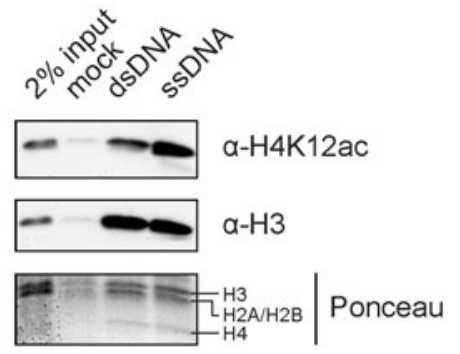

Figure 3.13 | Histone $\mathrm{H} 4$ acetylation patterns change upon chromatin assembly on dsDNA. Chromatin assemblies in HSE were precipitated and analyzed by Western blot. (A) Acetylation of histone $\mathrm{H} 3$ was investigated with anti-H3ac antibodies. Anti-H3/anti-H4 antibodies and Ponceau staining were used to confirm equal loading. (B) Global H4 acetylation levels were analyzed by immunodetection with anti-H4ac antibodies. Acetylation of specific $\mathrm{H} 4$ lysine residues was analyzed with (C) anti-H4K5ac and (D) anti-H4K12ac antibodies in Western blots.

It is known that newly synthesized histones are acetylated in the cytoplasm by HAT1 on $\mathrm{K} 5$ and $\mathrm{K} 12$ of $\mathrm{H} 4$ [47, 99]. This general feature of non-deposited histones is also true for histones stored in Xenopus eggs and oocytes (Figure 3.13B/C/D input lane; [194]. Acetylation marks are removed after histone deposition on DNA by the action of HDAC1/2 [48]. This process appeared to be enhanced in the RI chromatin assembly on dsDNA. The different chromatin species were probed for acetylation of the mentioned residues $\mathrm{K} 5$ and $\mathrm{K} 12$ on H4. Here, I detected the same pattern of acetylation for both $\mathrm{H} 4 \mathrm{~K} 5 \mathrm{ac}$ and $\mathrm{H} 4 \mathrm{~K} 12 \mathrm{ac}$ as for the global $\mathrm{H} 4$ acetylation levels (Figure $3.13 \mathrm{C} / \mathrm{D}$ ). Both residues were acetylated to a lesser extent on the RI assembled chromatin than on chromatin assembled by the RC pathway. A further common acetylation on $\mathrm{H} 4$ is $\mathrm{H} 4 \mathrm{~K} 16 \mathrm{ac}$, a mark present during transcription. Shechter et al. [194] showed that H4K16ac is not present on stored histones in the egg. Nonetheless, I cannot exclude at this point that H4K16ac is involved in the two assembly processes. 


\subsubsection{Determination of acetylation and methylation patterns by mass spectrometry}

Western blot analyses are always limited by the availability of specific antibodies. Especially, antibodies raised against posttranslational protein modifications in a specific sequence context often exhibit cross reactivity or are not available at all. To further substantiate and extend the described Western blot analyses I subjected chromatin derived by the RI and RC pathway to mass spectrometry. Chromatin purified by sucrose gradient centrifugation was analyzed by SDS-PAGE, individual histone lanes were cut out and analyzed by mass spectrometry in collaboration with Axel Imhof, LMU München (see Figure 3.9C for Coomassie-stained gel).

Digest of the H4 band from both chromatin species yielded two peptides (H4 aa 4-17, $\mathrm{H} 4$ aa 20-23) from the N-terminal region that undergo methylation or acetylation (Figure 3.14). The first peptide $\mathrm{H} 4$ aa 4-17 showed extensive acetylation especially in the ssDNA/chromatin. Here, $75 \%$ of all peptides contained one to three acetylation marks and only $25 \%$ of all peptides were unmodified. In contrast, maximal $40 \%$ of H4 1-17 peptides from the dsDNA/chromatin were acetylated and more than $60 \%$ unmodified. Possible acetylation sites include the mentioned H4K5ac and H4K12ac. The global and specific differences in $\mathrm{H} 4$ acetylation observed by Western blot were thus confirmed.

The second peptide H4 aa 20-23 contained the described H4K20 methylation site shown to be monomethylated only in the dsDNA/chromatin by Western blot. However, the mass spectrometry results showed an equal distribution of methylation in both chromatin species. Indeed, roughly $1 / 3$ of all peptides were unmodified, 1/3 monomethylated and 1/3 dimethylated. These results stand in contrast to the Western blot analyses. The shortness of the peptide ( 4 amino acids) and the low signal intensity might be indicators for technical problems during analyses. Since the Western blot analyses and the incorporation of radioactive SAM clearly showed a strong difference between both chromatin assembly pathways (Figure 3.12), I considered the results of the $\mathrm{H} 4$ aa 20-23 as technical artifacts. 
A

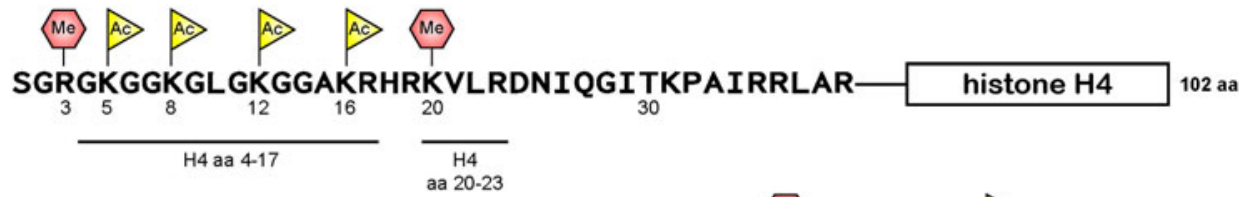

Me methylation Ac> acetylation

B
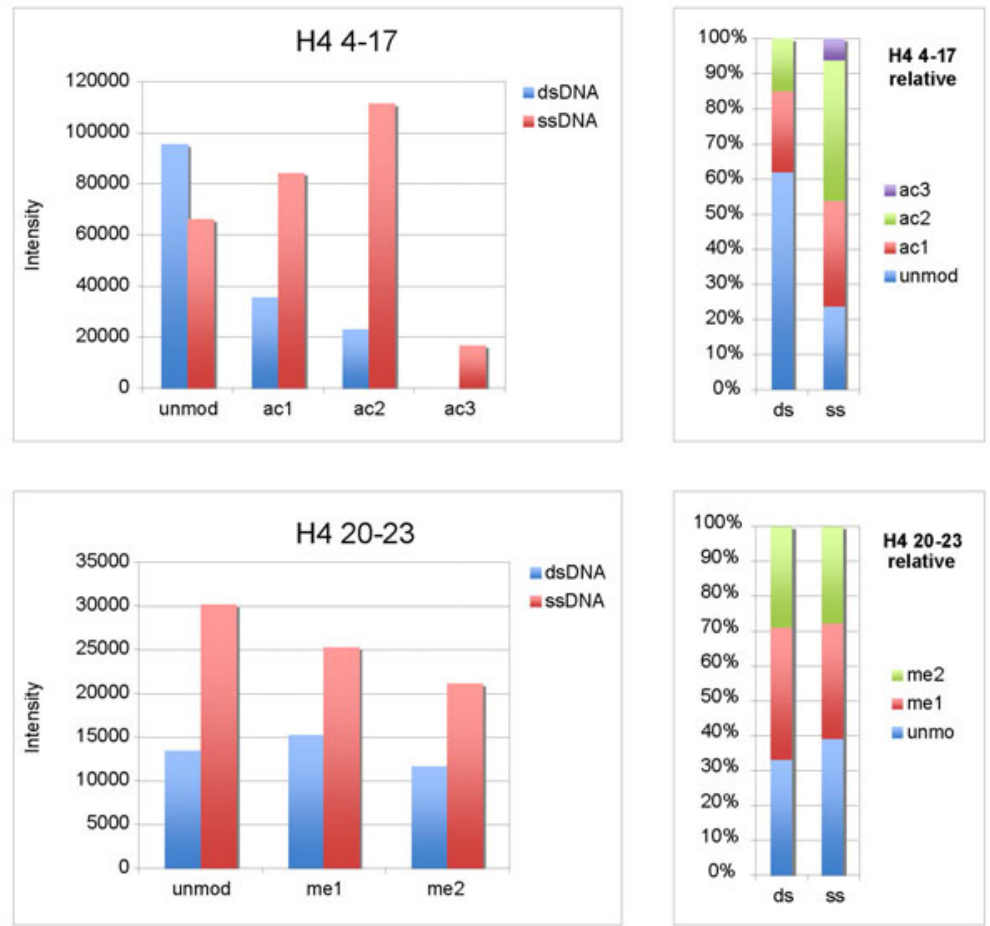

Figure 3.14 | Identification of $\mathbf{H 4}$ methylation and acetylation sites by mass spectrometry. (A) Cartoon of histone $\mathrm{H} 4$ with the N-terminal 39 aa and the histone core domain (boxed). Possible methylation and acetylation sites are indicated (methylation, me, red polygonal / acetylation, ac, yellow flag). Peptides identified by mass spectrometry within the $\mathrm{N}$-terminal regions are labeled. (B) Individual histone $\mathrm{H} 4$ peptides from RC (ss, ssDNA) and RI (ds, dsDNA) assembled chromatin were analyzed in respect to methylation and acetylation of residues. Left panels: Charts showing measured intensities of unmodified peptides (unmod), peptides carrying one to three acetylation sites (ac1-3) or peptides with one to two methylation sites (me1-2). Right panels: The relative amounts of unmodified and modified $\mathrm{H} 4$ peptides in each chromatin sample are presented. Analyses were performed by Axel Imhof (LMU München).

The H3 band of each chromatin species was also analyzed and peptides corresponding to residues 9-17, 18-26 and 27-40 were found and analyzed in respect to modifications (methylation or acetylation). Unfortunately, no information could be retrieved from the $\mathrm{H} 3$ peptide comprising aa 3-8 because of a low signal to noise ratio. Thus no information about the $\mathrm{H} 3 \mathrm{~K} 4 \mathrm{me}$ levels was obtained. Figure 3.15A shows the peptide sequences and the possible methylation and acetylation sites. About 90\% of the $\mathrm{H} 3$ aa 9-17 peptides were unmodified in both chromatin species. A small 
number of peptides, $10 \%$ of the dsDNA/chromatin and $5 \%$ ssDNA/chromatin, carried one methyl mark (Figure 3.15B). Most likely this corresponds to H3K9me1, which has been reported before to associate with newly synthesized H3 histones [106]. The second species of peptides contained either acetylation or trimethylation, which could not be discriminated with the used experimental set-up. It is, however, unlikely that mono- and trimethylation sites but no dimethylation were present because methylation occurs step-wise from mono- over di- to trimethylation. An acetylation was thus more reasonable than trimethylation on the $\mathrm{H} 3$ 9-17 peptide. It is questionable whether this represents $\mathrm{H} 3 \mathrm{~K} 9 \mathrm{ac}$ or $\mathrm{H} 3 \mathrm{~K} 14 \mathrm{ac}$. Both marks are considered active histone modifications that are linked to transcriptionally active regions in the genome [32].

The second peptide, H3 aa 18-26, was also mostly unmodified in both chromatin species (90-95\%) and only a minor fraction of peptides carried one acetylation mark (H3K18ac).

The third peptide analyzed was H3 aa 27-40. Here, two possible methylation sites (H3K27, H3K36) and one acetylation site (H3K27) exist. But as for the other H3 peptides more than $95 \%$ were unmodified and only a minor fraction contained methylation or acetylation sites.

Overall, the data on H3 supported the Western blot data. Acetylation of H3 seemed to be present only in little amounts and no obvious differences were observed between the two chromatin species. The H3K4me could not be investigated due to technical reasons. An additional methylation detected in low amounts was H3K9mel in both chromatin species. The methylation profile of the other peptides confirmed the lack of further methylation sites.

The extensive analyses of $\mathrm{H} 3$ and $\mathrm{H} 4$ histone modifications by Western blot and mass spectrometry revealed new information on RC and RI chromatin assembly. First of all, chromatin assembled RI on dsDNA contains two major sites of methylation: H3K4me1/2/3 and H4K20me1. A third minor site was identified as H3K9me1 in both species. Secondly, acetylation of $\mathrm{H} 4$ is reduced in RI assembled chromatin compared to RC assembled chromatin whereas H3 acetylation levels are comparable between both species. 


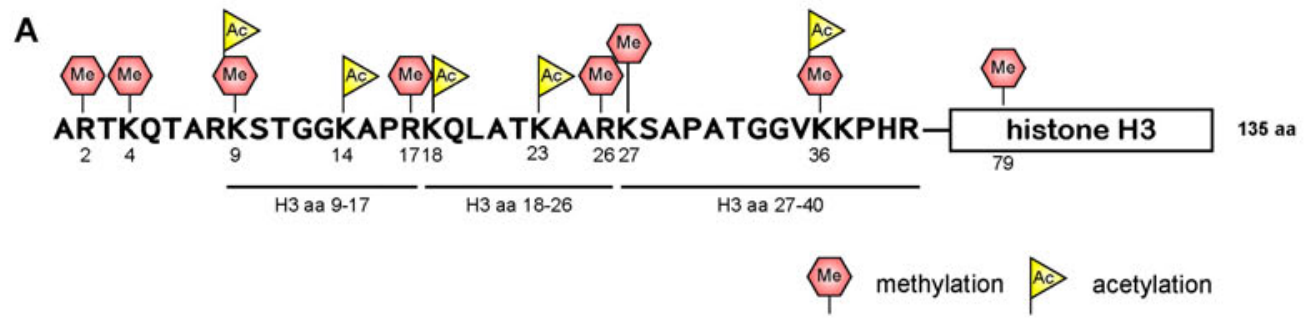

B
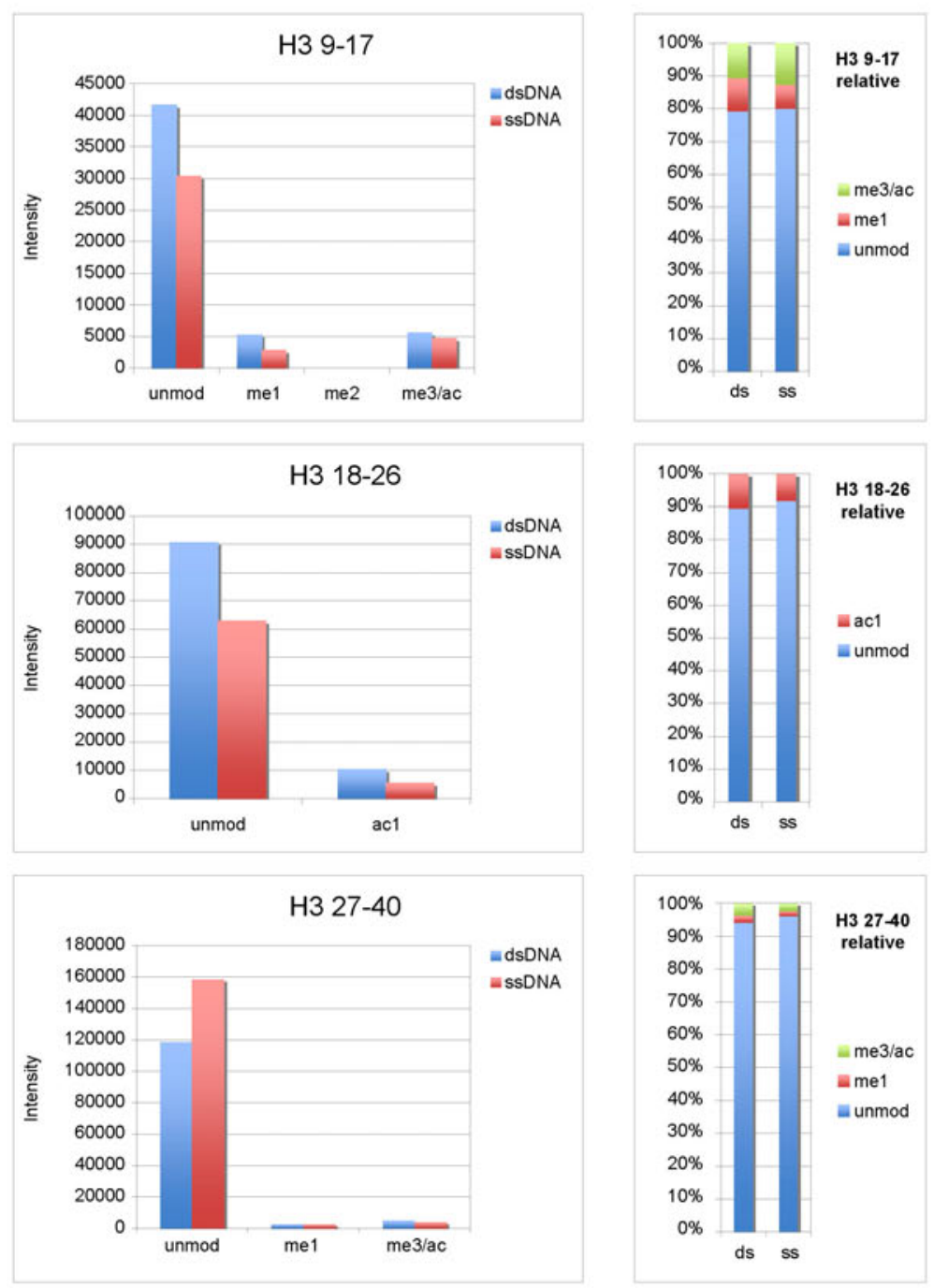

Figure 3.15 | Identification of $\mathrm{H3}$ methylation and acetylation sites by mass spectrometry. (A) Cartoon of histone H3 with the N-terminal 40 aa and the histone core domain (boxed). Possible methylation and acetylation sites are indicated (methylation, me, red polygonal / acetylation, ac, yellow flag). Peptides identified by mass spectrometry within the $\mathrm{N}$-terminal regions are labeled. (B) Individual histone H3 peptides from RC (ss, ssDNA) and RI (ds, dsDNA) assembled chromatin were analyzed in respect to methylation and acetylation of residues. Left panels: Charts showing measured intensities of unmodified peptides (unmod), peptides carrying one acetylation sites (ac1) or peptides with one to three methylation sites (mel-3). Here, acetylation could not be discriminated from trimethylation of the peptide (ac/me3) due to the used settings and instruments. Right panels: The relative amounts of unmodified and modified $\mathrm{H} 3$ peptides in each chromatin sample are presented. Analyses were performed by Axel Imhof (LMU München). 


\subsubsection{Methylation of $\mathrm{H3}$ and $\mathrm{H} 4$ as a result of $\mathrm{RI}$ chromatin assembly}

At this point I asked whether the observed methylations on $\mathrm{H} 3$ and $\mathrm{H} 4$ are a direct result of the assembly or already present on a (small) subpool of stored histones in the egg. I therefore purified chromatin via sucrose density gradients. During centrifugation non-deposited histones are separated from chromatinized histones and can be analyzed separately (Figure 3.6, Figure 3.16). After fractionation of the gradient, $\mathrm{MnCl}_{2}$ was added to each fraction and precipitates were analyzed by Western blot. I probed against H3 and H4 to determine histone and chromatin containing fractions in correlation (Figure 3.16). The Western blot analyses confirmed that free, non-chromatinized histones were separated from the non-chromatinized histones.

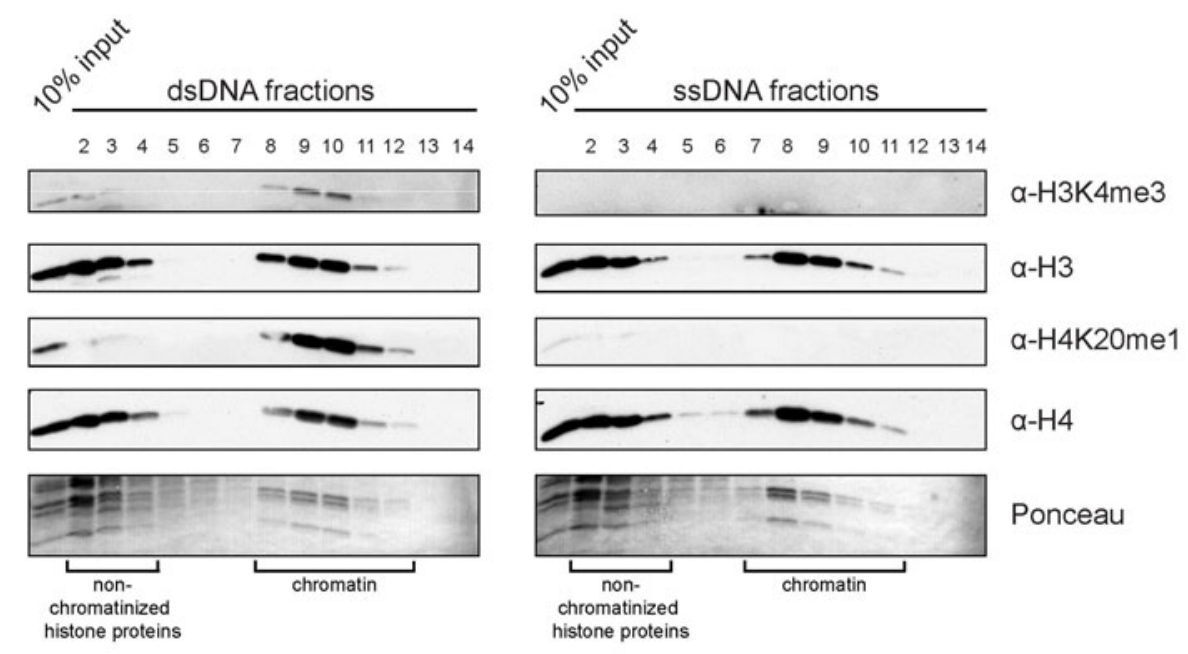

Figure 3.16 | Histone methylation of sucrose gradient purified chromatin. Chromatin assemblies (5 $\mu \mathrm{g}$ total DNA) were loaded onto 10-40\% sucrose density gradients, centrifuged and fractionated (15 fractions). Fractions 2-14 were precipitated with $6 \mathrm{mM} \mathrm{MnCl}_{2}$, separated by SDS-PAGE and analyzed by immunoblotting with anti-H3K4me3 and H4K20me1 antibodies. Chromatin fractions as well as non-chromatinized, histone-containing fractions were identified by Western blot analysis using anti-H3 and anti-H4 antibodies. The input (10\% of the assembly mix) was removed prior to sucrose gradient centrifugation and precipitated with $8 \mathrm{mM} \mathrm{MnCl}_{2}$.

Next, I probed against H3K4me3 and H4K20me1, which I had identified as prominent methylations on dsDNA-derived chromatin. The results showed that these marks were only present on chromatin-associated histones but not on nonchromatinized histones on the dsDNA template. These findings verified that the observed methylation patterns are connected with RI chromatin assembly and are incorporated on chromatin during or shortly after assembly. Acetylation levels were 
not investigated since they were shown before to be already present on the histone pool of the extract (Figure 3.13).

Given the presence of H3K4me and H4K20me1 I wondered whether both marks occur simultaneously or sequentially during chromatin assembly on dsDNA. This would also be indicative for a causal relation between both modifications. RI chromatin assemblies on dsDNA were stopped after increasing time points, precipitated and analyzed for presence of histones $\mathrm{H} 3$ and $\mathrm{H} 4$ and the methyl marks H3K4me1 and H4K20me1. H3 and H4 histones were already visible after $30 \mathrm{~min}$, which is in agreement with the data from the supercoiling assays (compare Figure 3.4A and Figure 3.17A).

A

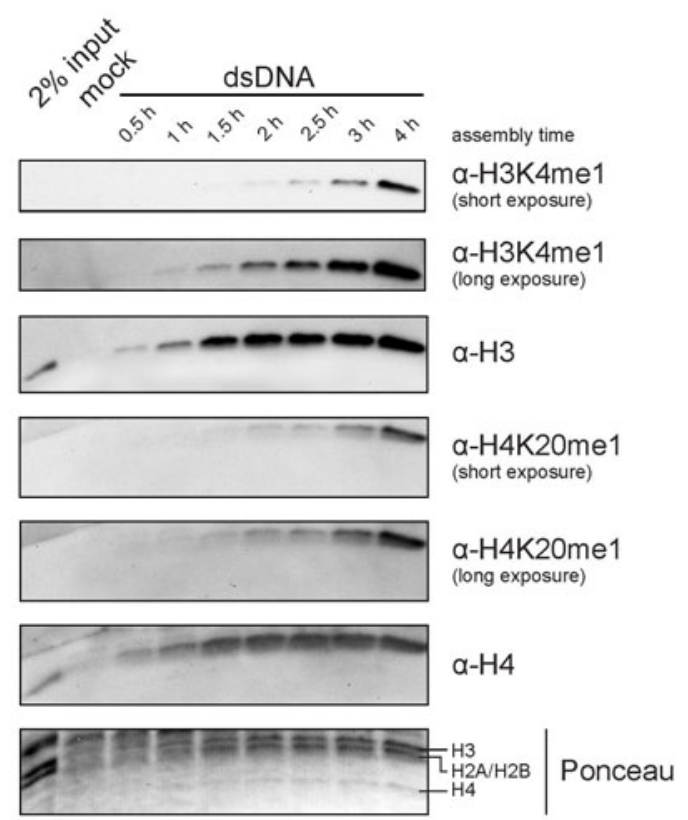

B

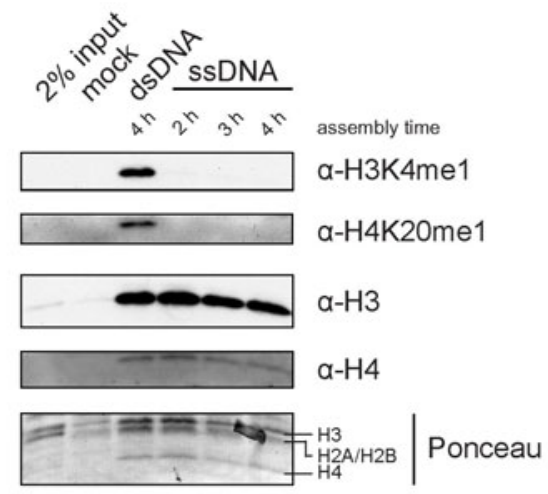

Figure 3.17 | Time-resolved analysis of methylation patterns. (A) Chromatin was assembled on dsDNA in HSE over a time period of $4 \mathrm{~h}$. Samples $(1 \mu \mathrm{g}$ DNA) were removed at increasing time points, precipitated and analyzed by immunoblotting with anti-H3K4me1, anti-H3, anti H4K20me1 and anti-H4 antibodies. Short (1-3 min) and long (10-15 min) exposures are shown for H3K4me1 and H4K20me1 antibodies. (B) Chromatin $(1 \mu \mathrm{g})$ was assembled on dsDNA for $4 \mathrm{~h}$ or ssDNA for 2, 3 and $4 \mathrm{~h}$, precipitated and analyzed in Western blot with the same antibodies as used under A.

The methylation marks on H3 and H4 both appeared before assembly was finished after $4 \mathrm{~h}$. H3K 4 mel was already visible $1.5 \mathrm{~h}$ post DNA addition to the extract whereas H4K20me1 appeared delayed after 2-2.5 h of assembly (Figure 3.17A).

Overall, the H3K4me1 signal appeared earlier and with a higher intensity compared to the H4K20me1 signal. However, it is hard to compare absolute levels between to different antibodies whose detection limits are unknown. Both methylations were 
coupled to assembly since they appeared on dsDNA-derived chromatin before chromatin assembly was complete.

As described RC chromatin assembly on ssDNA occurs more rapidly and is already completed after $2 \mathrm{~h}$ of assembly (Figure 3.4A, Figure 3.5B). So far, histone modifications of both assemblies had been analyzed together after $4 \mathrm{~h}$. To exclude that these marks peak during assembly on ssDNA and are removed later on, I performed a time course on RC assembly on ssDNA. Here, I did not observe methylation of either $\mathrm{H} 3 \mathrm{~K} 4$ or $\mathrm{H} 4 \mathrm{~K} 20$ at $2 \mathrm{~h}, 3 \mathrm{~h}$ or $4 \mathrm{~h}$ after start of assembly (Figure 3.17B).

From the described experiments I concluded that the observed methylations on H3K4 and H4K20 are specifically coupled to the machinery involved in RI assembly and do not associate with RC assembly on ssDNA. The methylation marks were incorporated in a temporarily shifted manner with $\mathrm{H} 3 \mathrm{~K} 4 \mathrm{me}$ appearing before H4K20me1. To further dissect the involved mechanisms of histone variants and to answer the question whether these histone modifications were connected or dependent on each other I next focused on the proteins that are potentially involved in mediating assembly or that contain enzymatic activity.

\subsection{Involvement of non-histone proteins in RI and RC assembly}

The experiments so far described brought up the question which proteins are responsible for the observed biochemical and structural differences. I further wondered whether there is a link existing between the histone modifications and what proteins are involved generating these marks. Mass spectrometry analysis revealed a PR-Set7 like protein (Figure 3.8B). Interestingly, PR-Set7 is the only known histone methyltransferase that monomethylates H4K20. Higher methylation states of H4K20 (me2, me3) are mediated by Suv4-20h1/h2. In contrast to H4K20me1, enzymes mediating $\mathrm{H} 3 \mathrm{~K} 4$ methylation were not detected in the mass spectrometry analyses. I thus first focused on the function of PR-Set7 during assembly. 


\subsubsection{PR-Set7 actively methylates chromatin independent of $\mathbf{H 3 . 3}$ and H3K4me}

I cloned Xenopus laevis PR-Set7 that was identified by homology searches against the human and yeast orthologs. Unlike most methyltransferases PR-Set7 contains only the SET domain as catalytic subunit but no cysteine-rich preSET and postSET domains. Nevertheless, PR-Set7 proteins from different organisms have proven to be functional in methyltransferase assays [36, 39, 153]. A tyrosine residue present in the active site mediates the specificity for monomethylation of H4K20 by PR-Set7. A corresponding residue was identified in the $X$. laevis PR-Set7 (Figure 3.18A). This tyrosine residue is thought to hydrogen bond the monomethyllysine and thus prevents further methylation [35, 37, 40, 41, 195]. In H4K20 HMTs like Suv4-20 that di- and trimethylate $\mathrm{H} 4 \mathrm{~K} 20$ this tyrosine is shifted by 1 residue and sometimes replaced by phenylalanine [35, 195].

In agreement with previous studies on PR-Set7 from various organisms, recombinant $X$. laevis PR-Set7 methylated nucleosomal substrates very efficiently but showed no activity on free histone substrates (Figure 3.18B). I incubated recombinant PR-Set7 with single $\mathrm{H} 3$ and $\mathrm{H} 4$ histones or recombinant mononucleosomes in presence of ${ }^{3} \mathrm{H}$ SAM. This revealed that PR-Set7 only methylated H4 in the context of a nucleosomal structure and showed no activity on other histone proteins. Moreover, this suggested that inside the cell PR-Set7 only methylates chromatinized histone H4 but not the unincorporated protein. That is in agreement with the observation that the soluble histones in the egg extract are not premethylated on H4K20 (Figure 3.16). Therefore, PR-Set7 must be recruited to chromatin. Since I had detected the H3.3 histone variant in the dsDNA-derived chromatin sample, i.e., the sample that exhibited the H4K20me1, I wondered whether PR-Set7 might be targeted to this form of assembly by the presence of this specific H3 variant. To test this hypothesis recombinant PRSet7 was incubated with mononucleosomes containing either the conventional H3.2 or the H3.3 histone protein. The methylation assay revealed that PR-Set7 activity was not increased on H3.3 nucleosomal substrates. Instead PR-Set7 methylated both substrates equally well (Figure 3.18B). 
A

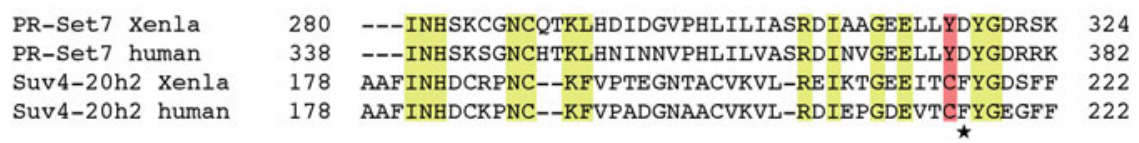

B

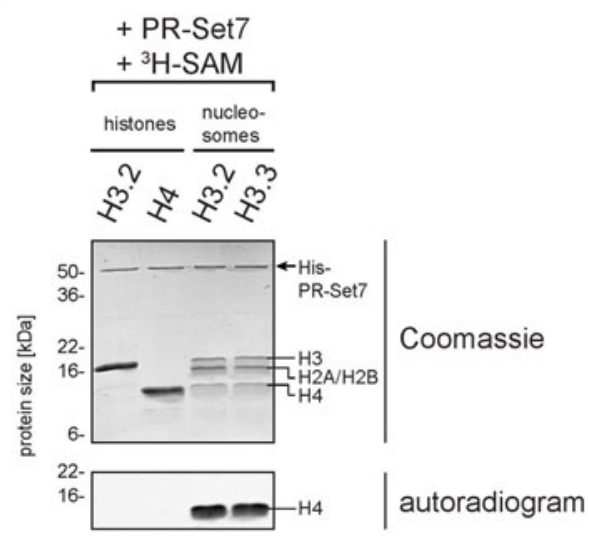

C

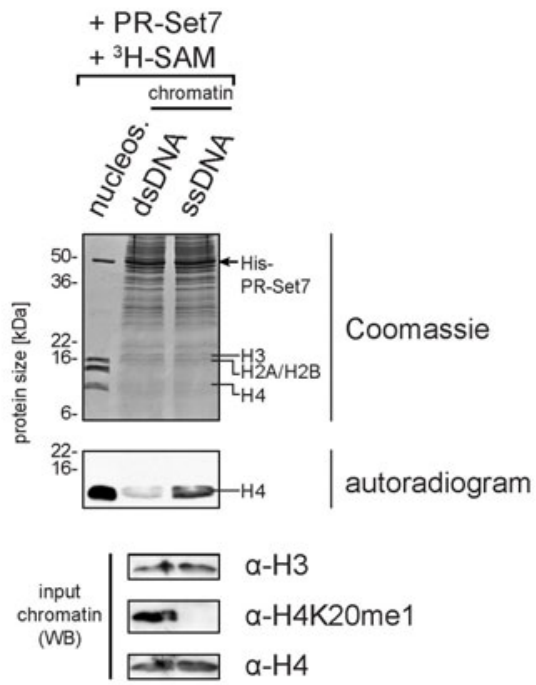

Figure 3.18 | PR-Set7 is not recruited by H3.3 to chromatin derived from dsDNA. (A) Alignment of SET domain fragments of PR-Set7 and Suv4-20h2, which mediate H4K20 methylation specificity by a F/Y switch. The tyrosine of PR-Set7 responsible for monomethyl specificity is highlighted in red. A cysteine at this position in Suv4-20h2 shifts a phenylalanine by 1 residue (marked by a star). This residue is associated with mono-, di, trimethylation of H4K20 in Suv420. Identical residues are highlighted in yellow. PR-Set7 Xenla (NP_001121300), PR-Set7 human (NP_065115), Suv4-20h2 Xenla (NP_001090519), Suv4-20h2 human (NP_116090). (B) Methyltransferase activity of recombinant PR-Set7 was tested on free histones $\mathrm{H} 3$ and $\mathrm{H} 4$ and on mononucleosomal substrates containing H3.2 or H3.3 histones. Substrates $(2 \mu \mathrm{g})$ were incubated with His-tagged PR-Set7 $(1 \mu \mathrm{g})$ in presence of ${ }^{3} \mathrm{H}$-SAM. The reactions were separated by SDS-PAGE and analyzed by autoradiography ( $4 \mathrm{~h}$ exposure). (C) Methyltransferase assay on chromatin assembled in HSE and purified by sucrose density gradient centrifugation. Chromatin $(\sim 0.5 \mu \mathrm{g})$ and mononucleosomes (H3.2) were incubated with His-tagged PR-Set7 $(1 \mu \mathrm{g})$ in presence of ${ }^{3} \mathrm{H}$-SAM. Samples were treated and analyzed as described under B. Below the autoradiogram a Western blot (WB) of gradient-purified chromatin is shown using anti-H3, anti-H4K20me1 and anti-H4 antibodies.

Since PR-Set7 was not recruited by H3.3 to the RI assembly on dsDNA, I asked whether a principal restriction exists that prevents methylation of ssDNA-derived chromatin by PR-Set7. I therefore purified dsDNA- and ssDNA-derived chromatin by sucrose gradient centrifugation and then subjected both chromatin species to an in vitro methylation assay using recombinant PR-Set7. Western blot analysis verified that dsDNA-derived chromatin was pre-marked by H4K20me1 whereas the ssDNAderived chromatin was void of any H4K20 methylation at the start of the assay (see input Figure 3.18C). Notably, PR-Set7 did efficiently methylate the ssDNA-derived chromatin that lacked the H4K20 methylation. This methylation exceeded the degree of H4K20 methylation imposed on the dsDNA-derived chromatin sample, which 
reflects the existing H4K20 methylation on this chromatin species. The results implicated that dsDNA-derived chromatin is quite exhaustively monomethylated on H4K20 in the egg extract. Moreover, this suggested again that PR-Set7 is not recruited by H3.3 to chromatin. Instead, PR-Set7 must be recruited by the RI assembly machinery or factors associated only with dsDNA-derived chromatin after the assembly process. Another explanation is that the sucrose purification of chromatin removed factors that inhibit methylation by PR-Set7 during assembly.

Besides H3.3, the different acetylation intensities observed on H4 (Figure 3.13B/C) did not have an impact on PR-Set7 function. Another study using Drosophila PR-Set7 also demonstrated that the enzyme does not distinguish between nucleosomes containing acetylated or non-acetylated histone H4 [153].

The interplay of different histone modifications and their cognitive enzymes and binding partners is known as cross-talk [56]. For instance, a combination of H3K4me with $\mathrm{H} 3 \mathrm{~K} 9 \mathrm{ac}$ results in transcriptional activation whereas $\mathrm{H} 3 \mathrm{~K} 9 \mathrm{me}$ and $\mathrm{H} 3 \mathrm{~K} 14 \mathrm{ac}$ lead to repression. This cross talk is not limited to the histone level or one histone species. An interesting example is the requirement of H2B ubiquitination by Rad6 for methylation of H3K79 by Dot1 [196, 197].

That led to the question whether H3K4me and H4K20me1 are interconnected in the assembly pathway. Since H3K4me1 precedes H4K20me1 during assembly, PR-Set7 might be recruited by interaction with $\mathrm{H} 3 \mathrm{~K} 4 \mathrm{me} 1$ to the dsDNA-derived chromatin. I examined the impact of $\mathrm{H} 3 \mathrm{~K} 4 \mathrm{me} 3$ on PR-Set7 methylation activity by HMT assays on chromatin containing unmodified H3 (H3 wt) or H3K4me3. The recombinant chromatin arrays consisting of a linear 12mer oligonucleosomal structure were prepared by salt dialysis and the methylated histone $\mathrm{H} 3$ was produced by native chemical ligation [144] (Figure 3.19A). The HMT assay showed that PR-Set7 methylated unmodified and modified chromatin on $\mathrm{H} 4$ to a similar extent irrespective of H3K4me3 (Figure 3.19B).

Consistent with that finding recombinant PR-Set7 did not bind to unmodified or H3K4me3 peptides (H3 aa 1-15) in fluorescence polarization assays (data not shown, [198]). 
A

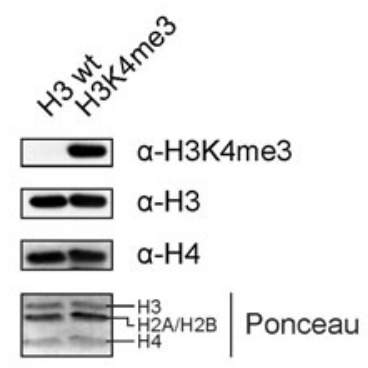

B

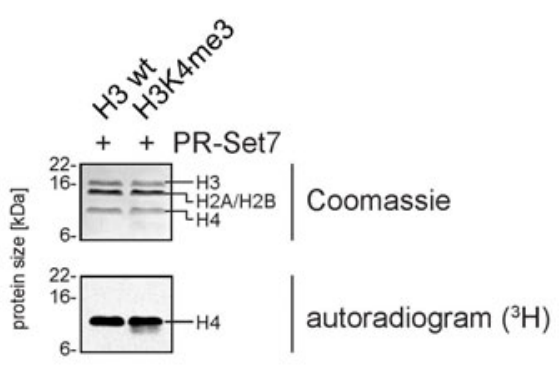

Figure 3.19 | PR-Set7 activity does not depend on H3K4me. Chromatin arrays containing either wildtype (wt) or $\mathrm{H} 3 \mathrm{~K} 4 \mathrm{me} 3$ histones were prepared to test methyltransferase activity of recombinant PR-Set7. (A) Western blot analysis of chromatin arrays. $2 \mu \mathrm{g}$ chromatin was blotted and analyzed with anti-H3K4me3, anti-H3 and anti-H4 antibodies. (B) Methyltransferase assay on chromatin arrays $(2 \mu \mathrm{g})$ was performed in presence of ${ }^{3} \mathrm{H}-\mathrm{SAM}$ and recombinant PR-Set7 $(10 \mathrm{ng})$ for $15 \mathrm{~min}$ at $30^{\circ} \mathrm{C}$ and analyzed by autoradiography.

The experiments on PR-Set7 activity revealed that it methylates H4K20 only in a nucleosomal context. Its activity is not dependent on H3.3, H3K4 methylation or H4 acetylation. An interesting finding was that recombinant PR-Set7 can methylate ssDNA-derived chromatin purified after assembly whereas the endogenous enzyme was not associated with RC assembly on ssDNA. This implies that either factors that restrict access of PR-Set7 to chromatin are removed during purification or that PRSet7 is recruited to chromatin through interaction with other proteins, which are directly involved in the assembly process.

\subsubsection{PR-Set7 does not interact with HIRA}

Since PR-Set7 showed no connection to H3.3 or H3K4me I explored its possible interaction with the RI assembly machinery. The only factor that was reproducibly demonstrated to be actively involved in RI assembly is the H3-H4 chaperone HIRA $[20,97,124]$.

HIRA is a relatively large protein $(112 \mathrm{kDa})$ and I decided to express it recombinantly in an in vitro translation \& transcription system (TNT kit, Promega). HIRA was cloned with a C-terminal double FLAG tag and after expression incubated with either GST or GST-PR-Set7 that had been immobilized to glutathione beads. After a washing step the beads were analyzed by Western blot for presence of GST-/GST-PR-Set7 and HIRA. The Western blot revealed no specific interaction of HIRA and GST-PR-Set7. Only an unspecific interaction of recombinant HIRA with either GST or the beads matrix was observed (Figure 3.20A). To exclude that the recombinant HIRA was 
misfolded or its sequence not annotated correctly, I repeated the GST/GST-PR-Set7 pulldowns in egg extract (HSE) to investigate the interaction of PR-Set7 with endogenous HIRA. Moreover, this strategy would also detect indirect interaction between HIRA and PR-Set7 via bridging factors. Endogenous levels of HIRA were visualized by a specific antibody raised against $X$. laevis HIRA (xHIRA) [97] (Figure 3.20B input lane). The GST pulldowns in HSE confirmed the results of the previous pulldown with recombinant protein, as I could not detect any an interaction between PR-Set7 and HIRA.

A

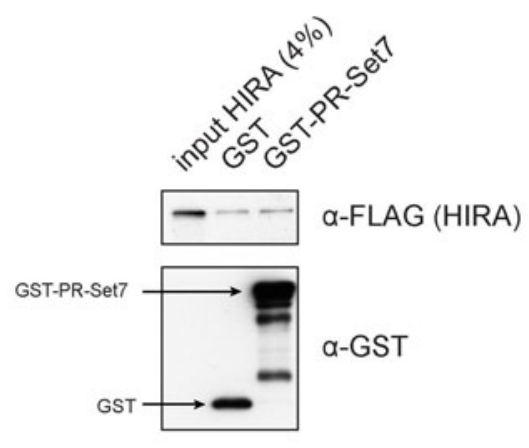

B

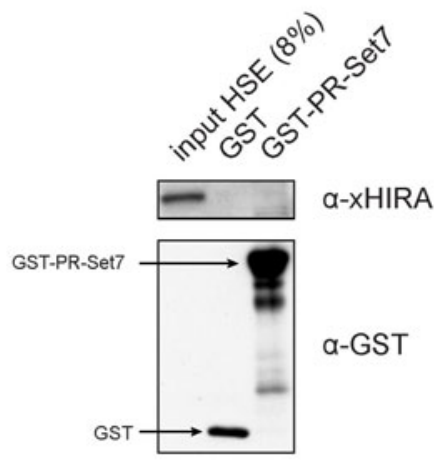

Figure 3.20 | PR-Set7 does not interact with HIRA. Protein-protein interactions were analyzed with GST pulldown assays using immobilized GST and GST-PR-Set7 proteins. (A) GST pulldown with in vitro translated HIRA (FLAG-tagged). Western blot against HIRA (anti-FLAG antibody) and GST (anti-GST antibody) is shown. (B) Western blot analysis of GST pulldown in X. laevis egg extract (HSE). The membrane was probed with anti-xHIRA antibodies and an anti-GST antibody to analyze potential interactions.

The performed experiments did not reveal an interaction between HIRA and PR-Set7. Moreover, H4K20me1, the modification mediated by PR-Set7, could not be linked to other characteristics found in the dsDNA-derived chromatin like H3.3 and H3K4 methylation. However, H3.3 was demonstrated to be complexed by HIRA [20] and many studies demonstrated the importance of this $\mathrm{H} 3$ variant for RI assembly [16, 20, 22, 119, 124]. Therefore, I tested the influence of HIRA and on the discovered H3K4 methylation, a histone mark predominantly found on H3.3 histones in vivo [115]. 


\subsubsection{HIRA associates with an H3K4 methyltransferase}

The H3-H4 histone chaperone HIRA is known to bind H3.3 and is involved in RI assembly. Depletion studies showed that removal of HIRA dramatically impairs RI assembly. However, re-addition of recombinant HIRA to the system did not restore this activity whereas immunoprecipitated H3.3/HIRA complexes were able to partially restore the assembly pathway [20]. These findings imply that HIRA has to interact with other proteins to carry out assembly. Interaction partners identified so far are the H3-H4 chaperone Asf1 [97, 127], FACT [199] and small proteins named HIRIP in yeast or ubinuclein1 in mammals [200, 201]. Asf1 and FACT are related to HIRA's ability to bind H3.3 and potentially to transcriptional activation as FACT is important for histone removal during transcription. Another intriguing observation is the co-localization of $\mathrm{H} 3.3$ and $\mathrm{H} 3 \mathrm{~K} 4 \mathrm{me} 3$ to certain genomic loci that exhibit high transcriptional activity $[114,115]$.

I reasoned that there might be a direct connection between HIRA, H3.3 incorporation and H3K4me. To follow up on this idea I immunoprecipitated HIRA from the egg extract with the anti-xHIRA antibody (Figure 3.21A). The immunoprecipitate was subjected to a methyltransferase assay on mononucleosomal substrates in presence of ${ }^{3} \mathrm{H}-\mathrm{SAM}$. Indeed, the autoradiogram revealed that the HIRA-IP associated with a methyltransferase activity specific for histone H3. In contrast, I did not observe methylation of histone $\mathrm{H} 4$, a finding that indirectly confirmed the experiments on PRSet7-HIRA interaction (Figure 3.20).

Considering the experiments to that point it seemed likely that this methylation was on H3K4 because H4K20me1 and PR-Set7 showed no connection to HIRA. However, the methylation intensities were quite low and I could not confirm this hypothesis by Western blot. To tackle this question, I tested whether the HIRAassociated methyltransferase can still methylate $\mathrm{H} 3$ that contains H3K4me3. Trimethylation was used because it cannot be further methylated and thus renders the $\mathrm{H} 3 \mathrm{~K} 4$ residue unavailable for methylation. In case not $\mathrm{H} 3 \mathrm{~K} 4$ is affected by methylation I would still detect incorporation of ${ }^{3} \mathrm{H}$-methyl in such an assay. Therefore, I repeated the HIRA-IP and subjected it this time to an HMT assay using either unmodified or H3K4me3-modified chromatin arrays (see Figure 3.19A). This experiment demonstrated that the presence of $\mathrm{H} 3 \mathrm{~K} 4 \mathrm{me} 3$ efficiently blocked the methylation activity associated with HIRA (Figure 3.21B). These results clearly 
suggested that HIRA associates with an $\mathrm{H} 3 \mathrm{~K} 4$ methyltransferase that presumably methylates newly deposited histone $\mathrm{H} 3$ during assembly.

A

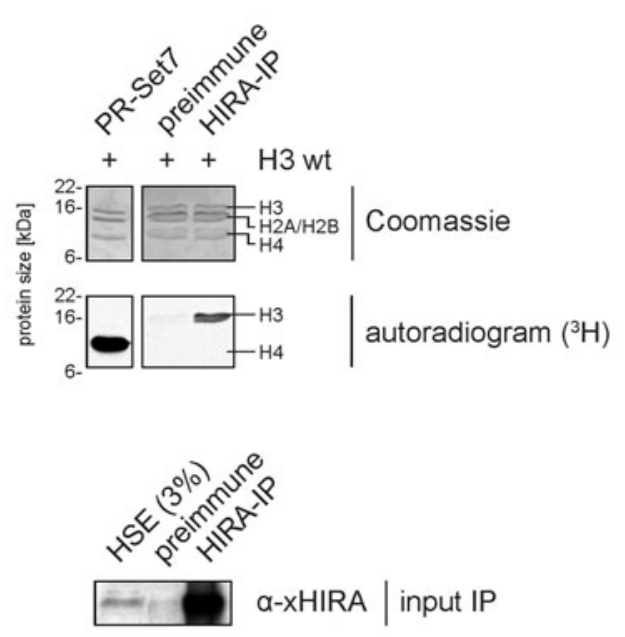

B

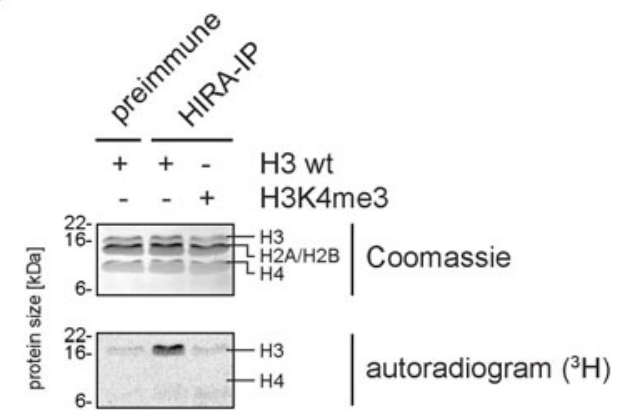

Figure 3.21 | HIRA associates with an H3K4 methyltransferase. (A) Top: Immunoprecipitation (IP) from HSE using preimmune serum or anti-xHIRA antibodies. Each IP was incubated with mononucleosomes carrying H3 wt (H3.2) histones in presence of ${ }^{3} \mathrm{H}-\mathrm{SAM}$. Recombinant PR-Set7 was incubated with the same substrate as a positive control and as a size reference for methylated products. Coomassie-stained gel of substrates and the respective autoradiogram is shown. Bottom: Western blot of immunoprecipitated material used in A. Immunoaffinity beads were boiled after IP in SDS sample buffer and analyzed by Western blot with anti-xHIRA antibodies. (B) Methyltransferase assay on chromatin containing $\mathrm{H} 3$ wt or $\mathrm{H} 3 \mathrm{~K} 4 \mathrm{me} 3$ histones with immunoprecipitated material as described under A. Coomassie-stained gel of substrates and the respective autoradiogram are shown.

H3K4 methyltransferases have not been characterized so far in Xenopus laevis. Similarity searches in a genome library (www.xenbase.org) showed that at least five members of the mixed leukemia lineage (MLL 1-5) protein family as well as ASH1, Set7 and SMYD3 homologs exist. Homologs of these proteins were shown to exhibit H3K4 methyltransferase activity in other organisms [202]. Up to date, at least ten H3K4 methyltransferases with mostly non-redundant functions are known to exist in mammals whereas $S$. pombe contains just one H3K4 methyltransferase (Set1). It remains to be seen whether one of these methyltransferases associates with HIRA in mammals and which methyltransferase is responsible for the observed H3K4 methylation in the frog egg extract.

Overall the biochemical characterization of chromatin derived by the two assembly pathways revealed that the chromatin species show variations in associated proteins, 
histone variants and histone modifications. Further, a link between the H3K4 methylation and HIRA, a key player in the RI assembly assembly, was established. Together with the structural data this indicated that both chromatin species are different due to the pathway they were generated by.

One remaining question was whether a specific assembly pathway directly implements a functional feature or competency by introducing these modulations on chromatin structure.

\subsection{Functional consequences of RI and RC assembly pathways}

After the topological and biochemical analysis of both chromatin species I investigated whether the observed differences could be transferred to a functional level. The found 'active' marks (H3K4me1/2/3) on dsDNA-derived chromatin brought up the question whether the transcriptional activity of the two chromatin species differed.

In order to investigate transcription of the derived chromatin species, the used DNA templates had been constructed to contain a transcriptional unit from the parental $\mathrm{pG}_{5} \mathrm{ML}$ plasmid (Figure 3.2). This unit contained a strong promoter (AdML), five GAL4-UAS elements to recruit GAL4-fusions proteins and a G-less cassette. Transcriptional activators like GAL4-VP16 can be tethered to the transcriptional unit via the GAL4-UAS sites and thereby activate transcription in concert with other basal transcription factors. The source of these factors is often a cellular or nuclear extract (e.g. HeLa cell nuclear extract). Using radioactive nucleotides the generated transcripts can be easily visualized afterwards by autoradiography. To aid the analysis and remove aberrant transcripts the G-less cassette is used. Its transcript cannot be digested by a G-specific RNase (RNase T1) and thus accumulates after an RNase T1 digest and can be purified [137].

\subsubsection{The high-speed egg extract cannot mediate transcription}

The first idea was to compare both chromatin species at the end of chromatin assembly by initiating transcription with the transcription activator GAL4-VP16 [203]. A major obstacle, however, was that transcription is highly restricted in $X$. 
laevis egg extract. Xenopus eggs undergo rapid cell divisions depending on the maternal stockpiles of proteins and RNA and remain transcriptionally silent until midblastula transition (MBT). The large excess of histones and thus the assembly process is thought to compete with the transcriptional machinery for access to DNA $[158,204]$. As the DNA/histone ratio increases during the first 12 cell divisions until MBT, the repression is relieved [205]. Moreover, the egg seems to be deficient for transcriptional activators like TBP [206, 207].

Indeed, I could demonstrate that the extract itself is not capable of inducing transcription in an in vitro assay on naked DNA or chromatin assembled in the extract. As shown in Figure 3.22 naked dsDNA ( $\left.\mathrm{pG}_{5} \mathrm{ML}\right)$ was actively transcribed using HeLa cell nuclear extract (lane 1). On the contrary, HSE from $X$. laevis eggs did not activate transcription on the naked DNA template (lane 2), which most likely also reflects its deficiency in basal transcription factors. Addition of equal amounts of both extracts induced transcription of the G-less cassette but also aberrant transcripts (lane 3). The activation of transcription on naked DNA was dependent on the activator GAL4-V16 (lanes 4-5) and thus did not represent a basal transcription level. A second labeled nucleic acids species was observed upon addition of HSE that was much bigger than the expected transcript of the G-less cassette. This species was identified as DNA by digest with RNase A and DNase I (data not shown). I assume that the egg extract contains ribonucleotide reductase that converts radioactively labeled NTPs to dNTPs, which are incorporated into nicked DNA templates.

Like the naked DNA template, chromatin assembled in the egg extract was not accessible for transcription when used in the in vitro assay (Figure 3.22, lanes 6-8). Chromatin itself is a repressive structure but transcription can be induced in vitro on recombinant chromatin using activators like GAL4-VP16, acetyltransferases like p300 and basal transcription factors [130]. However, the addition of these factors did not initiate transcription of chromatin in the assembly mix. I only observed very low levels of transcript that must be attributed to basal transcription since they appeared independent of GAL4-VP16 addition (lane 8). 


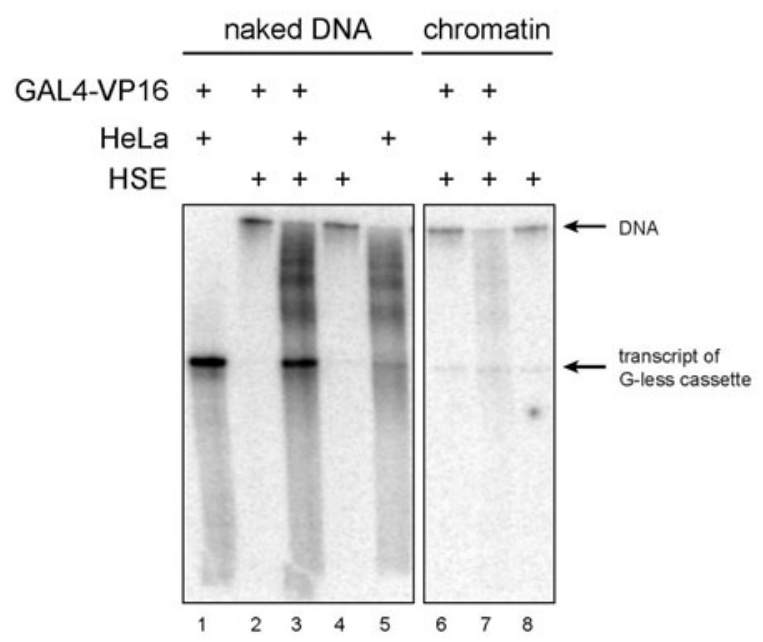

Figure 3.22 | Egg extract is not capable of inducing transcription. Transcription was performed using either $100 \mathrm{ng}$ naked $\mathrm{pG}_{5} \mathrm{ML}$ plasmid or $\mathrm{pG}_{5} \mathrm{ML}$ assembled in egg extract in presence of $\left[\alpha_{-}{ }^{32} \mathrm{P}\right]$ CTP. Naked DNA (lanes 1-5) was incubated \pm GAL4-VP16 (25 ng) and with Hela nuclear extract $(1,4)$, HSE $(2,5)$ or both extracts (3). Chromatin was assembled in HSE (6-8) and the assembly mix was incubated \pm GAL4-VP16. HeLa extract was added in lane 7. Naked DNA as well as chromatin assembly reaction were supplemented with nucleotides and salts $(0.5 \mathrm{mM} \mathrm{NTPs}, 2 \mathrm{mM} \mathrm{MgCl}, 2 \mathrm{mM}$ spermidine, $20 \mathrm{mM}$ creatine phosphate, $10 \mathrm{mM}$ HEPES $\mathrm{pH}$ 7.8). Transcription reactions were digested with RNase T1. RNA was purified, separated by denaturing PAGE and analyzed by autoradiography. Autoradiograms were taken from one gel exposed for $48 \mathrm{~h}$. Irrelevant lanes were omitted for clarity.

\subsubsection{RI assembly leads to transcriptional active chromatin}

I reasoned that extract-assembled chromatin might be used in transcription assays after purification, i.e., removal of excess histones, and supplementation with exogenous transcription activators from HeLa nuclear extract.

Therefore, I used chromatin purified by sucrose density gradient centrifugation and subjected it to the transcription assay. Chromatin-containing fractions of sucrose gradients were first dialyzed to remove sucrose against a buffer containing $50 \mathrm{mM}$ $\mathrm{KCl}$, which is similar to the salts concentrations present in the extract $(50-70 \mathrm{mM}$, [148]). Then, following binding of GAL4-VP16, chromatin was acetylated by addition of p300 and Acetyl-CoA. HeLa nuclear extract was added to promote assembly of the preinitiation complex with factors present in the nuclear extract. Transcription was induced by addition of nucleotides (cold NTPs and $\left[\alpha-{ }^{32} \mathrm{P}\right]$ CTP). The resulting radioactively labeled transcripts were digested with RNase T1, separated by denaturing PAGE and analyzed by autoradiography (scheme shown in

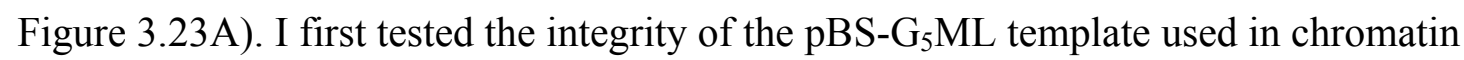
assemblies. The G-less cassette from the parental $\mathrm{pG}_{5} \mathrm{ML}$ that had been inserted into 
the pBS- $\mathrm{G}_{5} \mathrm{ML}$ template was functional in the in vitro assay on naked dsDNA (plus HeLa extract) and showed no differences compared to the parental construct (Figure 3.23B). Next assembled chromatin was purified by sucrose gradient centrifugation to remove excess histone proteins and submitted to the assay (Figure 3.23D).

A

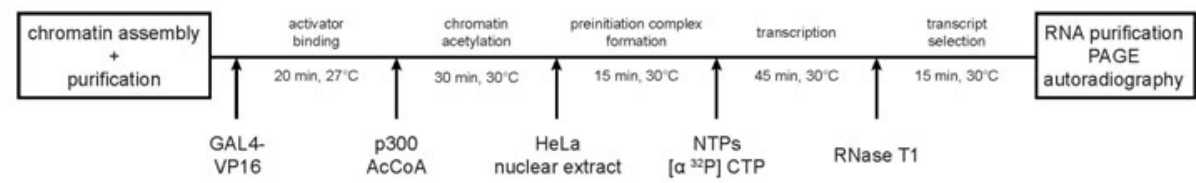

B

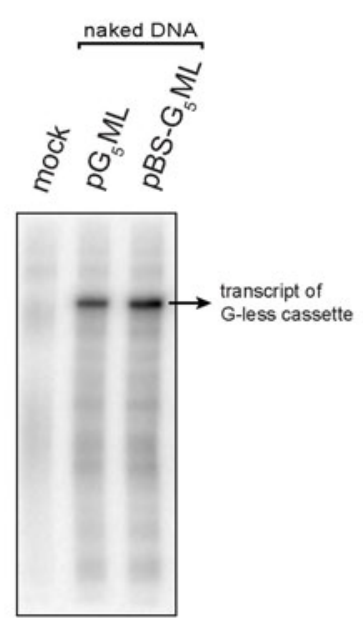

C

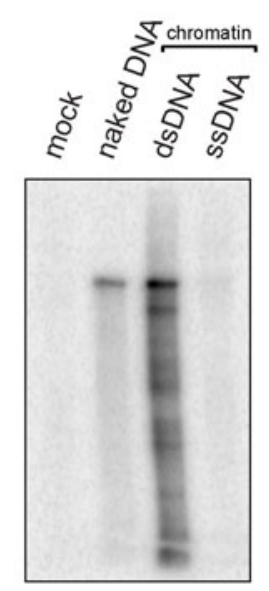

D

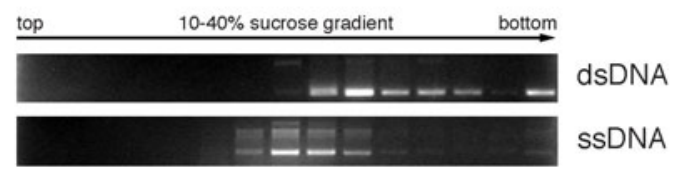

E

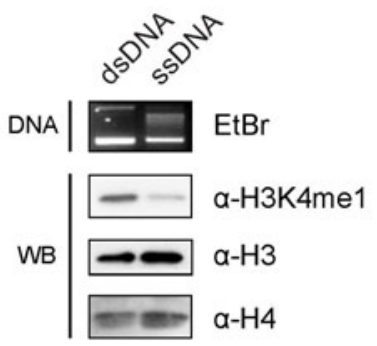

Figure 3.23 | Chromatin assembled on ssDNA is refractory to transcription. (A) Flow diagram of transcriptional assay. After chromatin assembly in HSE and purification by sucrose density gradient centrifugation, GAL4-VP16 transcriptional coactivator is added followed by p300 acetyltransferase, Acetyl-CoA (AcCoA) and HeLa nuclear extract. The transcription reaction is started by addition of NTPs and $\left[\alpha-{ }^{32} \mathrm{P}\right]$ CTP. Transcripts of the G-less cassette are selected by digest with RNase T1 and RNA is purified, separated by denaturing PAGE and analyzed by autoradiography. (B) Autoradiogramm of a transcription reaction containing either no DNA (mock) or $100 \mathrm{ng}$ of naked DNA templates $\left(\mathrm{pG}_{5} \mathrm{ML}, \mathrm{pBS}-\mathrm{G}_{5} \mathrm{ML}\right)$. $\mathrm{pBS}-\mathrm{G}_{5} \mathrm{ML}$ carries the transcriptional cassette of the parental $\mathrm{pG}_{5} \mathrm{ML}$ construct. (C) Transcriptional activity of $50 \mathrm{ng}$ chromatin assembled on either ds or ss $\mathrm{pBS}-\mathrm{G}_{5} \mathrm{ML}$ was compared together with naked $\mathrm{pBS}_{5} \mathrm{G}_{5} \mathrm{ML}$ and a mock control. (D) Sucrose density gradient centrifugation of the chromatin samples used in C. $10 \%$ of each fraction was digested with RNase A, deproteinized and analyzed by agarose gel electrophoresis. (E) DNA/chromatin input of the samples analyzed under C. DNA (100\% input C) was extracted from chromatin samples and run on an agarose gel. Chromatin was precipitated with $8 \mathrm{mM} \mathrm{MnCl}_{2}$ and analyzed by immunoblotting with anti$\mathrm{H} 3 \mathrm{~K} 4 \mathrm{me} 1$, anti-H3 and anti-H4 antibodies. Note: for precipitation the amount of chromatin was doubled compared to the experiment shown in $\mathrm{C}$. 
The transcriptional analysis of the purified chromatin fractions revealed that only chromatin derived from dsDNA was transcribed but not chromatin assembled on ssDNA (Figure 3.23C). The integrity of chromatin input was verified by Western blot analysis using anti-H3/H4 and anti-H3K4me1 antibodies. Moreover, DNA was extracted and analyzed by agarose gel electrophoresis (Figure 3.23E). These findings suggest that RC assembly leads to transcriptionally repressed chromatin whereas chromatin assembled via RI pathway has the potential to be transcribed.

\subsubsection{Transcription is dependent on methylation of chromatin}

The results of the transcriptional read-out raised the question whether a connection exists between the methylations present on chromatin derived by RI assembly and its transcriptional capacity. All states of $\mathrm{H} 3 \mathrm{~K} 4 \mathrm{me}$ have been linked to sites of transcriptional activity [202]. Methylation can be blocked using S-adenosyl-Lhomocysteine (SAH). SAH is the product of methyltransferase reactions using Sadenosyl-L-methionine (SAM) and a potent competitive inhibitor of methyltransferase activity. Chromatin assemblies in the presence of SAH led to depletion of the H3K4me and the H4K20me1 mark (Figure 3.24A). Chromatin assembly itself showed no impairment as demonstrated by presence of core histones in Western blots. Nevertheless, applying AFM I detected structural changes. Indeed, the unmethylated dsDNA-derived chromatin looked similar to ssDNA-derived chromatin (Figure 3.7) but exhibited less tendency to aggregate. The spherical particles were very much alike in diameter and height $(60 \mathrm{~nm} / 20 \mathrm{~nm})$.

However, these differences were not reflected to a similar degree in sucrose density gradients centrifugations. Here, the hydrodynamic behavior of the unmethylated chromatin did not vary considerably from that of methylated chromatin (Figure 3.25B). The gradient-purified chromatin was then subjected to transcriptional analysis in the described assay. 
A

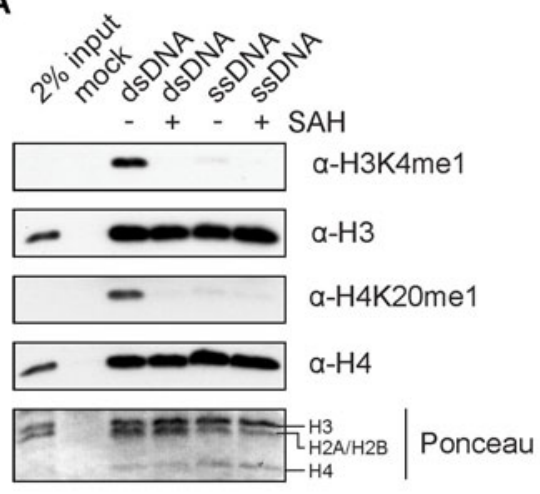

B
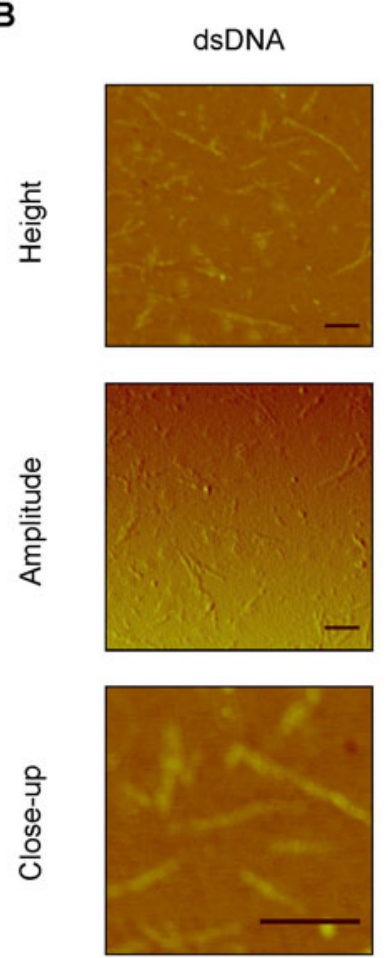

dsDNA+SAH
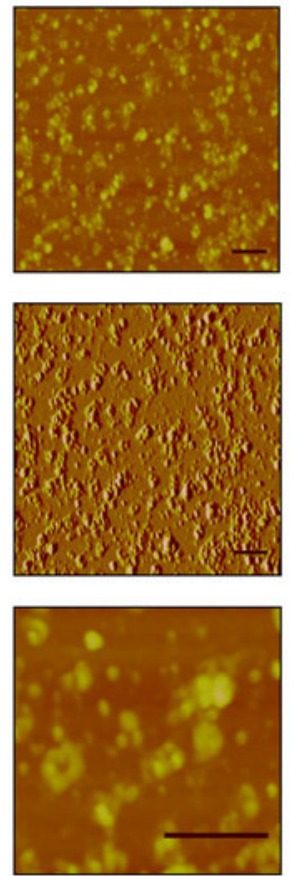

Figure 3.24 | SAH inhibits methylation on dsDNA derived chromatin. (A) Chromatin assembly was performed in presence or absence of the methyltransferase inhibitor S-Adenosyl-L-homocysteine $(\mathrm{SAH})$ and chromatin was analyzed after precipitation by immunoblotting with anti-H3K4me1, anti$\mathrm{H} 3$, anti-H4K20me1 and anti-H4. (B) AFM images of chromatin assembled on dsDNA \pm SAH. Two representations (height/amplitude) and a close-up are shown. The scale bar corresponds to $200 \mathrm{~nm}$ in each image.

The transcriptional assay demonstrated that the unmethylated chromatin was transcribed less efficiently than the methylated form. Thus the methylation imposed by the assembly pathway is of major importance for mediating transcriptional activity (Figure 3.25A). Transcriptional activity was not completely abolished as in ssDNAderived chromatin sample. It is thus reasonable that other features like the presence of $\mathrm{H} 3.3$, variations in histone acetylation and associated proteins as well as the overall chromatin structure contribute to some extend to the transcriptional capacity of the RI chromatin.

The transcriptional analyses revealed that chromatin assembled by the RI pathway on dsDNA can be transcribed in an in vitro assay whereas ssDNA-derived chromatin was transcriptionally silent. Histone methylation proved to be largely responsible for the observed transcriptional capacity. From the experiments it could not be deduced, which methylation mark, $\mathrm{H} 3 \mathrm{~K} 4 \mathrm{me}$ or $\mathrm{H} 4 \mathrm{~K} 20 \mathrm{me} 1$, is responsible for transcriptional activity or whether both marks have an impact.c 
A

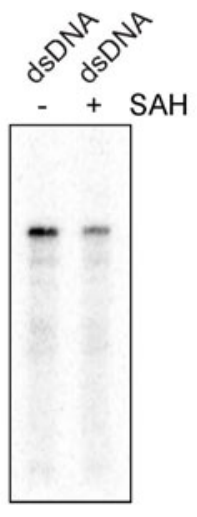

B

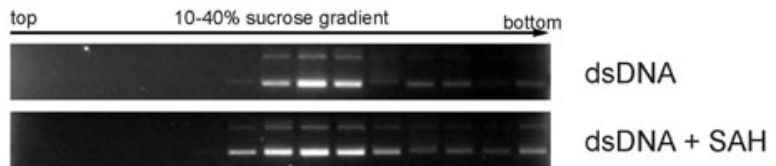

C

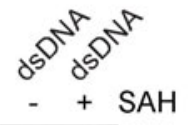

$=$

Figure 3.25 | Methylation marks on dsDNA chromatin species enhance transcriptional activity. (A) Chromatin was assembled on dsDNA $\pm \mathrm{SAH}$ and purified by sucrose density gradient centrifugation. The purified chromatin was subjected to the transcription assay. The autoradiogram of the transcription assay is shown. (B) Sucrose density gradient centrifugation of chromatin assemblies on dsDNA $\pm \mathrm{SAH}$. $10 \%$ of each fraction was digested with RNase A, deproteinized and analyzed by agarose gel electrophoresis (ethidium bromide stained). (C) DNA input of the samples analyzed under A. Note: $200 \%$ of material used in transcription assay was deproteinized and analyzed on agarose gel (ethidium bromide stained). 


\section{Discussion}

As cells divide chromatin oscillates between the states of highly condensed metaphase chromosomes, complete disassembly during replication and the rather accessible chromatin structure in interphase nuclei. The major challenge for each cell is to maintain the functionality of specialized chromatin structures throughout cell divisions. Of course, maintenance is not possible in a literal sense. During DNA replication chromatin structure is disassembled at least once to allow the passage of the replication machinery. Therefore, the re-establishment of these specific chromatin structures is the key process for each cell to preserve its genomic integrity and thus its cellular identity. Thereby chromatin assembly following DNA replication (replication-coupled [RC] assembly) is complemented by a second pathway that fulfills all histone deposition on DNA independent of DNA synthesis (replicationindependent [RI] assembly). A long-standing question is how these pathways contribute to the establishment and/or maintenance of functionally distinct chromatin regions and thus epigenetic phenomena.

In this study I could demonstrate that these two different chromatin assembly pathways generate structurally, biochemically and functionally different chromatin species. Whereas the RI assembled chromatin exhibited 'active' methylation marks and proved to be transcriptionally competent the replication-coupled pathway resulted in largely unmethylated and trancriptionally inactive chromatin. Table 4.1 gives a brief overview of the features for both chromatin assembly pathways observed in this study.

\subsection{Assembly pathways create distinct chromatin structures}

Topology studies on both chromatin species derived either by assembly on dsDNA (RI pathway) or ssDNA (RC pathway) revealed that both species were equally saturated with nucleosomes. The topology of the used circular templates also suggested that a similar degree of supercoiling is introduced on both templates during assembly. Despite these comparable features, the dsDNA-derived chromatin appeared to be of a higher density than the ssDNA-derived chromatin when analyzed by 
sucrose gradient centrifugation. AFM studies on fixed chromatin also revealed obvious structural differences. However, these structural differences did not fully explain the observed sedimentation profile of soluble chromatin. At this point it cannot be excluded that this is due to technical problems or changes introduced upon fixation. The found differences of chromatin sedimentation profiles in sucrose density gradients either indicate a higher degree of compaction induced by RI chromatin assembly or a higher molecular weight caused by stable association of auxiliary factors to that chromatin species.

Table 4.1 | Summarized properties of chromatin species derived by replication-coupled (RC) or replication-independent (RI) chromatin assembly.

\begin{tabular}{|c|c|c|}
\hline & RC pathway & RI pathway \\
\hline Chromatin shape (AFM) & spherical & rod-shaped \\
\hline $\begin{array}{l}\text { Relative sedimentation } \\
\text { profile (sucrose gradients) }\end{array}$ & low sucrose concentrations & high sucrose concentrations \\
\hline Histones & B4 (link & $\begin{array}{l}2 \\
\mathrm{~A} \\
\mathrm{~B} \\
\text { histone) }\end{array}$ \\
\hline \multirow[t]{2}{*}{ Histone variants } & \multicolumn{2}{|c|}{$\begin{array}{c}\text { H2A.Z } \\
\text { H2A.X-F1/F2 }\end{array}$} \\
\hline & & H3.3 \\
\hline \multirow[t]{8}{*}{ Histone modifications } & & H3K4me1 \\
\hline & & $\mathrm{H} 3 \mathrm{~K} 4 \mathrm{me} 2$ \\
\hline & & $\mathrm{H} 3 \mathrm{~K} 4 \mathrm{me} 3$ \\
\hline & & H4K20me1 \\
\hline & \multicolumn{2}{|c|}{ H3K9me1 (low levels) } \\
\hline & \\
\hline & $\mathrm{H} 4 \mathrm{~K} 5 \mathrm{ac}$ & $\mathrm{H} 4 \mathrm{~K} 5 \mathrm{ac} \downarrow$ \\
\hline & $\mathrm{H} 4 \mathrm{~K} 12 \mathrm{ac}$ & $\mathrm{H} 4 \mathrm{~K} 12 \mathrm{ac} \downarrow$ \\
\hline Transcriptional activity & silenced & active \\
\hline
\end{tabular}

Indeed, mass spectrometry analysis of both chromatin types identified more unique proteins associated with the dsDNA-derived chromatin (65 proteins) than with ssDNA-derived chromatin (25 proteins). However, considering the large number of identified proteins ( $>1,200$ proteins) these are marginal differences. Moreover, the relative amount of a certain protein cannot be determined with the mass spectrometry set-up used. 


\subsubsection{Influence of histone acetylation and methylation on chromatin structure}

It is more likely that the posttranslational histone modifications present on the assembled chromatin play a role in defining chromatin structure. Histone modifications potentially direct chromatin structure either by changing inter/intranucleosomal contacts or by recruiting proteins that bind to these marks and mediate downstream effects. In particular histone acetylation has a profound impact on chromatin structure as it can neutralize charges and thereby cause decompaction of chromatin [55, 208-210]. Especially lysine acetylation within the $\mathrm{N}$-terminal region of histone $\mathrm{H} 4$ tails has been reported in this context [55, 209].

My analyses of global and specific H4 acetylation levels revealed that acetylation is reduced on chromatin assembled RI on dsDNA in comparison to the RC pathway on ssDNA. A study by Reinberg and colleagues demonstrated that low acetylation levels of core histones and incorporation of linker histone in recombinant chromatin templates lead to the highest degree of compaction [208]. By comparing the sucrose sedimentation profiles of hyper- and hypoacetylated chromatin they showed that hypoacetylated chromatin sediments at higher sucrose concentration and as judged from electron microscopy images is more compacted. In this context RI assembly seems to lead to a higher degree of compaction by reduced acetylation levels. Since histone deacetylases (HDACs) were identified in both chromatin samples, further studies using deacetylase inhibitors during chromatin assembly in the egg extract might be helpful to substantiate this hypothesis.

Besides differences in acetylation, I detected two major methylation marks, H4K20me1 and H3K4me(1/2/3), exclusively associated with the RI chromatin assembly on dsDNA. Direct structural changes initiated by methylation have not been observed so far and are rather unlikely to occur due to the physical and chemical properties of methyl marks [32]. A structural effect is rather mediated by proteins that bind methyl marks than by a direct effect of the methyl mark. It is thus conceivable that, besides the direct effect of hypoacetylation, H3K4 methylation and H4K20me1 influence chromatin structure by recruiting deacetylases or other effector proteins. The impact of methylation on chromatin structure is supported by the fact that chromatin assembled on dsDNA in presence of $\mathrm{SAH}$, a potent inhibitor of methylation, more closely resembled the structures observed for the unmethylated and presumably less compacted ssDNA-derived chromatin. 
Indeed, methylation could be the cause for hypoacetylation on RI assembled chromatin. Histone methylation is read by various proteins containing methyl-binding motifs like PHD fingers, chromo domains and MBT domains [57]. Many of these readers are part of larger complexes containing remodeling activity or enzymatic activity like acetylation and deacetylation [153, 211, 212]. Human L3MBTL1, an MBT-containing protein, recruits HDACs and thus leads to hypoacetylation of chromatin [153, 213-215]. L3MBTL1 was also shown to compact chromatin in vitro in dependence on H4K20me1 [215]. This reflects very well how histone modifications can act as a docking platform to recruit effector proteins that mediate downstream effects like structural changes.

Since RI assembly mainly occurs outside of S-phase and considering that RI chromatin assembly resulted in a higher degree of compaction, this pathway could contribute to chromosome compaction outside of S-phase and in particular during Mphase. This assumption is supported by several studies demonstrating that H4K20me1 is essential for mitotic entry and marks mitotic chromosomes [36, 44, 188, 216, 217]. Further, knock-out of the responsible H4K20 monomethylase PR-Set7 in mice is embryonic lethal due to massive DNA damage and improper mitotic chromosome condensation [217].

\subsection{Active histone methylations as a result of RI chromatin assembly}

\subsubsection{Cell cycle dynamics of H4K20 monomethylation}

In this study I could show that H4K20me1 is tightly coupled to chromatin assembly on dsDNA during the RI assembly pathway. The methylation itself was incorporated towards the end of chromatin assembly. Further time courses of RC chromatin assembly on ssDNA essentially proved that this methylation is not associated with DNA synthesis and thus replication. This difference in H4 methylation between both chromatin assembly pathways is accompanied by opposing $\mathrm{H} 4$ acetylation levels. H4 acetylation was strongly reduced on the dsDNA-derived chromatin sample arguing for an enhanced recruitment of HDACs. In contrast, the H4 acetylation levels were much higher on ssDNA-derived chromatin, which was void of H4K20me1. 
My study demonstrated that newly deposited H4 histones are not methylated on K20 during chromatin assembly coupled to DNA replication. Instead, my findings strongly support the idea that RI chromatin assembly outside of S-phase mediates H4K20me1 as well as pronounced deacetylation of $\mathrm{H} 4$ histones.

In a recent study H4K20me1 was identified as a novel histone modification on chromatin after assembly. The experiments were performed using Drosophila embryonic extracts to assemble chromatin in vitro and histone modifications were analyzed by mass spectrometry. The authors showed that H4K20 is monomethylated by PR-Set7 shortly after assembly [153]. This modification then recruits deacetylases to remove the present acetylation marks on $\mathrm{H} 4$ (H4K5ac and H4K12ac), a process described before as chromatin maturation [99]. Even though the authors claim that this maturation process initiated by PR-Set7 is a general feature of chromatin assembly, their observations are only based on experiments using dsDNA fragments but not ssDNA. Indeed, my experiments revealed that only dsDNA-derived chromatin but not ssDNA-derived chromatin contains H4K20me1. The opposing acetylation levels of both chromatin species further substantiate that the PR-Set7 mediated maturation process is not associated with both assembly pathways.

In general, the data on the temporal and spatial distribution of H4K20 monomethylation in the literature is contradicting. Previous studies had suggested that PR-Set7 also mediates H4K20 monomethylation during S-phase [188, 218]. Growing evidence, however, suggests that H4K20 methylation is a cell cycle regulated histone modification [53]. Metabolic labeling of synchronized HeLa cells demonstrated that newly synthesized H4 that is deposited during S-phase is not de novo methylated on H4K20 after replication [45]. Actually, H4K20me1 first appeared at the G2/M transition and most of it was subsequently di- and trimethylated within two to three cell cycles. I could show that histones present in the stockpile of the Xenopus egg are preacetylated on H4 but not methylated (see also [194]), which verified that de novo methylation of H4K20 is occurring during RI assembly in the egg extract. Since H4K20me1/2/3 persist through several cell cycles, previous studies connecting H4K20me1 to S-phase presumably identified 'old' H4K20me1 instead of a de novo H4 methylation during S-phase.

The coupling of H4K20 methylation to the RI assembly pathway could potentially represesent a way to regulate and modulate the genome outside of S-phase. Moreover, one could interpret the oscillating levels of H4K20me1 not as cell cycle regulated but 
as a regulator of cell cycle progression. Cells depleted of H4K20me1 arrest at G2phase and do not enter M-phase [188]. On the contrary, overexpression of PR-Set7 or a non-degradable PR-Set7 results in re-replication of DNA during G2-arrest and causes premature compaction of chromatin [219, 220].

\subsubsection{Regulation of H4K20me1 and PR-Set7 activity}

Even though PR-Set7 and H4K20me1 are linked to RI-assembly my findings argue against a recruitment of PR-Set7 by HIRA, H3.3 or the preceding H3K4 methylation to chromatin. However, that does not exclude that other histone modifications or interacting proteins might play a role in PR-Set7 recruitment. DNA-binding factors or proteins that bind the preceding $\mathrm{H} 3 \mathrm{~K} 4$ methylation could target PR-Set7 to RI chromatin assembly. Therefore, the question remaining is how PR-Set7 is targeted to the RI chromatin assembly process or what prevents H4K20 methylation by PR-Set7 during RC assembly?

Several studies reported on PR-Set7 localization to replication foci and an interaction of PR-Set7 with PCNA thereby connecting PR-Set7 and H4K20me1 to S-phase [218, 221, 222]. However, none of these studies actually demonstrated that $\mathrm{H} 4$ is the substrate in this context. New studies revealed that binding of PR-Set7 to PCNA induces degradation of PR-Set7 and thereby promotes cell cycle progression [219, 223-225]. This mechanism could contribute to the oscillating PR-Set7 and thus H4K20me1 levels during the cell cycle. Interestingly, the amount of PCNA present in Xenopus laevis eggs is $4 \times 10^{5}$ higher than the amount of PCNA present in somatic cells [226]. Therefore, PCNA could be a factor in the egg extract that sequesters PRSet7 and therefore prevents ubiquitous methylation. Indirectly, this is supported by my findings that ssDNA-derived chromatin is accessible for methylation by recombinant PR-Set7 after sucrose gradient centrifugation; i.e., removal of unbound proteins. Notably, I detected PCNA in both assembly pathways by mass spectrometry analysis but interaction with PR-Set7 in the extract was not tested so far due to lack of specific antibodies. 


\subsubsection{H3K4me and H4K20me1 as major determinants of transcriptional activity}

One of the most exciting findings of this study was the direct connection of the RI assembly pathway with H3.3 incorporation, H3K4 methylation and transcriptional activity. Several studies have shown before that H3.3 is a replication-independent histone and bound by HIRA [16, 20, 123, 124]. On the contrary, all links between H3.3, H3K4me3 and transcriptionally active genes were derived from chromatin immunoprecipitation (ChIP) data or immunofluorescence studies [114, 115, 227]. My findings on H3.3 incorporation during RI assembly and a HIRA-associated H3K4 methyltransferase activity finally connect both observations. Moreover, the transcriptional analyses demonstrated that only chromatin assembled by the RI pathway and carrying $\mathrm{H} 3 \mathrm{~K} 4 \mathrm{me}$ and $\mathrm{H} 4 \mathrm{~K} 20 \mathrm{me} 1$ is in a transcriptionally primed state. Blocking methylation with SAH during assembly resulted in a strong decrease in transcription, which demonstrated the major contribution of methylation to the transcriptional competency. Still, from this experiment it could not be deduced whether both methyl marks or just one of them is important for transcriptional activation. It is however conceivable that both methylation marks contribute to transcription.

All three states of $\mathrm{H} 3 \mathrm{~K} 4$ methylation (me1/2/3) have been linked to transcriptional activation [202]. How H3K4me mechanistically mediates transcription is not completely understood. In my studies I detected a subunit of the basal transcription factor TFIID exclusively associated with the RI assembly pathway and thus H3K4me. TFIID is known to directly bind H3K4me3 [228], which presumably results in enhanced recruitment of other transcription factors.

Unlike H3K4 methylation, which has been undoubtedly linked to transcriptional activation, the findings on H4K20 methylation and in particular H4K20me1 remain controversial. Analyses are hampered by the fact that the majority of this modification is turned into $\mathrm{H} 4 \mathrm{~K} 20 \mathrm{me} 2 / 3$ throughout the cell cycle $[45,46]$. Mounting evidence suggests that $\mathrm{H} 4 \mathrm{~K} 20 \mathrm{~m} 1$, me2 and me3 are functionally distinct.

H4K20me1 has been linked to gene repression in several studies [44, 189, 213, 229]. They also revealed that depletion of PR-Set7 and thus H4K20me1 affects H4K20me2/3 levels [44]. Gene repression thus cannot be solely attributed to H4K20me1 but could be a secondary effect by its turnover into H4K20me2/3. 
Recent progress in ChIP sequencing technology and other studies revealed that H4K20mel is associated with active gene transcription and sharply peaks at active genes [230-233]. Here, localization of H4K20me1 and H3K4me1/2 overlap. Whether these modifications are uniformly distributed on chromatin assembled in Xenopus egg extract or only co-localize for example at the inserted transcription cassette remains unknown. Considering that PR-Set7 does not interact directly with HIRA they might indeed show an irregular distribution on the template.

My findings support that chromatin carrying $\mathrm{H} 3 \mathrm{~K} 4 \mathrm{mel} / 2 / 3$ and $\mathrm{H} 4 \mathrm{~K} 20 \mathrm{mel}$ is transcriptional active. From the literature it can be deduced that not only H3K4me but also H4K20me1 can be a determinant of active gene transcription. The here described chromatin assembly system in Xenopus egg extract might be especially suited to tackle the question of H4K20me1 contribution to transcription. Thereby, depletion studies with PR-Set7 specific antibodies might help to elucidate the contribution of H4K20me1 to transcription in the egg extract assembly system.

\subsection{Histone H3.3 marks RI assembly whereas $\mathrm{H} 2 \mathrm{~A}$ variants are incorporated in both pathways}

\subsubsection{Histone variants can be incorporated during both pathways}

Besides the structural analysis and the analysis of histone modifications, the comparison of histone proteins revealed that $\mathrm{H} 2 \mathrm{~A}$ histone variants are incorporated during both assembly pathways but not H3.3. This challenges the current belief that histone variants are exclusively incorporated during RI assembly due to vast amounts of canonical histones that compete with them during S-phase. While some histone chaperones like HIRA might be exclusive for RI assembly and others like CAF-1 for $\mathrm{RC}$ assembly, their interaction with less specialized chaperones potentially is important to fulfill assembly.

I could show that the histone variant H3.3 is exclusively incorporated during assembly on dsDNA and not on ssDNA/chromatin. Add-on experiments confirmed this observation as $\mathrm{H} 3.3-\mathrm{H} 4$ complexes were preferentially incorporated into chromatin assembled RI on dsDNA. However, mass spectrometry analysis revealed that besides $\mathrm{H} 3.3$ also the canonical histone $\mathrm{H} 3$ (H3.2 in X. laevis) is incorporated during RI assembly. This stands in contrast to a study suggesting that HIRA 
exclusively utilizes H3.3 during RI assembly [20]. Moreover, biochemical and structural analyses suggest that HIRA is complexed with a H3-H4 dimer and not a tetramer, thereby excluding that $\mathrm{H} 3$ and $\mathrm{H} 3.3$ are bound simultaneously in one complex [20, 101, 234].

It is not clear whether HIRA directly binds to the H3-H4 dimer. Indeed, it appears as if the Asf1 chaperone supplies HIRA with H3-H4 dimers by directly binding to it [20, 98, 234]. Asf1 is considered a general histone 'feeder' as it also interacts with the RC assembly process in particular CAF-1 $[102,103]$. Still there is no biochemical or structural data available to give more insights into the specificity of Asf1 for H3 vs. H3.3. The published Asf1 structures show that Asf1 binds the C-terminal region of H3, which is identical in $\mathrm{H} 3$ and H3.3 $[235,236]$. It is thus possible that Asf1 and HIRA cooperatively deposit two H3-H4 dimers onto DNA with HIRA binding H3.3 and Asfl either H3 or H3.3. The described Asfl chaperone in Xenopus laevis was shown to promote RI assembly through interaction with HIRA but not RC assembly mediated by CAF-1 [98]. My results imply that this HIRA-Asf1 complex mediates incorporation of both $\mathrm{H} 3.3$ and H3 during RI assembly whereas during RC assembly by CAF-1 virtually no H3.3 is incorporated.

Besides HIRA that was demonstrated to be a critical factor for RI assembly in Xenopus laevis egg extracts [97], I detected the DEK oncogene exclusively during RI assembly. DEK was recently shown to be a H3.3 histone chaperone in Drosophila [119]. Moreover, Rbbp4/RbAp48 which is another multifunctional H3-H4 chaperone like Asf1, was detected in both pathways [63]. Whether the functions of DEK and RbAp48 during RI and RC chromatin assembly are similar to that of HIRA and Asf1 remains unclear.

Besides H3.3, my results showed that two H2A variants are incorporated during both assembly pathways. Two egg-specific H2A.X isoforms (H2A.X-F1/F2) and the H2A.Z histone were found. H2A.X-F1/F2 were shown to be the major H2A variants in Xenopus laevis eggs [237, 238]. The H2A.X-F1/2 variants are specialized forms of H2A.X that are incorporated independent of exogenous DNA damage in early embryos [238]. This stands in contrast to the known DNA damage response functions of conventional H2A.X [239]. The role of H2A.X-F1/2 in these early developmental stages remains unclear.

Presence of H2A.Z in both assembly pathways was confirmed by mass spectrometry and immunoblots. This special $\mathrm{H} 2 \mathrm{~A}$ variant is implicated in gene transcription as it is 
predominantly found at promoter regions [25, 231]. H2A-H2B deposition has been associated with the FACT complex that I identified in both assembly pathways. This finding supports studies that demonstrate that FACT is not only involved in eviction and deposition of H2A-H2B during transcription (i.e., RI assembly; [174]) but also mediates deposition coupled to DNA replication [111, 113, 175].

Although the immediate functions of H2A.Z and H2A.X-F1/F2 remain unknown in each assembly pathway, my observations prove that in contrast to $\mathrm{H} 3$ histone $\mathrm{H} 2 \mathrm{~A}$ variants are incorporated not only replication-independent but also during DNA replication in Xenopus laevis. Since both H2A variants are more abundant than canonical H2A in the egg, it is questionable whether this observation is transferable to other organisms or instead represents a unique feature of the egg and early embryonic development in Xenopus laevis.

\subsubsection{Combinations of histone variants and unique proteins potentially change chromatin stability}

Since the depletion of methylation marks on dsDNA-derived chromatin by SAH did not lead to a complete loss of transcription other features of the dsDNA/chromatin must contribute to its transcriptional competence. I believe that the unique set of incorporated histone variants and associated proteins thereby play a role. My experiments revealed that only during RI assembly H3.3 and H2A.Z are incorporated together into chromatin. Nucleosomes bearing that combination of histone variants are extremely instable and enriched at active promoters [21, 182]. Presumably, the inherent instability of H2A.Z and H3.3 containing nucleosomes can facilitate their eviction during transcription and thus contribute to the transcriptional activity of chromatin derived by RI assembly. In particular the FACT complex evicts H2A-H2B and was shown to mediate exchange of H2A with H2A.X but so far not with H2A.Z [187]. Recent observations even suggest that FACT binds to H3-H4 complexes and not only H2A-H2B [240]. However, it remains to be seen whether FACT shows affinity towards H3.3/H2A.Z nucleosomes.

Whereas FACT and H2A.Z were present in both chromatin species it might be the unique combination with $\mathrm{H} 3.3$ in the dsDNA/chromatin that promotes transcription besides the discussed methylation marks. 


\subsection{Physiological roles of chromatin assembly pathways}

\subsubsection{Implications of replication-independent assembly in fertilization}

The Xenopus laevis eggs used for egg extract preparation are arrested at meiotic metaphase II. The resumption of meiosis is naturally triggered by fertilization and thus paternal pronucleus formation, which is a prerequisite for gamete fusion [241]. Upon fertilization sperm chromatin is remodeled, as its major components are sperm specific proteins like protamines but not histones. This remodeling process is thought to closely resemble RI assembly because HIRA is essential for paternal pronucleus formation [123-125]. Moreover, H3.3 incorporation is restricted to the paternal genome before the first round of replication [124]. I was thus wondering whether remodeled Xenopus sperm chromatin would carry the same modifications as observed for the dsDNA-derived chromatin. In my assays I detected H3K4 methylation but strikingly no H4K20me1 on decondensed sperm chromatin. Whether this methylation is connected to a transcriptional activation could not be analyzed. Notably, in mammals the paternal pronucleus was shown to exhibit a 4-5 times higher transcriptional activity than the maternal pronucleus and this transcriptional activation persisted even when DNA replication was blocked at the 1-cell stage [242]. The biological relevance of paternal gene transcription in the pronucleus was not elucidated so far. My results suggest that the RI chromatin assembly machinery and thus HIRA and the detected H3K4 methyltransferase could mediate that transcriptional burst in the male pronucleus.

Whether the same transcriptional activation exists in Xenopus laevis upon fertilization has to be subject of future research. Indeed, Xenopus sperm decondensation might not be a suitable system to investigate the impact of RI assembly (and HIRA) on pronucleus formation, since Xenopus sperm still contains reasonable amounts of H3H4 histone but is depleted of H2A-H2B and linker histone H1 [243]. Hence, sperm decondensation mainly involves deposition of $\mathrm{H} 2 \mathrm{~A}-\mathrm{H} 2 \mathrm{~B}$, which is essentially mediated by nucleoplasmin and not HIRA in Xenopus laevis [122, 176]. 


\subsubsection{Is all newly replicated chromatin silenced?}

Strikingly no major modification sites existed at all after RC chromatin assembly on ssDNA. Of course it is questionable how well this represents the in vivo situation. The Xenopus egg extract assembly system has one drawback. It does not mediate replication through a chromatin template. Thus the lack of modifications might actually be a result of the used template that is missing any modifications/variants before RC assembly takes place. My observations on RC assembly implicate that the distribution of the old (parental) and newly synthesized histones during replication have to be the major determinants of modifications present after replication because DNA-synthesis and chromatin assembly itself did not introduce significant modulations on chromatin. In particular the fate of H3-H4 complexes is highly debated in the literature. Since early studies showed that H3-H4 tetramers are very stable and are first deposited onto DNA followed by H2A-H2B dimers, it was assumed that $\mathrm{H} 3-\mathrm{H} 4$ tetramers are transmitted as an entity $[64,65]$. A proposed model suggests that histone modifications are thereby copied from 'old' neighboring nucleosomes to new ones [2]. However, another attractive model is the break-up into $\mathrm{H} 3-\mathrm{H} 4$ dimers as those in combination with a new H3-H4 dimer could serve as templates for the 'correct' modification on new histones [20, 107]. This model is similar to the reported transmission of DNA methylation during replication. Here, mediated by the semiconservative mode of replication each daughter strand becomes hemimethylated. The hemimethylated DNA is preferentially recognized by DNA methyltransferases (Dnmt1) that then fully methylate DNA, thereby restoring this modification [244].

Notably, a recent study claims that significant amounts of $\mathrm{H} 3.3-\mathrm{H} 4$ tetramers split into dimers during replication whereas the majority of canonical H3-H4 tetramers stay intact [180]. This would implicate that the transmission of H3-nucleosomes is different from the one of H3.3-nucleosomes.

Interestingly, all connections made so far between the replication machinery and histone modifications point to repressive marks and thus heterochromatin. For instance CAF-1 the key player in histone deposition during replication is known to interact with HP1 $\alpha$ that in turn binds to $\mathrm{H} 3 \mathrm{~K} 9 \mathrm{me} 3[245,246]$. Through its interaction with methyltransferases HP1 is thought to mediate installation of this repressive mark after replication [107]. Indeed, depletion of CAF-1 leads to abnormal heterochromatin 
structures in mouse embryonic cells and a decrease of H3K9 methylation in Drosophila [109, 247].

Certainly, chromatin assembly on ssDNA represents a minimal approach to mimic RC assembly during DNA replication. Nevertheless, the observed features of low methylation levels and repressed transcription could indeed reflect the properties of the very basal RC chromatin assembly process without a bias towards preexisting modifications.

\subsubsection{HIRA and RI assembly as the key players in resetting transcriptional competency}

A general conclusion from the side-by-side comparison of both assembly pathways is that during the replication-coupled pathway the immediate local environment must determine the presence of modifications in a given genomic region. My experiments indicate that the replication machinery itself does not direct modifications. In contrast, factors involved in RI independent assembly interact with methyltransferases that directly influence the transcriptional competence. To prevent that these active marks are gradually lost with each cell division the RI assembly pathway could be the crucial mechanism to re-establish the activation of specific genomic regions. Especially the H3K4 methyltransferase that I detected in combination with HIRA could prevent that the $\mathrm{H} 3 \mathrm{~K} 4 \mathrm{me}$ mark is diluted out through successive cell cycles. Here, more research is necessary to transfer this observation to other systems and identify the involved methyltransferase(s). Overall, I believe that the specific resetting of transcriptional competency after cell division by RI assembly is more reasonable for cell survival and metabolism than an uncontrolled burst in gene transcription. HIRA targeting has not been elucidated in the literature. One possibility of specific recruitment might be HIRA's ability to bind H3.3 that is still present at certain sites after replication. Assuming that $\mathrm{H} 3.3-\mathrm{H} 4$ tetramers are preferentially split during replication but not $\mathrm{H} 3-\mathrm{H} 4$ tetramers [180], HIRA recruitment could be enhanced by binding to these free dimers as HIRA does not bind to tetramers [20, 234]. Moreover, this suggests that both pathways are not as strictly separated from each other as noted by early studies [16]. 
Based on my studies and the available literature I hypothesize that RC chromatin assembly transmits repressive marks whereas active marks are transmitted by the RI assembly pathway (Figure 4.1).

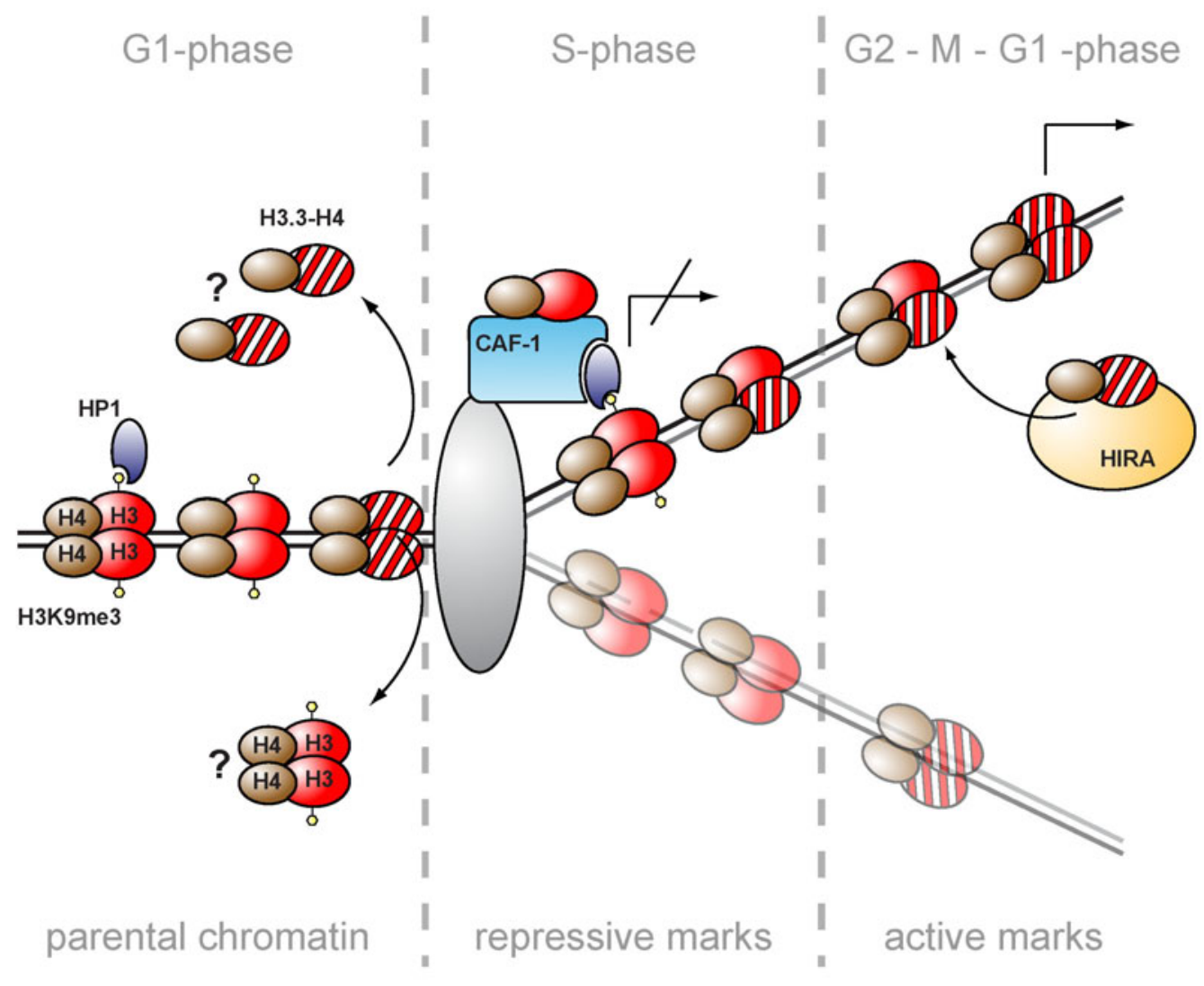

Figure 4.1 | Proposed model of transmission of repressive and active marks. The two chromatin assembly pathways mediated by the chaperones CAF-1 and HIRA as well as the fate of H3-H4 complexes during cell cycle phases is depicted. Before DNA-replication certain functional states of paternal chromatin exist like silenced domains containing HP1 and H3K9me3 and active domains marked by presence of H3.3. Chromatin is transiently disrupted during S-phase by the replication machinery (grey ellipse). CAF-1 associates with that machinery via interaction with PCNA. Through interaction of CAF-1 with HP1 binding to the repressive $\mathrm{H} 3 \mathrm{~K} 9 \mathrm{me} 3$ mark is mediated and potentially extended to neighboring nucleosomes. RI assembly presumably takes place outside of S-phase by exchange/deposition of H3.3-H4 dimers by HIRA. Association of HIRA with methyltransferases can thereby mediate active marks like H3K4 methylation (not shown). 


\section{$5 \quad$ Summary and conclusions}

Our current understanding of how cells preserve their cellular identity by assembly and modulation of chromatin structure is largely based on the analyses of single events like histone incorporation, histone modifications or gene activity. In higher organisms two chromatin assembly pathways have evolved that ensure DNA packaging into nucleosomal structures at virtually every time point during the cell cycle: The replication-coupled (RC) and the replication-independent (RI) chromatin assembly pathways. Little is known about how the use of a distinct assembly pathway is connected to the observed variations in chromatin function within a single genome. Using a cell-free assembly system derived from Xenopus laevis egg extracts I performed a side-by-side analysis of the two assembly pathways. This analysis revealed that the chromatin species derived by these pathways differ from each other. Apparently, RI chromatin assembly mediates a higher degree of chromatin compaction and transcriptional competence through implementation of active methylation marks on H3K4 and H4K20. RI assembly thereby utilizes the H3.3 histone variant and associates with an $\mathrm{H} 3 \mathrm{~K} 4$ methyltransferase. Both facts presumable contribute to the observed transcriptional activation. In contrast, chromatin assembled by RC assembly is transcriptionally inert and does not contain active methyl marks implying that the replication machinery does not directly introduce histone modifications. Instead, the used experimental set-up indicated that the distribution of parental histones during replication must be the major determinant of chromatin modulation during the RC pathway.

Based on these considerations, I propose that replication-coupled assembly mediates transmission of repressive marks whereas replication-independent assembly transmits active histone modifications. As RI assembly mainly occurs outside of S-phase it might represent a mechanism that resets the activation of tissue-specific genes after replication thereby preserving cellular identity. 


\section{References}

1. Waddington, C.H., Epigenetics and evolution. Symp Soc Exp Biol, 1953. 7: p. 186-199.

2. Allis, C.D., T. Jenuwein, and D. Reinberg, Epigenetics2007, Cold Spring Harbor: Cold Spring Harbor Laboratory Press.

3. Kornberg, R.D., Chromatin structure: a repeating unit of histones and DNA. Science, 1974. 184(139): p. 868-71.

4. Olins, A.L. and D.E. Olins, Spheroid chromatin units (v bodies). Science, 1974. 183(4122): p. 330-2.

5. Luger, K., et al., Crystal structure of the nucleosome core particle at 2.8 A resolution. Nature, 1997. 389(6648): p. 251-60.

6. Davey, C.A., et al., Solvent mediated interactions in the structure of the nucleosome core particle at 1.9 a resolution. J Mol Biol, 2002. 319(5): p. 1097-113.

7. Felsenfeld, G. and M. Groudine, Controlling the double helix. Nature, 2003. 421(6921): p. 448-53.

8. Widom, J., A relationship between the helical twist of DNA and the ordered positioning of nucleosomes in all eukaryotic cells. Proc Natl Acad Sci USA, 1992. 89(3): p. 1095-9.

9. Huynh, V.A., P.J. Robinson, and D. Rhodes, A method for the in vitro reconstitution of a defined "30 $\mathrm{nm}$ " chromatin fibre containing stoichiometric amounts of the linker histone. J Mol Biol, 2005. 345(5): p. 957-68.

10. Schalch, T., et al., X-ray structure of a tetranucleosome and its implications for the chromatin fibre. Nature, 2005. 436(7047): p. 138-41.

11. Heitz, E., Das Heterochromatin der Moose. I. Jahrb Wiss Bot, 1928. 69: p. 762-819.

12. Elgin, S. and S. Grewal, Heterochromatin: silence is golden. Curr Biol, 2003. 13(23): p. R895-8.

13. Avner, P. and E. Heard, X-chromosome inactivation: counting, choice and initiation. Nat Rev Genet, 2001. 2(1): p. 59-67.

14. Dillon, N. and R. Festenstein, Unravelling heterochromatin: competition between positive and negative factors regulates accessibility. Trends Genet, 2002. 18(5): p. 252-8.

15. Filion, G.J., et al., Systematic protein location mapping reveals five principal chromatin types in Drosophila cells. Cell, 2010. 143(2): p. 212-24.

16. Ahmad, K. and S. Henikoff, The histone variant H3.3 marks active chromatin by replicationindependent nucleosome assembly. Mol Cell, 2002. 9(6): p. 1191-200.

17. Sullivan, K.F., M. Hechenberger, and K. Masri, Human CENP-A contains a histone H3 related histone fold domain that is required for targeting to the centromere. J Cell Biol, 1994. 127(3): p. 581-92.

18. Jin, J., et al., In and out: histone variant exchange in chromatin. Trends Biochem Sci, 2005. 30(12): p. 680-7.

19. Marzluff, W.F. and R.J. Duronio, Histone mRNA expression: multiple levels of cell cycle regulation and important developmental consequences. Curr Opin Cell Biol, 2002. 14(6): p. 692-9.

20. Tagami, H., et al., Histone H3.1 and H3.3 complexes mediate nucleosome assembly pathways dependent or independent of DNA synthesis. Cell, 2004. 116(1): p. 51-61.

21. Jin, C., et al., H3.3/H2A.Z double variant-containing nucleosomes mark 'nucleosome-free regions' of active promoters and other regulatory regions. Nat Genet, 2009. 41(8): p. 941-5.

22. Lewis, P.W., et al., Daxx is an H3.3-specific histone chaperone and cooperates with ATRX in replication-independent chromatin assembly at telomeres. Proc Natl Acad Sci U S A, 2010. 107(32): p. 14075-80.

23. Witt, O., W. Albig, and D. Doenecke, Testis-specific expression of a novel human H3 histone gene. Exp Cell Res, 1996. 229(2): p. 301-6.

24. Rogakou, E.P., et al., DNA double-stranded breaks induce histone H2AX phosphorylation on serine 139. J Biol Chem, 1998. 273(10): p. 5858-68.

25. Meneghini, M.D., M. Wu, and H.D. Madhani, Conserved histone variant H2A.Z protects euchromatin from the ectopic spread of silent heterochromatin. Cell, 2003. 112(5): p. 725-36.

26. Chadwick, B.P., C.M. Valley, and H.F. Willard, Histone variant macroH2A contains two distinct macrochromatin domains capable of directing macroH2A to the inactive $X$ chromosome. Nucleic Acids Res, 2001. 29(13): p. 2699-705. 
27. Pehrson, J.R. and V.A. Fried, MacroH2A, a core histone containing a large nonhistone region. Science, 1992. 257(5075): p. 1398-400.

28. Govin, J., et al., Pericentric heterochromatin reprogramming by new histone variants during mouse spermiogenesis. J Cell Biol, 2007. 176(3): p. 283-94.

29. Chadwick, B.P. and H.F. Willard, A novel chromatin protein, distantly related to histone H2A, is largely excluded from the inactive X chromosome. J Cell Biol, 2001. 152(2): p. 375-84.

30. Trostle-Weige, P.K., et al., Isolation and characterization of TH2A, a germ cell-specific variant of histone $2 A$ in rat testis. J Biol Chem, 1982. 257(10): p. 5560-7.

31. Brock, W.A., P.K. Trostle, and M.L. Meistrich, Meiotic synthesis of testis histones in the rat. Proc Natl Acad Sci U S A, 1980. 77(1): p. 371-5.

32. Kouzarides, T., Chromatin modifications and their function. Cell, 2007. 128(4): p. 693-705.

33. Rea, S., et al., Regulation of chromatin structure by site-specific histone H3 methyltransferases. Nature, 2000. 406(6796): p. 593-9.

34. Pradhan, S., et al., SET7/9 mediated methylation of non-histone proteins in mammalian cells. Epigenetics, 2009. 4(6): p. 383-7.

35. Collins, R.E., et al., In vitro and in vivo analyses of a Phe/Tyr switch controlling product specificity of histone lysine methyltransferases. J Biol Chem, 2005. 280(7): p. 5563-70.

36. Fang, J., et al., Purification and functional characterization of SET8, a nucleosomal histone H4-lysine 20-specific methyltransferase. Curr Biol, 2002. 12(13): p. 1086-99.

37. Xiao, B., et al., Specificity and mechanism of the histone methyltransferase Pr-Set7. Genes Dev, 2005. 19(12): p. 1444-54.

38. DeLange, R.J., et al., Calf and pea histone IV. II. The complete amino acid sequence of calf thymus histone IV; presence of epsilon- $N$-acetyllysine. J Biol Chem, 1969. 244(2): p. 319-34.

39. Nishioka, K., et al., PR-Set7 is a nucleosome-specific methyltransferase that modifies lysine 20 of histone $H 4$ and is associated with silent chromatin. Mol Cell, 2002. 9(6): p. 1201-13.

40. Couture, J.F., et al., Structural and functional analysis of SET8, a histone H4 Lys-20 methyltransferase. Genes Dev, 2005. 19(12): p. 1455-65.

41. Yin, Y., et al., SET8 recognizes the sequence RHRK2OVLRDN within the $N$ terminus of histone H4 and mono-methylates lysine 20. J Biol Chem, 2005. 280(34): p. 30025-31.

42. Schotta, G., et al., A silencing pathway to induce H3-K9 and H4-K20 trimethylation at constitutive heterochromatin. Genes Dev, 2004. 18(11): p. 1251-62.

43. Sanders, S.L., et al., Methylation of histone H4 lysine 20 controls recruitment of Crb2 to sites of DNA damage. Cell, 2004. 119(5): p. 603-14.

44. Karachentsev, D., et al., PR-Set7-dependent methylation of histone H4 Lys 20 functions in repression of gene expression and is essential for mitosis. Genes Dev, 2005. 19(4): p. 431-5.

45. Pesavento, J.J., et al., Certain and progressive methylation of histone H4 at lysine 20 during the cell cycle. Mol Cell Biol, 2008. 28(1): p. 468-86.

46. Yang, H., et al., Preferential dimethylation of histone H4 lysine 20 by Suv4-20. J Biol Chem, 2008. 283(18): p. 12085-92.

47. Brownell, J.E., et al., Tetrahymena histone acetyltransferase A: a homolog to yeast Gcn5p linking histone acetylation to gene activation. Cell, 1996. 84(6): p. 843-51.

48. Taunton, J., C.A. Hassig, and S.L. Schreiber, A mammalian histone deacetylase related to the yeast transcriptional regulator Rpd3p. Science, 1996. 272(5260): p. 408-11.

49. Shahbazian, M.D. and M. Grunstein, Functions of site-specific histone acetylation and deacetylation. Annu Rev Biochem, 2007. 76: p. 75-100.

50. Shi, Y., et al., Histone demethylation mediated by the nuclear amine oxidase homolog LSD1. Cell, 2004. 119(7): p. 941-53.

51. Tsukada, Y., et al., Histone demethylation by a family of JmjC domain-containing proteins. Nature, 2006. 439(7078): p. 811-6.

52. Allfrey, V.G. and A.E. Mirsky, Structural Modifications of Histones and their Possible Role in the Regulation of RNA Synthesis. Science, 1964. 144(3618): p. 559.

53. Yang, H. and C.A. Mizzen, The multiple facets of histone H4-lysine 20 methylation. Biochem Cell Biol, 2009. 87(1): p. 151-61.

54. Dormann, H.L., Regulation of heterochromatin protein 1 by phosphorylation of histone H3 and the HP1 hinge domain, in Laboratory of Chromatin Biology and Epigenetics2009, Rockefeller University: New York.

55. Shogren-Knaak, M., et al., Histone H4-K16 acetylation controls chromatin structure and protein interactions. Science, 2006. 311(5762): p. 844-7.

56. Fischle, W., Y. Wang, and C.D. Allis, Histone and chromatin cross-talk. Curr Opin Cell Biol, 2003. 15(2): p. 172-83. 
57. Daniel, J.A., M.G. Pray-Grant, and P.A. Grant, Effector proteins for methylated histones: an expanding family. Cell Cycle, 2005. 4(7): p. 919-26.

58. Becker, P.B. and W. Horz, ATP-dependent nucleosome remodeling. Annu Rev Biochem, 2002. 71: p. 247-73.

59. Fry, C.J. and C.L. Peterson, Chromatin remodeling enzymes: who's on first? Curr Biol, 2001. 11(5): p. R185-97.

60. Kingston, R.E. and G.J. Narlikar, ATP-dependent remodeling and acetylation as regulators of chromatin fluidity. Genes Dev, 1999. 13(18): p. 2339-52.

61. Cairns, B.R., Chromatin remodeling: insights and intrigue from single-molecule studies. Nat Struct Mol Biol, 2007. 14(11): p. 989-96.

62. Johnson, C.N., N.L. Adkins, and P. Georgel, Chromatin remodeling complexes: ATPdependent machines in action. Biochem Cell Biol, 2005. 83(4): p. 405-17.

63. De Koning, L., et al., Histone chaperones: an escort network regulating histone traffic. Nat Struct Mol Biol, 2007. 14(11): p. 997-1007.

64. Gruss, C., et al., Disruption of the nucleosomes at the replication fork. Embo J, 1993. 12(12): p. 4533-45.

65. Smith, S. and B. Stillman, Stepwise assembly of chromatin during DNA replication in vitro. Embo J, 1991. 10(4): p. 971-80.

66. Worcel, A., S. Han, and M.L. Wong, Assembly of newly replicated chromatin. Cell, 1978. 15(3): p. 969-77.

67. Das, C., J.K. Tyler, and M.E. Churchill, The histone shuffle: histone chaperones in an energetic dance. Trends Biochem Sci, 2010. 35(9): p. 476-89.

68. Dunleavy, E.M., et al., HJURP is a cell-cycle-dependent maintenance and deposition factor of CENP-A at centromeres. Cell, 2009. 137(3): p. 485-97.

69. Foltz, D.R., et al., Centromere-specific assembly of CENP-a nucleosomes is mediated by HJURP. Cell, 2009. 137(3): p. 472-84.

70. Luk, E., et al., Chz1, a nuclear chaperone for histone H2AZ. Mol Cell, 2007. 25(3): p. 357-68.

71. Lanzotti, D.J., et al., Developmental control of histone mRNA and dSLBP synthesis during Drosophila embryogenesis and the role of dSLBP in histone $m R N A$ 3' end processing in vivo. Mol Cell Biol, 2002. 22(7): p. 2267-82.

72. Meeks-Wagner, D. and L.H. Hartwell, Normal stoichiometry of histone dimer sets is necessary for high fidelity of mitotic chromosome transmission. Cell, 1986. 44(1): p. 43-52.

73. Sullivan, E., et al., Drosophila stem loop binding protein coordinates accumulation of mature histone mRNA with cell cycle progression. Genes Dev, 2001. 15(2): p. 173-87.

74. Ohlenbusch, H.H., et al., Selective dissociation of histones from calf thymus nucleoprotein. J Mol Biol, 1967. 25(2): p. 299-315.

75. Lowary, P.T. and J. Widom, New DNA sequence rules for high affinity binding to histone octamer and sequence-directed nucleosome positioning. J Mol Biol, 1998. 276(1): p. 19-42.

76. Simpson, R.T., F. Thoma, and J.M. Brubaker, Chromatin reconstituted from tandemly repeated cloned DNA fragments and core histones: a model system for study of higher order structure. Cell, 1985. 42(3): p. 799-808.

77. Ito, T., et al., Drosophila NAP-1 is a core histone chaperone that functions in ATP-facilitated assembly of regularly spaced nucleosomal arrays. Mol Cell Biol, 1996. 16(6): p. 3112-24.

78. Ito, T., et al., ACF, an ISWI-containing and ATP-utilizing chromatin assembly and remodeling factor. Cell, 1997. 90(1): p. 145-55.

79. Stillman, B., Chromatin assembly during SV4O DNA replication in vitro. Cell, 1986. 45(4): p. 555-65.

80. Sullivan, C.S. and J.M. Pipas, T antigens of simian virus 40: molecular chaperones for viral replication and tumorigenesis. Microbiol Mol Biol Rev, 2002. 66(2): p. 179-202.

81. Smith, S. and B. Stillman, Purification and characterization of CAF-I, a human cell factor required for chromatin assembly during DNA replication in vitro. Cell, 1989. 58(1): p. 15-25.

82. Kaufman, P.D., et al., The p150 and p60 subunits of chromatin assembly factor I: a molecular link between newly synthesized histones and DNA replication. Cell, 1995. 81(7): p. 1105-14.

83. Verreault, A., et al., Nucleosome assembly by a complex of CAF-1 and acetylated histones H3/H4. Cell, 1996. 87(1): p. 95-104.

84. Krude, T., Chromatin assembly factor 1 (CAF-1) colocalizes with replication foci in HeLa cell nuclei. Exp Cell Res, 1995. 220(2): p. 304-11.

85. Shibahara, K. and B. Stillman, Replication-dependent marking of DNA by PCNA facilitates CAF-1-coupled inheritance of chromatin. Cell, 1999. 96(4): p. 575-85. 
86. Laskey, R.A., A.D. Mills, and N.R. Morris, Assembly of SV40 chromatin in a cell-free system from Xenopus eggs. Cell, 1977. 10(2): p. 237-43.

87. Almouzni, G. and M. Mechali, Xenopus egg extracts: a model system for chromatin replication. Biochim Biophys Acta, 1988. 951(2-3): p. 443-50.

88. Blow, J.J. and R.A. Laskey, Initiation of DNA replication in nuclei and purified DNA by a cell-free extract of Xenopus eggs. Cell, 1986. 47(4): p. 577-87.

89. Newport, J., Nuclear reconstitution in vitro: stages of assembly around protein-free DNA. Cell, 1987. 48(2): p. 205-17.

90. Murray, A. and M. Kirschner, Cyclin synthesis drives the early embryonic cell cycle. Nature, 1989. 339(6222): p. 275-80.

91. Almouzni, G. and M. Mechali, Assembly of spaced chromatin involvement of ATP and DNA topoisomerase activity. Embo J, 1988. 7(13): p. 4355-65.

92. Almouzni, G. and M. Mechali, Assembly of spaced chromatin promoted by DNA synthesis in extracts from Xenopus eggs. Embo J, 1988. 7(3): p. 665-72.

93. Becker, P.B. and C. Wu, Cell-free system for assembly of transcriptionally repressed chromatin from Drosophila embryos. Mol Cell Biol, 1992. 12(5): p. 2241-9.

94. Mizuguchi, G., et al., ATP-dependent nucleosome remodeling and histone hyperacetylation synergistically facilitate transcription of chromatin. J Biol Chem, 2001. 276(18): p. 14773-83.

95. Becker, P.B., T. Tsukiyama, and C. Wu, Chromatin assembly extracts from Drosophila embryos. Methods Cell Biol, 1994. 44: p. 207-23.

96. Almouzni, G. and A.P. Wolffe, Nuclear assembly, structure, and function: the use of Xenopus in vitro systems. Exp Cell Res, 1993. 205(1): p. 1-15.

97. Ray-Gallet, D., et al., HIRA is critical for a nucleosome assembly pathway independent of DNA synthesis. Mol Cell, 2002. 9(5): p. 1091-100.

98. Ray-Gallet, D., et al., The histone chaperone Asf1 is dispensable for direct de novo histone deposition in Xenopus egg extracts. Chromosoma, 2007. 116(5): p. 487-96.

99. Allis, C.D., et al., Deposition-related histone acetylation in micronuclei of conjugating Tetrahymena. Proc Natl Acad Sci U S A, 1985. 82(23): p. 8048-52.

100. Ruiz-Carrillo, A., L.J. Wangh, and V.G. Allfrey, Processing of newly synthesized histone molecules. Science, 1975. 190(4210): p. 117-28.

101. Campos, E.I., et al., The program for processing newly synthesized histones H3.1 and H4. Nat Struct Mol Biol, 2010. 17(11): p. 1343-51.

102. Mello, J.A., et al., Human Asf1 and CAF-1 interact and synergize in a repair-coupled nucleosome assembly pathway. EMBO Rep, 2002. 3(4): p. 329-34.

103. Tyler, J.K., et al., Interaction between the Drosophila CAF-1 and ASF1 chromatin assembly factors. Mol Cell Biol, 2001. 21(19): p. 6574-84.

104. Sobel, R.E., et al., Conservation of deposition-related acetylation sites in newly synthesized histones H3 and H4. Proc Natl Acad Sci U S A, 1995. 92(4): p. 1237-41.

105. Jackson, V., et al., Modifications to histones immediately after synthesis. J Mol Biol, 1976. 104(2): p. 471-83.

106. Loyola, A., et al., PTMs on H3 variants before chromatin assembly potentiate their final epigenetic state. Mol Cell, 2006. 24(2): p. 309-16.

107. Groth, A., et al., Chromatin challenges during DNA replication and repair. Cell, 2007. 128(4): p. 721-33.

108. Nabatiyan, A. and T. Krude, Silencing of chromatin assembly factor 1 in human cells leads to cell death and loss of chromatin assembly during DNA synthesis. Mol Cell Biol, 2004. 24(7): p. 2853-62.

109. Houlard, M., et al., CAF-1 is essential for heterochromatin organization in pluripotent embryonic cells. PLoS Genet, 2006. 2(11): p. e181.

110. Loyola, A., et al., The HPlalpha-CAF1-SetDB1-containing complex provides H3K9me1 for Suv39-mediated K9me3 in pericentric heterochromatin. EMBO Rep, 2009. 10(7): p. 769-75.

111. Formosa, T., Changing the DNA landscape: putting a SPN on chromatin. Curr Top Microbiol Immunol, 2003. 274: p. 171-201.

112. Gambus, A., et al., GINS maintains association of Cdc45 with MCM in replisome progression complexes at eukaryotic DNA replication forks. Nat Cell Biol, 2006. 8(4): p. 358-66.

113. Tan, B.C., et al., Functional cooperation between FACT and MCM helicase facilitates initiation of chromatin DNA replication. Embo J, 2006. 25(17): p. 3975-85.

114. Chow, C.M., et al., Variant histone H3.3 marks promoters of transcriptionally active genes during mammalian cell division. EMBO Rep, 2005. 6(4): p. 354-60. 
115. McKittrick, E., et al., Histone H3.3 is enriched in covalent modifications associated with active chromatin. Proc Natl Acad Sci U S A, 2004. 101(6): p. 1525-30.

116. Drane, P., et al., The death-associated protein DAXX is a novel histone chaperone involved in the replication-independent deposition of H3.3. Genes Dev, 2010. 24(12): p. 1253-65.

117. Goldberg, A.D., et al., Distinct factors control histone variant H3.3 localization at specific genomic regions. Cell, 2010. 140(5): p. 678-91.

118. Wong, L.H., et al., ATRX interacts with H3.3 in maintaining telomere structural integrity in pluripotent embryonic stem cells. Genome Res, 2010. 20(3): p. 351-60.

119. Sawatsubashi, S., et al., A histone chaperone, DEK, transcriptionally coactivates a nuclear receptor. Genes Dev, 2010. 24(2): p. 159-70.

120. Campos, E.I. and D. Reinberg, New chaps in the histone chaperone arena. Genes Dev, 2010. 24(13): p. 1334-8.

121. Kleinschmidt, J.A., A. Seiter, and H. Zentgraf, Nucleosome assembly in vitro: separate histone transfer and synergistic interaction of native histone complexes purified from nuclei of Xenopus laevis oocytes. Embo J, 1990. 9(4): p. 1309-18.

122. Philpott, A., G.H. Leno, and R.A. Laskey, Sperm decondensation in Xenopus egg cytoplasm is mediated by nucleoplasmin. Cell, 1991. 65(4): p. 569-78.

123. Bonnefoy, E., et al., The essential role of Drosophila HIRA for de novo assembly of paternal chromatin at fertilization. PLoS Genet, 2007. 3(10): p. 1991-2006.

124. Loppin, B., et al., The histone H3.3 chaperone HIRA is essential for chromatin assembly in the male pronucleus. Nature, 2005. 437(7063): p. 1386-90.

125. van der Heijden, G.W., et al., Asymmetry in histone H3 variants and lysine methylation between paternal and maternal chromatin of the early mouse zygote. Mech Dev, 2005. 122(9): p. 1008-22.

126. Roberts, C., et al., Targeted mutagenesis of the Hira gene results in gastrulation defects and patterning abnormalities of mesoendodermal derivatives prior to early embryonic lethality. Mol Cell Biol, 2002. 22(7): p. 2318-28.

127. Krawitz, D.C., T. Kama, and P.D. Kaufman, Chromatin assembly factor I mutants defective for PCNA binding require Asf1/Hir proteins for silencing. Mol Cell Biol, 2002. 22(2): p. 61425.

128. Hake, S.B. and C.D. Allis, Histone H3 variants and their potential role in indexing mammalian genomes: the "H3 barcode hypothesis". Proc Natl Acad Sci U S A, 2006. 103(17): p. 6428-35.

129. Köster-Eiserfunke, N., Characterization of Lin-61 methyl mark binding and its function in $C$. elegans vulva development, in Laboratory of Chromatin Biochemisrty2010, Max Planck Institute for Biophysical Chemistry: Göttingen.

130. An, W. and R.G. Roeder, Reconstitution and transcriptional analysis of chromatin in vitro. Methods Enzymol, 2004. 377: p. 460-74.

131. Robinson, P.J., et al., EM measurements define the dimensions of the "30-nm" chromatin fiber: evidence for a compact, interdigitated structure. Proc Natl Acad Sci U S A, 2006. 103(17): p. 6506-11.

132. Sambrook, J., D.W. Russell, and C.S.H. Laboratory, Molecular cloning : a laboratory manual / Joseph Sambrook, David W. Russell 3rd ed. ed, ed. C.S.H. Laboratory2001, Cold Spring Harbor, N.Y.

133. Guilliatt, A.M., Agarose and polyacrylamide gel electrophoresis. Methods Mol Biol, 2002. 187: p. 1-11.

134. Luger, K., T.J. Rechsteiner, and T.J. Richmond, Expression and purification of recombinant histones and nucleosome reconstitution. Methods Mol Biol, 1999. 119: p. 1-16.

135. Luger, K., T.J. Rechsteiner, and T.J. Richmond, Preparation of nucleosome core particle from recombinant histones. Methods Enzymol, 1999. 304: p. 3-19.

136. Hanahan, D., Studies on transformation of Escherichia coli with plasmids. J Mol Biol, 1983. 166(4): p. 557-80.

137. Sawadogo, M. and R.G. Roeder, Factors involved in specific transcription by human RNA polymerase II: analysis by a rapid and quantitative in vitro assay. Proc Natl Acad Sci U S A, 1985. 82(13): p. 4394-8.

138. Vieira, J. and J. Messing, Production of single-stranded plasmid DNA. Methods Enzymol, 1987. 153: p. 3-11.

139. Lin, J.J., et al., DH11S: an Escherichia coli strain for preparation of single-stranded DNA from phagemid vectors. Biotechniques, 1992. 12(5): p. 718-21. 
140. Gasteiger, E., et al., ExPASy: The proteomics server for in-depth protein knowledge and analysis. Nucleic Acids Res, 2003. 31(13): p. 3784-8.

141. Laemmli, U.K., Cleavage of structural proteins during the assembly of the head of bacteriophage T4. Nature, 1970. 227(5259): p. 680-5.

142. Gallagher, S.R., One-dimensional SDS gel electrophoresis of proteins. Curr Protoc Cell Biol, 2007. Chapter 6: p. Unit 61.

143. Kaufmann, S.H., C.M. Ewing, and J.H. Shaper, The erasable Western blot. Anal Biochem, 1987. 161(1): p. 89-95.

144. Shogren-Knaak, M.A. and C.L. Peterson, Creating designer histones by native chemical ligation. Methods Enzymol, 2004. 375: p. 62-76.

145. Walter, J., L. Sun, and J. Newport, Regulated chromosomal DNA replication in the absence of a nucleus. Mol Cell, 1998. 1(4): p. 519-29.

146. Tutter, A.V. and J.C. Walter, Chromosomal DNA replication in a soluble cell-free system derived from Xenopus eggs. Methods Mol Biol, 2006. 322: p. 121-37.

147. Gurdon, J.B., Injected nuclei in frog oocytes: fate, enlargement, and chromatin dispersal. J Embryol Exp Morphol, 1976. 36(3): p. 523-40.

148. Gaillard, P.H., D. Roche, and G. Almouzni, Nucleotide excision repair coupled to chromatin assembly. Methods Mol Biol, 1999. 119: p. 231-43.

149. Bonasera, V., S. Alberti, and A. Sacchetti, Protocol for high-sensitivity/long linear-range spectrofluorimetric DNA quantification using ethidium bromide. Biotechniques, 2007. 43(2): p. 173-4, 176.

150. Dignam, J.D., R.M. Lebovitz, and R.G. Roeder, Accurate transcription initiation by RNA polymerase II in a soluble extract from isolated mammalian nuclei. Nucleic Acids Res, 1983. 11(5): p. 1475-89.

151. Dignam, J.D., et al., Eukaryotic gene transcription with purified components. Methods Enzymol, 1983. 101: p. 582-98.

152. Shevchenko, A., et al., Mass spectrometric sequencing of proteins silver-stained polyacrylamide gels. Anal Chem, 1996. 68(5): p. 850-8.

153. Scharf, A.N., et al., Monomethylation of lysine 20 on histone $H 4$ facilitates chromatin maturation. Mol Cell Biol, 2009. 29(1): p. 57-67.

154. Leuba, S.H. and C. Bustamante, Analysis of chromatin by scanning force microscopy. Methods Mol Biol, 1999. 119: p. 143-60.

155. Sörös, S., H3K9me3 dependent HP1 chromatin association and its consequences for chromatin packaging, in Laboratory of Chromatin Biochemisrty2010, Max Planck Institute for Biophysical Chemistry: Göttingen.

156. Li, J.J. and T.J. Kelly, Simian virus 40 DNA replication in vitro. Proc Natl Acad Sci U S A, 1984. 81(22): p. 6973-7.

157. Almouzni, G., et al., Chromatin assembly on replicating DNA in vitro. Nucleic Acids Res, 1990. 18(19): p. 5767-74.

158. Almouzni, G., M. Mechali, and A.P. Wolffe, Competition between transcription complex assembly and chromatin assembly on replicating DNA. Embo J, 1990. 9(2): p. 573-82.

159. Almouzni, G., M. Mechali, and A.P. Wolffe, Transcription complex disruption caused by a transition in chromatin structure. Mol Cell Biol, 1991. 11(2): p. 655-65.

160. Wolffe, A.P., Chromatin: Structure and Function. 3rd ed1998, San Diego, CA: Academic Press.

161. Yokoyama, E., et al., Detection of the single-stranded DNA of Streptomyces plasmid pSA1.1 and a binding histone-like protein. FEMS Microbiol Lett, 1996. 138(2-3): p. 197-200.

162. Clark, D.J. and T. Kimura, Electrostatic mechanism of chromatin folding. J Mol Biol, 1990. 211(4): p. 883-96.

163. Hansen, J.C., et al., Homogeneous reconstituted oligonucleosomes, evidence for saltdependent folding in the absence of histone H1. Biochemistry, 1989. 28(23): p. 9129-36.

164. Schwarz, P.M., et al., Reversible oligonucleosome self-association: dependence on divalent cations and core histone tail domains. Biochemistry, 1996. 35(13): p. 4009-15.

165. Cho, H. and A.P. Wolffe, Xenopus laevis B4, an intron-containing oocyte-specific linker histone-encoding gene. Gene, 1994. 143(2): p. 233-8.

166. Dimitrov, S., et al., Chromatin transitions during early Xenopus embryogenesis: changes in histone H4 acetylation and in linker histone type. Dev Biol, 1993. 160(1): p. 214-27.

167. Smith, R.C., E. Dworkin-Rastl, and M.B. Dworkin, Expression of a histone H1-like protein is restricted to early Xenopus development. Genes Dev, 1988. 2(10): p. 1284-95. 
168. Lurquin, P.F. and V.L. Seligy, Binding of ethidium bromide to avian erythrocyte chromatin. Biochem Biophys Res Commun, 1972. 46(3): p. 1399-404.

169. Dimitrov, S., M.C. Dasso, and A.P. Wolffe, Remodeling sperm chromatin in Xenopus laevis egg extracts: the role of core histone phosphorylation and linker histone B4 in chromatin assembly. J Cell Biol, 1994. 126(3): p. 591-601.

170. Loyola, A. and G. Almouzni, Histone chaperones, a supporting role in the limelight. Biochim Biophys Acta, 2004. 1677(1-3): p. 3-11.

171. Gaillard, P.H., et al., Chromatin assembly coupled to DNA repair: a new role for chromatin assembly factor I. Cell, 1996. 86(6): p. 887-96.

172. Belotserkovskaya, R. and D. Reinberg, Facts about FACT and transcript elongation through chromatin. Curr Opin Genet Dev, 2004. 14(2): p. 139-46.

173. Orphanides, G., et al., FACT, a factor that facilitates transcript elongation through nucleosomes. Cell, 1998. 92(1): p. 105-16.

174. Orphanides, G., et al., The chromatin-specific transcription elongation factor FACT comprises human SPT16 and SSRP1 proteins. Nature, 1999. 400(6741): p. 284-8.

175. Okuhara, K., et al., A DNA unwinding factor involved in DNA replication in cell-free extracts of Xenopus eggs. Curr Biol, 1999. 9(7): p. 341-50.

176. Philpott, A. and G.H. Leno, Nucleoplasmin remodels sperm chromatin in Xenopus egg extracts. Cell, 1992. 69(5): p. 759-67.

177. Conaway, R.C. and J.W. Conaway, The INO80 chromatin remodeling complex in transcription, replication and repair. Trends Biochem Sci, 2009. 34(2): p. 71-7.

178. Wade, P.A., et al., A multiple subunit Mi-2 histone deacetylase from Xenopus laevis cofractionates with an associated Snf2 superfamily ATPase. Curr Biol, 1998. 8(14): p. 843-6.

179. Minc, E., J.C. Courvalin, and B. Buendia, HPlgamma associates with euchromatin and heterochromatin in mammalian nuclei and chromosomes. Cytogenet Cell Genet, 2000. 90(34): p. 279-84.

180. Xu, M., et al., Partitioning of histone H3-H4 tetramers during DNA replication-dependent chromatin assembly. Science, 2010. 328(5974): p. 94-8.

181. Santisteban, M.S., T. Kalashnikova, and M.M. Smith, Histone H2A.Z regulats transcription and is partially redundant with nucleosome remodeling complexes. Cell, 2000. 103(3): p. 41122.

182. Jin, C. and G. Felsenfeld, Nucleosome stability mediated by histone variants H3.3 and H2A.Z. Genes Dev, 2007. 21(12): p. 1519-29.

183. Suto, R.K., et al., Crystal structure of a nucleosome core particle containing the variant histone H2A.Z. Nat Struct Biol, 2000. 7(12): p. 1121-4.

184. Krogan, N.J., et al., A Snf2 family ATPase complex required for recruitment of the histone $H 2 A$ variant $H t z 1$. Mol Cell, 2003. 12(6): p. 1565-76.

185. Mizuguchi, G., et al., ATP-driven exchange of histone H2AZ variant catalyzed by SWR1 chromatin remodeling complex. Science, 2004. 303(5656): p. 343-8.

186. Kobor, M.S., et al., A protein complex containing the conserved Swi2/Snf2-related ATPase Swrlp deposits histone variant H2A.Z into euchromatin. PLoS Biol, 2004. 2(5): p. E131.

187. Heo, K., et al., FACT-mediated exchange of histone variant $H 2 A X$ regulated by phosphorylation of H2AX and ADP-ribosylation of Spt16. Mol Cell, 2008. 30(1): p. 86-97.

188. Houston, S.I., et al., Catalytic function of the PR-Set7 histone H4 lysine 20 monomethyltransferase is essential for mitotic entry and genomic stability. J Biol Chem, 2008. 283(28): p. 19478-88.

189. Sims, J.K. and J.C. Rice, PR-Set7 establishes a repressive trans-tail histone code that regulates differentiation. Mol Cell Biol, 2008. 28(14): p. 4459-68.

190. Talasz, H., et al., Histone H4-lysine 20 monomethylation is increased in promoter and coding regions of active genes and correlates with hyperacetylation. J Biol Chem, 2005. 280(46): p. 38814-22.

191. Schubeler, D., et al., The histone modification pattern of active genes revealed through genome-wide chromatin analysis of a higher eukaryote. Genes Dev, 2004. 18(11): p. 1263-71.

192. Guenther, M.G., et al., A chromatin landmark and transcription initiation at most promoters in human cells. Cell, 2007. 130(1): p. 77-88.

193. Bernstein, B.E., et al., A bivalent chromatin structure marks key developmental genes in embryonic stem cells. Cell, 2006. 125(2): p. 315-26.

194. Shechter, D., et al., Analysis of histones in Xenopus laevis. I. A distinct index of enriched variants and modifications exists in each cell type and is remodeled during developmental transitions. J Biol Chem, 2009. 284(2): p. 1064-74. 
195. Dillon, S.C., et al., The SET-domain protein superfamily: protein lysine methyltransferases. Genome Biol, 2005. 6(8): p. 227.

196. Briggs, S.D., et al., Gene silencing: trans-histone regulatory pathway in chromatin. Nature, 2002. 418(6897): p. 498.

197. Ng, H.H., et al., Ubiquitination of histone H2B by Rad6 is required for efficient Dot1mediated methylation of histone H3 lysine 79. J Biol Chem, 2002. 277(38): p. 34655-7.

198. Jacobs, S.A., W. Fischle, and S. Khorasanizadeh, Assays for the determination of structure and dynamics of the interaction of the chromodomain with histone peptides. Methods Enzymol, 2004. 376: p. 131-48.

199. Nakayama, T., et al., Drosophila GAGA factor directs histone H3.3 replacement that prevents the heterochromatin spreading. Genes Dev, 2007. 21(5): p. 552-61.

200. Banumathy, G., et al., Human UBN1 is an ortholog of yeast Hpc2p and has an essential role in the HIRA/ASFla chromatin-remodeling pathway in senescent cells. Mol Cell Biol, 2009. 29(3): p. 758-70.

201. Lorain, S., et al., Core histones and HIRIP3, a novel histone-binding protein, directly interact with WD repeat protein HIRA. Mol Cell Biol, 1998. 18(9): p. 5546-56.

202. Ruthenburg, A.J., C.D. Allis, and J. Wysocka, Methylation of lysine 4 on histone H3: intricacy of writing and reading a single epigenetic mark. Mol Cell, 2007. 25(1): p. 15-30.

203. Sadowski, I., et al., GAL4-VP16 is an unusually potent transcriptional activator. Nature, 1988. 335(6190): p. 563-4.

204. Prioleau, M.N., et al., Competition between chromatin and transcription complex assembly regulates gene expression during early development. Cell, 1994. 77(3): p. 439-49.

205. Newport, J. and M. Kirschner, A major developmental transition in early Xenopus embryos: II. Control of the onset of transcription. Cell, 1982. 30(3): p. 687-96.

206. Almouzni, G. and A.P. Wolffe, Constraints on transcriptional activator function contribute to transcriptional quiescence during early Xenopus embryogenesis. Embo J, 1995. 14(8): p. 1752-65.

207. Prioleau, M.N., R.S. Buckle, and M. Mechali, Programming of a repressed but committed chromatin structure during early development. Embo J, 1995. 14(20): p. 5073-84.

208. Li, G., et al., Highly compacted chromatin formed in vitro reflects the dynamics of transcription activation in vivo. Mol Cell, 2010. 38(1): p. 41-53.

209. Robinson, P.J., et al., $30 \mathrm{~nm}$ chromatin fibre decompaction requires both H4-K16 acetylation and linker histone eviction. J Mol Biol, 2008. 381(4): p. 816-25.

210. Tse, C., et al., Disruption of higher-order folding by core histone acetylation dramatically enhances transcription of nucleosomal arrays by RNA polymerase III. Mol Cell Biol, 1998. 18(8): p. 4629-38.

211. Neely, K.E. and J.L. Workman, The complexity of chromatin remodeling and its links to cancer. Biochim Biophys Acta, 2002. 1603(1): p. 19-29.

212. Santos-Rosa, H., et al., Methylation of histone H3 K4 mediates association of the Iswlp ATPase with chromatin. Mol Cell, 2003. 12(5): p. 1325-32.

213. Kalakonda, N., et al., Histone H4 lysine 20 monomethylation promotes transcriptional repression by L3MBTL1. Oncogene, 2008. 27(31): p. 4293-304.

214. Li, H., et al., Structural basis for lower lysine methylation state-specific readout by $M B T$ repeats of L3MBTL1 and an engineered PHD finger. Mol Cell, 2007. 28(4): p. 677-91.

215. Trojer, P., et al., L3MBTL1, a histone-methylation-dependent chromatin lock. Cell, 2007. 129(5): p. 915-28.

216. Sakaguchi, A. and R. Steward, Aberrant monomethylation of histone H4 lysine 20 activates the DNA damage checkpoint in Drosophila melanogaster. J Cell Biol, 2007. 176(2): p. 15562.

217. Oda, H., et al., Monomethylation of histone H4-lysine 20 is involved in chromosome structure and stability and is essential for mouse development. Mol Cell Biol, 2009. 29(8): p. 2278-95.

218. Huen, M.S., et al., Direct interaction between SET8 and proliferating cell nuclear antigen couples H4-K20 methylation with DNA replication. J Biol Chem, 2008. 283(17): p. 11073-7.

219. Centore, R.C., et al., CRL4(Cdt2)-mediated destruction of the histone methyltransferase Set8 prevents premature chromatin compaction in S phase. Mol Cell, 2010. 40(1): p. 22-33.

220. Tardat, M., et al., The histone H4 Lys 20 methyltransferase PR-Set7 regulates replication origins in mammalian cells. Nat Cell Biol, 2010. 12(11): p. 1086-93.

221. Jorgensen, S., et al., The histone methyltransferase SET8 is required for S-phase progression. J Cell Biol, 2007. 179(7): p. 1337-45. 
222. Tardat, M., et al., PR-Set7-dependent lysine methylation ensures genome replication and stability through S phase. J Cell Biol, 2007. 179(7): p. 1413-26.

223. Abbas, T., et al., CRL4(Cdt2) regulates cell proliferation and histone gene expression by targeting PR-Set7/Set8 for degradation. Mol Cell, 2010. 40(1): p. 9-21.

224. Jorgensen, S., et al., SET8 is degraded via PCNA-coupled CRL4(CDT2) ubiquitylation in S phase and after UV irradiation. J Cell Biol, 2011. 192(1): p. 43-54.

225. Oda, H., et al., Regulation of the histone H4 monomethylase PR-Set7 by CRL4(Cdt2)mediated PCNA-dependent degradation during DNA damage. Mol Cell, 2010. 40(3): p. 36476.

226. Leibovici, M., et al., Characterization and developmental expression of Xenopus proliferating cell nuclear antigen (PCNA). Dev Biol, 1990. 141(1): p. 183-92.

227. Ooi, S.L., J.R. Priess, and S. Henikoff, Histone H3.3 variant dynamics in the germline of Caenorhabditis elegans. PLoS Genet, 2006. 2(6): p. e97.

228. Vermeulen, M., et al., Selective anchoring of TFIID to nucleosomes by trimethylation of histone H3 lysine 4. Cell, 2007. 131(1): p. 58-69.

229. Sims, J.K., et al., A trans-tail histone code defined by monomethylated H4 Lys-20 and H3 Lys9 demarcates distinct regions of silent chromatin. J Biol Chem, 2006. 281(18): p. 12760-6.

230. Vakoc, C.R., et al., Profile of histone lysine methylation across transcribed mammalian chromatin. Mol Cell Biol, 2006. 26(24): p. 9185-95.

231. Barski, A., et al., High-resolution profiling of histone methylations in the human genome. Cell, 2007. 129(4): p. 823-37.

232. Li, Y., et al., The Histone Modifications Governing TFF1 Transcription Mediated by Estrogen Receptor. J Biol Chem, 2011. 286(16): p. 13925-36.

233. Li, Z., et al., Histone H4 Lys 20 monomethylation by histone methylase SET8 mediates Wnt target gene activation. Proc Natl Acad Sci U S A, 2011. 108(8): p. 3116-23.

234. Tang, Y., et al., Structure of a human ASF1a-HIRA complex and insights into specificity of histone chaperone complex assembly. Nat Struct Mol Biol, 2006. 13(10): p. 921-9.

235. English, C.M., et al., Structural basis for the histone chaperone activity of Asf1. Cell, 2006. 127(3): p. 495-508.

236. Mousson, F., et al., Structural basis for the interaction of Asfl with histone H3 and its functional implications. Proc Natl Acad Sci U S A, 2005. 102(17): p. 5975-80.

237. Dilworth, S.M., S.J. Black, and R.A. Laskey, Two complexes that contain histones are required for nucleosome assembly in vitro: role of nucleoplasmin and N1 in Xenopus egg extracts. Cell, 1987. 51(6): p. 1009-18.

238. Shechter, D., et al., A distinct H2A.X isoform is enriched in Xenopus laevis eggs and early embryos and is phosphorylated in the absence of a checkpoint. Proc Natl Acad Sci U S A, 2009. 106(3): p. 749-54.

239. Redon, C., et al., Histone $H 2 A$ variants $H 2 A X$ and $H 2 A Z$. Curr Opin Genet Dev, 2002. 12(2): p. 162-9.

240. Stuwe, T., et al., The FACT Spt16 "peptidase" domain is a histone H3-H4 binding module. Proc Natl Acad Sci U S A, 2008. 105(26): p. 8884-9.

241. Wright, S.J., Sperm nuclear activation during fertilization. Curr Top Dev Biol, 1999. 46: p. 133-78.

242. Aoki, F., D.M. Worrad, and R.M. Schultz, Regulation of transcriptional activity during the first and second cell cycles in the preimplantation mouse embryo. Dev Biol, 1997. 181(2): p. 296-307.

243. Wolffe, A.P., Transcriptional activation of Xenopus class III genes in chromatin isolated from sperm and somatic nuclei. Nucleic Acids Res, 1989. 17(2): p. 767-80.

244. Li, E., T.H. Bestor, and R. Jaenisch, Targeted mutation of the DNA methyltransferase gene results in embryonic lethality. Cell, 1992. 69(6): p. 915-26.

245. Quivy, J.P., et al., The HP1-p150/CAF-1 interaction is required for pericentric heterochromatin replication and S-phase progression in mouse cells. Nat Struct Mol Biol, 2008. 15(9): p. 972-9.

246. Quivy, J.P., et al., A CAF-1 dependent pool of HP1 during heterochromatin duplication. Embo J, 2004. 23(17): p. 3516-26.

247. Huang, H., et al., Drosophila CAF-1 regulates HP1-mediated epigenetic silencing and pericentric heterochromatin stability. J Cell Sci, 2010. 123(Pt 16): p. 2853-61. 


\section{$7 \quad$ Appendix}

Table 7.1 | Mascot result of dsDNA sample after substraction of proteins of mock and ssDNA samples.

\begin{tabular}{|c|c|c|c|}
\hline GI Number & Protein Description (Mascot) & Score & Name (Blast) \\
\hline gi|50603788 & Unknown (protein for MGC:82390) & 1855 & heat shock $70 \mathrm{kDa}$ protein \\
\hline gi|2370591 & translation initiation factor eIF4A I & 1025 & translation initiation factor eIF4A I \\
\hline gi| 148232250 & XMCM7 & 710 & DNA replication licensing factor mcm $7-A$ \\
\hline gi|4504279 & $\mathrm{H} 3$ histone, family $3 \mathrm{~A}$ & 647 & H3.3 \\
\hline gi|4630797 & human $\mathrm{Ku} 70$ autoantigen homologue & 619 & $\mathrm{Ku} 70$ autoantigen \\
\hline gi|147901554 & $\mathrm{Na}+/ \mathrm{K}+$-ATPase alpha 3 subunit & 514 & $\mathrm{Na}+/ \mathrm{K}+$-ATPase alpha 3 subunit \\
\hline gi|4630799 & human Ku80 autoantigen homologue & 512 & Ku80 autoantigen \\
\hline gi|147904940 & hypothetical protein LOC100037169 & 486 & $\begin{array}{l}\text { similar to vertebrate PRP4 (pre-mRNA processing } \\
\text { factor } 4 \text { homologue B) }\end{array}$ \\
\hline gi|148233082 & $\begin{array}{l}\text { WD repeat and HMG-box DNA binding } \\
\text { protein } 1\end{array}$ & 364 & $\begin{array}{l}\text { Anti -WD Repeat and HMG Box DNA Binding } \\
\text { Protein } 1 \text { (WDHD1, Acidic Nucleoplasmic DNA } \\
\text { Binding Protein 1, And-1) }\end{array}$ \\
\hline gi| 148232688 & nucleolar phosphoprotein & 361 & nucleolar phosphoprotein \\
\hline gi|49114894 & LOC397940 protein & 296 & coilin \\
\hline gi|27881711 & MGC52578 protein & 291 & HMG-2 \\
\hline gi| 148230122 & hypothetical protein LOC734971 & 278 & cyclin L1 \\
\hline gi|147900472 & MGC81970 protein & 268 & RNA binding motif protein 39 \\
\hline gi|48734622 & Unknown (protein for MGC:78911) & 249 & Importin alpha-7 subunit \\
\hline gi|6172233 & Xsal-3 long form & 232 & $\begin{array}{l}\text { Sal-3 (zinc finger transcription factor/importin-beta } \\
\text { homologue) }\end{array}$ \\
\hline gi|148224686 & chromobox homologue 3 a & 225 & HP1 gamma \\
\hline gi|49119281 & XNopp180 protein & 205 & $\begin{array}{l}\text { XNopp180 (nucleolar and coiled-body } \\
\text { phosphoprotein) }\end{array}$ \\
\hline gi|86577716 & Unknown (protein for MGC:132292) & 197 & DEK oncogene \\
\hline gi|147901426 & hypothetical protein LOC432217 & 194 & $\begin{array}{l}\text { zinc finger and BTB domain containing } 2 \text { - } \\
\text { transcription factor }\end{array}$ \\
\hline gi|27370919 & LOC398543 protein & 184 & similar to DEK oncogene \\
\hline gi|16974922 & $\begin{array}{l}\text { Chain A, The Crystal Structure Of } \\
\text { Nucleoplasmin-Core }\end{array}$ & 180 & Nucleoplasmin \\
\hline gi|147906312 & hypothetical protein LOC734592 & 172 & DNA topoisomerase I \\
\hline gi| 15809658 & survival motor neuron & 170 & $\begin{array}{l}\text { survival motor neuron (SMN-involved in the } \\
\text { assembly of snRNPs, the essential components of } \\
\text { spliceosomal machinery) }\end{array}$ \\
\hline gi|833629 & nucleoplasmin & 151 & Nucleoplasmin \\
\hline gi| 148225646 & MGC80961 protein & 150 & cortactin (F-actin-associated protein) \\
\hline gi|147906611 & hypothetical protein LOC734527 & 146 & PR-SET7-like protein \\
\hline gi|148232874 & hypothetical protein LOC398881 & 145 & $\begin{array}{l}\text { LUC7-like } 3 \text { (LUC7 - U1 snRNA associated protein } \\
\text { with a role in splice site recognition) }\end{array}$ \\
\hline gi|148230663 & hydrogen/potassium-exchanging ATPase $12 \mathrm{~A} \mathrm{~b}$ & 138 & hydrogen/potassium-exchanging ATPase $12 \mathrm{~A} \mathrm{~b}$ \\
\hline gi|27882053 & Gdi2-prov protein & 133 & $\begin{array}{l}\text { Gdi2-prov protein (Rab GDP dissociation inhibitor } \\
\text { beta) }\end{array}$ \\
\hline gi| 148230114 & Mi-2 histone deacetylase complex protein 66 & 125 & Mi-2/NURD deacetylase complex \\
\hline gi|6093627 & $\begin{array}{l}\text { RecName: Full=Origin recognition complex } \\
\text { subunit } 4\end{array}$ & 117 & ORC4 \\
\hline gi| 147900863 & MGC80921 protein precursor & 105 & $\begin{array}{l}\text { dolichyl-diphosphooligosaccharide--protein } \\
\text { glycosyltransferase }\end{array}$ \\
\hline gi| 148238177 & MGC81274 protein & 101 & $\begin{array}{l}\text { syndecan binding protein (component of cell adhesion } \\
\text { sites and microfilaments) }\end{array}$ \\
\hline gi|147905356 & MGC80667 protein & 95 & $\begin{array}{l}\text { SWI/SNF related, matrix associated, actin dependent } \\
\text { regulator of chromatin, subfamily a, member } 1\end{array}$ \\
\hline gi|147900217 & $\begin{array}{l}\text { guanine nucleotide binding protein ( } \mathrm{G} \text { protein), } \\
\text { alpha activating activity polypeptide } \mathrm{O}\end{array}$ & 94 & guanine nucleotide binding protein (G protein) \\
\hline gi|9988777 & protein kinase AIRK2 & 91 & protein kinase AIRK2 \\
\hline gi|148232870 & $\begin{array}{l}\text { similar to protein kinase } \mathrm{C} \text { and casein kinase } \\
\text { substrate in neurons } 3\end{array}$ & 90 & protein kinase $\mathrm{C}$ \\
\hline gi| 13432110 & $\begin{array}{l}\text { "RecName: Full=Blastomere cadherin; } \\
\text { Short=B-cadherin }\end{array}$ & 89 & cadherin \\
\hline
\end{tabular}




\begin{tabular}{|c|c|c|c|}
\hline gi|40286642 & nucleoporin Nup88B & 88 & nucleoporin Nup88B \\
\hline gi|125705 & $\begin{array}{l}\text { "RecName: Full=Tyrosine-protein kinase Src- } \\
\text { 2; AltName: Full=p60-Src-2" }\end{array}$ & 79 & Tyrosine-protein kinase Src-2 \\
\hline gi|147904154 & hypothetical protein LOC734763 & 74 & WD repeat domain 34 \\
\hline gi|124961 & $\begin{array}{l}\text { "RecName: Full=Integrin beta-1-B; AltName: } \\
\text { Full=Integrin beta-1*; Flags: Precursor" }\end{array}$ & 72 & Integrin beta-1B \\
\hline gi|124481722 & Unknown (protein for IMAGE:5440084) & 71 & alpha-2-macroglobulin-like 1 \\
\hline gi|147899531 & MGC82578 protein & 70 & Surfeit 4 (integral membrane protein) \\
\hline gi|148227279 & hypothetical protein LOC734752 & 68 & receptor accessory protein 5 \\
\hline gi|148225100 & $\begin{array}{l}\text { SWI/SNF related, matrix associated, actin } \\
\text { dependent regulator of chromatin, subfamily c, } \\
\text { member } 1\end{array}$ & 67 & SWI/SNF \\
\hline gi|148238205 & hypothetical protein LOC734624 & 63 & developmental pluripotency-associated protein (Dppa) \\
\hline gi|147899553 & MGC80567 protein & 62 & $\begin{array}{l}\text { similar to KIAA0174 (IST1 homologue, putative } \\
\text { MAPK-activating protein PM28) }\end{array}$ \\
\hline gi|147907326 & ATPase, $\mathrm{Ca}++$ transporting, slow twitch 2 & 57 & ATPase, $\mathrm{Ca}^{2+}$ transporting, slow twitch 2 \\
\hline gi|66912011 & XL-INCENP protein & 54 & INCENP \\
\hline gi|16303786 & SP22 & 54 & SP22 (mitochondrial protein) \\
\hline gi|148235903 & hypothetical protein LOC734291 & 54 & dnaJ homologue subfamily B member 6-A \\
\hline gi|148235590 & hypothetical protein LOC735162 & 54 & syntaxin binding protein 3 \\
\hline gi|148236079 & similar to dynamin 1-like & 54 & dynamin 1-like \\
\hline gi|148232746 & MGC80838 protein & 53 & prostaglandin reductase 1 \\
\hline gi|148229128 & MGC83916 protein & 52 & $\begin{array}{l}\text { MTA1 - metastasis associated } 1 \text { (protein complex } \\
\text { with HDAC } 1 / 2 \rightarrow \text { NuRD complex) }\end{array}$ \\
\hline gi|27882172 & LOC779015 protein & 51 & transmembrane emp24-like trafficking protein 10 \\
\hline gi|148230911 & transcription factor RAM2 & 51 & transcription factor RAM2 \\
\hline gi|148227396 & pentraxin fusion protein & 51 & pentraxin \\
\hline gi|148223583 & hypothetical protein LOC734658 & 50 & t-SNARE domain containing 1 \\
\hline gi|147900710 & centromere protein E (kinesin-related protein) & 49 & $\begin{array}{l}\text { centromere protein E (kinesin-related protein, } \\
\text { CENPE) }\end{array}$ \\
\hline gi|148236261 & beta-transducin repeat containing protein & 46 & $\begin{array}{l}\text { beta-transducin repeat containing protein (F-box/WD } \\
\text { repeat-containing protein, pIkappaBalpha-E3 receptor } \\
\text { subunit ) }\end{array}$ \\
\hline gi|50415131 & LOC445856 protein & 45 & PREDICTED: vacuolar protein sorting 13 \\
\hline gi|147899246 & MGC84721 protein & 44 & coiled-coil domain containing 19 \\
\hline gi|148222862 & myosin, heavy polypeptide 15 & 44 & myosin \\
\hline gi|63108302 & xSurvivin1A & 42 & Survivin (inhibitor of apoptosis protein) \\
\hline gi|147900245 & hypothetical protein LOC735212 & 42 & ras-related protein Rab-19 \\
\hline gi|148222373 & hypothetical protein LOC414616 & 41 & protein phosphatase 1 regulatory subunit $3 \mathrm{C}$ \\
\hline gi|11907548 & calcineurin catalytic subunit & 41 & calcineurin \\
\hline gi|148234431 & hypothetical protein LOC403361 & 41 & isoleucyl-tRNA synthetase \\
\hline gi|148233786 & MGC80246 protein & 40 & $\begin{array}{l}\text { capping protein (actin filament) muscle Z-line, alpha } \\
2\end{array}$ \\
\hline gi|213623648 & Cas/HEF-like protein 1 & 40 & Cas/HEF-like protein 1 (scaffolding protein) \\
\hline gi|28838479 & Actr8-prov protein & 39 & Arp8 (Actr8, subunit of INO80 complex) \\
\hline gi|148225306 & activating transcription factor 1 & 39 & ATF-1 (activating transcription factor 1 ) \\
\hline gi|147904501 & hypothetical protein LOC432288 & 39 & peroxisomal membrane protein PEX16 \\
\hline gi|62858321 & $\begin{array}{l}\text { splicing factor } 3 \mathrm{~b} \text {, subunit } 5,10 \mathrm{kDa} \text { [Xenopus } \\
\text { (Silurana) tropicalis] }\end{array}$ & 39 & splicing factor $3 \mathrm{~b}$ \\
\hline gi|148234178 & hypothetical protein LOC779274 & 37 & cytoplasmic tRNA 2-thiolation protein 1 \\
\hline gi|6016103 & $\begin{array}{l}\text { "RecName: Full=Guanine nucleotide-binding } \\
\text { protein subunit alpha-14; Short=G-protein } \\
\text { subunit alpha-14; Short=G alpha-14" }\end{array}$ & 37 & Guanine nucleotide-binding protein subunit alpha-14 \\
\hline gi|27769132 & MGC52843 protein & 36 & $\begin{array}{l}\text { TATA box binding protein (TBP)-associated factor, } \\
\text { RNA polymerase I, B (TAF1B) }\end{array}$ \\
\hline gi|147900125 & dickkopf homologue 1 & 35 & dickkopf 1 (negative regulator of Wnt signaling) \\
\hline gi|147904545 & transcription elongation factor XSII-K1 & 35 & transcription elongation factor XSII-K1 \\
\hline gi|148227451 & $\begin{array}{l}\text { propionyl-Coenzyme A carboxylase, alpha } \\
\text { polypeptide }\end{array}$ & 34 & propionyl-Coenzyme A carboxylase \\
\hline gi|28302315 & LOC398496 protein & 33 & junction plakoglobin \\
\hline gi|148224032 & hypothetical protein LOC432239 & 33 & nucleoporin NUP53 \\
\hline gi|49257246 & LOC443570 protein & 32 & $\begin{array}{l}\text { PREDICTED: interferon-induced protein with } \\
\text { tetratricopeptide repeats 5-like }\end{array}$ \\
\hline gi|47123899 & VLDLR protein & 32 & $\begin{array}{l}\text { VLDLR protein (very low density lipoprotein } \\
\text { receptor) }\end{array}$ \\
\hline gi|147901942 & axin & 32 & axin \\
\hline
\end{tabular}




\begin{tabular}{|c|c|c|c|}
\hline gi|76779566 & LOC733349 protein & 31 & $\begin{array}{l}\text { PREDICTED: AT-rich interactive domain-containing } \\
\text { protein 3B-like }\end{array}$ \\
\hline gi|66912037 & LOC733251 protein & 31 & arginyl-tRNA synthetase, cytoplasmic \\
\hline
\end{tabular}

Table 7.2 | Mascot result of ssDNA sample after substraction of proteins present in mock and dsDNA.

\begin{tabular}{|c|c|c|c|}
\hline GI Number & Protein Description (Mascot) & Score & Name (Blast) \\
\hline gi|148228066 & ATP-dependent DNA helicase 2 subunit 1 & 3014 & ATP-dependent DNA helicase 2 subunit 1 \\
\hline gi|148230178 & elongation factor 1-alpha $\mathrm{O}$ & 832 & elongation factor 1 -alpha $\mathrm{O}$ \\
\hline gi|147899952 & purine-rich element binding protein $\mathrm{B}$ & 311 & purine-rich element binding protein $\mathrm{B}$ \\
\hline gi|147905959 & glutathione S-transferase mu 2 & 298 & $\begin{array}{l}\text { Gstm2 (glutathione S-transferase mu 2) subunit of } \\
\text { glutathione S-transferase }\end{array}$ \\
\hline gi|136657 & $\begin{array}{l}\text { "RecName: Full=Nucleolar transcription factor } \\
\text { 1-B; AltName: Full=Upstream-binding factor } \\
\text { 1-B }\end{array}$ & 153 & Upstream-binding factor 1-B (UBF-1-B) \\
\hline gi|3599503 & $\begin{array}{l}\text { guanine nucleotide-binding protein Gi alpha } \\
\text { subunit }\end{array}$ & 141 & guanine nucleotide-binding protein Gi alpha subunit \\
\hline gi|62857747 & hypothetical protein LOC549517 & 250 & N-RAS \\
\hline gi|49116980 & Ccnl1 protein & 239 & Ccnl1 (Cyclin-L1) \\
\hline gi|148222808 & Ralb protein precursor & 196 & Ralb protein precursor (Ras-like small GTPases) \\
\hline gi|147900510 & MGC82579 protein & 167 & heat shock protein $90 \mathrm{kDa}$ alpha \\
\hline gi|148234674 & hypothetical protein LOC398898 & 50 & clathrin, light chain B \\
\hline gi|148229058 & elogation factor 1 beta & 131 & elogation factor 1 beta \\
\hline gi|148222158 & MGC83560 protein & 160 & grancalcin, EF-hand calcium binding protein \\
\hline gi|148235491 & n-acetylneuraminate lyase $B$ & 103 & n-acetylneuraminate lyase B \\
\hline gi| 5690335 & CRM1/XPO1 protein & 80 & $\begin{array}{l}\text { CRM1/XPO1 (involved in export of proteins/RNA } \\
\text { from the nucleus) }\end{array}$ \\
\hline gi|47506906 & LOC398275 protein & 79 & ligase III, DNA, ATP-dependent \\
\hline gi|18029886 & DNA ligase IV & 62 & DNA ligase IV \\
\hline gi| 148222671 & $\begin{array}{l}\text { guanine nucleotide binding protein (G protein), } \\
\text { beta polypeptide } 1\end{array}$ & 60 & guanine nucleotide binding protein (G protein) \\
\hline gi|147904268 & hypothetical protein LOC100037235 & 48 & Thioredoxin \\
\hline gi|148222359 & MGC84047 protein & 130 & Debrin \\
\hline gi|148227164 & CDC-like kinase 2 & 81 & CDC-like kinase 2 \\
\hline gi|134024837 & LOC100049142 protein & 68 & heterogeneous nuclear ribonucleoprotein \\
\hline gi|147903659 & hypothetical protein LOC398863 & 63 & HSP70 \\
\hline gi|49523110 & LOC443723 protein & 62 & F-box protein 27 \\
\hline gi $\mid 148236420$ & ribosomal protein L19 & 60 & ribosomal protein L19 \\
\hline
\end{tabular}

Table 7.3 | Mascot result of proteins present in dsDNA and ssDNA sample after substraction of mock.

\begin{tabular}{|c|c|c|c|}
\hline GI Number & Protein Description (Mascot) & Score & Name (Blast) \\
\hline gi|55742495 & tubulin, beta & 7450 & tubulin \\
\hline gi|148228303 & imitation switch ISWI & 3496 & ISWI \\
\hline gi|11035016 & imitation switch ISWI & 3463 & ISWI \\
\hline gi| 147901418 & replication protein A (RPA) & 3979 & replication protein A (RPA) \\
\hline gi| 147903066 & hypothetical protein LOC496021 & 5524 & tubulin, alpha-like 3 \\
\hline gi|114795 & $\begin{array}{l}\text { "RecName: Full=Protein B4; AltName: } \\
\text { Full=Linker histone B4; AltName: } \\
\text { Full=Histone H1-like protein" }\end{array}$ & 2206 & B4 (maternal H1) \\
\hline gi|205360870 & $\begin{array}{l}\text { hypothetical protein LOC100189569 [Xenopus } \\
\text { laevis] }\end{array}$ & 1282 & $\mathrm{H} 4$ \\
\hline gi|218563708 & Williams syndrome transcription factor & 1245 & Williams syndrome TF \\
\hline gi|22653657 & $\begin{array}{l}\text { "RecName: Full=Bromodomain adjacent to } \\
\text { zinc finger domain protein } 1 \mathrm{~A} \text {; AltName: } \\
\text { Full=ATP-utilizing chromatin assembly and } \\
\text { remodeling factor } 1 \text {; Short=xACF1" }\end{array}$ & 1314 & ACF1 \\
\hline gi|148236805 & MGC80185 protein & 1510 & $\begin{array}{l}\text { proteasome (prosome, macropain) } 26 \mathrm{~S} \text { subunit, } \\
\text { ATPase, } 5\end{array}$ \\
\hline gi|28278099 & Psmc6 protein & 989 & $26 \mathrm{~S}$ protease regulatory subunit $\mathrm{S} 10 \mathrm{~B}$ \\
\hline gi| 148225238 & hypothetical protein LOC379596 & 867 & histone cluster $1, \mathrm{H} 2 \mathrm{am} \rightarrow \mathrm{H} 2 \mathrm{~A} . \mathrm{X}-\mathrm{F} 2$ \\
\hline gi| 148229573 & hypothetical protein LOC779385 & 813 & ribosomal protein $\mathrm{S} 4$ \\
\hline
\end{tabular}




\begin{tabular}{|c|c|c|c|}
\hline gi|147904062 & MGC81997 protein & 862 & histone cluster 1, H2aa $\rightarrow$ H2A.X-F1 \\
\hline gi|7305139 & histone cluster $1, \mathrm{H} 3 \mathrm{f}$ & 891 & H3 (H3.2) \\
\hline gi|122034 & $\begin{array}{l}\text { "RecName: Full=Histone H2B 1.2; } \\
\text { Short=H2B1.2" }\end{array}$ & 588 & $\mathrm{H} 2 \mathrm{~B}$ \\
\hline gi|58177865 & LOC733154 protein & 665 & ubiquitin carboxyl-terminal hydrolase L5 \\
\hline gi|148228702 & $\begin{array}{l}\text { X-ray repair complementing defective repair in } \\
\text { Chinese hamster cells } 5\end{array}$ & 580 & Xrrc5 \\
\hline gi|148232467 & $\begin{array}{l}\text { eukaryotic translation elongation factor } 1 \text { alpha } \\
2\end{array}$ & 480 & eukaryotic translation elongation factor 1 alpha 2 \\
\hline gi|147902910 & MGC82198 protein & 663 & histone H2A type 1 \\
\hline gi|148226262 & pl10 & 432 & $\begin{array}{l}\text { PL10- DEAD (Asp-Glu-Ala-Asp) box polypeptide } 3 \text { - } \\
\text { possible RNA helicase function }\end{array}$ \\
\hline gi|13507201 & cytoplasmic dynein intermediate chain & 519 & dynein \\
\hline gi|148235535 & proliferating cell nuclear antigen & 394 & PCNA \\
\hline gi|148222806 & hypothetical protein LOC398512 & 375 & topoisomerase (DNA) II \\
\hline gi|4502201 & ADP-ribosylation factor 1 & 420 & ADP-ribosylation factor 1 \\
\hline gi|52346108 & $\mathrm{H} 2 \mathrm{~A}$ histone family, member $\mathrm{Z}$ & 318 & H2A.Z \\
\hline gi|147902730 & $\begin{array}{l}\text { eukaryotic translation initiation factor XeIF- } \\
\text { 4AIII }\end{array}$ & 422 & eIF4A - a DEAD box RNA helicase \\
\hline gi|148230593 & $\begin{array}{l}\text { karyopherin alpha } 2 \text { (RAG cohort } 1 \text {, importin } \\
\text { alpha 1) }\end{array}$ & 319 & karyopherin - importin member \\
\hline gi|148226571 & histone-fold protein CHRAC17 & 403 & CHRAC17 (subunit of DNA polymerase epsilon) \\
\hline gi|54038660 & Unknown (protein for MGC:80886) & 260 & elongation factor 1-gamma (GST domain) \\
\hline gi|148230849 & phosphorylase phosphatase & 271 & phosphorylase phosphatase \\
\hline gi|393277 & protein phosphatase 1 -gamma 1 & 266 & protein phosphatase 1-gamma \\
\hline gi|147901906 & similar to histone deacetylase 2 & 220 & HDAC2 \\
\hline gi|83405638 & Unknown (protein for MGC:132046) & 270 & FACT complex subunit SPT16 \\
\hline gi|148230138 & hypothetical protein LOC414516 & 236 & SUB1 - gene encodes a Ca2+-binding protein \\
\hline gi|148224373 & ACTN1 protein & 203 & Actin native protein \\
\hline gi|148234437 & uroplakin $1 \mathrm{~B}$ & 291 & uroplakin (integral membrane protein) \\
\hline gi|148222828 & yeast RPD3 homologue & 249 & HDAC1-A (RPD3 homologue) \\
\hline gi|147903539 & $\begin{array}{l}\text { Protein phosphatase type } 1 \text { alpha, catalytic } \\
\text { subunit }\end{array}$ & 225 & Protein phosphatase \\
\hline gi|147906825 & actinin, alpha 3 & 177 & actin, alpha 3 \\
\hline gi|148226353 & hypothetical protein LOC494728 & 141 & uridine 5'-monophosphate synthase \\
\hline gi|28277248 & Dctn2-prov protein & 161 & Dynactin subunit 2 \\
\hline gi|147901825 & hypothetical protein LOC495270 & 132 & peptidylprolyl isomerase B (cyclophilin B) \\
\hline gi|148231827 & putative nuclease Mre11 & 127 & MRE11, double-strand break repair protein \\
\hline gi|147904965 & MGC80249 protein & 136 & small nuclear ribonucleoprotein $\mathrm{E}$ \\
\hline gi|148225246 & MGC 83587 protein & 102 & enabled homologue \\
\hline gi|148226266 & hypotheical protein LOC100049109 & 115 & RAE1 RNA export 1 homologue \\
\hline gi|147899655 & $\mathrm{C}$ protein & 101 & $\begin{array}{l}\text { heterogeneous nuclear ribonucleoprotein C - RNA } \\
\text { binding protein }\end{array}$ \\
\hline gi|148236889 & MGC84289 protein & 101 & phosphoribosylaminoimidazole carboxylase \\
\hline gi| 148226520 & Adenylate kinase 2 & 98 & Adenylate kinase 2 \\
\hline gi|148226152 & MGC83338 protein & 94 & eukaryotic translation initiation factor 3 subunit G-B \\
\hline gi|50603606 & Rbbp4 protein & 79 & Rbbp4 \\
\hline gi|963087 & phosphorylase phosphatase & 73 & phosphorylase phosphatase \\
\hline gi|28316404 & $\begin{array}{l}\text { structural maintenance of chromosomes protein } \\
6\end{array}$ & 71 & $\begin{array}{l}\text { SMC6 (structural maintenance of chromosomes } \\
\text { protein 6) }\end{array}$ \\
\hline gi|13274456 & $\begin{array}{l}\text { myelin PLP-related membrane protein DM } \\
\text { gamma1 }\end{array}$ & 54 & myelin PLP-related membrane protein DM gamma1 \\
\hline gi|148234996 & hypothetical protein LOC373791 & 54 & similar to chromosome $\mathrm{X}$ open reading frame 56 \\
\hline gi|50513045 & Dasra A & 90 & Dasra A \\
\hline gi|6630877 & fatvg & 81 & perilipin 2 \\
\hline gi|148231883 & mitochondrial carrier homologue 2 & 75 & mitochondrial carrier homologue 2 \\
\hline gi|147903317 & hypothetical protein LOC735209 & 68 & RAB32, member RAS oncogene family \\
\hline gi|148237374 & hypothetical protein LOC779418 & 66 & NFKB activating protein-like (NKAP) \\
\hline gi|147902061 & hypothetical protein LOC495019 & 65 & small nuclear ribonucleoprotein polypeptide $\mathrm{B}$ \\
\hline gi|147900412 & MGC80698 protein & 45 & $\begin{array}{l}\text { ras-related C } 3 \text { botulinum toxin substrate } 2 \text { (rho } \\
\text { family, small GTP binding protein Rac2) }\end{array}$ \\
\hline gi|148229072 & hypothetical protein LOC432141 & 44 & myosin, heavy chain 6 , cardiac muscle, alpha \\
\hline
\end{tabular}

